DEPARTMENT OF THE INTERIOR

Albert B. FALL, Secretary

United States Geological Survey

GeORge OTIS SMITh, Director

\title{
Bulletin 706
}

\section{THE IRON-ORE RESOURCES OF EUROPE}

BY

MAX ROESLER

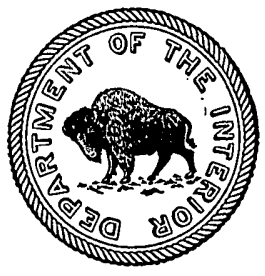

WASHINGTON

GOVERNMENT PRINTING OFFIOE 



\section{CONTENTS.}

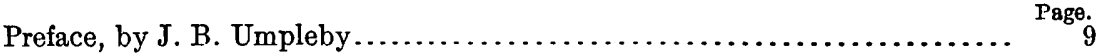

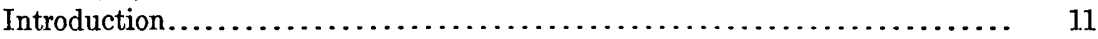

Object and scope of report $\ldots \ldots \ldots \ldots \ldots \ldots \ldots \ldots \ldots \ldots \ldots \ldots \ldots \ldots \ldots \ldots \ldots, 11$

Limitations of the work $\ldots \ldots \ldots \ldots \ldots \ldots \ldots \ldots \ldots \ldots \ldots \ldots \ldots \ldots, 11$

Definitions. ........................................... 12

Geology of iron-ore deposits................................ 13

The utilization of iron ores. . . . . . . . . . . . .

Acknowledgments.......................................... 16

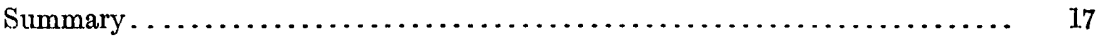

Geographic distribution of iron-ore deposits within the countries of new

Europe............................................... 17

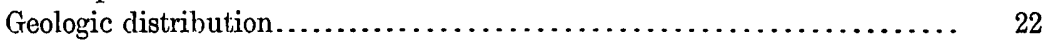

Production and consumption. . . . . . . . .

Comparison of continents................................. 29

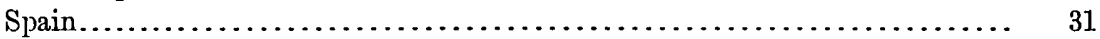

Distribution, character, and extent of the deposits............... 31

Cantabrian Cordillera.................................. $\quad 31$

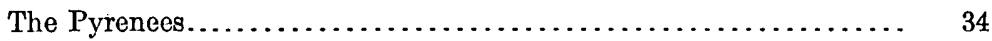

Ranges west of Ebro River ............................ $\quad 35$

Sierra Menera....................................... $\quad 36$

Sierra Guadalupe................................... 37

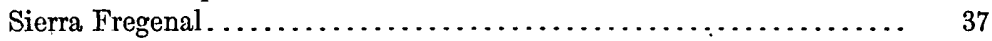

Sierra Morena....................................... 37

Ranges of the south coast................................ 39

Summary of the iron resources of Spain.................. 40

Production and consumption. ............................ 41

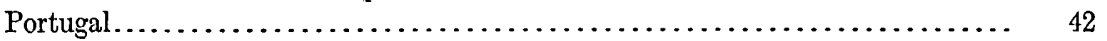

Distribution, character, and extent of the deposits................ 42

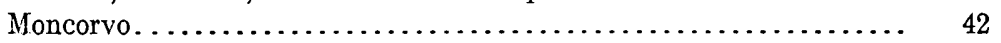

Porto de Moz......................................... 44

Serra dos Monges.................................... 44

São Thiago de Cacem and Odemira...................... 44

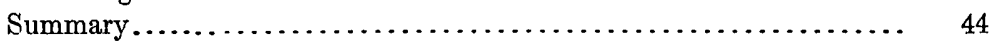

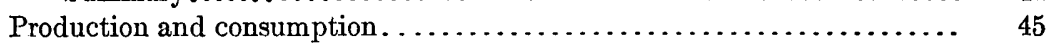

United Kingdom........................................... 45

Distribution, character, and extent of the deposits................. 45

Mesozoic ores........................................ 45

Carboniferous ores...................................... 48

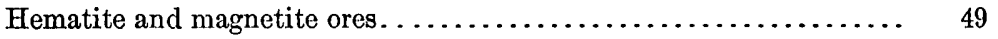

Miscellaneous deposits.................................. 51

Summary of iron resources of the United Kingdom............... 52

Production and consumption. .............................. 52

France.................................................. 55

Distribution, character, and extent of the deposits................ 55

Lorraine Basin......................................... 55

History . . . . . . . . . . .

Extent and character of the deposits.................. 60

Reserves.......................................... 63 
France-Continued.

Distribution, character, and extent of the deposits-Continued. Page.

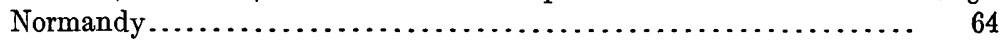

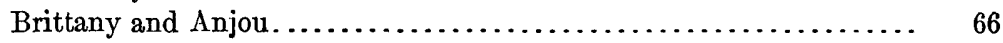

Pyrénées-Orientales..................................... $\quad 66$

Haute-Marne . ............................................. 67

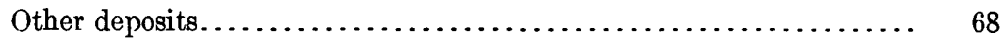

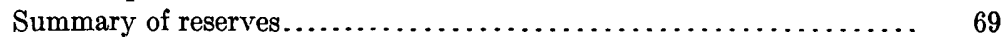

Production and consumption.................................... 69

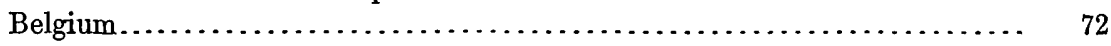

Distribution, character, and extent of the deposits................ 72

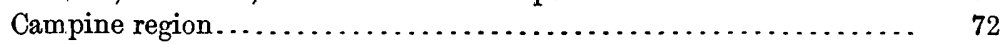

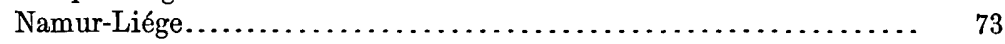

Production and consumption . . . . . . . . . . . . . .

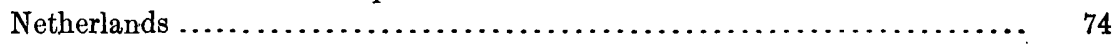

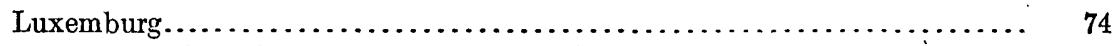

Distribution, character, and extent of the deposits ............... 74

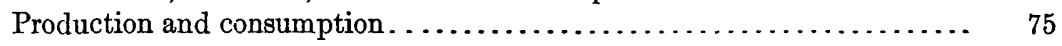

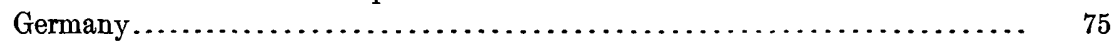

Distribution, character, and extent of the deposits................. 75

Saar Valley . . . . . . . . . . . .

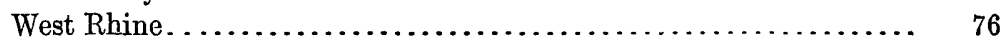

East Rhine........................................... $\quad 76$

Bergischer-Kalkberg district....................... $\quad 76$

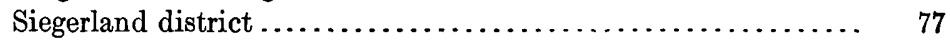

Lahn-Dill district.................................. $\quad 77$

Westerwald-Taunus-Vogelsberg district................. 78

Spessart....................................... 78

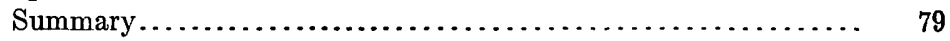

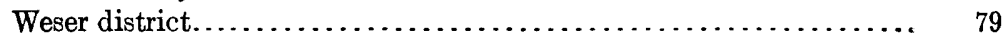

Salzgitter-Iselde region.............................. $\quad 79$

Harz Mountains .................................... 80

Kellerwald-Sauerland region. ........................ $\quad 80$

Lower Hesse. . . . . . . ........................... $\quad 80$

Bentheim-Ochtrup-Ottenstein region................... $\quad 80$

Teutoburger Wald and Wesergebirge areas................ 81

Oolitic ores.................................. 81

Summary of the Weser district. . . . . . . . . . . . . . . . $\quad 82$

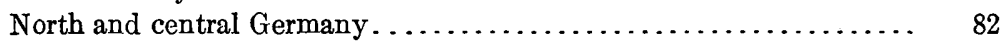

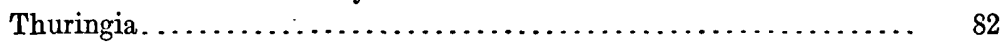

Bavaria and Württemberg................................... 83

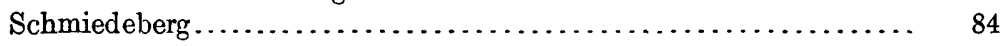

Summary of German iron reserves. ...................... 84

Production and consumption................................ 84

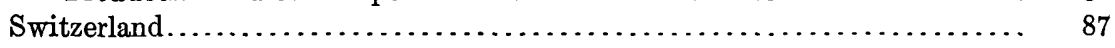

Distribution, character, and extent of the deposits.............. 87

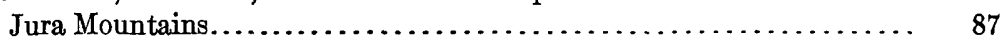

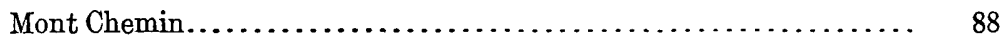

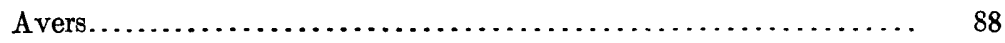

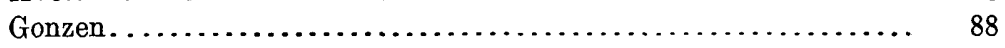

Chamoson and Erzegg-Planplatten........................ 88

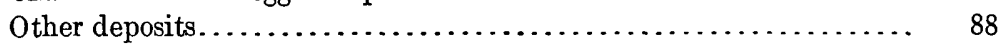

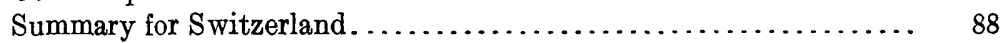

Production and consumption. ............................ 89 


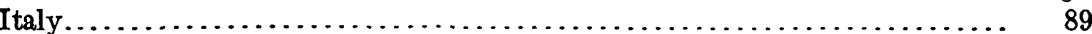

Distribution, character, and extent of the deposits................. 89

Elba................................................ 89

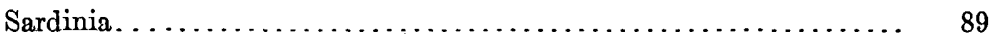

Val d'Aosta........................................... 90

Bergamo-Brescia. . . . . . . . . . . . . . . . .

Central Italy ........................................... 90

Miscellaneous........................................ 90

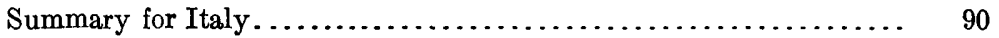

Production and consumption $\ldots \ldots \ldots \ldots \ldots \ldots \ldots \ldots \ldots \ldots \ldots \ldots, 91$

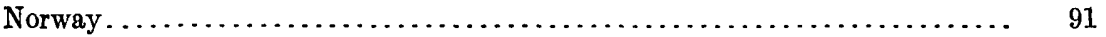

Distribution, character, and extent of the deposits................ 91

Concentrating ores of northern Norway.................... 92

Direct smelting ores of northern Norway.................. 93

Titaniferous ore.................................... 93

"Purple ore"

Southern Norway. ................................... 94

Summary for Norway $\ldots \ldots \ldots \ldots \ldots \ldots \ldots \ldots \ldots \ldots \ldots \ldots \ldots \ldots, 94$

Production and consumption. .............................. 94

Sweden.................................................. 94

Distribution, character, and extent of the deposits................. 94

Northern Sweden ..................................... 95

Central Sweden................................... 96

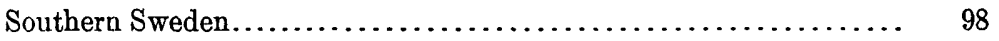

Summary for Sweden.................................. 99

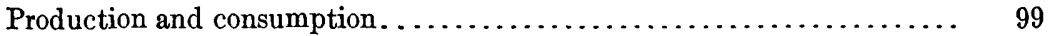

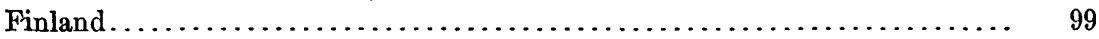

Distribution, character, and extent of the deposits................. 99

Production and consumption............................. 100

The Baltic States......................................... 101

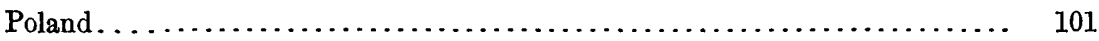

Distribution, character, and extent of the deposits............... 101

Location of mineral lands............................ 101

Triassic ores....................................... 101

Jurassic and bog ores................................. 101

Production and consumption. . ............................ 102

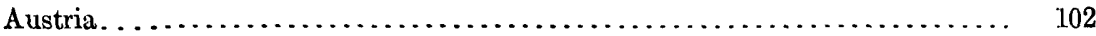

Distribution, character, and extent of the deposits............... 102

Production and consumption............................. 104

Czecho-Slovakia .............................................. 104

Distribution, character, and extent of the deposits.............. 104

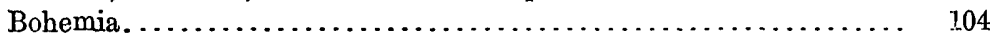

Moravia.......................................... 105

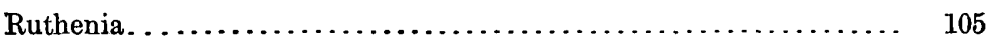

Summary of Czecho-Slovak reserves...................... 107

Production and consumption ................................. 107

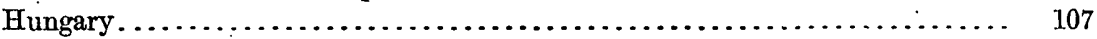

Production and consumption in the Austro-Hungarian Empire............ 107

The Balkan States. ........................................... 109

Bulgaria............................................ 109

Distribution, character, and extent of the deposits............. 109

Production and consumption........................ 110 
The Balkan States-Continued. Page.

Greece.............................................. $\quad 110$

Distribution, character, and extent of the deposits............. 110

Production and consumption. ........................... 111

Rumania.......................................... 111

Distribution, character, and extent of the deposits............ 111

Production and consumption........................... 113

Jugo-Slavia............................................... 113

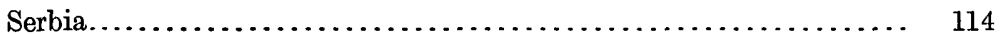

Croatia and Slavonia.................................... 114

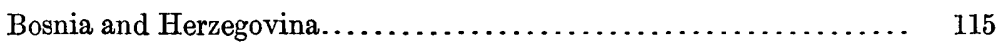

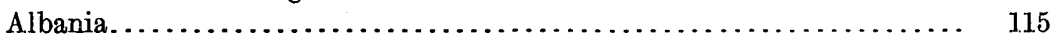

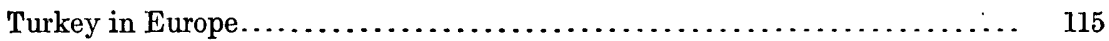

Russia...................................................... 116

Distribution, character, and extent of the deposits.............. 116

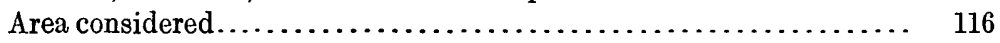

Northern Russia.................................. $\quad 116$

Central Russia....................................... 116

Southern Russia...................................... 117

Krivoi Rog........................................ 117

Donetz........................................ 118

Kosak Mogila...................................... 118

Kerch........................................ 118

Summary of southern Russia........................ $\quad 118$

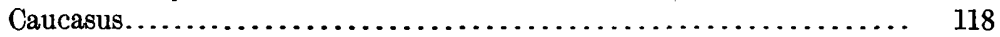

Ural Mountain region................................. 119

Bogoslovski estate................................ $\quad 119$

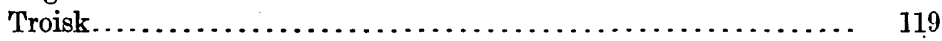

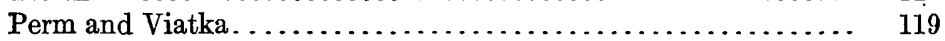

Gora Blagodat-Nizhni Tagilsk region................... 120

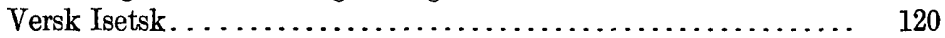

Alapaievsk district ............................. 120

Bilimbaievsk................................... 121

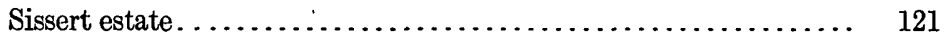

Ufalievski district................................. 121

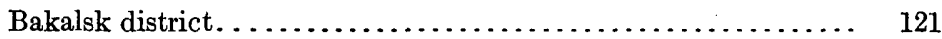

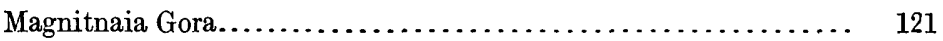

Summary of the Ural Mountain region.................. 122

Summary of Russia........................................ 122

Production and consumption. . . . . . . . . . . . . . . .

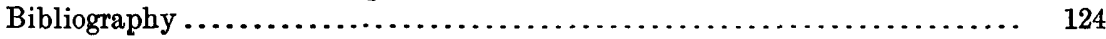

Index....................................................... 149

\section{ILLUSTRATIONS.}

Page.

I. Outline map of Europe showing reserves of iron in ore..........In pocket.

II. Outline map of Spain and Portugal showing reserves of iron in ore ........................................... In pocket.

III. Map showing the distribution of iron-ore deposits in Vizcaya Province, Spain ...................................... 34

IV. Outline map of the British Isles showing reserves of iron in ore 
Plate V. Map of the ironstone districts of Northampton and Lincoln, Eng-

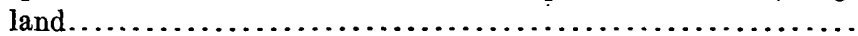

Page.

VI. Outline map of France, Belgium, and Netherlands showing reserves

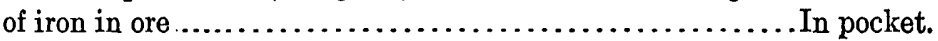

VII. Map of the Armorican peninsula, France, showing the distribution of oolitic iron ores in Normandy, Brittany, and Anjou.............

VIII. Outline map of Germany and Switzerland showing reserves of iron

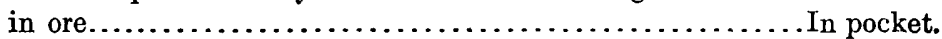

IX. Map showing distribution of the siderite deposits of Siegerland,

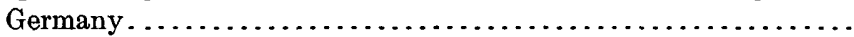

$\mathrm{X}$. Map showing distribution of iron-ore deposits in the Lahn-Dill district, Germany .....................................

XI. Outline map of Italy showing reserves of iron in ore.......... In pocket.

XII. Outline map of Norway, Sweden, and Denmark showing reserves of

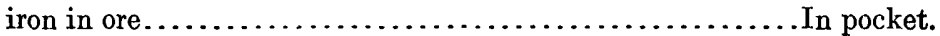

XIII. Outline map of Finland, Poland; west-central Russia, Esthonia, Latvia, and Lithuania showing reserves of iron in ore........In pocket.

XIV. Outline map of Austria, Hungary, and Czecho-Slovakia showing reserves of iron in ore...............................

XV. Map of Bohemia showing distribution of the principal iron-ore deposits. 104

XVI. Outline map of the Balkan States showing reserves of iron in ore

XVII. Outline map of northern Russia showing reserves of iron in ore

XVIII. Outline map of central Russia showing reserves of iron in ore...

In pocket.

XIX. Outline map of southern Russia showing reserves of iron in ore....

Fraure 1. Comparative chart showing the known, probable, possible, and total amounts of iron in the iron-ore deposits of several countries

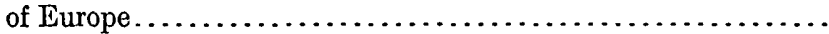

2. Chart exhibiting estimated proportions of Europe's iron inventories contained in the ore deposits of the several countries..........

3. Diagrams showing proportions of Europe's estimated iron reserves contained in ore deposits of different types and different geologic ages. ...............................................

4. Chart showing amounts of iron ore produced and consumed in Europe as a whole and in the several European countries in 1913.

5. Chart showing proportion of total iron ore consumed supplied by net imports or proportion of total iron ore produced going to net exports in 1913 for several countries in Europe..............

6. Chart showing proportional contributions of the several countries to the total amount of iron ore produced in Europe in 1913, and the proportions of potential output under the political sub-

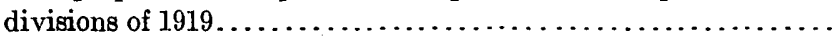

7. Map showing deposits of iron ore in the Sierra Menera, Spain.....

8. Ratio chart showing iron ore produced during five-year periods ending 1875 to 1910 in Spain, Europe, the United States, and the world.

9. Map showing deposits of iron ore in Portugal

10. Map of the Cleveland iron-ore district, England.................

11. Map showing distribution of the hematite deposits of Cumberland

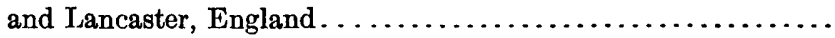


Figdre 12. Ratio chart showing iron ore produced during five-year periods ending 1875 to 1910 in the United Kingdom, Europe, the United States, and the world..................................

13. Chart showing iron ore produced, imported, and consumed in the United Kingdom, 1873-1917...........................

14. Ratio chart showing iron ore produced annually in the United Kingdom, the German Customs Union, and the United States, 1873-1917.

Page.

15. Ratio chart showing iron ore produced annually in Lorraine Annexée, French Lorraine, and Luxemburg, 1871-1913...........

16. Ratio chart showing iron ore produced annually in the minette basin of Lorraine, 1871-1913, and in the Lake Superior district, 1871-1917.

17. Sketch map of the minette iron-ore basin showing the position of the deposits, the Franco-German boundary of 1870, and ironmining concessions in the vicinity of Nancy ...............

18. Sketch map showing distribution of iron mines in the Province of Pyrénées-Orientales, France..........................

19. Ratio chart showing iron ore produced during five-year periods ending 1875 to 1910 in France, Europe, the United States, and the world.

20. Ratio chart showing iron ore produced annually in France and in the Department of Meurthe-et-Moselle, 1894-1913.

21. Ratio chart showing iron ore exported and imported annually by France, 1894-1913

22. Sketch map showing areas of developed iron ore in the Franconian Alps, Bavaria.

23. Ratio chart showing iron ore produced during five-year periods ending 1875 to 1910 in the German Customs Union, Europe, the United States, and the world.

24. Diagrams showing iron ore produced annually in the German Customs Union, 1908-1913, and the quantities and proportions contributed by Luxemburg, Lorraine Annexee, and German mines outside of Lorraine...............................

25. Map of iron-ore fields of Sydvaranger, Norway ...............

26. Sketch map showing distribution of iron-ore deposits of northern Sweden

27. Map of the iron-ore field at Grängesberg, central Sweden.........

28. Ratio chart showing iron ore produced during five-year periods ending 1875 to 1910 in Sweden, Europe, the United States, and the world.

29. Map showing deposits of iron ore in the vicinity of Erzberg, Styria, Austria. .........................................

30. Map showing deposits of iron ore in the Szepes-Gömör district, Ruthenia, Czecho-Slovakia..........................

31. Ratio chart showing iron ore produced during five-year periods ending 1875 to 1910 in the Austro-Hungarian Empire, Austria, Hungary, Europe, the United States, and the world............

32. Map showing deposits of iron ore in the Banat and Hunyad districts, Rumania.

33. Ratio chart showing iron ore produced during five-year periods ending 1875-1910 in Russia, Europe, the United States, and the world. 


\section{PREFACE.}

\section{By Joseph B. Umpleby.}

Most of the commercially available iron-ore deposits of the world occur on one or the other side of the North Atlantic. The location, extent, and character of our own deposits are well known to those who are interested in the American iron industry, but comparable information in English concerning the deposits of Europe is not available. We hold undisputed first place in the production of iron and steel, and our furnaces and mills are capable of sustaining a large export trade, but it is not enough to have intimate knowledge of our domestic deposits alone: we must know also the extent and the possible development of those foreign deposits with which our own must compete in international trade. A wealth of literature has been published on the iron-ore deposits of Europe, but it is the product of many writers, each occupying his individual viewpoint, it is printed in many languages, and much of it appears in publications that are not found in most libraries. The author of this report has undertaken to reduce this large and diverse record to nearly common scale or proportions and to present its content as briefly as possible to the American reader.

The work of determining the location and extent of foreign mineral deposits was originally undertaken as part of a comprehensive survey of the world's mineral wealth for the guidance of the American Commission to Negotiate Peace, but now that this purpose has been served the work is being continued as an aid to our foreign trade and a guide in the most rational development of our domestic resources.

The results of the work of the Geological Survey on foreign mineral deposits will be published in the form of an atlas of commercial geology, containing maps showing the distribution of the economic minerals, accompanied by brief texts, and in bulletins, such as this one, giving more detailed information on a single mineral, together with a working bibliography. As iron resources are of paramount importance to industrial nations another bulletin, ${ }^{1}$ focused on the industrial aspects of the deposits of iron ore in central Europe, has also been issued by the Geological Survey. That bulletin may serve as a companion volume to this one, which deals primarily with the deposits themselves.

1 Brooks, A. H., and La Croix, M. F., The iron and associated industries of Lorraine, the Sarre district, Luxemburg, and Belgium: U. S. Geol. Survey Bull. 703, 1921. 



\title{
THE IRON-ORE RESOURCES OF EUROPE.
}

\author{
By Max Roester.
}

\section{INTRODUCTION.}

\section{OBJECT AND SCOPE OF REPORT.}

This bulletin gives a summary of the facts concerning the deposits of iron ore in Europe and estimates of the quantities of ore and of iron they contain. It reports no original research work; it is simply the result of a study of the work of many writers and is an attempt to reduce the variant products of that work to common values. The geographic review of the deposits is preceded by a brief sketch of the nature and geology of iron-ore deposits in general and a few notes on the methods of utilizing the ores. The geologic distribution of the deposits is considered, and the more extensive deposits are described. The economic value of the iron ore in the several countries of Europe is shown by the statistics of production and consumption.

Unfortunately, the political boundaries of many European States are still uncertain, and some váluable ore deposits are not yet definitely allocated to a particular political unit. Perhaps undue emphasis is given to the deposits of Germany and France, but the political conditions from which this study arose make this emphasis natural, and it is probably in accord with the present popular interest.

\section{LIMITATIONS OF THE WORK.}

The value of the results of any study depends directly on the accuracy of the information on which the study is based. The authors of numerous articles consulted were men who occupied different viewpoints, and perhaps most of them were geologists, who had little interest in the economic value or development of the deposits. On the other hand, some of the articles were written by engineers, whose work was impaired by lack of geologic knowledge.

A notable limitation on the work was that imposed by the languages in which the articles were written. Originals written in French, German, or Spanish were consulted directly, but those written in the Slavonic languages were available only in translations or abstracts.

A further limitation is inherent in the subject. The quantity of ore already mined from the average deposit can be easily calculated, and the quantity of ore that is probably minable can be estimated 
with fair assurance as to accuracy, for it is dependent on definite limitations; but the quantity that is possibly available is in only a few deposits susceptible of rigid definition, and personal judgment must enter largely into any estimate of it.

\section{DEFINITIONS.}

The term "ore" as here used means an aggregate of iron-bearing minerals that is now commercially valuable or that may reasonably be expected to be valuable in time of need. The experience of the last few years with so-called "war" minerals has shown that material which in normal times would not be considered ore can be utilized in time of stress.

In classifying material as ore the means and cost of transportation have been ignored. On the other hand, technologic difficulties or values, such as the inherent difficulty of mining thin seams or of mining at great depth and, so far as possible, the metallurgic value of the product, have been considered.

In order that the estimates given might be made reasonably uniform in value certain limits were fixed to the definitions of "known," "probable," and "possible" ore-terms that are used throughout this bulletin.

"Known" ore is developed material that is or can be profitably mined now.

"Probable" ore is material that may probably be mined hereafter, the probability being based on present standards in mining and metallurgy and on geologic indications as to the continuity of the deposit.

"Possible" ore includes ore of present commercial grade which lies so deep that it is not now available but which a slight improvement in mining methods or an increase in price would render available; ore which is of lower grade than that now used but so near to that of present grade that it will probably be used in a not very distant future; ore which is used chiefly as flux; and ore which is chemically not fit for use in present metallurgic practice but that may be used in the future, such as titaniferous ore or ore containing a large quantity of silica. The figures showing "possible" ore must be used with caution, because even though they are the result of careful consideration they involve many assumptions and are subject to many errors in judgment. It is hoped, however, that they have comparative value; at least they have all been evaluated with equal rating.

In this grouping consideration has been given to industrial changes, such as the constant decrease in the production of ore from the English coal measures and the increase in the production of ore from the Bavarian and Swabian Alps.

Except where otherwise stated the unit employed is the metric ton. 


\section{GEOLOGY OF IRON-ORE DEPOSITS.}

As the valuation of iron-ore deposits depends largely on the interpretation of geologic data a brief statement of the salient features of the geology of the deposits is necessary to enable the reader to understand the descriptions and to put him in a position to criticize the conclusions presented.

Iron occurs in almost all the rocks that are exposed at the earth's surface. According to F. W. Clarke ${ }^{2}$ the lithosphere contains 4.5 per cent of iron. This iron is scattered through the rocks in innumerable complex minerals-silicates, carbonates, sulphides, oxides, etc.-but in order to form an ore body the iron in these minerals must be concentrated so that their iron content is from 4 to 14 times as great as that in the earth's crust in general.

The minerals of which the great bulk of the world's iron-ore deposits is composed are comparatively simple. They are:

Oxides....... $\left\{\begin{array}{l}\mathrm{Fe}_{2} \mathrm{O}_{3} \cdot \mathrm{FeO} . \text { Magnetite. } \\ \mathrm{Fe}_{2} \mathrm{O}_{3} \ldots \ldots \text {. Hematite. } \\ \mathrm{Fe}_{2} \mathrm{O}_{3} \cdot \mathrm{H}_{2} \mathrm{O} \text {. Goethite (crystalline), limonite (amorphous). }\end{array}\right.$

Carbonate.......FeO. $\mathrm{CO}_{2} \ldots$. Siderite.

Complex silicates......... Chamosite, thuringite, and glauconite.

The field work of many geologists and the laboratory work of R. B. Sosman and J. C. Hostetter, ${ }^{3}$ E. Posnjak and H. E. Merwin, ${ }^{4}$ and others have shown that the iron oxides rarely occur in pure form in nature. They form series containing varying amounts of $\mathrm{Fe}_{2} \mathrm{O}_{3}, \mathrm{FeO}$, and $\mathrm{H}_{2} \mathrm{O}$ and may be grouped as follows:

Magnetite-hematite.......................... $\mathrm{Fe}_{2} \mathrm{O}_{3} \cdot \mathrm{FeO}-\mathrm{Fe}_{2} \mathrm{O}_{3}$

Hematite-goethite............................ $\mathrm{Fe}_{2} \mathrm{O}_{3}-\mathrm{Fe}_{2} \mathrm{O}_{3} \mathrm{H}_{2} \mathrm{O}$

Brown ores........................... $\mathrm{Fe}_{2} \mathrm{O}_{3} \cdot \mathrm{H}_{2} \mathrm{O}-\mathrm{Fe}_{2} \mathrm{O}_{3} \pm \mathrm{H}_{2} \mathrm{O}$

Siderite is also frequently found as an impure carbonate in which iron is replaced by calcium, magnesium, or manganese.

Chamosite, thuringite, and glauconite have aided in the formation of some of the sedimentary deposits of iron ore but in themselves form relatively few commercially valuable deposits.

If arranged according to mode of formation deposits of iron ore can be grouped in two major classes-(1) concentrations formed by deepseated agencies and (2) concentrations formed by surficial agencies. The mineralogy and to some extent the form of the deposits of these two classes are essentially different.

1. The agencies that form deposits of the first class are igneous, but the temperatures and pressures involved in their formation may

\footnotetext{
- Clarke, F. W., The data of geochemistry, 4th ed.: U. S. Geol. Survey Bull. 695, p. 35, 1920.

- Sosman, R. B., and Hostetter, J. C., The ferrous iron content and magnetic susceptibility of some artificial and natural oxides of iron: Am. Inst. Min. Eng. Trans., vol. 58, pp. 409-433, 1917; Zonal growth in hematite and its bearing on the origin of certain iron ores: Idem, pp. 433-444.

4 Posnjak, E., and Merwin, H. E., The hydrated ferric oxides: Am. Jour. Sci., 4th ser., vol. 47, pp. 311-348, May, 1919.
} 
range from those of molten magmas to those found at the earth's surface. Two types of deposits of this class are of common occurrence(a) deposits associated with gabbros and $(b)$ deposits associated with granitic rocks.

(a) The ores associated with gabbros carry iron mainly as magnetite, and most of them contain considerable titanium, which occurs as ilmenite. The ore bodies generally form integral parts of the intrusive masses in which they occur and are regarded as segregations within the igneous magma.

(b) The ores associated with granitic rocks contain magnetite as their only essential iron mineral if they were formed at great depth, but they may contain any mineral of the magnetite-hematite series if they were formed at moderate depth. If they include titanium it occurs as titanite, not as ilmenite. In deposits formed at great depth the relations between the ore bodies and the parent granite or allied rock are commonly very like those of the ore masses associated with the gabbros, but in deposits formed at moderate depth the relations are generally very different. In ores formed at great depth the iron minerals are apparently segregated as a result of magmatic differentiation in place, whereas in those formed at less depth, under pressure permitting tenuous or mobile constituents to escape from the magma, the iron is collected by and carried with these constituents to be later segregated in veins or in deposits that replace limestones or other rocks. Most iron ores thus formed by replacement occur close to the borders of the invading igneous masses. Throughout the western part of the United States limestones that were invaded by the magmas of monzonites appear to have been particularly susceptible to replacement by minerals carried by metalliferous solutions that obviously originated within the monzonitic igneous masses, and here there are many "contact" deposits of magnetite. Elsewhere, as along the south coast of the Province of Santiago, in Cuba, igneous rocks have been replaced by iron ore through the agency of solutions connected in origin with rocks related to granite.

2. The iron-ore deposits of the second major class - the concentrations formed by surficial agencies-are of several different types:

(a) Residual deposits formed by the alteration and concentration of iron minerals very nearly in place; including lateritic deposits formed by the removal of material other than iron, and by the alteration of the iron minerals to amorphous or crystalline ferric hydrate, with more or less adsorbed water; also gossans of sulphide ore bodies formed by oxidation of the sulphides.

(b) Bog ores formed by the deposition of ferric hydrate and ferrous carbonate from surface solutions. The iron in these deposits is precipitated from solutions by organic matter or by the evaporation of its solvent. 
Where oxidizing iron-bearing solutions come into contact with rocks rich in iron sulphide some of the iron-ore material may obviously be formed practically in place, so that deposits of types $a$ and $b$ may grade into each other.

(c) Sedimentary ores formed by weathering and subaqueous depositjon. Some of these deposits, such as magnetite beach sands, may be of purely mechanical origin, but more frequently chemical agencies form subaqueous deposits of iron silicates or carbonates, or precipitate iron from solutions as ferric hydrate.

(d) Replacement and vein deposits formed by iron-bearing waters of surficial origin in the course of artesian circulation. Deposits of this type are so similar to the deposits of siderite formed by the cooler solutions of igneous origin that the two can be discriminated only with difficulty. The ore minerals are carbonates and more or less ferric hydrate.

The following classification, based on the above distinctions, will be used in describing the deposits here considered:

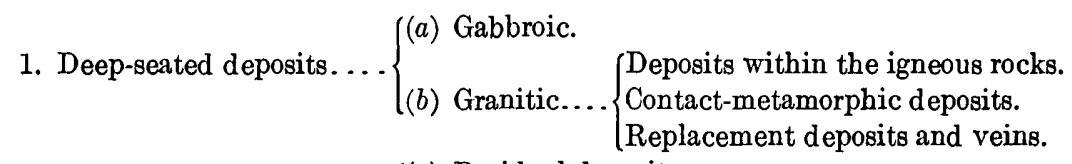

2. Surficial deposits........ $\left\{\begin{array}{l}(a) \text { Bog ores. } \\ \text { (c) Sedimentary }\end{array}\right.$

$\{$ (c) Sedimentary deposits.

(d) Replacement deposits and veins.

This classification takes no account of the complex metamorphic agencies that alter many deposits and conceal evidence of genesis. In many places dynamic metamorphism has brought about changes that have made ore bodies from leaner aggregates of iron minerals. Replacement, solution, and redeposition act upon ore bodies to enrich or to impoverish them. The result of these processes may be an ore body whose history is exceedingly complex. Such ore bodies will be classified so far as possible according to their original mode of deposition.

\section{THE UTILIZATION OF IRON ORES.}

In considering statistics of the consumption of the iron ore it must be remembered that the industry involves other factors than the possession of iron ore. Minor factors are the availability of metals used for making alloy steel and of flux for smelting. The dominant factor in the present state of the industry, however, is possession of coal suitable for making coke of metallurgic grade. The importance of this factor is shown by the fact that in order to smelt 42,000,000 metric tons of Lorraine ore and to convert the 
resultant pig iron to products of finished steel, coal and coke would be required equivalent to at least $55,000,000$ metric tons of coal. ${ }^{5}$

According to statistics published by the American Iron and Steel Institute, 44,431,905 short tons of coke was used in the United States in 1916 to produce $39,434,797$ long tons of pig iron. The weight of fuel needed to convert iron ore to pig iron is not greatly in excess of the weight of ore utilized, so that if the making of pig iron were the ultimate end sought it might be almost as economical and efficient to ship coal to an ore-mining district as to ship ore to a coal-mining district. But the making of pig iron is only the first step in the industry. Steel and manufactured products must be made from the pig iron, and each step requires fuel. For that reason the centers of the iron and steel industries are in or near coal-mining districts, the three largest iron and steel centers of the world being connected with the Appalachian, the British, and the Rhenish coal fields.

The use of charcoal in the iron industry is steadily decreasing and the use of electro-metallurgy is as steadily increasing. The employment of processes that permit the utilization of coals of lower grade than those heretofore used for the manufacture of metallurgic coke will greatly enlarge the territory suitable for the development of the iron industry.

The principal raw materials required for producing pig iron are ore as a source of metal, coke as fuel, and limestone as furnace flux; but as limestone is, in general, much more widely distributed than uron ore and coking coal the ordinary prime necessities for the maintenance of an iron industry consist of ore of commercial grade and of coal suitable for making coke. Nearly all the world's iron smelting is done in or near districts where coking coal is mined.

The coal equivalent of the coke employed in smelting weighs less than the ore that goes into the furnace, but the operations involved in the production and fabrication of finished steel require considerably more coal than ore. The economics of the iron industry, epitomized in the well-known saying "ore goes to coal," are illustrated by Sweden and Spain, which, though possessing great reserves of rich iron ore, have iron industries that are almost negligible and send millions of tons of ore to countries that are better supplied with fuel.

\section{ACKNOWLEDGMENTS.}

The present paper is the outgrowth of a report compiled by the United States Geological Survey for use at the Peace Conference and not originally intended for publication. As it is believed, however, that the information is of general interest it has been brought together here in compact form. The discussions concerning the

\footnotetext{
${ }^{6}$ Spencer, A. C., in Smith, G. O., and others, The strategy of minerals, p. 133, 1919.
} 
individual deposits are too brief for the student who desires great detail, but footnote references to the publications examined and the bibliography will, it is hoped, lead readily to the sources of the information. By far the greater part of the material consulted consists of the more readily available publications of governmental surveys and scientific societies and of articles in the technical press. The results of the study of the world's iron-ore resources compiled for the International Geological Congress in 1910 were of the highest value and offered a firm and comprehensive base for the present study. Next in value was the excellent and complete annotated bibliography published in the Journal of the Iron and Steel Institute of Great Britain, which pointed the way to many sources of information that would otherwise have been overlooked.

The work was done under the direction of J. B. Umpleby, who was at all times ready with helpful suggestions. The notes of Eleanora F. Bliss on consumption and production were freely used. The author feels particularly grateful to A. C. Spencer for helpful criticisms and suggestions and for the readiness with which he made available his vast store of unpublished information.

\section{SUMMARY.}

\section{GEOGRAPHIC DISTRIBUTION OF IRON-ORE DEPOSITS WITHIN THE COUNTRIES OF NEW EUROPE.}

Though the Peace Conference rearranged the political divisions of Europe, racial antagonisms, class struggles, and divergent economic demands or needs promise to make still further rearrangement necessary. Enough information is available, however, to show the new political relations of the larger deposits of iron ore in Europe. The political divisions used in this study are shown on Plate I (in pocket). The principal changes in the ownership of iron-ore resources can be summarized very briefly.

The part of the minette ore basin that lies in Lorraine Annexée has been returned to France. Of the German bog ores, the part estimated for Posen has been allotted to Poland, as has also the sniall deposit of Triassic ores in the part of Silesia whose ultimate possession remains to be determined by a plebiscite. The small deposits near Krakow, in Galicia, also fall to Poland.

The iron ores of Bohemia and Moravia, as well as those of the Szepes-Gömör district, which lies in the Ruthenian country, on the southern slopes of the Karpathians, have been allotted to CzechoSlovakia. The deposit in the Vares district, in Bosnia, has been allotted to Jugo-Slavia. The deposits in eastern and southeastern Hungary (those of Banat and of Hunyad being the only extensive ones) are regarded as belonging to a greater Rumania.

$15945^{\circ}-21-$ Bull. $706 \_2$ 
Poland and Finland, parts of old Russia, are regarded as independent. The uncertainty in regard to Poland's eastern frontier and the rearrangement of the Baltic States does not affect the allocation of the iron reserves in that region, because the unallotted territory contains no ores valuable enough to be reported. The rest of old Russia has been divided geographically into the Ural Mountain region, central Russia, southern Russia (which includes the Crimea and is largely Ukrainian), and the Caucasus.

The following table shows, in quantities and percentages, the geographic distribution of the iron in the iron-ore deposits of Europe, and the accompanying chart (fig. 1) shows in graphic form the distribution by percentages.

Iron reserves of Europe.

[Millions of metric tons.]

\begin{tabular}{|c|c|c|c|c|c|}
\hline & Known. & Probable. & Possible. & Total. & Per cent. \\
\hline 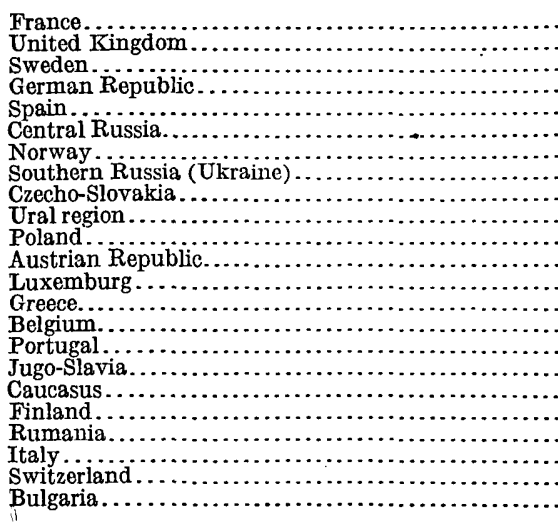 & $\begin{array}{r}1,790.0 \\
317.5 \\
442.9 \\
255.6 \\
353.1 \\
140.0 \\
85.8 \\
71.0 \\
22.3 \\
52.3 \\
11.2 \\
76.7 \\
60.0 \\
18.0 \\
2.5 \\
8.2 \\
9.5 \\
6.2 \\
3.6 \\
2.5 \\
5.5 \\
1.2 \\
\end{array}$ & $\begin{array}{r}1,053.6 \\
464.3 \\
376.1 \\
207.4 \\
116.3 \\
180.0 \\
56.4 \\
131.0 \\
84.8 \\
60.8 \\
50.6 \\
9.5 \\
21.0 \\
18.0 \\
14.1 \\
16.2 \\
8.0 \\
6.2 \\
11.4 \\
8.5 \\
3.3 \\
\end{array}$ & $\begin{array}{r}1,526.0 \\
1,472.3 \\
729.6 \\
911.7 \\
148.9 \\
204.1 \\
330.1 \\
142.0 \\
58.6 \\
47.8 \\
69.2 \\
30.0 \\
\ldots \ldots .5 \\
22.5 \\
23.2 \\
12.5 \\
16.0 \\
18.6 \\
1.9 \\
4.0 \\
\ldots \ldots \ldots \\
\ldots .2 .2 \\
\ldots \ldots \ldots . . \\
\end{array}$ & $\begin{array}{r}4,369.6 \\
2,254.1 \\
1,548.6 \\
1,374.7 \\
618.3 \\
524.1 \\
472.3 \\
344.0 \\
165.7 \\
160.9 \\
131.0 \\
116.2 \\
81.0 \\
58.5 \\
39.8 \\
36.9 \\
33.5 \\
31.0 \\
16.9 \\
15.0 \\
8.8 \\
3.4 \\
.7 \\
\end{array}$ & $\begin{array}{r}35.2 \\
18.2 \\
12.5 \\
11.1 \\
5.0 \\
4.2 \\
3.8 \\
2.8 \\
1.3 \\
1.3 \\
1.1 \\
.9 \\
.7 \\
.5 \\
.3 \\
.3\end{array}$ \\
\hline & $3,735.6$ & $2,898.2$ & $5,771.2$ & $12,405.0$ & 100.0 \\
\hline
\end{tabular}

Figure 2, which is drawn to scale to facilitate visual comparison, shows the iron content of the ore in the reserves of the principal countries of Europe. The figure is based on statistics that are not of equal accuracy throughout and requires some explanation.

France has the largest reserves. She stands so clearly above the other countries of Europe that there is no question of her holding first place.

The United Kingdom is ahead of Sweden in the iron content of her total reserves. Very good information is available in regard to the iron-ore deposits of both countries. The Swedish reserve is preponderantly magnetite of high grade; the British reserve is carbonate and hematite of much lower grade. The "known" and "probable" ore can be estimated for both countries with considerable assurance as to the accuracy of the figures. The estimation of the "possible" reserves involves decisions on matters that are open to 


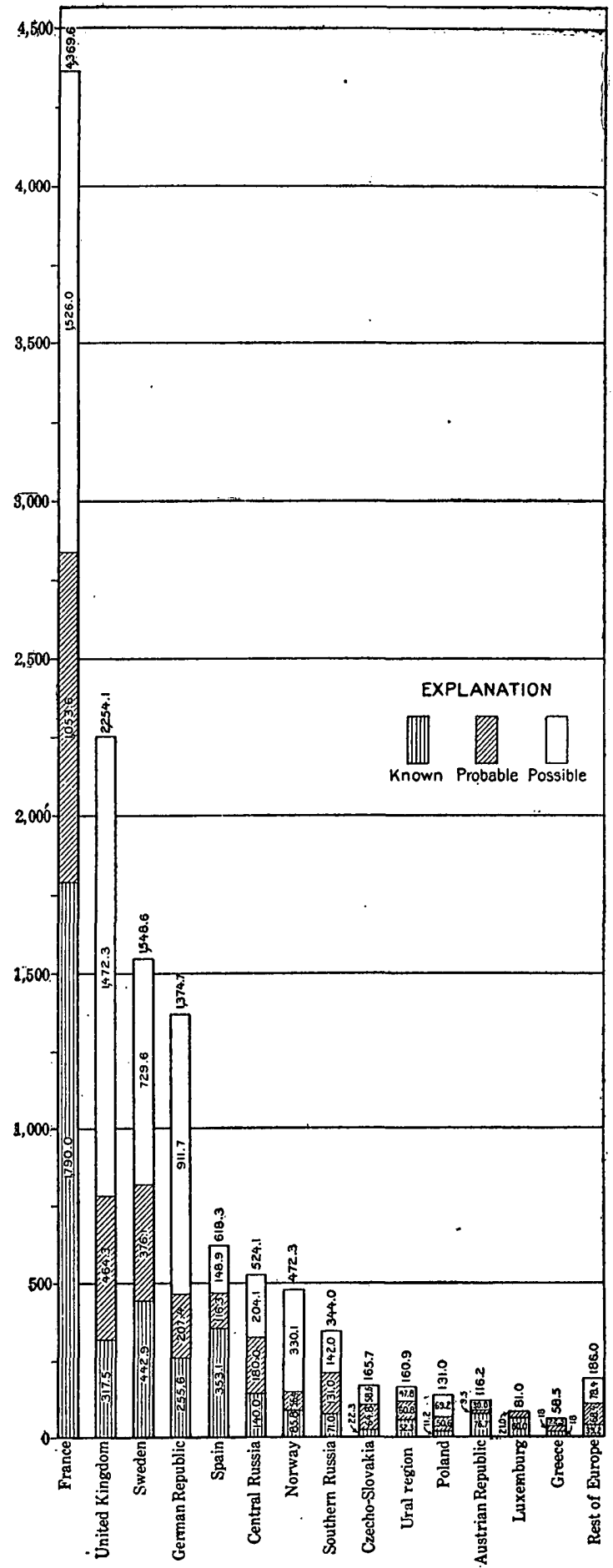

EIGURE 1.-Comparative chart showing the estimated known, probable, possible, and total amounts o? iron in the iron-ore deposits of several countries of Europe. 
THE IRON-ORE RESOURCES OF EUROPE.

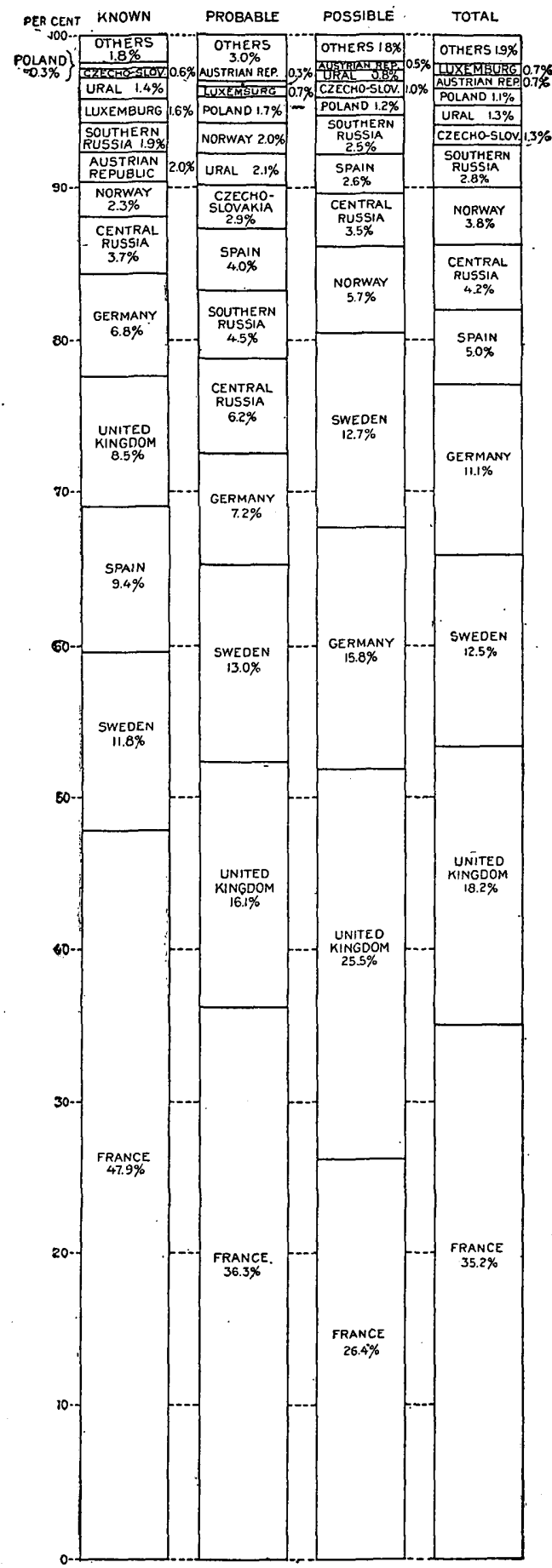

FIGURE 2.-Chart exhibiting estimated proportions of Europe's iron inventories contained in the ore deposits of the several countries. 
controversy and must depend on the attitude of the person making the estimate. The quantity of ore in Sweden that can be put in this class depends on the depth to which mining can be carried in ores that, under normal conditions, are bound to have a ready market. The estimate for Great Britain is complicated by the fact that much of the ore there can not compete with foreign ores, even if it may be readily minable, so that in spite of the enormous British reserves the use of imported ores in England is increasing and the production of domestic ores is decreasing. The enormous reserves of iron that English geologists have estimated as in the ground in Great Britain are undoubtedly there, but they will probably not be used in a quantity greater than that shown by the figure given under "possible" reserves, and even that figure may be too large.

The fourth rank should go to Germany. The estimates of her ore reserves have been carefully worked out and are acceptable for "known" and "probable" ore. The accuracy of the large figure for the "possible" reserve depends on the future of the Salzgitter-Iselde and Württemberg-Bavarian fields. Production in both these districts was steadily increasing before 1914. Germany has shown her capacity to use her resources thoroughly enough to justify the conclusion that she will continue to use them in spite of the native pessimists who can foresee her future as only that of an agrarian State.

Spain stands fifth. Her measured and available reserve is next to that of Sweden, but difficulties and expenses of transportation, which have been left out of consideration in calculating her reserve, make it questionable whether her entire reserve will be mined.

Central Russia is sixth in quantity of iron ore. The present outlook is that political conditions will delay the normal development of this field.

Norway has a large quantity of concentrating ore that has not been so useful in the past as it may be in the future.

Southern Russia, in its ore in Krivoi Rog and Kerch, has a valuable reserve, and future development may give her a higher place than the eighth, her present rank.

Czecho-Slovakia, the Ural Mountain region, the Austrian Republic, and Luxemburg have nearly equal amounts of known ore, and Poland has a reserve of unknown value. All these may be put in the same class so far as reserves of iron ore are concerned. The principal reserves in Czecho-Slovakia are the oolitic silicate and brown ores of central Bohemia and the spathic ores of the SzepesGömör district. The possession of these reserves and of those in that part of the Dombrova coal basin that lies in former Austrian Silesia places Czecho-Slovakia in a strong position to establish and maintain an iron industry. 
The Ural Mountain region contains ore deposits of many different types, and further investigation may discover deposits that have not been included in the present estimate.

The Austrian Republic has an excellent reserve in the spathic ores of Styria and Carinthia, but its utilization is more or less dependent on foreign coal.

The Luxemburg part of the minette basin constitutes a fully explored and valuable reserve, but it is a problem how completely it will be exhausted. Only about a third of the reserve has been assigned to the "probable" class.

The reserves of Poland are composed largely of brown ores that in a critical scheme of classification lie close to the line that separates available from unavailable ores. Slight changes in technology may increase their value; or a slight decrease in the cost of competing ores may make them valueless.

The chromiferous ores of Greece will be a desirable addition to the European supply of iron ore for some time to come.

Belgium, Portugal, Jugo-Slavia, the Caucasus, Finland, Rumania, Italy, Switzerland, and Bulgaria all have small reserves. Turkey in Europe contains some ore; Holland, Denmark, and the Baltic States contain practically none.

\section{GEOLOGIC DISTRIBUTION.}

Eckel ${ }^{8}$ classifies the iron ores of Europe in regard to type as follows:

Types of iron ore in Europe.

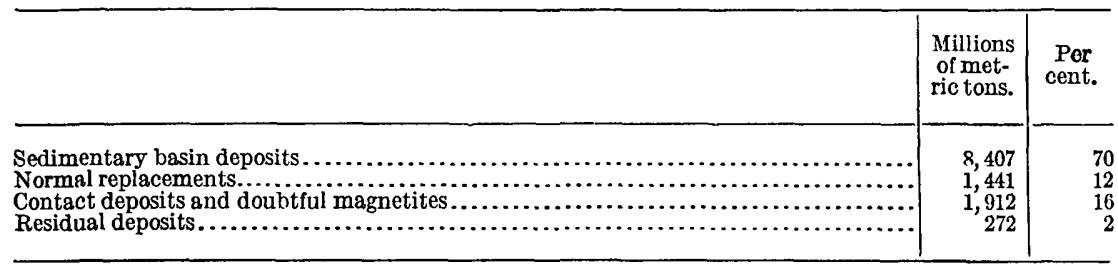

By using the classification already outlined and giving total iron content in "known," "probable," and "possible" ore, as shown by a detailed study of the reports on the deposits, the author obtained, independently, figures that are very close to those given by Eckel. They are shown in figure 3 , which indicates also the distribution of the sedimentary ores in geologic time.

Europe contains only small deposits of pre-Cambrian sedimentary ores like those of the Lake Superior region and Minas Geraes. Krivoi Rog, in southern Russia, is the only definitely sedimentary deposit which is believed to be pre-Cambrian. Some of the concentrating

6 Eckel, E. C., Iron ores, p. 41, McGraw-Hill Book Co., 1914. 
magnetite ores of Scandinavia may belong to the same class, but the evidence as to their origin is not complete.

Later sediments cover so large a part of Europe that the expo-

A.

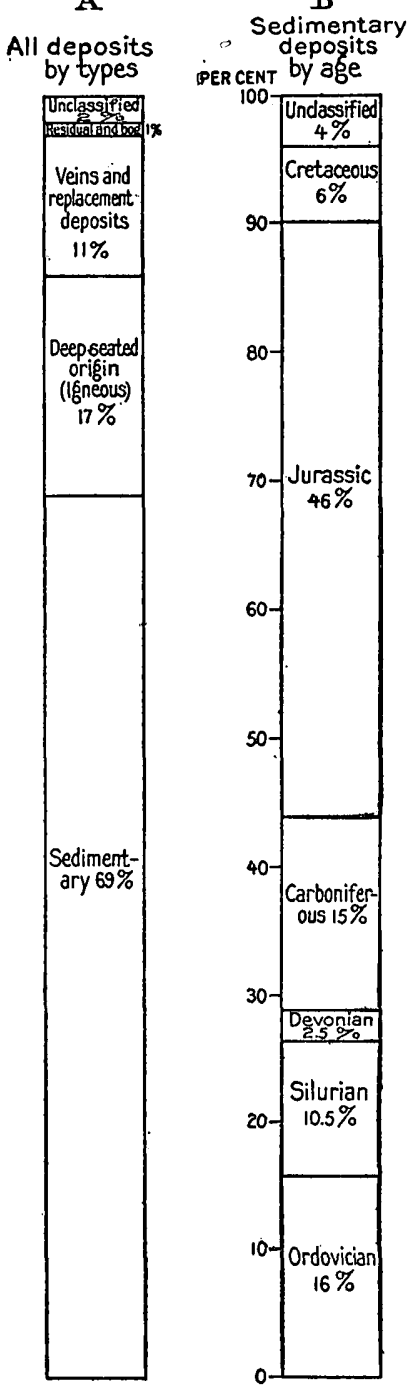

FIGURE 3.-Diagrams showing proportions of Europe's estimated iron reserves contained in ore deposits of different types (A) and different geologic ages (B). sures of Ordovician rocks there are very small. The only valuable sedimentary ores of that horizon are found in the folded rocks of the Armorican Peninsula, in Normandy.

Silurian oolitic ores are found in Brittany-Anjou, in the Thuringian Forest, and in central Bohemia, and there are other Silurian sedimentary ores in Spain in the ranges west of the Ebro. The famous Clinton ores o fthe eastern United States of America are of this age.

Devonian rocks are also of slight extent in Europe, and the sedimentary ores of that age are widely scattered in small bodies. The largest bodies are those of the Lahn-Dill syncline, the KellerwaldSauerland region, and the Harz Mountains, in Germany; of the Liége-Namur district, in Belgium; and of the March Valley, in Moravia. The ores of Belgium and Moravia are no doubt bedded ores, but the genesis of the Devonian ores in Germany is uncertain.

Carboniferous sedimentary ores are mined only in Great Britain, but those in the Campine coal field of Belgium may have a possible future.

To the Jurassic belong 46 per cent of the sedimentary ores in Europe, which are almost entirely oolitic ores. Oolitic Jurassic ores are found in the Lorraine Basin, in Haute-Marne, and in the Jurassic remnants of northwestern Germany. Sedimentary brown ores occur in the Jurassic of Poland. Oolitic silicate ores are found in the Jurassic at Chamoson and in the Erzegg-Planplatten district of Switzerland. Carbonate ores that are in part oolitic are found in the Jurassic series in England from Cleveland to Gloucester. 
According to De Lapparent ${ }^{7}$ early and middle Jurassic time, during which these ores were formed, was a period of gradual marine transgression under uniform rather high temperature in eastern Europe. The sediments deposited during the earliest part of the Jurassic were apparently sandy and included much coarse material and were therefore not very favorable to the deposition of iron ore. During the later part of early Jurassic and during middle Jurassic time the land areas were being eroded more slowly and the littoral deposits were rich in iron precipitates. Late Jurassic time was a period in which calcareous sediments were laid down, and in which large iron deposits were not formed, though some of the English ironstones belong in the lower horizon of the upper Jurassic.

- Cretaceous sedimentary ores do not form a very large part of the sedimentary ores of Europe. They are found in the Salzgitter-Iselde field of Germany and in the district west of the Rhine. Cretaceous ores are found also in Wilts and Kent, England.

The only important ores of recognized sedimentary type later than Cretaceous are the Pliocene ores of Kerch, on the Crimean Peninsula.

Next to the sedimentary ores in value are those of deep-seated origin. The ores of the Scandinavian massif and the big magnetite masses of Gora Blagodat and Magnitnaia, in the Ural Mountains, comprise the larger part of the European reserves of this type. Smaller deposits of magnetite in the Ural Mountain region and in the mountains between Bohemia and Germany make up the remainder. The amount of undesirable titaniferous ores in Europe is small compared with the deposits of titaniferous magnetites in the Adirondacks and in the Bushreld complex in South Africa. Deposits at Taberg in Sweden, at Val d'Aosta in Italy, on the Lofoter Islands, and in the Ural Mountain region are their only representatives.

Vein and replacement deposits are scattered through Europe and occur in rocks of all ages. All the deposits in Spain except those in the ranges west of the Ebro, all those in the Pyrenees, the deposits of Siegerland and Spessart in Germany, of Styria and Carinthia in Austria, all those in central Russia, and many of those in the Ural Mountain region, and in Cumberland and Lancaster in England belong to this class. These deposits supply a large part of the lowphosphorus ore mined in Europe-the type of ore required for making Bessemer steel.

Residual and bog ores are also widely distributed, but the only large deposits of these types are the chromiferous ores of Greece.

An unclassified group contains the pyritic ores from which the "purple ore" is derived, minor deposits that have been grouped together, and deposits on whose genesis evidence is lacking or too conflicting for decision.

7 Lapparent, A. de, Traité de géologie, 4th ed., vol. 2, pp. 1045-1056, Paris, 1900. 


\section{PRODUCTION AND CONSUMPTION.}

The production and the consumption of iron ore in Europe in 1913 are summarized in the following table and in figures 4 and 5 , which are based on official statistics of production, export, and import. Consumption represents production plus imports minus exportsthat is, ore available for consumption. The figures showing consumption are not so accurate as those showing production, for no account is taken of changes in stocks.

Iron ore produced and consumed in Europe in 1919.

\begin{tabular}{|c|c|c|c|c|c|}
\hline \multirow[b]{2}{*}{ Country or district. } & \multicolumn{3}{|c|}{ Production. } & \multicolumn{2}{|c|}{ Consumption. } \\
\hline & Quantity (m & etric tons). & $\begin{array}{c}\text { Per } \\
\text { cent of } \\
\text { total. }\end{array}$ & $\begin{array}{c}\text { Quantity } \\
\text { (metric tons). }\end{array}$ & $\begin{array}{l}\text { Per } \\
\text { cent of } \\
\text { total. }\end{array}$ \\
\hline $\begin{array}{l}\text { Austria-Hungary: } \\
\text { Austria........... } \\
\text { Hungary } . . . . . . . \\
\text { Bosnia.......... }\end{array}$ & $\begin{array}{r}3,039,324 \\
2,059,076 \\
220,131\end{array}$ & & & & \\
\hline 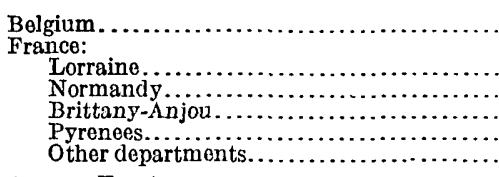 & $\begin{array}{r}19,978,937 \\
812,984 \\
269,703 \\
393,844 \\
462,402\end{array}$ & $\begin{array}{r}5,318,531 \\
1.49,450\end{array}$ & $\begin{array}{r}4.9 \\
.1\end{array}$ & $\begin{array}{l}6,155,000 \\
7,100,000\end{array}$ & $\begin{array}{l}5.6 \\
6.5\end{array}$ \\
\hline 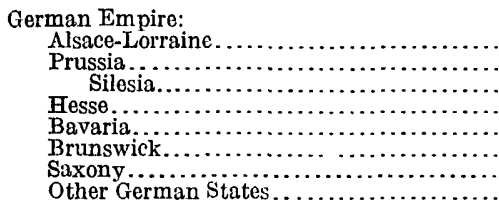 & $\begin{array}{c}21,136,265 \\
5,669,786 \\
{[165,545]} \\
887,486 \\
485,254 \\
256,879 \\
2,725 \\
169,508\end{array}$ & $21,917,870$ & 20.4 & $13,000,000$ & 11.9 \\
\hline 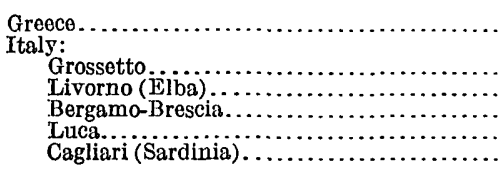 & $\begin{array}{r}27,698 \\
548,672 \\
11,762 \\
3,302 \\
11,682\end{array}$ & $\begin{array}{l}607,903 \\
309,956\end{array}$ & $\begin{array}{r}26.5 \\
.3\end{array}$ & $37,995,000$ & 34.8 \\
\hline 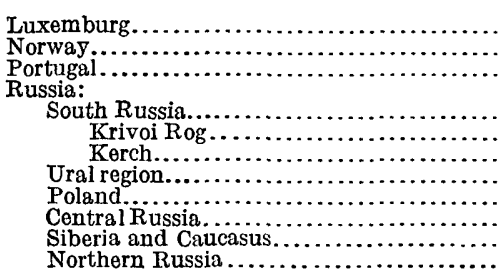 & $\begin{array}{r}6,880,931 \\
{[6,347,600]} \\
{[479,500]} \\
l, 800,206 \\
311,228 \\
526,548 \\
3,604 \\
3,292\end{array}$ & $\begin{array}{r}603,116 \\
7,333,372 \\
544,443 \\
49,162\end{array}$ & $\begin{array}{l}.55 \\
6.8 \\
.5 \\
.05\end{array}$ & $\begin{array}{r}601,000 \\
9,005,000\end{array}$ & $\begin{array}{l}.6 \\
8.3\end{array}$ \\
\hline 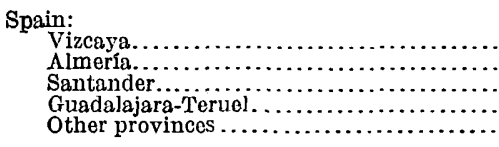 & $\begin{array}{r}3,864,593 \\
1,350,247 \\
1,278,087 \\
940,835 \\
2,427,906\end{array}$ & $9,52.5,809$ & 8.8 & $9,100,000$ & 8.4 \\
\hline 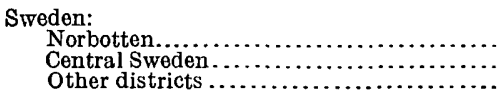 & $\begin{array}{r}4,913,603 \\
2,428,659 \\
133,309\end{array}$ & $9,861,668$ & 9.1 & 954,000 & .9 \\
\hline 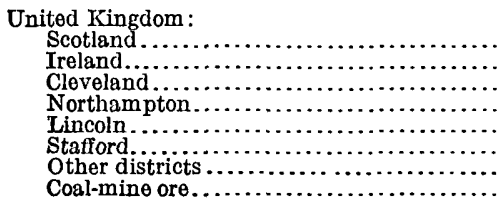 & $\begin{array}{r}601,055 \\
60,977 \\
6,136,595 \\
2,963,521 \\
2,683,117 \\
904,976 \\
2,904,842 \\
{[1,286,739]} \\
\end{array}$ & $7,475,571$ & 7.0 & $1,120,000$ & 22.0 \\
\hline & & $107,950,703$ & 100.0 & $109,030,000$ & 100.0 \\
\hline
\end{tabular}


Production

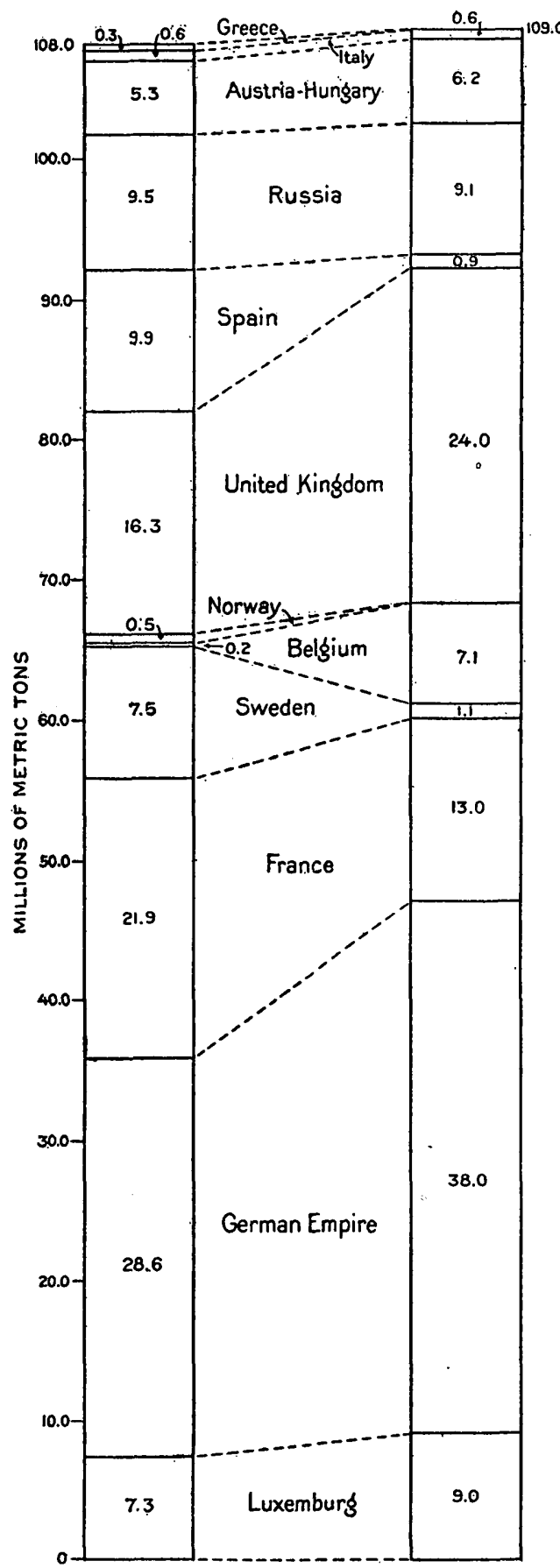

FTGURE 4.-Chart showing amounts of iron ore produced and consumed in Europe as a whole and in the several European countries in 1913.
The excess of $1,000,000$ tons of ore available for consumption over the quantity of ore produced represents the imports from countries outside of Europe, including a part of the $1,350,000$ tons produced in Algeria.

Figure 4 shows that Europe is practically selfsupporting so far as its ironore industry is concerned. Italy, Austria, Hungary, and Russia are nearly self-supporting. Spain as exporter and the United Kingdom as consumer form a group, and France, Germany, Luxemburg, and Belgium consumed the excess of Scandinavian as well as their domestic production.

Figure 5 shows the position of the individual countries in 1913 as producers or consumers. Norway, Sweden, and France had large oversupplies to export. Belgium, the United Kingdom, and the German Customs Union (Germany and Luxemburg) were forced to import a large part of the ore they used.

Figure 6, which is based on statistics for 1913, shows the changes in producing capacity brought about by the war. The striking feature shown is the reduction of the output of Germany from 26.5 
per cent to only 7.5 per cent of the output of Europe. The diagram also indicates the splitting up of Austria-Hungary and of Russia.

The iron industry in Europe labors under several disadvantages as compared with the industry in the United States. Perhaps the greatest of these disadvantages is the low output of iron per man employed in mining ore. The following table gives some figures for comparison:

Iron in ore mined per man per year.
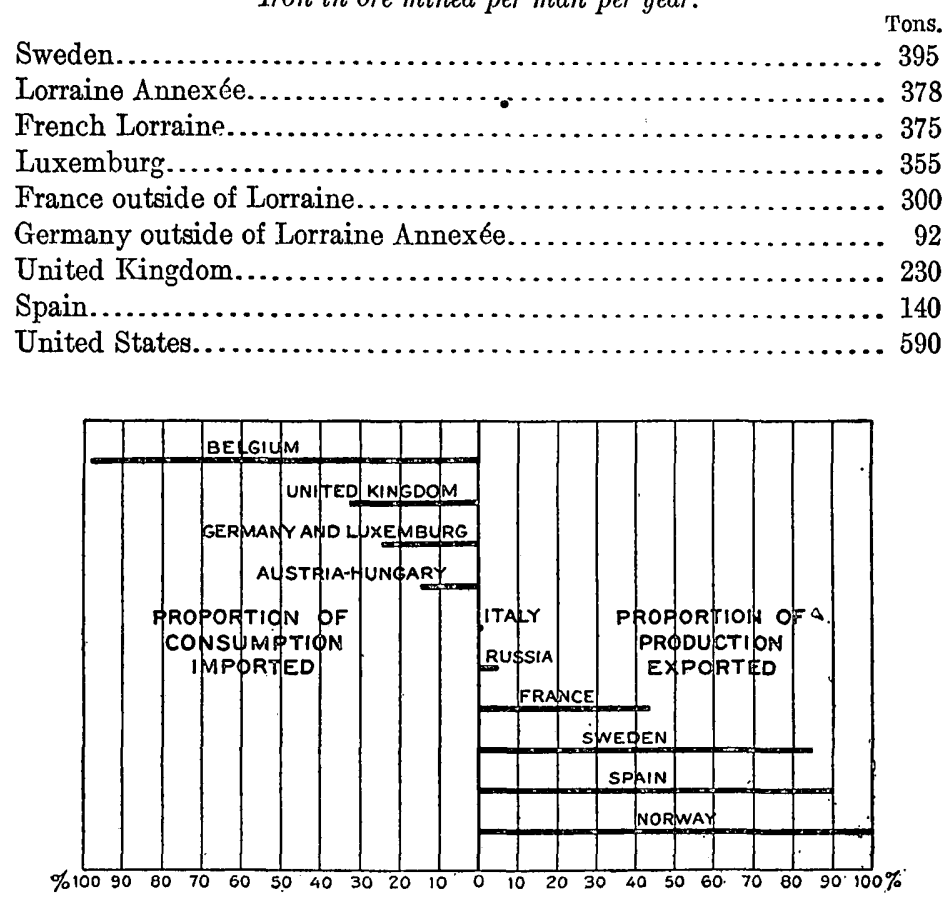

FraURE 5.-Chart showing proportion of total iron ore consumed supplied by net imports of proportion of total iron ore produced going to net exports in 1913 for several countries in Europe.

The figures representing the annual output per man in the other important branch of the iron industry, coal mining, show a similar difference between the product of labor in Europe and in the United States.

A further disadvantage in Europe appears to be the comparatively low blast-furnace output. In the United States the tendency to develop or improve the unit and to decrease the number of units employed has resulted in an annual output of 120,000 tons per blast furnace. In Europe, where the tendency is to keep old equipment in service as long as possible without improvement, the annual output per furnace is much less. In Germany it is 55,500 tons and in England it is 28,000 tons.

If greater output per unit is a measure of efficiency Europe falls far below the United States in the three elements of output in the 
iron industry-iron in ore mined per man, coal mined per man, and

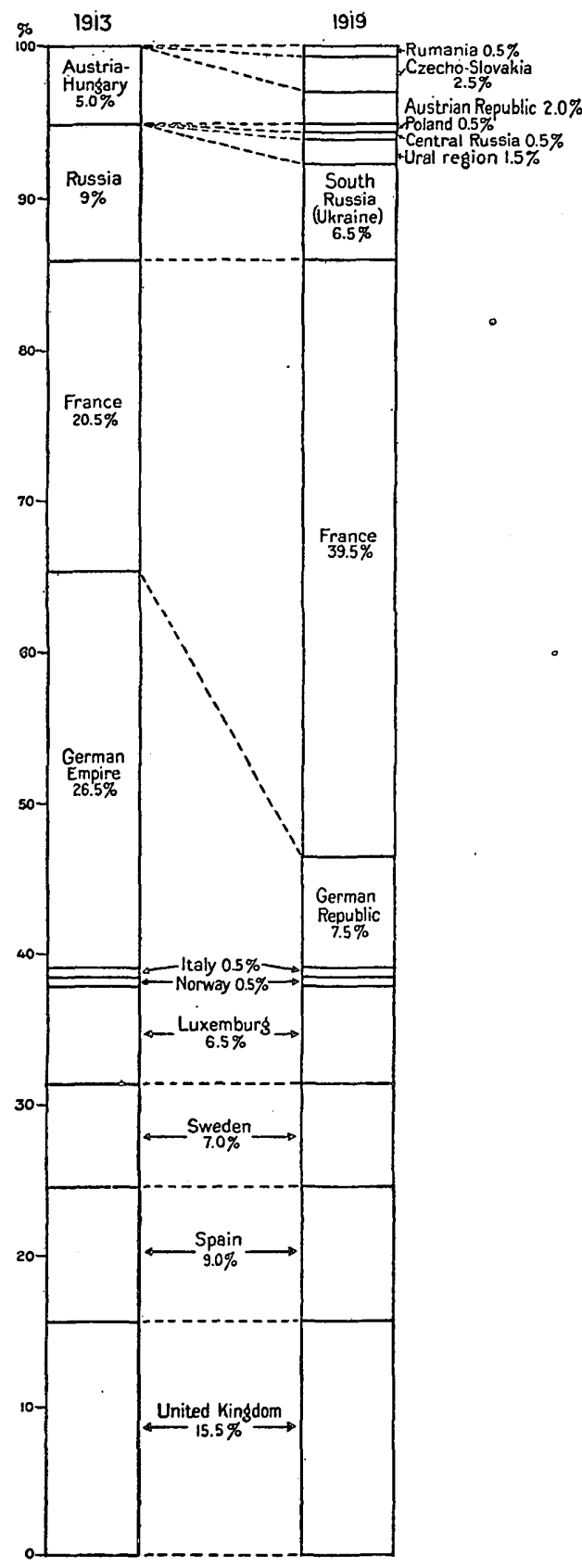

FIgURE 6.-Chart showing proportional contributions of the several countries to the total quantity of iron ore produced in Furope in 1913 and proportions of potential output under the political subdivisions of 1919 . pig iron produced per furnace; but as Europe has heretofore been able to compete with the United States in cost of product she must have had some counterbalancing means of economy in production. One of these may have been cheaper transportation. In the United States the great ore-producing center is the Lake Superior district, and the great coal-producing center of the Appalachians is on an average 725 miles away from the iron and is 125 miles from tidewater. In England coal and iron are close together and are so near tidewater that they can be cheaply shipped for export. On the Continent the Lorraine Basin is separated from the Westphalian coal field by only 200 miles, and the coal field is connected with tidewater by an excellent canal and river system.

Another means of economy in production in Europe has been an abundant supply of cheap labor, which has enabled the European producers to turn out cheap products from comparatively poor natural material without employing labor-saving devices to the extent that they have been employed in the United States. This advantage, however, has had the evil effect of producing a

surplus of finished products for the domestic market. Cheap labor, 
more or less discontented, can not supply the ultimate market supplied by high-priced labor, with its higher standard of "necessities." The fact that the domestic markets in Europe could not take their proper share of the finished products no doubt added to the need for foreign markets, and that need had its due share in precipitating the World War.

Europe's supply of labor is bound to be great, but it does not now seem to be willing to continue cheap. It is difficult to forecast the future of Europe's iron industry, but a rather chaotic period of reconstruction seems inevitable. Better-paid labor will enforce more efficient mining and smelting, greater mass production, and the further use of labor-saving devices; and deposits that are not well adapted to the altered conditions will be abandoned and foreign deposits that can supply cheaper raw materials will be drawn upon. Among such foreign deposits would be those of Cuba and Brazil.

In countries where nearly all the ore mined is exported, such as Sweden; Norway, and Spain, the future will probably bring only slight changes. The United Kingdom, with her large mining and smelting industry, will feel the new conditions keenly; indeed, her industrial future will doubtless depend on the speed with which she adapts herself to those conditions. The future of the iron industry of France and Germany will depend on their cooperation. The extent to which Westphalian coal and Lorraine iron ore are utilized together will measure the extent of their success or failure. Luxemburg also is dependent on Westphalian coal but has not sufficient iron ore to export it to Germany in exchange for coal. Belgium is almost entirely dependent on foreign deposits for the iron ore to supply her blast furnaces, and she has in the past drawn on Westphalia for coal to augment her own supplies. Czecho-Slovakia and Russia are almost entirely independent as to raw materials. Italy lacks coal and does not make much pig iron, but she has developed a very good steel industry from imported material. Austria is dependent on foreign sources for coal. If she is to use English coal, as she has in the past, she must import it through territory that has been hostile to her. Poland has not the resources to develop more than a small iron industry. Switzerland, Holland, Denmark, and the new Baltic States have no resources of their own on which to base any extensive iron industry.

\section{COMPARISON OF CONTINENTS.}

The world's iron-ore resources are not sufficiently explored to permit an exact comparison of the resources of the several continents, but an approximate comparison may be allowable.

The reserves of North America are well known but have never been calculated to the same exactness nor to the same lower limit 
of grade as those of Europe. If so estimated they could probably be counted on for three times as much iron as those of Europe.

The resources of South America are not so well known. Extensive deposits of deep-seated origin lie along the western slopes of the Andes, and immense pre-Cambrian reserves are found in Minas Geraes and Urucu in Brazil. The ore in the Minas Geraes district that contains over 45 per cent of iron, according to an estimate made by the author from information supplied by E. C. Harder and B. L. Miller, carries more iron than that in all Europe, and the inclusion of ores of lower grade would greatly increase the estimate. If its reserves are estimated as closely as those of Europe have been South America would undoubtedly prove to have at least twice as much iron as Europe.

The information concerning Africa is very indefinite. Except the writers of some French and German reports on the iron-ore deposits of northern Africa, the men reporting on the deposits of that continent have regarded them as abstract geologic phenomena, whose economic value was of no interest. It is this lack of records of practical value that has compelled the writer to estimate the iron ores of Africa at about one-sixth of those of Europe.

The iron-ore reserves of Asia are not well known. Mines are working in China and Chosen, India has considerable reserves and a small industry, and Siberia has extensive reserves. Large deposits of laterites are found in the Philippines. Probably Asia can be counted on for at least three-fourths as much iron as Europe.

Oceania has enough iron ore to support a local industry, but her reserves do not amount to an appreciable part of the world's total.

A summary of the iron-ore reserves of the world, in which those of Europe are reckoned as unity, shows the following comparative figures, which, however, because of a lack of complete knowledge, are admittedly not precise:

Iron-ore resources of the world.

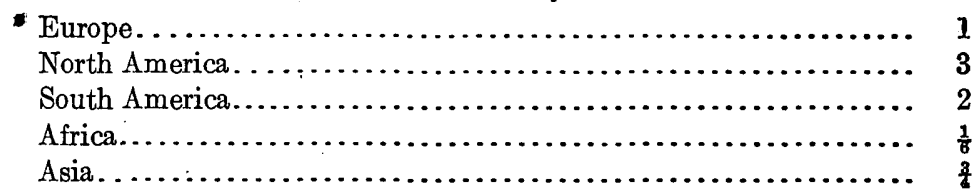

These figures indicate that the world's available supply of iron would last more than 1,000 years at the rate of production of 1913 . On the other hand, if production continues to increase at the pre-war rate, which was 25 per cent in every five years, the supply would be exhausted in about 130 years. Use at this rate would involve the consumption of $6,000,000,000$ tons of pig iron in the year 2043, as compared with about $80,000,000$ in 1913. A growth of industry so great as this output would imply does not seem to be probable. A 
considerable reduction in the rate of increase in production and a correspondingly longer life of the world's iron-ore reserves seem far more likely.

SPAIN.8

DISTRIBUTION, CHARACTER, AND EXTENT OF THE DEPOSITS.

Deposits of iron ore are scattered all through Spain. (See Pl. II, in pocket.) Fortunately the larger deposits are not far from tidewater. Some of these deposits have been for many years the sources of considerable iron ore and they have therefore been carefully studied, so that the information about them is unusually complete. The deposits are here grouped geographically according to the mountain ranges in which they are found and by provinces. The greater part of the data on the available reserres is taken from a report made by Vidal.

\section{- CANTABRIAN CORDILLERA.}

The mountain range along the northern coast of the Iberian Peninsula furnishes more than half the iron ore produced in Spain. The deposits are found in the Provinces of Lugo, León, Oviedo, Santander, Vizcaya, and Álava.

Lugo Province. ${ }^{9}$-The ore bodies in the Province of Lugo are brown ore and spathic ore, which occur in crystalline Paleozoic schists. The greater part of the ore in Lugo contains a medium amount of phosphorus. The ores of Incio and Brollon are of Bessemer grade. Ore is found also at Vivero, Villamea, Muras, Villaodrid, and Basmonde. Except the ore at Villamea, which contains an average of 35 per cent of iron, these ores contain more than 48 per cent of iron. According to Vidal ${ }^{10}$ there are $122,000,000$ metric tons of ore in the province. In the estimate below a little has been added in the "possible" class to this total.

Iron resources of the Province of Lugo, Spain.

[Millions of metric tons.]

\begin{tabular}{|c|c|c|}
\hline & Ore. & Iron. \\
\hline 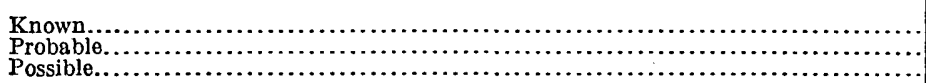 & $\begin{array}{l}70 \\
30 \\
40\end{array}$ & $\begin{array}{l}35.0 \\
13.5 \\
16.0\end{array}$ \\
\hline
\end{tabular}

8 Vidal, L. M., Résumé des gisements de fer de l'Espagne: The iron-ore resources of the world; an inquiry made upon the initiative of the Executive Committee of the 11th International Geological Congress, vol. 1, pp. 47-85, Stockholm, 1910. Ahlburg, J., Die nutzbaren Mineralien Spaniens und Portugals: Zeitschr. prakt. Geologie, vol. 15, pp. 183-210, 1907. McBride, H. A., Production of iron ore in Spain: Mines and Minerals, vol. 31, pp. 577-580, 1911.

${ }^{9}$ Teichgräber, -, Eisenerzvorkommen in Galicien, Spanien: Stahl und Eisen, vol. 24, pp. 332-334, 1904. 10 Op. cit., pp. 54-57. 
León Province. ${ }^{11}$-The deposits in the Province of León are of two very different types and value. At the Wagner group of mines, between Ponferrada and Astorga, the ore occurs as bedded lodes of siderite superficially altered to brown ore. The ore contains from 49 to 52 per cent of iron and 1.6 per cent of phosphorus. The deposit is estimated to contain 25,000,000 tons. Besides this there is in the province $100,000,000$ tons of low-grade ore containing 32 to 44 per cent of iron, 0.13 to 0.5 per cent of phosphorus, and high silica, deposited in ferruginous sandstone. In estimating the reserve in this province the deposit at the Wagner mines has been considered "known," for the only factor militating against its exploitation is the difficulty of transportation. The deposits in sandstone have been classed as a "possible" reserve.

Iron resources of the Province of Lebn, Spain.

[Millions of metric tons.]

\begin{tabular}{|c|c|c|}
\hline & Ore. & Iron? \\
\hline $\begin{array}{l}\text { Known } \\
\text { Possible, }\end{array}$ & $\begin{array}{r}25 \\
100\end{array}$ & $\begin{array}{l}12.5 \\
35.0\end{array}$ \\
\hline
\end{tabular}

Oviedo Province. ${ }^{12}$-In Oviedo, as in León, there are two kinds of deposits. Near the Picos d'Europa there are beds of brown ore and hematite in Carboniferous limestone. They contain 57 to 64 per cent of iron, 0.005 to 0.15 per cent of sulphur, and 0.011 to 0.123 per cent of phosphorus. Of ore of this class it is estimated that there is 62,000,000 tons. In central Oviedo, at Proaza, Teverga, Careno, and other places, there are deposits of ferruginous sandstone which has been mined for use as flux in the smelters at Bilbao.

Iron resources of the Province of Oviedo, Spain.

[Millions of metric tons.]

\begin{tabular}{|c|c|c|}
\hline . & Orę. & Iron. \\
\hline 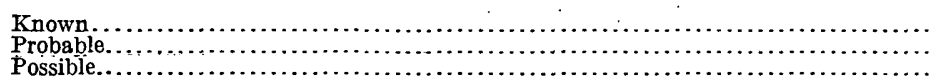 & $\begin{array}{l}60 \\
50 \\
50\end{array}$ & $\begin{array}{l}36.0 \\
20.0 \\
17.5\end{array}$ \\
\hline
\end{tabular}

Santander Province.-About 12 per cent of the iron ore produced in Spain comes from the Province of Santander. It is Bessemer ore of good grade, of the sort that has given high repute to Spanish ore.

11 Jones, J. A., Development and working of minerals in the Province of Le6n, Spain: Inst. Min. Eng. Trans., vol. 20, p. 420, 1901.

12 Grosch, P., Roteisensteinlager in Asturien: Zeitschr. prakt. Geologie, vol. 20, pp. 201-205, 1912. Jones, J. A., The Devonian iron ores of Asturias: Inst. Min. Eng. (London) Trans., vol. 18, pp. 279-292, 18991900. Adaro, L. de, and Junquera, G., Criaderos de hierro de Asturias: Inst. geol. España Mem., vol. 2, 1916. Nicou, P., and Schlumberger, C., L'industrie minière et métallurgique dans les Asturies: Annales des mines, 10th ser., vol. 7, pp. 203-260, 1905. 
The deposits are brown ores in clay, which occur on a footwall of Cretaceous limestone and are said to be the result of the "decalcification" of the limestone. The deposits range in thickness from 10 centimeters to 70 meters and are not covered. The larger deposits are at Cabarga and Camargo and are mined by open cut. A bout $5,000,000$ tons has been mined since an estimate of $22,950,000$ tons was made by Vidal. ${ }^{13}$ Allowing for developments and mining, it is estimated that the known ore in the province amounts to $20,000,000$ metric tons, containing 9,000,000 metric tons of iron.

Vizcaya Province. ${ }^{14}$-The location of the deposits in the vicinity of Bilbao is shown in Plate III. These deposits have been the mainstay of iron-ore production in Spain, but they have probably passed their period of maximum productivity, though there remains a very considerable reserve.

According to De Launay ${ }^{15}$ the deposits were formed by the replacement of limestone by ores derived from ascending solutions. Where the solutions passed through sandstone or shale, formations which are less easily attacked, they formed veins. The bodies have undergone metamorphism since their deposition. The ore minerals are siderite, hematite, and brown ore. Commercially four types of ore are recognized:

Vena: Very pure earthy hematite.

Campanil: Crystalline hematite with large crystals of calcite. ("Campanil" means bell metal, a name suggested by the resonance of the ore when struck with a hammer.)

Rubio: Red concretionary hematite.

Siderite: Found at depths.

Analyses of iron ore from the Province of Vizcaya, Spain.a

\begin{tabular}{|c|c|c|c|c|c|}
\hline Type of ore. & $\mathrm{Fe}$. & Mn. & $\mathrm{CaO}$. & $\mathrm{SiO}_{2}$ & P. \\
\hline 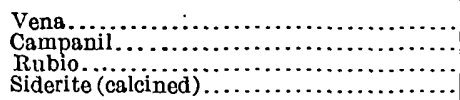 & $\begin{array}{l}49 \text { to } 60 \\
48 \text { to } 58 \\
48 \text { to } 58 \\
54 \text { to } 62\end{array}$ & $\begin{array}{l}0.5 \text { to } 1.5 \\
1 \text { to } 4 \\
.5 \text { to } 2 \\
\cdots\end{array}$ & $\begin{array}{r}0.1 \text { to } 9 \\
.5 \text { to } 5 \\
.5 \text { to } 2 \\
. .\end{array}$ & $\begin{array}{l}1 \text { to } 7 \\
3 \text { to } 6 \\
2.5 \text { to } 14 \\
\ldots \ldots \ldots \ldots\end{array}$ & $\begin{array}{l}\text { Trace. } \\
\text { Trace to } 0.2 \\
\text { Trace to } 0.9 \\
\end{array}$ \\
\hline
\end{tabular}

a Vidal, L. M., Résumé des gisements de fer de l'Espagne: The iron-ore resources of the world (11th Internat. Geol. Cong.), vol. 1, p. 51, 1910.

The main masses of ore are found southwest of Bilbao along the flanks of an anticline striking northwestward for 30 kilometers and are 2 to 8 kilometers wide.

13 Vidal, L. M., op. cit., p. 61.

14 Brough, B. H., The iron-ore mines of Biscay: Cassier's Mag., vol. 23, pp. 697-709, 1903. Dann, E., Die Eisenerzlager und die Eisenindustrie von Bilbao: Stahl und Eisen, vol .33, pp. 1181-1185, 1232-1236, 1913. John, - Die Eisenerzlagerstätten von Bilbao und ihre Bedeutung für die zukünftige Eisenerzversorgung Grossbritanniens und Deutschlands: Glückauf, vol. 46, pp. 2002-2013, 2045-2052, 1910. Adams, F. D., Notes on the iron-ore deposits of Bilbao: Canadian Min. Inst. Jour., vol. 4, pp. 196-204, 1901.

1s Launay, L. de, Traité de métallogénie: Gites minéraux et metallifères, vol. 2, pp. 380-381, Paris et Liége, 1913.

$$
15945^{\circ}-21-\text { Bull. } 706-3
$$


At the time the estimates given by Vidal were made the value of the siderite was not well recognized, and the extension of work to greater depths than those then figured now seems probable. Vidal's estimate of the ore near Bilbao ${ }^{16}$ minus the ore mined since is accepted, and a considerable addition is made for "possible" ore from greater depth and further development.

Iron resources of the Province of Vizcaya, Spain.

[Millions of metric tons.]

\begin{tabular}{|c|c|c|}
\hline & Ore. & Iron. \\
\hline 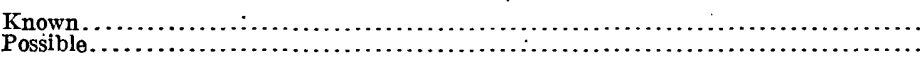 & $\begin{array}{l}35 \\
30\end{array}$ & $\begin{array}{r}17.5 \\
13.5\end{array}$ \\
\hline
\end{tabular}

Álava Province.-Near Villambrosa, in the Province of Álava, there is a vein of hematite ore, which, however, is of no economic value.

Summary for the Cantabrian Corditlera.-The table below summarizes the quantities of metallic iron in deposits in the Cantabrian Cordillera.

Iron in ores in the Cantabrian Cordillera, Spain.

[Millions of metric tons.]

\begin{tabular}{|c|c|c|c|}
\hline Province. & Known. & Probable. & Possible. \\
\hline \multirow[t]{2}{*}{ 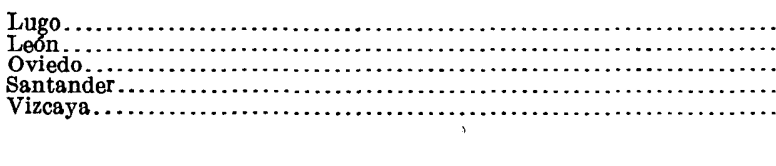 } & $\begin{array}{r}35.0 \\
12.5 \\
36.0 \\
9.0 \\
17.5\end{array}$ & $\begin{array}{r}13.5 \\
\cdots \ldots .0 \\
20.0 \\
\cdots \ldots \\
\cdots \cdots\end{array}$ & $\begin{array}{l}16.0 \\
35.0 \\
17.5 \\
\dddot{13.5}\end{array}$ \\
\hline & 110.0 & 33.5 & 82.0 \\
\hline
\end{tabular}

THE PYRENEES.

The deposits along the southern flanks of the Pyrenees are of far less extent than those of the range along the north coast. They occur in the Provinces of Guipuzcoa, Navarra, Huesca, Lerida, and Gerona.

Guipuzcoa and Navarra provinces. ${ }^{17}$-In the eastern part of Guipuzcoa, at Ardituri and Berastegui, and in Navarra, at Irun and Lesaca, there are bedded lodes of hematite and siderite. They appear to be of the same type as the ores of the eastern Pyrenees, in France. The hematite contains 40 per cent of iron; the calcined siderite 55 to 58 per cent of iron and low phosphorus.

At Cerain and Multiloa, in Guipuzcoa, there are brown ores that fill cavities in Cretaceous limestone.

16 Vidal, L. M., op. cit., p. 53.

17 Mallada, L., Datos geologico-mineros de varios criaderos de hierro de España: Com. mapa geol. Bol., vol. 26, pp. 152-203, 1899. 


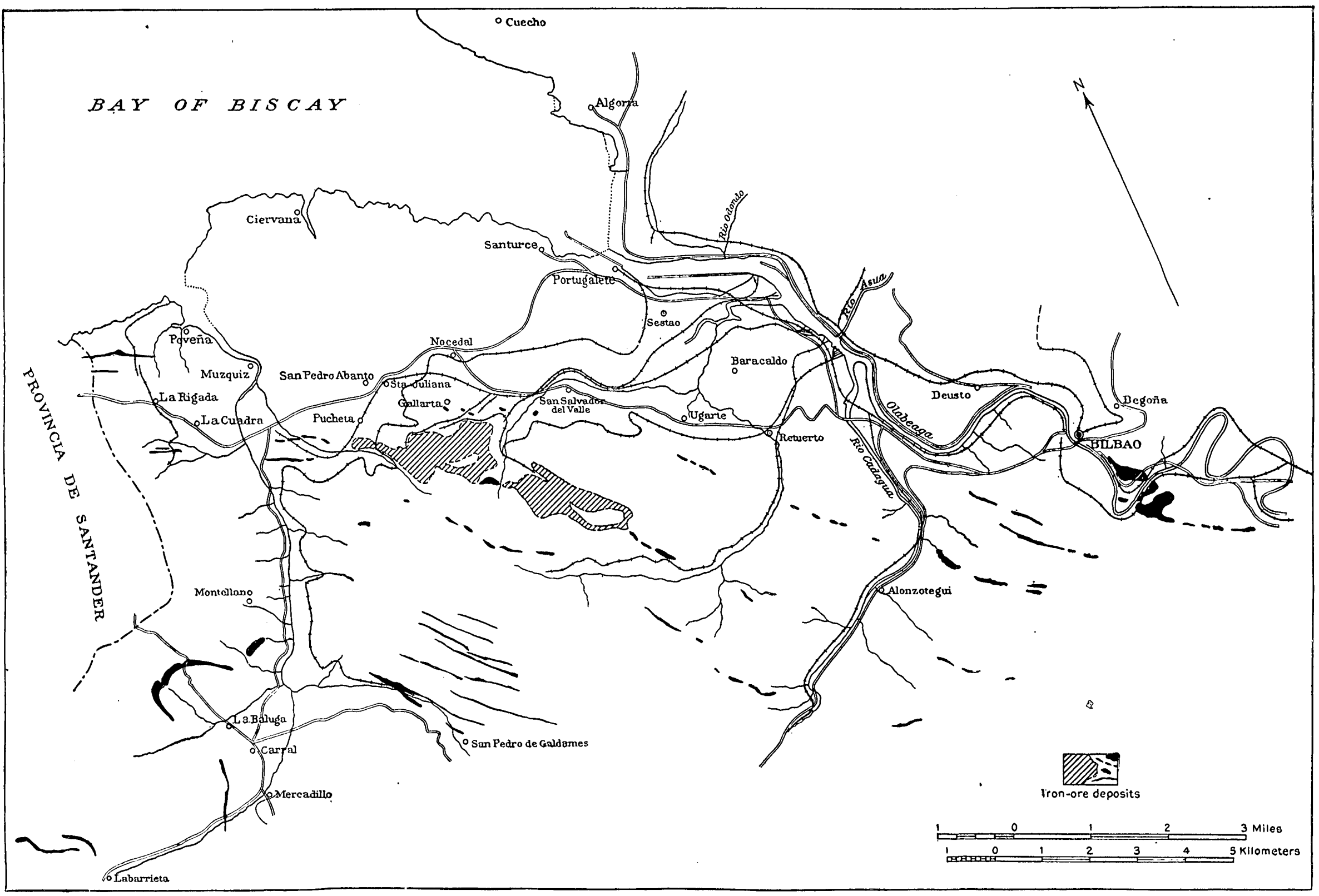

MAP SHOWING THE DISTRIBUTION OF IRON-ORE DEPOSITS IN VIZCAYA PROVINCE. SPAIN. 
Iron resources of the Provinces of Guipuzcoa and Navarra, Spain.

[Millions of metric tons.]

\begin{tabular}{|c|c|c|}
\hline & Ore. & Iron. \\
\hline 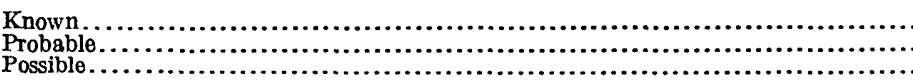 & $\begin{array}{l}8 \\
4 \\
4\end{array}$ & $\begin{array}{l}3.6 \\
1.8 \\
1.6\end{array}$ \\
\hline
\end{tabular}

Huesca Province.-From Huesca are reported deposits of magnetite at Queto, a vein of siderite near Bielsa, and brown ores in Triassic limestone at Calasanz. Nothing is recorded as to their extent or character.

Lerida Province.-In Lerida there is a vein of brown ore at Aynet de Besan, siliceous brown ore at Arseguel, very pure hematite in limestone at Ager, and brown ores that are said to be valuable at Bausen.

Gerona Province.-Near Celra, in the range between Celra and Gerona, there are some beds of brown ore interstratified with Silurian schists. They were formerly exploited for the furnaces at Le Creuzot. They appear to be extensive, but no data are given as to the extent to which they have been exhausted.

Summary for the Pyrenees. -The only ores in the Pyrenees on which quantities can be calculated are those of Guipuzcoa-Navarra, which, estimated in metric tons of iron, may be reckoned asknown, 3,600,000; probable, 1,800,000; possible, 1,600,000.

\section{RANGES WEST OF EBRO RIVER.}

In the ranges west of the Ebro there are several deposits of bedded brown ores and some hematite, which are associated with sediments of Silurian age. They are found in the Provinces of Logroño, Soria, and Saragossa.

Logrono Province.-In the Province of Logroño iron ores are found near Ezcaray, in the Sierra de la Demanda. They are of low grade, containing only 32 per cent of iron, and can be considered only as a "possible" reserve, comprising 20,000,000 metric tons of ore containing 6,400,000 metric tons of iron.

Soria Province.-Near Olvega there are reported to be small deposits of ores of low grade.

Saragossa Province. - The ore found near Tierga, in the Sierra de la Virgen, is of better grade, as it is nearly all hematite containing over 60 per cent of iron and low phosphorus. The known reserve amounts to $34,000,000$ metric tons of ore containing $18,700,000$ metric tons of iron.

Summary for ranges west of Ebro River.-The deposits in the Province of Logroño contain 6,400,000 metric tons of "possible" iron; 
those in the Province of Saragossa contain 18,700,000 metric tons of "known" iron.

\section{SIERRA MENERA. ${ }^{18}$}

The iron ores of the Sierra Menera, a range that passes from the Province of Guadalajara into the Province of Teruel, lie near the boundary between these Provinces, as shown in figure 7. The deposits have been looked upon as a promising substitute for the declining deposits on the north coast. The detailed studies of thess

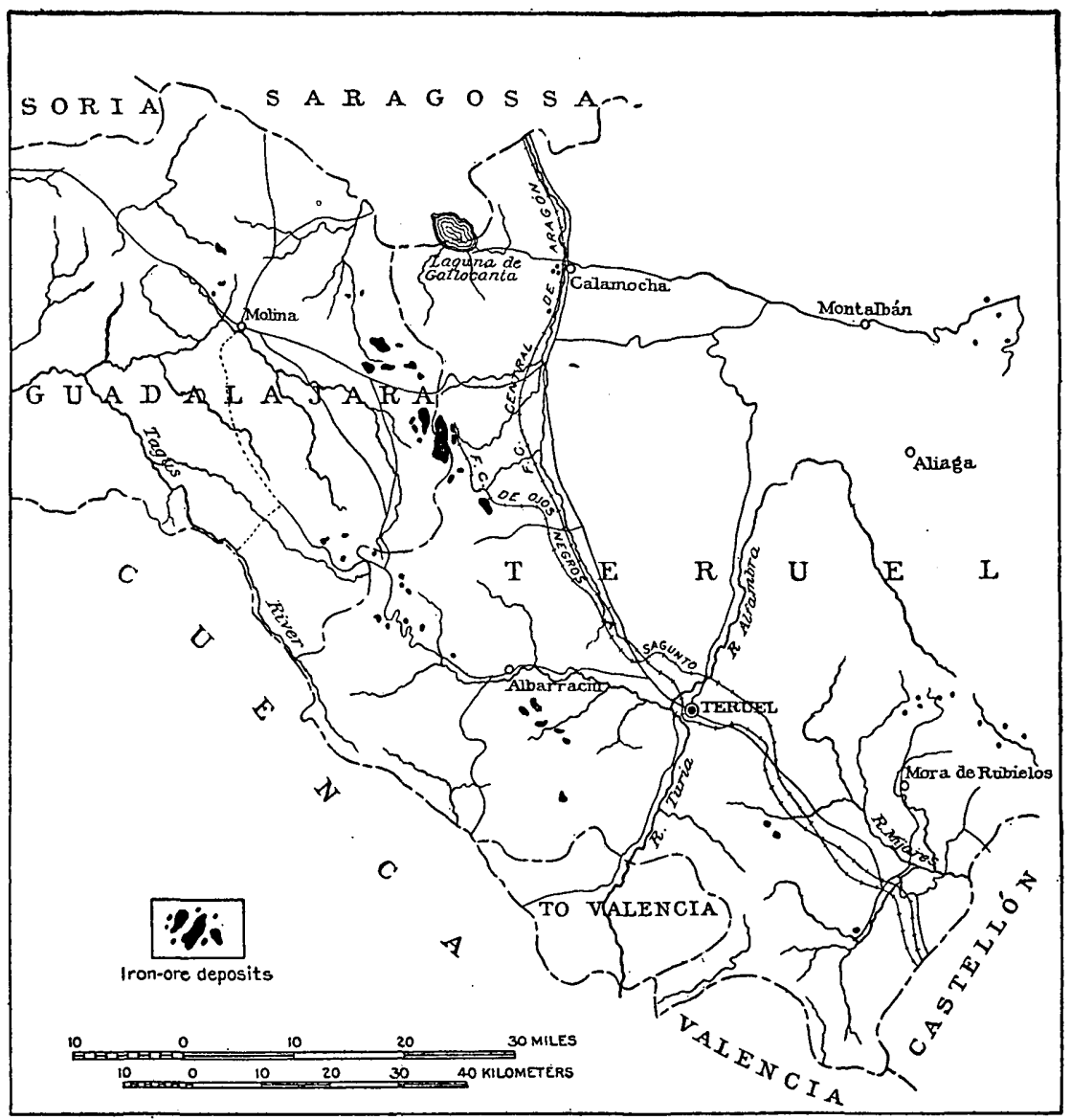

FIGURE 7.-Map showing deposits of iron ore in the Sierra Menera, Spain. (From Inst. geol. España Mem., 1918.)

deposits by Kindelan ${ }^{10}$ rank among the most careful and thorough yet made.

The deposits are brown ores, very light in weight, associated with metamorphosed Silurian sediments. They contain over 50 per cent

18 Kindelan, V., and Ranz, Manuel, Los criaderos de hierro de Guadalajara y Teruel: Inst. geol. Mem., vol. 3, 1918. Ysassi, V. de (edited by A. S. Callen), The iron mines of the Sierra Menera district of Spain: $\Lambda \mathrm{m}$. Inst. Min. Eng. Trans., vol. 53, pp. 84-89, 1915.

10 Kindelan, V., op. cit., pp. 1-121. 

Huelva Province.-At Cala there are veins of magnetite and brown ore in diabase. They contain 51 to 58 per cent of iron, 12 to 20 per cent of silica, and less than 0.02 per cent of phosphorus. Their content of sulphur becomes higher with increase of depth. They have been estimated to contain from $6,000,000$ tons (J. Crum) to $16,000,000$ tons (E. Klockmann).

At Tueler, near Cala, ore of the same type occurs in the same way, but it contains more phosphorus ( 0.05 per cent). The deposit is said to contain $15,000,000$ tons.

The pyritic deposits of Rio Tinto, which furnish iron ore as a byproduct after roasting, must be counted as a reserve, for the ore is shipped to the blast furnace. The deposits contain by estimate $150,000,000$ tons "known" and an equal quantity of "probable" ore.

Iron resources of the Province of Huelva, Spain.

[Millions of metric tons.]

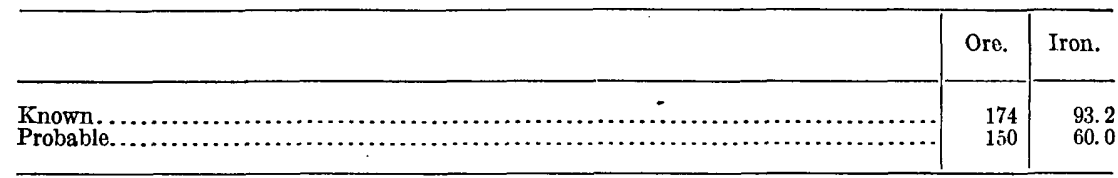

Seville Province. ${ }^{22}$-Bodies of magnetite and of brown ore are reported to occur in Cambrian schists at Almaden de la Plata and Pedrozo, veins of carbonate are reported to occur in Cambrian rocks in the Sierra de Jayona, and an extensive area of float ore is said to be found on the Cerro de Hierro. The ore bodies have been but slightly developed and the available estimates, which place the resources at 18 to 35 million metric tons of known ore, seem to be inadequate.

Iron resources of the Province of Seville, Spain.

[Millions of metric tons.]

\begin{tabular}{|c|c|c|}
\hline & Ore. & Iron. \\
\hline 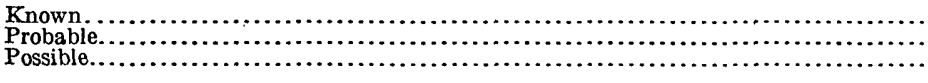 & $\begin{array}{l}18 \\
18 \\
18\end{array}$ & $\begin{array}{l}9 \\
9\end{array}$ \\
\hline
\end{tabular}

Jaén Province.-At the east end of the Sierra Morena, in the Province of Jaén, there are ferruginous sandstones, which are probably of no commercial value. South of the Guadalquivir there are lenses of hematite containing little silica and phosphorus, which are now being exploited. Their extent is not known.

Summary of Sierra Morena.-The resources of the Sierra Morena are tabulated on page 39.

${ }_{22}^{22}$ Yarza, De R., Additional data on iron-ore reserves of southern Spain: Cong. ġe6l. internat., 11e sess., Compt. rend., pp. 297-306, 1910. 
Iron resources of the Sierra Morena.

[Millions of metric tons of iron.]

\begin{tabular}{|c|c|c|c|}
\hline Province. & Known. & Probable. & Possible. \\
\hline \multirow[t]{2}{*}{$\begin{array}{l}\text { Huelva. } \\
\text { Seville. }\end{array}$} & $\begin{array}{r}93.2 \\
9.0\end{array}$ & $\begin{array}{r}60 \\
9\end{array}$ & 3 \\
\hline & 102.2 & 69 & 9 \\
\hline
\end{tabular}

RANGES OF THE SOUTH COAST. ${ }^{23}$

The ore bodies along the south coast occur in Triassic sediments. They consist of brown ore, hematite, and some magnetite. They occur in the provinces of Malaga, Granada, Almería, and Murcia.

Malaga Province. ${ }^{24}$-In the Marbella and Oja district there are deposits of high-grade magnetite.

In the Archidona, Antequera, and Campillos districts the ore is largely brown ore and hematite, which contains about 55 per cent of iron and little phosphorus.

The known reserve in the Province of Malaga is estimated at $10,000,000$ metric tons of ore containing 5,500,000 metric tons of iron.

Granada Province. ${ }^{25}$-The ore in the Province of Granada occurs near Alquife and in the Cerro del Conjuro. it contains about 50 to 59 per cent of iron and only traces of phosphorus. Some of the ore is so friable that it has to be briquetted.

Iron resources of the Province of Granada, Spain.

[Millions of metric tons.]

\begin{tabular}{|c|c|c|}
\hline & Ore. & Iron. \\
\hline $\begin{array}{l}\text { Known } \\
\text { Possible, }\end{array}$ & $\begin{array}{l}17 \\
10\end{array}$ & $\begin{array}{l}8.5 \\
5.0\end{array}$ \\
\hline
\end{tabular}

Almería Province. ${ }^{26}$-Almería is the largest producer of iron in the provinces on the south coast. Deposits are found at Bedar and Chive, in the Sierra Cobrera and Sierra Alhamilla, and at Bacares, Menas, Macael, Alcudia, Cantas, Olula, and Gergal. Undeveloped bodies occur in the Sierra de Filabres and at Beires.

\footnotetext{
${ }^{23}$ Bulmer, G. H., The Alquife iron-ore mines, in the south of Spain: Inst. Civil Eng. Proc., vol. 159, pp. 312-314, 1904-05. Mallada, L., Datos geologico-mineros de varios criaderos de hierro de Espanta:/Com. mapa geol. Bol., vol. 26, pp. 152-203, 1899.

24 Gillman, F., Malaga magnetites: Inst. Min. Met. Trans. No. 20, p. 447, 1910-11.

2s Yarza, De R., Additional data on iron-ore reserves of southern Spain: Cong. ge6l. internat., 11 sess., Compt. rend., pp. 297-306, 1910.

26 Fabrega, P., A study of the iron-ore deposits of Almerfa; translated by C. V. Haines from Rev. minera, vol. 58, pp. 266-269, 284-288: Min. Jour., vol. 82, pp. 44-45, 78-79, 114-115, 1907. Fircks, F., Utber einige Lagerstätten der Provinz Almería in Spanien: Zeitschr. prakt. Geologic, vol. 14, pp. 142-150, 233-236, 1906. Yarza, De R., Additional data on iron-ore reserves of southern Spain: Cong. geól. internat., 11॰ sess., Compt. rend., pp. 297-306, 1910.
} 
Reports covering the developed districts show that they contain ore carrying from 50 to 57 per cent of iron and little phosphorus.

Iron resources of the Province of Almería, Spain.

[Millions of metric tons.]

\begin{tabular}{|c|c|c|}
\hline & Ore. & Iron. \\
\hline 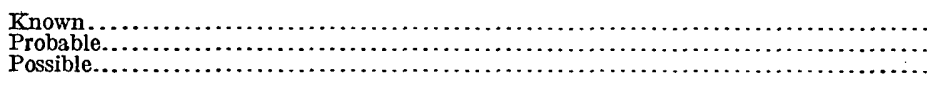 & $\begin{array}{l}45 \\
24 \\
24\end{array}$ & $\begin{array}{l}21 \\
12 \\
12\end{array}$ \\
\hline
\end{tabular}

Murcia Province. ${ }^{37}$-Ore is reported to occur in Triassic rocks near Cartagena, some of it carrying 22 to 26 per cent manganese, and at Lorca, Morata, and Cehegin.

Iron resources of the Province of Murcia, Spain.

[Millions of metric tons.]

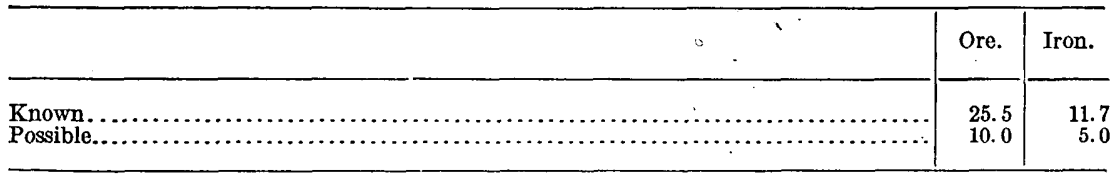

Summary for. south coast ranges.-The resources of the ranges on the south coast are summarized below.

Iron resources of the ranges on the south coast of Spain.

[Millions of metric tons of iron.]

\begin{tabular}{|c|c|c|c|}
\hline Province. & Known. & Probable. & Possible. \\
\hline \multirow[t]{2}{*}{ 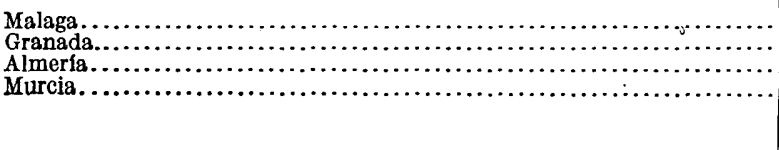 } & $\begin{array}{r}5.5 \\
8.5 \\
24.0 \\
11.7\end{array}$ & $\begin{array}{r}\ldots \ldots \\
\cdots \\
\cdots\end{array}$ & $\begin{array}{r}5 \\
12 \\
5\end{array}$ \\
\hline & 49.7 & ........... & 22 \\
\hline
\end{tabular}

SUMMARY OF THE IRON RESOURCES OF SPAIN.

The quantities of iron in the deposits of Spain are summarized below.

Iron resources of Spain.

[Millions of metric tons of iron. Compare Pl. II, in pocket.]

\begin{tabular}{|c|c|c|c|}
\hline & Known. & Probable. & Possible. \\
\hline 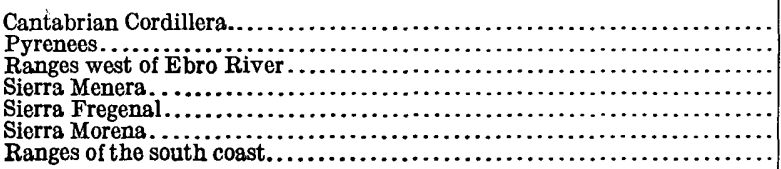 & $\begin{array}{r}110.0 \\
3.6 \\
18.7 \\
65.0 \\
3.9 \\
102.2 \\
49.7\end{array}$ & 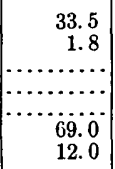 & $\begin{array}{r}82.0 \\
1.6 \\
6.4 \\
24.0 \\
3.9 \\
9.0 \\
22.0\end{array}$ \\
\hline & 353.1 & 116.3 & 148.9 \\
\hline
\end{tabular}

${ }^{27}$ Yarza, De R., Additional data on iron-ore reserves of southern Spain: Cong. geól. internat., 110 sess., Oompt. rend., pp. 303-306, 1910. 


\section{PRODUCTION AND CONSUMPTION.}

The iron ores of Spain are of a quality so high that they have found a large and easy market, and they have therefore been exploited heavily, so that, as the accompanying chart (fig. 8) suggests, their production may have reached its maximum rate, but on the other hand, the reserves are so large that the present production of

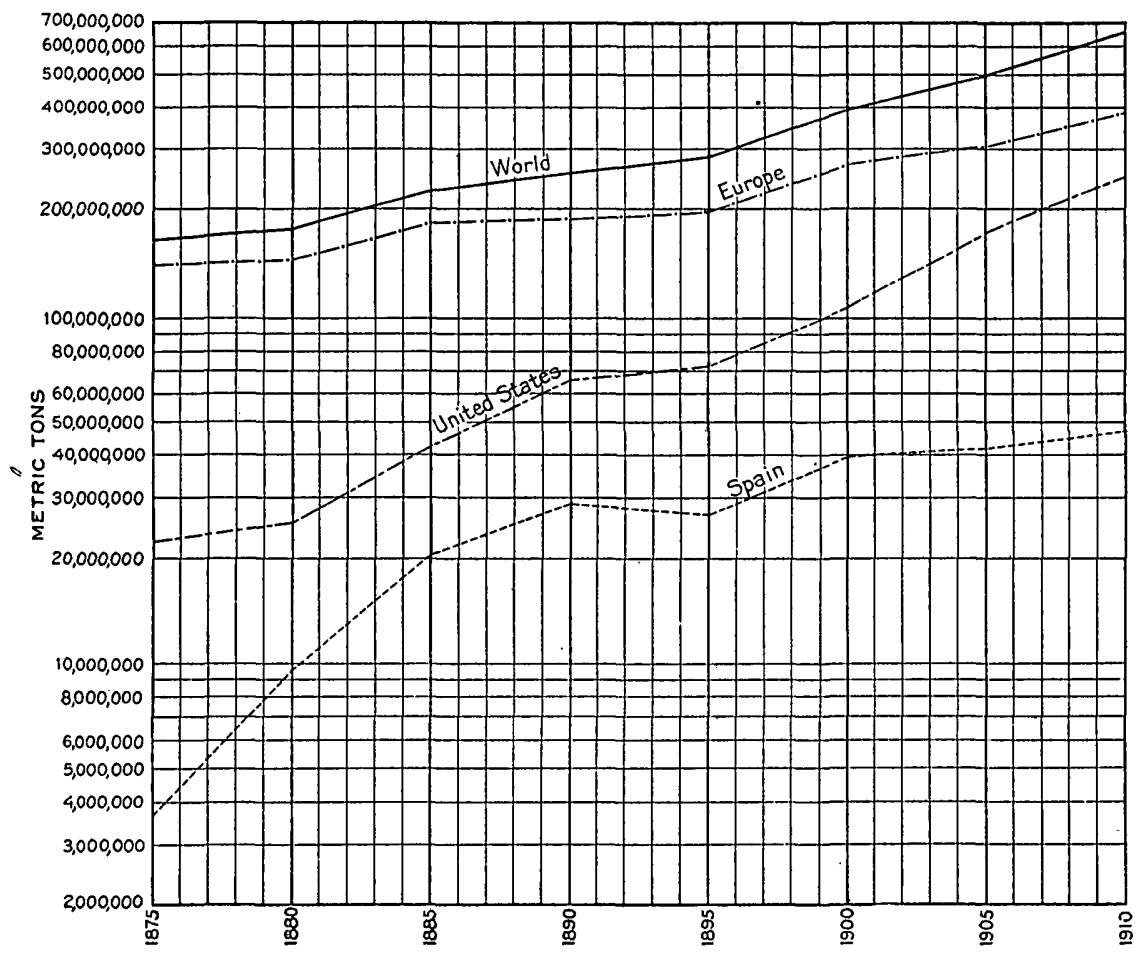

Figure 8.-Ratio chart showing iron ore produced during five-year periods ending 1875 to 1910 in Spain, Europe, the United States, and the world. This chart and similar ones showing the production of iron ore in other countries affords a ready comparison of the rates at which iron mining has increased in the soveral countries. The figures are so plotted that in all parts of the chart guide lines of like slope indicate like rates of increase or decrease, and steeper slopes correspond with higher rates of change.

$8,000,000$ to $10,000,000$ metric tons a year will be continued for at least a few decades. In 1913 the production of iron ore in Spain was 9 per cent of the total production of Europe.

Most of the ore produced has heretofore been taken from deposits near tidewater, but a very considerable part of it has been taken from scattered deposits, as the following table shows. 
Iron ore produced in Spain, 1912-1915.

[Metric tons.]

\begin{tabular}{|c|c|c|c|c|}
\hline Province. & 1912 & 1913 & 1914 & 1915 \\
\hline 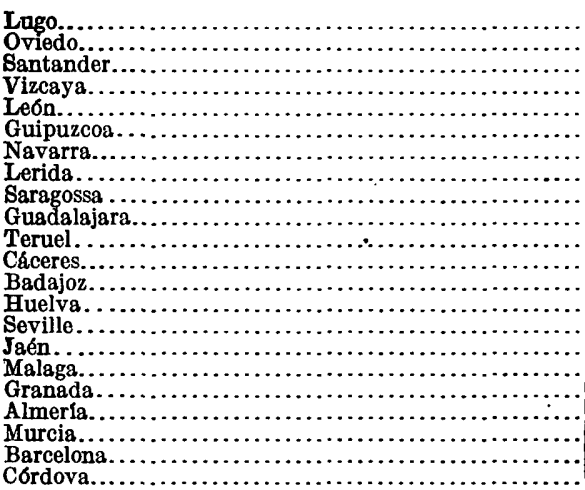 & \begin{tabular}{r}
272,600 \\
184,467 \\
$1,272,835$ \\
$3,514,368$ \\
1,149 \\
82,837 \\
6,002 \\
1,814 \\
\hdashline 256,292 \\
676,840 \\
$\cdots 90,675$ \\
156,831 \\
318,805 \\
43,830 \\
55,620 \\
212,242 \\
$1,133,568$ \\
801,435 \\
34,695 \\
120
\end{tabular} & $\begin{array}{r}290,300 \\
186,192 \\
1,278,087 \\
3,864,593 \\
\times 92,718 \\
8,246 \\
19,500 \\
20,460 \\
278,528 \\
662,307 \\
4,825 \\
94,308 \\
211,942 \\
368,894 \\
47,052 \\
56,850 \\
234,719 \\
1,350,247 \\
770,540 \\
17,360\end{array}$ & $\begin{array}{r}211,650 \\
126,585 \\
1,076,613 \\
2,618,149 \\
\ldots . . . . \\
49,304 \\
4,419 \\
11,000 \\
32,438 \\
163,710 \\
375,360 \\
872 \\
52,581 \\
120,292 \\
293,232 \\
16,407 \\
44,280 \\
185,812 \\
1,003,314 \\
422,179 \\
11,768\end{array}$ & $\begin{array}{r}24,690 \\
121,383 \\
678,085 \\
2,674,638 \\
\ldots \ldots 2,856 \\
7,923 \\
6,500 \\
8,533 \\
54,786 \\
379,907 \\
\ldots \ldots .96 \\
16,052 \\
38,092 \\
268,832 \\
11,080 \\
14,694 \\
136,672 \\
915,679 \\
234,437 \\
\ldots \ldots \ldots\end{array}$ \\
\hline
\end{tabular}

The production from Vizcaya and Santander will probably decrease; that of the other Provinces will probably increase.

Very little pig iron was produced in Spain in 1913, a fact shown by her small ore consumption, which was only 1 per cent of the total consumption in Europe although there is consiäerable coal in Spain.

\section{PORTUGAL. ${ }^{28}$}

\section{DISTRIBUTION, CHARACTER, AND EXTENT OF THE DEPOSITS.}

The general distribution of the deposits of iron ore in Portugal is shown on Plate II (in pocket) and on the sketch map (fig. 9). The available descriptions of the deposits are lamentably lacking in mineralogic detail, and the data at hand are insufficient to enable any one to form a judgment as to the correctness of the classification adopted.

Moncorvo.-The most extensive deposits are those of Moncorvo, in the Trazos Montes district, in northwestern Portugal. They are described as concordant lenses in schists and are classed by J. P. Gomes ${ }^{29}$ as metamorphosed sedimentary deposits. The ore contains 40 to 60 per cent of iron, 4 to 7 per cent of silica, and little phosphorus and sulphur.

${ }^{28}$ Gomes, J. P., Die Eisenerzvorräte von Portugal: The iron-ore resources of the world (11th Internat. Geol. Congress), vol. 1, pp. 85-93, Stockholm, 1910. Ahlburg, J., Die nutzbaren Mineralien Spaniens und Portugals: Zeitschr. prakt. Geologie, vol. 15, pp. 196 et seq., 1907.

20 Op. cit., pp. 88-89. 
Iron resources of Moncorvo, Portugal.

[Millions of metric tons.]

\begin{tabular}{|c|c|c|}
\hline & Ore. & Iron. \\
\hline 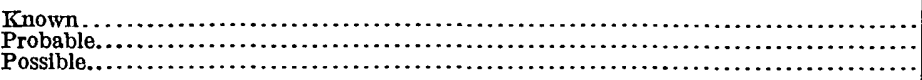 & $\begin{array}{l}10 \\
10 \\
25\end{array}$ & $\begin{array}{r}5.0 \\
5.0 \\
12.5\end{array}$ \\
\hline
\end{tabular}

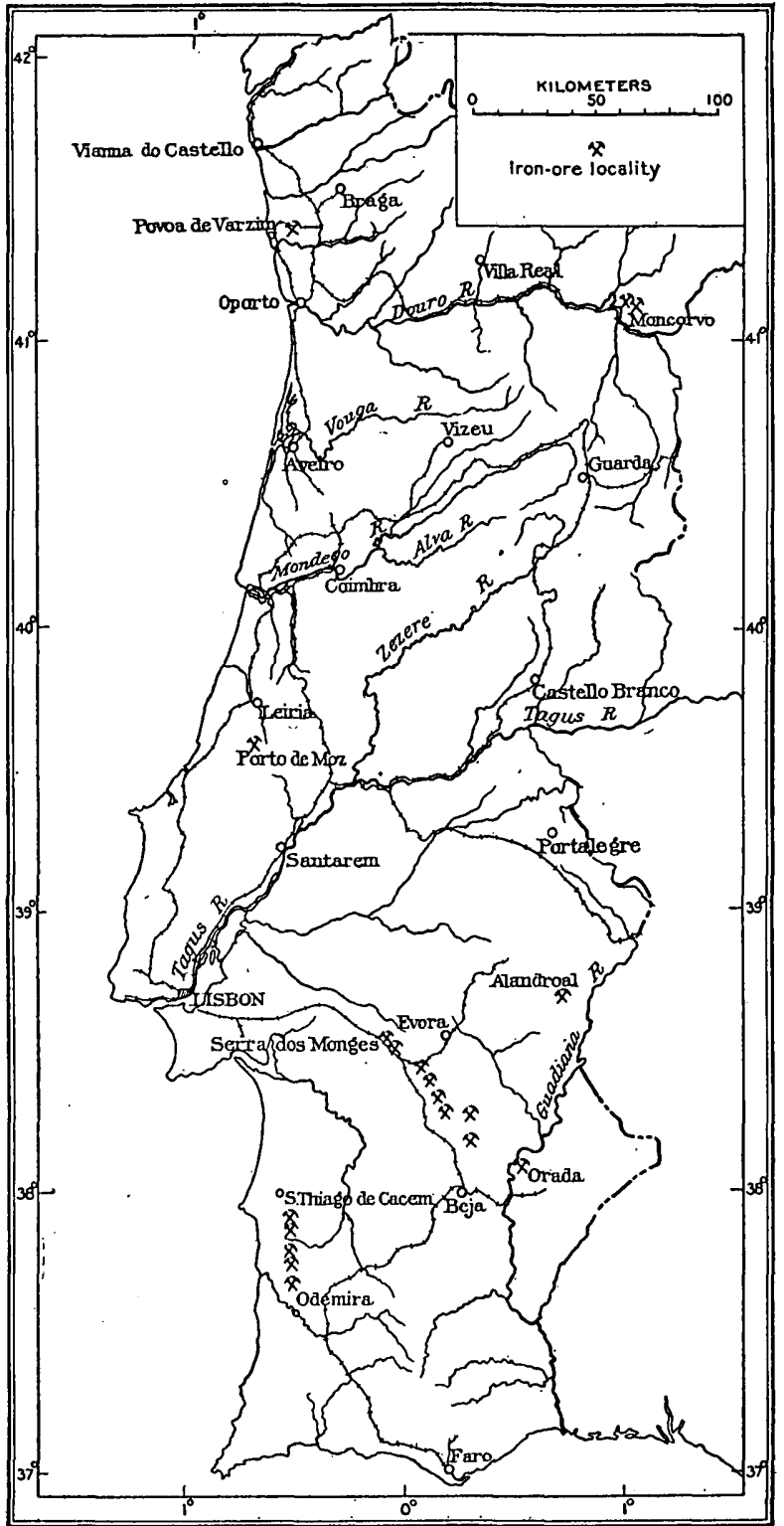

FIGURE 9.-Mapshowing deposits of iron ore in Portugal. (From "The iron-ore resources of the world.") 
Porto de Moz.- - In west-central Portugal, at Porto de Moz, there are veins of iron ore in Jurassic limestone. The sorted ore contains 55 to 60 per cent of iron. The reserves are small.

Iron resources at Porto de Moz, Portugal.

[Millions of metric tons.]

\begin{tabular}{|c|c|c|}
\hline & Ore. & Iron. \\
\hline $\begin{array}{l}\text { Known } \\
\text { Probable,..., }\end{array}$ & $\begin{array}{l}1 \\
2\end{array}$ & $\begin{array}{l}0.6 \\
1.1\end{array}$ \\
\hline
\end{tabular}

Serra dos Monges.-In central Alemtejo, in the Serra dos Monges, there are lenses of brown ore in crystalline schists near diorites. J. P. Gomes interprets them as metamorphosed sediments. The ore contains 55 to 63 per cent of iron, 0.01 to 0.02 per cent of phosphorus, 0.3 to 0.5 per cent of sulphur, and 3 to 7 per cent of silica.

Iron resources of central Alemtejo, Portugal.

[Millions of metric tons.]

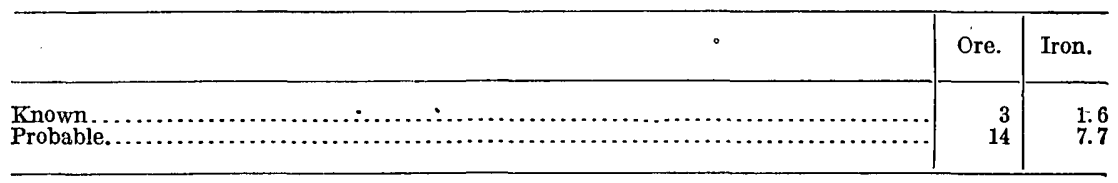

São Thiago de Cacem and Odemira.-Shallow deposits of superficial manganiferous iron ore are found in southwestern Portugal. They are peculiar in that their greatest extent lies across the strike of the metamorphic rocks on which they rest. They contain 30 to 40 per cent of iron and 20 to 30 per cent of manganese and are rather siliceous.

Iron resources of southwestern Portugal.

[Millions of metric tons.]

\begin{tabular}{|c|c|c|}
\hline & Ore. & Iron. \\
\hline 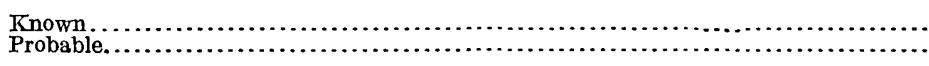 & $\begin{array}{l}3 \\
7\end{array}$ & $\begin{array}{l}1.0 \\
2.4\end{array}$ \\
\hline
\end{tabular}

Summary.-The quantities of iron in the deposits of Portugal are summarized below.

Iron resources of Portugal.

[Millions of metric tons of iron.]

\begin{tabular}{|c|c|c|c|}
\hline & Known. & Probable. & Possible. \\
\hline 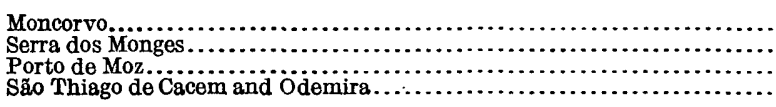 & $\begin{array}{r}5.0 \\
1.6 \\
1.6 \\
1.0\end{array}$ & $\begin{array}{l}5.0 \\
7.7 \\
1.1 \\
2.4\end{array}$ & $\begin{array}{l}12.5 \\
\cdots \ldots \ldots . . \\
\cdots \cdots \cdots \cdots\end{array}$ \\
\hline & 8.2 & 16.2 & 12.5 \\
\hline
\end{tabular}




\section{PRODUCTION AND CONSUMPTION.}

Portugal has no iron industry. Her production of iron ore in 1913 amounted to about 50,000 tons, all of which was exported.

\section{UNITED KINGDOM.}

The iron ores of the United Kingdom (Pl. IV, in pocket) have been studied thoroughly by geologists whose reports appear in publications of the Geological Survey of Great Britain issued during the nineteenth century. These reports establish the existence of an enormous amount of iron-bearing material in the United Kingdom, but they leave considerable doubt as to the amount of it that should now be classified as ore. In compiling the information on the United Kingdom for this report reliance was placed chiefly on the summaries worked out under the direction of Henry Louis ${ }^{30}$ and on the summary of reserves published in $1917 .^{31}$

Eckel $^{32}$ has discussed the British ore reserves, and De Launay ${ }^{33}$ has prepared summaries of their geology.

\section{DISTRIBUTION, CHARACTER, AND EXTENT OF THE DEPOSITS.}

The distribution of the British ores is best shown on a geologic map. In fact a map showing the Jurassic and the Carboniferous formations in Great Britain would include all the valuable deposits. The deposits will therefore be described in groups according to the geologic horizon in which they occur.

\section{MESOZOIC ORES.}

Jurassic sediments that contain iron ores are exposed in a belt whose north end is marked by a line extending from Scarborough to Whitby, on the east coast, and which runs almost due south to Northampton and swings westward to the Bristol Channel.

Cleveland. ${ }^{34}$-At the north end of the Jurassic belt are the deposits of the Cleveland district, shown in figure 10, which are the largest producers of iron ore in Great Britain. The ore is an oolitic siderite ${ }^{35}$ containing some glauconite. It is intercalated between beds of shale and sandstone in six well-defined beds, which range in thickness from 1 to 12 feet. The only bed exploited is the "main" seam, which is from 6 to 12 feet thick.

${ }^{80}$ Louis, Henry, The iron-ore resources of the United Kingdom of Great Britain and Ireland: The ironoreresources of the world (11th Internat. Geol. Cong.), vol. 2, pp. 623-641, Stockholm, 1910. Department of Scientific and Industrial Research, Advisory Council, Report on the sources and production of iron and other metalliferous ores used in the iron and steel industry, London, 1918.

si Strahan, A. (Director), Summary of progress of the Geological Survey of Great Britain, pp. 6-7, London, 1917.

82 Eckel, E. C., Iron ores, pp. 315-322, McGraw-Hill Book Co., 1914.

88 Launay, L. de, Gites minéraux et metallifères, 3 vols., Paris, Ch. Beranger, 1913.

84 Louis, Henry, op. cit., vol. 2, pp. 630-633.

${ }^{85}$ Launay, L. de, op. cit., vol. 2, p. 484. 
The ore carries a little over 30 per cent of iron, 8 to 10 per cent of silica, and 1 to 1.5 per cent of phosphoric acid, and the calcined ore has an iron content of about 43 per cent.

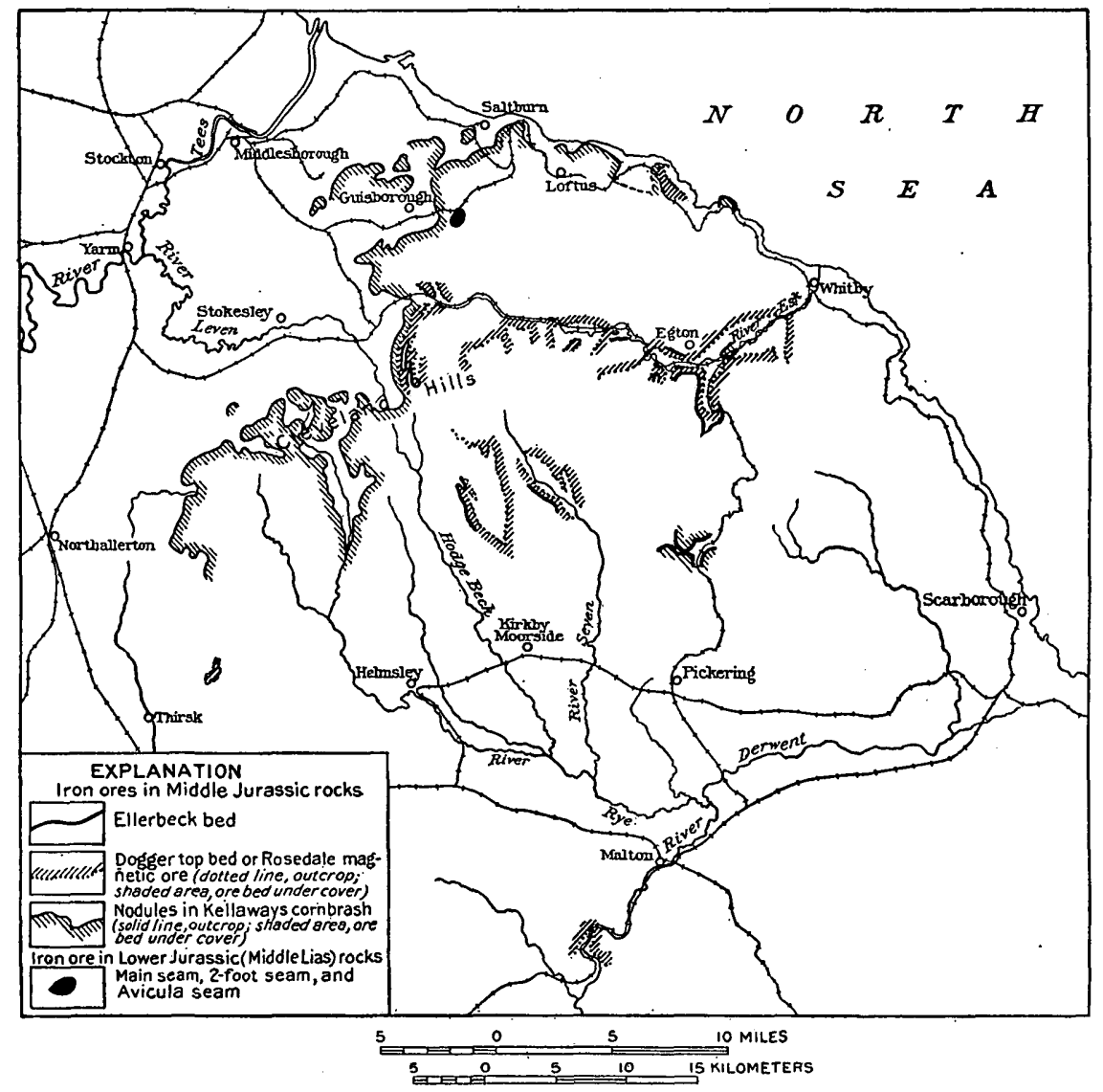

FTavRE 10.-Map of the Cleveland iron-ore district, England. (From "The iron-ore resources of the world.")

Iron resources of the Cleveland district, England.

[Millions of metric tons.]

\begin{tabular}{|c|c|c|}
\hline & Ore. & Iron. \\
\hline $\begin{array}{l}\text { Known } \\
\text { Probable. } \ldots \ldots \ldots \\
\text { Possible } \ldots \ldots \ldots\end{array}$ & $\begin{array}{l}190 \\
190 \\
400\end{array}$ & $\begin{array}{r}57 \\
57 \\
120\end{array}$ \\
\hline
\end{tabular}

Lincoln..$^{36}$ - In Lincoln (see Pl. V) there are several beds of carbonate ores, from which brown ores that lie near the surface, in the Mesozoic strata, have been derived. The most valuable are the Frodingham beds, which average 12 feet in thickness and are found in an area covering 12 square miles. Another deposit in Lincoln, the

${ }^{86}$ Louis, Henry, op. cit., vol. 2, pp. 634-635. 
Marlstone bed, is of minor importance. It is extensively developed in Leicester.

The ore contains only 23 per cent of iron but is easy to mine and is being drawn upon more and more. The ore in the smaller seams is of higher grade.

Iron resources of Lincoin, England.

[Millions of metric tons.]

\begin{tabular}{|c|c|c|}
\hline & Ore. & Iron. \\
\hline 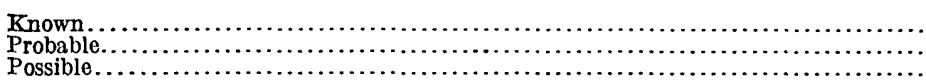 & $\begin{array}{l}250 \\
250 \\
450\end{array}$ & $\begin{array}{r}67 \\
75 \\
135\end{array}$ \\
\hline
\end{tabular}

The apparent higher grade of the "probable" and "possible" reserves is due to the fact that a greater proportion of the thinner, higher-grade seams has been put in those classes.

Leicester. ${ }^{37}$ - The Marlstone bed is better developed in Lincoln than in Leicester. It is known for a distance of 12 miles and probably extends 20 miles. The ore is of the same type as that in Lincoln but contains more iron.

Iron resources of Leicester, England.

[Millions of metric tons.]

\begin{tabular}{|c|c|c|}
\hline - & Ore. & Iron. \\
\hline 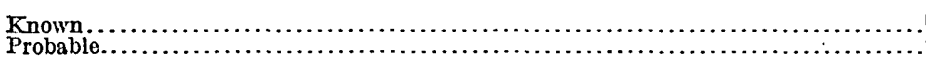 & $\begin{array}{l}62 \\
38\end{array}$ & $\begin{array}{l}18.6 \\
11.4\end{array}$ \\
\hline
\end{tabular}

No "possible" ore has been estimated, because there is not sufficient information on which to base a figure.

Rutland and Oxford. ${ }^{38}-\mathrm{A}$ deposit known as the Northampton bed, which is of large extent and value, in Northampton, occurs also in Oxford, where it is from 4 to 13 feet thick and furnishes considerable ore similar to that of Lincoln and Leicester. The reserve is very considerable and lies mostly in Oxford.

Iron resources of Rutland and Oxford, England.

[Millions of metric tons.]

\begin{tabular}{|c|c|c|}
\hline & Ore. & Iron. \\
\hline 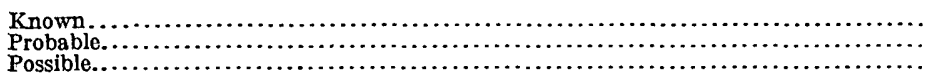 & $\begin{array}{r}123 \\
86 \\
300\end{array}$ & $\begin{array}{l}35.0 \\
21.5 \\
75.0\end{array}$ \\
\hline
\end{tabular}

${ }^{87}$ Louis, Henry, op. cit., vol. 2, pp. 635-636.

${ }^{38}$ Idem, p. 636. 
Northampton. ${ }^{39}$-The beds of carbonate ore in the Mesozoic rocks of Northampton (Pl. V) are of great extent and of good grade. They are known over an area 100 miles long and as much as 20 miles wide. The estimates made run up to $1,000,000,000$ metric tons, but the figures below are believed to be more reasonable.

Iron resources of Northampton, England.

[Millions of metric tons.]

\begin{tabular}{|c|c|c|}
\hline & Ore. & Iron. \\
\hline $\begin{array}{l}\text { Known. } \\
\text { Probable. } \\
\text { Possible.. }\end{array}$ & $\begin{array}{l}100 \\
100 \\
300\end{array}$ & $\begin{array}{l}32 \\
32 \\
96\end{array}$ \\
\hline
\end{tabular}

Inverness. ${ }^{40}$ - Recent developments on the island of Raasay, east of northern Scotland, have disclosed deposits of oolitic siderite similar to the deposits of the Cleveland district in age, type, and mode of occurrence.

Iron resources of Inverness, Scotland.

[Millions of metric tons.]

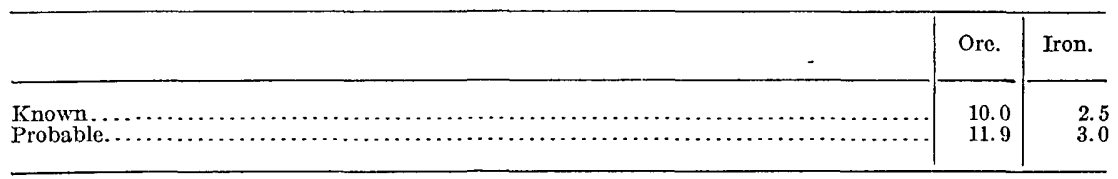

Summary of iron in Mesozoic ores.

[Millions of metric tons of iron.]

\begin{tabular}{l}
\hline \\
Cleveland......... Known.
\end{tabular}

CARBONIFEROUS ORES. ${ }^{41}$

Immense quantities of clay ironstone ores are associated with the coal measures that crop out from Newcastle almost to Gloucester and that appear in outliers in Scotland and South Wales, and some of these ores, such as those of Northumberland, are in the Carboniferous but not in the coal measures. In 1910 Louis estimated that there was a potential reserve of $34,000,000,000$ tons of this ore, $15,000,000,000$ tons of it in South Wales alone.

${ }^{39}$ Louis, Henry, op. cit., vol. 2, pp. 633-634.

10 Department of Scientific and Industrial Research, Advisory Council, Report on the sources and production of iron and other metalliferous ores used in the iron and steel industry, p. 32, London, 1918.

41 Louis, Henry, op. cit., vol, 2, pp. 637-641. 


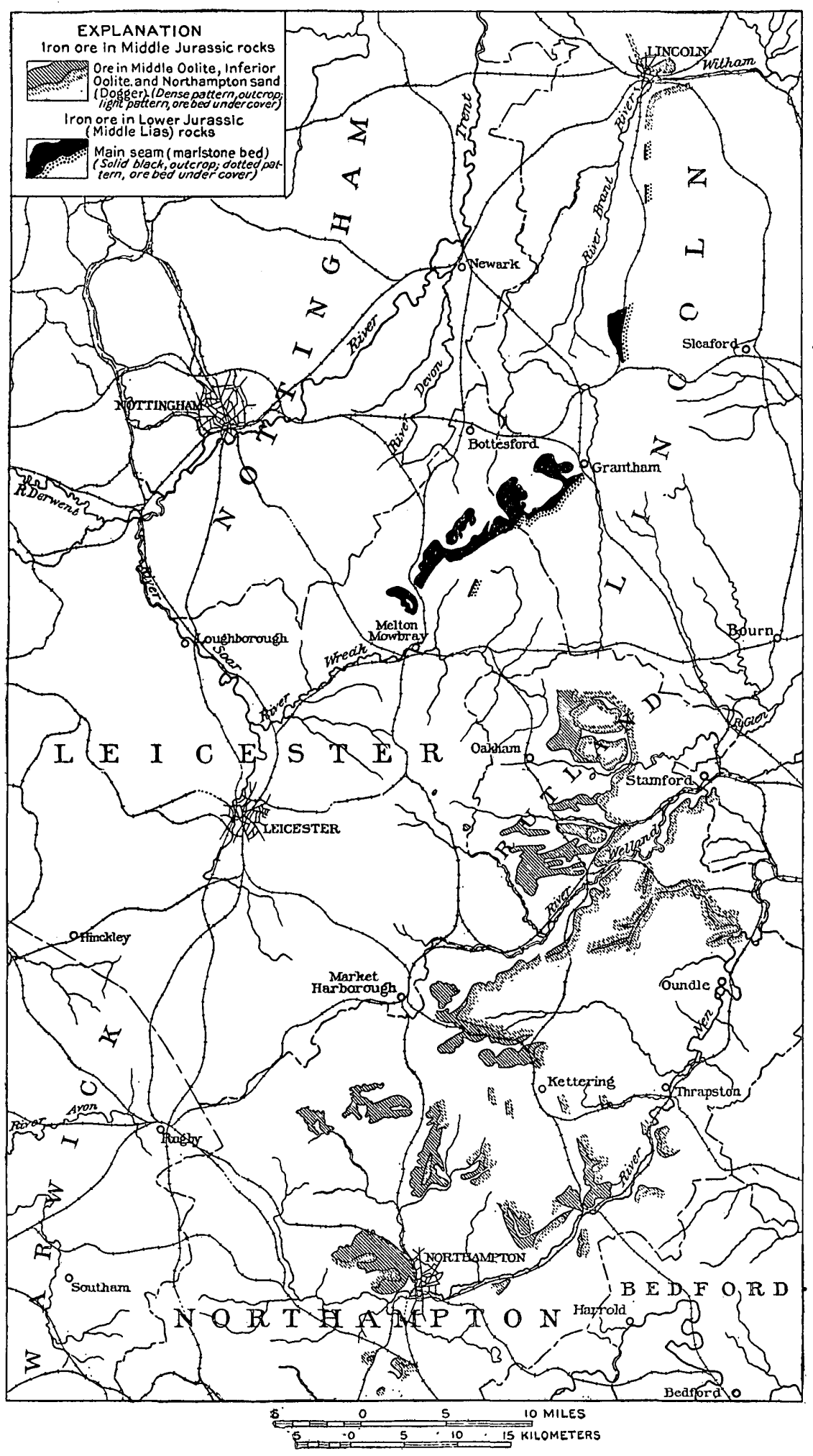

MAP OF THE IRONSTONE DISTRICTS OF NORTHAMPTON AND LINCOLN, ENGLAND. 
From 1880 to 1915 the production of ores of this type fell from $5,244,000$ long tons to $1,235,000$ long tons. In 1880 it formed 29 per cent of that of the United Kingdom; in 1915 it had dropped to 9 per cent. If there were no future reduction in the mining of this ore the reserve of $34,000,000,000$ tons which Louis assigns to the Carboniferous beds would last 25,000 years.

Apparently the economic trend has been to use these ores in continually decreasing quantities, and the possibility that they will be utilized to a point nearing exhaustion is growing less. In this study, therefore, the estimates of Louis have been greatly reduced.

Carboniferous iron ores in Great Britain.

[Millions of metric tons.]

\begin{tabular}{|c|c|c|c|c|c|c|}
\hline & \multicolumn{2}{|c|}{ Known. } & \multicolumn{2}{|c|}{ Probable. } & \multicolumn{2}{|c|}{ Possible. } \\
\hline & Ore. & Iron. & Ore. & Iron. & Ore. & Iron. \\
\hline \multirow{4}{*}{ 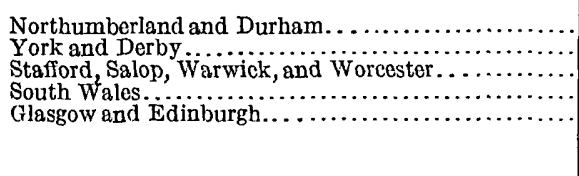 } & 35.0 & 10.5 & 65.0 & 19.5 & \multirow{3}{*}{$\begin{array}{r}200 \\
200 \\
800 \\
1,500 \\
400\end{array}$} & \multirow{3}{*}{$\begin{array}{r}60 \\
60 \\
296 \\
450 \\
128\end{array}$} \\
\hline & 200.0 & 74.0 & 400.0 & 148.0 & & \\
\hline & 7.7 & $\dddot{2.5}$ & 76.6 & $\dddot{24.5}$ & & \\
\hline & 242.7 & 87.0 & 541.6 & 182.0 & 3,100 & 994 \\
\hline
\end{tabular}

\section{HEMATITE AND MAGNETITE ORES.}

England still has a small supply of high-grade Bessemer ores, from which she produced about 1,500,000 tons in 1915 .

The reserves of high-grade hematite and magnetite ores are tabulated below, in millions of metric tons of metallic iron:

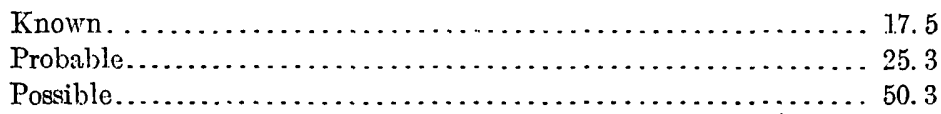

Cumberland and Lancaster. ${ }^{42}$-In Cumberland and Lancaster, at the localities shown in figure 11, hematite ores occur as a replacement of Carboniferous limestone. They average more than 50 per cent of iron and contain very little phosphorus, so that for metallurgic use they are very desirable.

Iron resources of Cumberland and Lancaster, England.

[Millions of metric tons.]

\begin{tabular}{|c|c|c|}
\hline & Ore. & Iron. \\
\hline $\begin{array}{l}\text { Known } \\
\text { Probable } \\
\text { Possible } \ldots \ldots \ldots\end{array}$ & $\begin{array}{r}35 \\
50 \\
100\end{array}$ & $\begin{array}{l}17.5 \\
25.0 \\
50.0\end{array}$ \\
\hline
\end{tabular}

42 Louis, Henry, op. cit., vol. 2, pp. 625-626. $15945^{\circ}-21-$ Bull. $706-4$ 
Cornwall and Devon.-The lodes of red hematite of Cornwall and the deposits of Devon, which are apparently magnetite that replaced limestone, are of excellent grade. The reserve is very small,

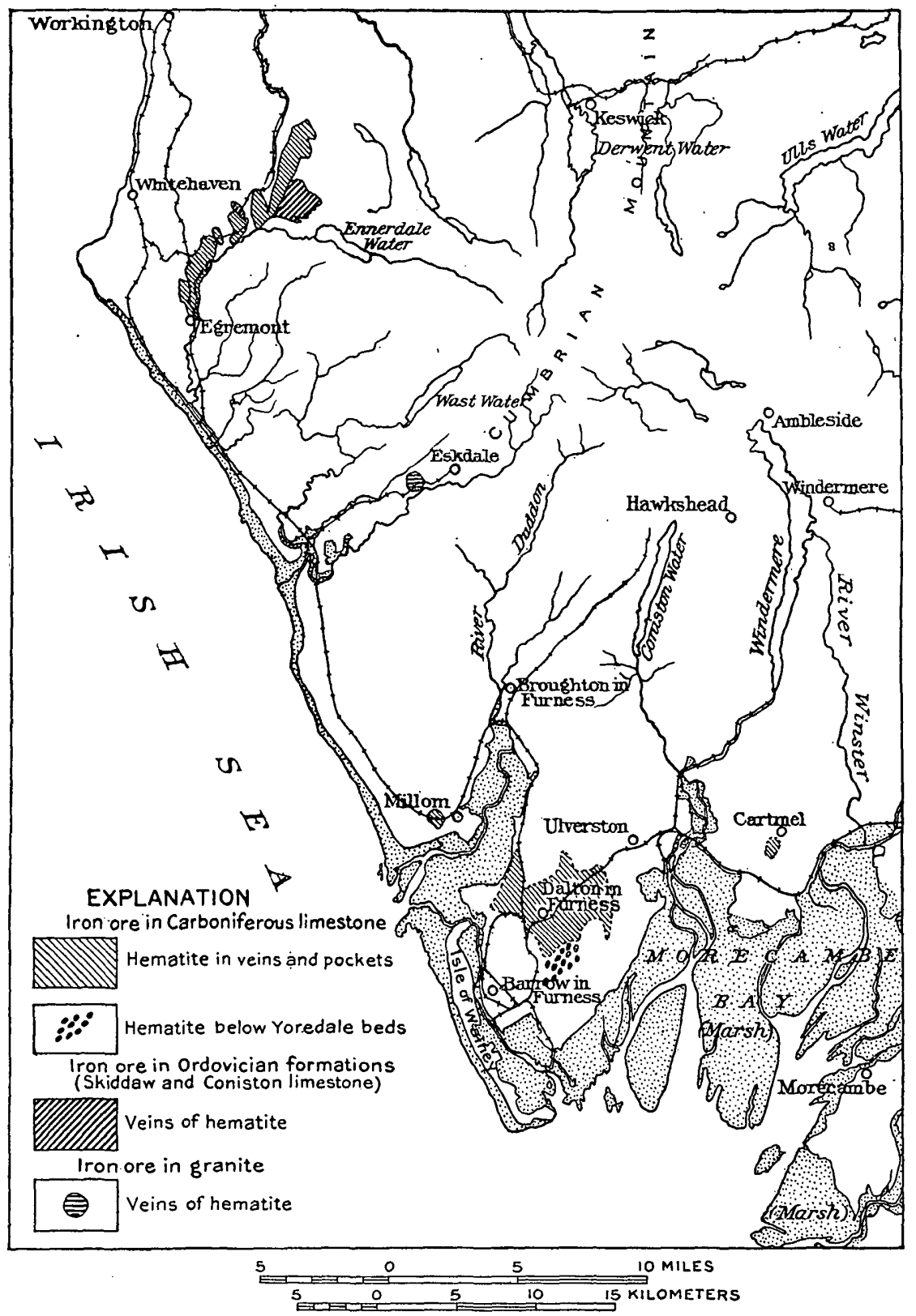

FraURE 11.-Map showing distribution of the hematite deposits of Cumberland and Lancaster, England. (From "The iron-ore resources of the world.")

the "probable" and "possible" class including only about 250,000 tons of iron. 
MISCELLANEOUS DEPOSITS.

Gloucester. ${ }^{43}$-Pockets of brown ore averaging 36 per cent of iron are found in Carboniferous limestones in Gloucester.

Iron resources of Gloucester, England.

[Millions of metric tons.]

\begin{tabular}{|c|c|c|}
\hline & Ore. & Iron. \\
\hline 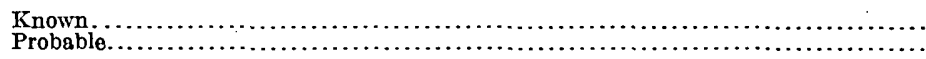 & $\begin{array}{l}2.5 \\
3.0\end{array}$ & $\begin{array}{l}0.9 \\
1.1\end{array}$ \\
\hline
\end{tabular}

Somerset. ${ }^{44}$-In Somerset, at Brandon Hills and Withyford, there are veins of spathic ore that were mined up to 1914. The production has stopped and no estimate is made of the reserves.

North Wales (Carnarvon). ${ }^{45}$-Pisolitic ores in the Cambrian rocks of North Wales supply about 20,000 tons of ore a year. The reserves have not been considered worth estimating.

Wilts and Kent. ${ }^{46}$-In the Cretaceous rocks of Kent and Wilts there are bedded oolitic ores. They furnished about 20,000 tons in 1915 .

Iron resources of Wilts and Kent.

[Millions of metric tons.]

\begin{tabular}{|c|c|c|}
\hline & Ore. & Iron. \\
\hline 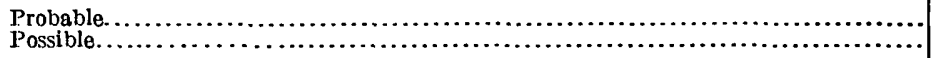 & $\begin{array}{r}148.5 \\
5.5\end{array}$ & $\begin{array}{r}46 \\
2\end{array}$ \\
\hline
\end{tabular}

Ireland. ${ }^{47}$-Ireland produced 39,000 tons of iron ore in 1915, most of it from pisolitic residual ores of County Antrim. Clay ironstones are found near Lough Allen and in Kilkenny County. Magnetite is found at Ballycog. The reserves of ore are not large and have not been estimated.

Summary of the miscellaneous deposits.-The iron content of the miscellaneous deposits is summarized below.

Iron resources of Gloucester, Wilts, and Kent.

[Millions of metric tons of iron.]

\begin{tabular}{|c|c|c|c|}
\hline & Known. & Probable. & Possible. \\
\hline \multirow[t]{2}{*}{ 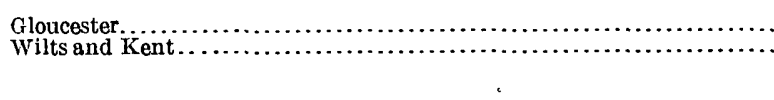 } & $\begin{array}{r}0.9 \\
0.6 .\end{array}$ & $\begin{array}{r}1.1 \\
46.0\end{array}$ & $\ddot{2}$ \\
\hline & .9 & 47.1 & 2 \\
\hline
\end{tabular}

43 Department of Scientific and Industrial Research, Advisory Council, Report on the sources and production of iron and other metalliferous ores used in the iron and steel industry, p. 24, London, 1918.

4 Idem, p. 25.

45 Idem, p. 30.

40 Idem, p. 23.

"7 Idem, pp. 32-33. 


\section{SUMMARY OF IRON RESOURCES OF THE UNITED KINGDOM.}

The iron resources of the United Kingdom, classified as they have been considered here, are summarized below.

Iron resources of the United Kingdom.

[Millions of metric tons of iron. Compare PI. IV, in pocket.]

\begin{tabular}{|c|c|c|c|}
\hline . & Known. & $\begin{array}{l}\text { Prob- } \\
\text { able. }\end{array}$ & Possible. \\
\hline \multirow[t]{2}{*}{ 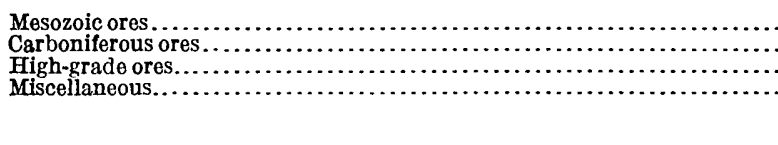 } & $\begin{array}{r}212.1 \\
87.0 \\
17.5 \\
.9\end{array}$ & $\begin{array}{r}199.9 \\
192.0 \\
25.3 \\
47.1\end{array}$ & $\begin{array}{r}426.0 \\
994.0 \\
50.3 \\
2.0\end{array}$ \\
\hline & 317.5 & 464.3 & $1,472.3$ \\
\hline
\end{tabular}

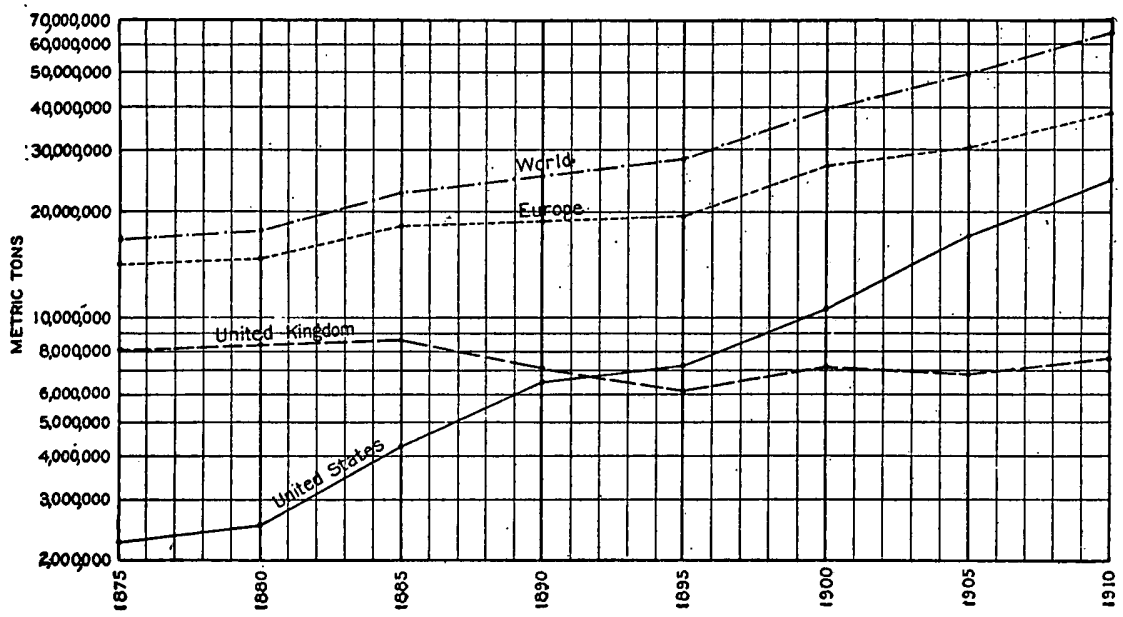

Figure 12.-Ratio chart showing iron ore produced during five-year periods ending 1875 to 1910 in the United Kingdom, Europe, the United States, and the world. '(See explanation of fig. 8, p. 41.)

\section{PRODUCTION AND CONSUMPTION.}

In 1913 the United Kingdom stood fourth in the list of producers of iron ore and third among the producers of pig iron. Until 1890 she held first place, but in that year the United States passed her in the output of both iron ore and pig iron. In 1896 the production of ore and in 1903 the production of pig iron of the German Customs Union passed that of the United Kingdom, and in 1911 France took third place in the production of ore.

As figure 12 shows, the production of iron ore in the United Kingdom since 1870, though almost constant, has declined slightly. Of all European countries producing over 1,000,000 tons of ore in 1913 the United Kingdom is the only one that shows a decline in that year.

Figure 13 is a more comprehensive tabulation of the history of the iron industrv in the United Kingdom. It shows that though her pro- 
duction of iron ore has fallen off her imports have risen at a rate so high that her consumption has increased rather steadily though very gradually. To show how Great Britain compares with the two other countries having a large iron industry, the production of pig iron in the United Kingdom, Germany, and the United States was plotted on one diagram (fig. 14), which shows that her chief rivals were rapidly leaving Great Britain behind when the war broke out.

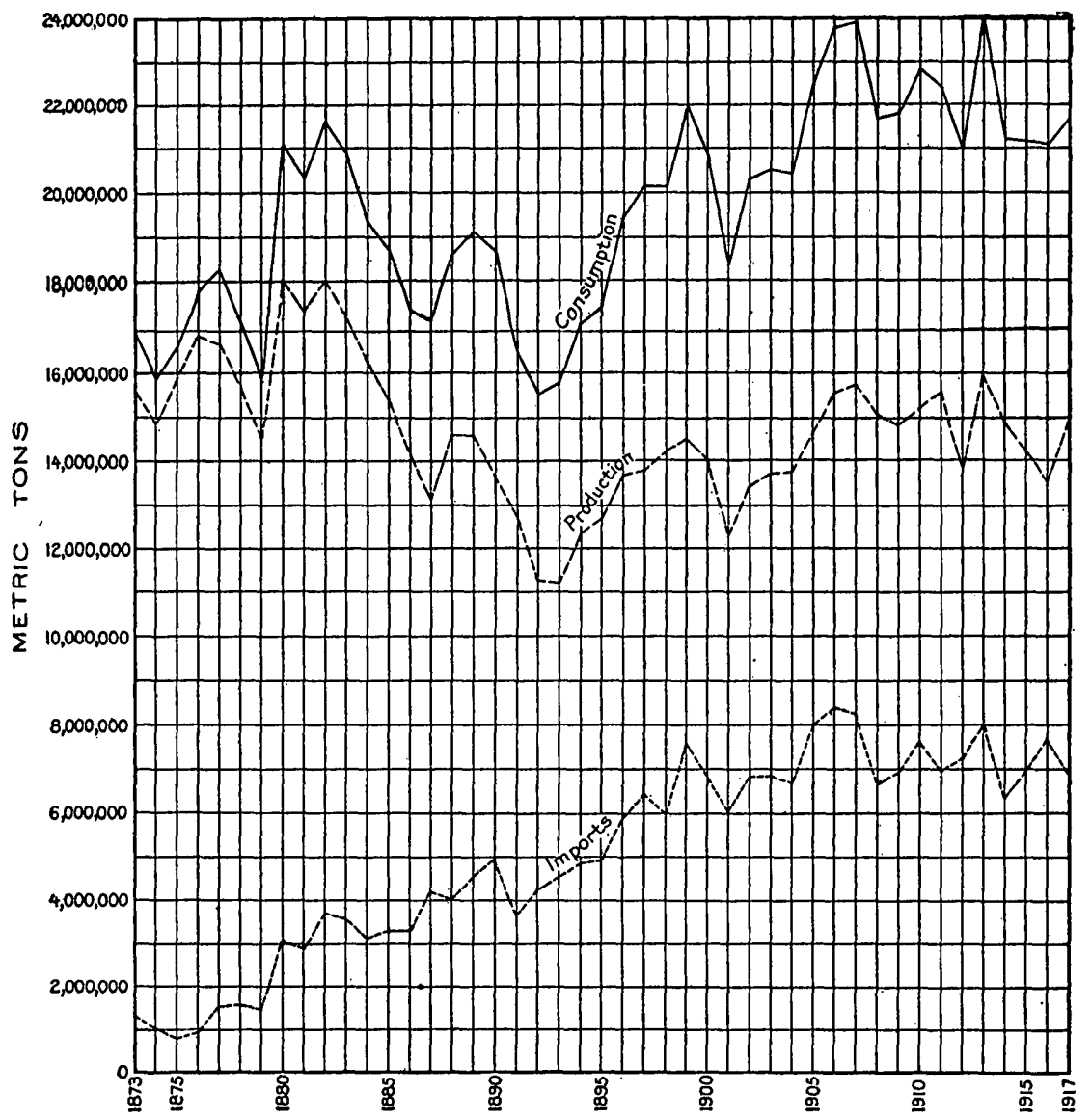

FIGURE 13. - Chart showing iron ore produced, imported, and consumed in the United Kingdom, 18731917. The average annual exports amount to 10,000 tons.

The war severed the bond between Lorraine iron ore and German coal, a bond which had caused the rise in the French and German production of iron and iron ore and which is so patently to the advantage of both France and Germany that it will almost inevitably be repaired. But for some time both Great Britain and the United States probably will be free to increase their iron industry without fear of a serious rival. 


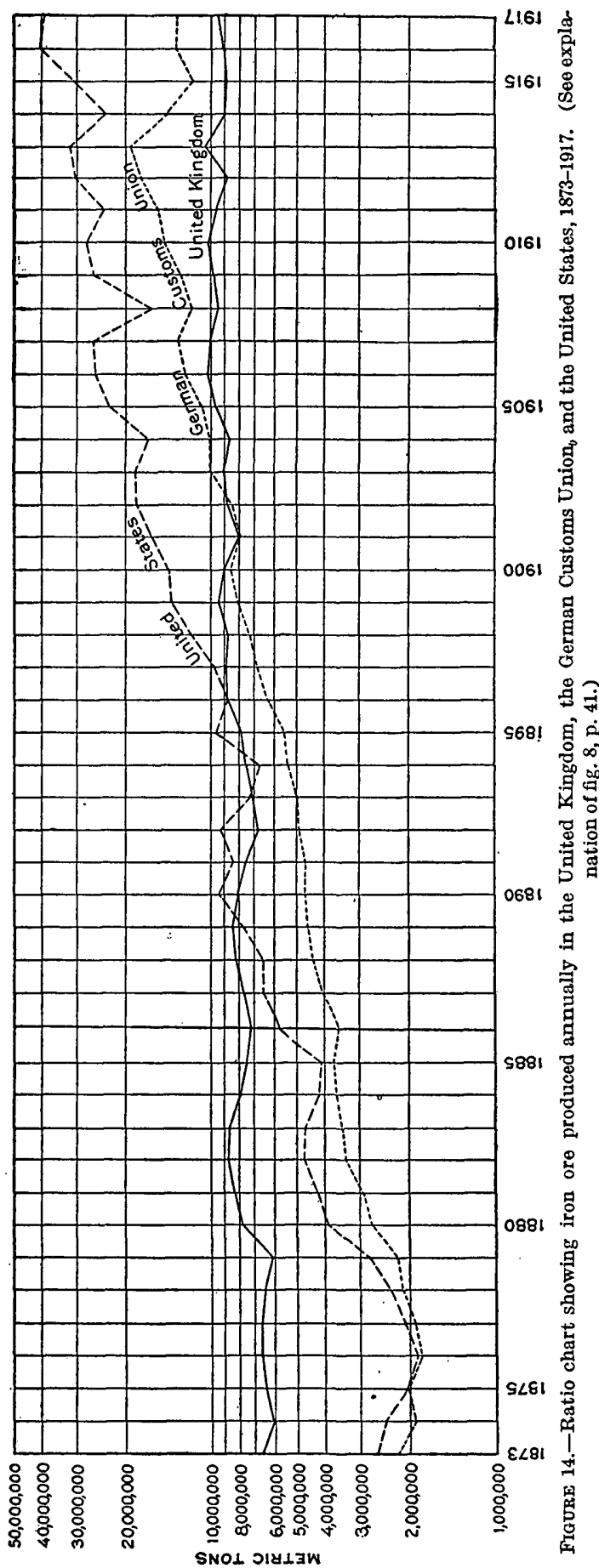


In 1913 the United Kingdom produced 15.5 per cent of the European production of iron ore and consumed 21.5 per cent of the European consumption. (See fig. 4, p. 26.) She is a heavy importer of ore, especially of Spanish ore, and the leaders of her iron industries have saf eguarded the future by gaining large holdings of ore in Brazil. As her coal resources are very large her position in the iron industry is assured for many generations.

An ore reserve that may have some influence on the British iron industry is found in Spitzbergen, where there are said to be huge workable deposits, though it has not yet been proved that they are workable. The ownership of the island is also in doubt, a fact indicated by Sir Martin Conway ${ }^{48}$ in a paper read at a meeting of the London Geographical Society, and in the subsequent discussion.

\section{FRANCE.}

\section{DISTRIBUTION, CHARACTER, AND EXTENT OF THE DEPOSITS.}

Before the war there was some question as to whether France or Newfoundland ranked next to the United States in resources of available iron ore, but since the lost provinces have been restored to France that question is settled beyond doubt. France now stands second in the world and is preeminent in Europe with more than four times the resources of any other European nation. (See Pl. VI, in pocket.) She controls politically all the ore in the Lorraine Basin except the small part of it that lies in Luxemburg and has large deposits in Normandy, in Brittany, in Anjou, and in the eastern Pyrenees, as well as smaller deposits in 20 other departments. The most important of these deposits, historically, politically, and economically, are the minette ores of the Lorraine Basin, and because of their importance they will be described in much greater detail than the rest of the European deposits.

\section{LORRAINE BASIN. ${ }^{49}$}

HISTORY.

As the ores of Lorraine contain much phosphorus they were used only to a small extent prior to 1878 , when a new metallurgic process gave them larger value. Nevertheless, after the Franco-Prussian

48 Conway, Martin, The political status of Spitzbergen: Geog. Jour. (London), vol. 53, No. 2, p. 83.

${ }^{19}$ Ansel, H., Die oolitische Eisenerzformation deutsches Lothringen: Zeitschr. prakt. Geologie, pp. 81-94, 1901. Bailly, L., Exploitation du minerai de fer oolithique dela Lorraine: Annales des mines, 10th ser., vol.7, pp. 5-55, 1905. Cayeux, L., Le minerai de Lorraine, Paris, 1918. Kohlmann, W., Die neuere Entwicklung deslothringischen Eisenerzbergbaues: Stahl und Eisen, vol. 31, pt.1, pp. 413-424, 469-479, 544-556, 1911. Kohlmann, W., Die Minnettcablagerung des lothringischen Jura: Stahl und Eisen, vol. 22, pt. 1, p. 493, 1902. Krecke, F., Eisenerz und Kohle in Französisch-Lothringen: Glückauf, vol. 46, pt. 1, pp. 4-9, 1910. Lynch, M. C., Why France needs the Briey Basin: Iron Trade Rev., vol. 60, p. 924, 1917. Villain, M., Le gisement de minerai de fer oolithique de la Lorraine: Annales des mines, 10th ser., vol. 1, pp. 113-322, 1902. Nicou, P., Les ressources de la France en minerais de fer: The iron ore resources of the world (11th Internat. Ceol. Cong.), vol. 1, pp. 4-14, Stockholm, 1910. Einecke, G., and Köhler, W., Die Eisenvorräte des deutschen Reiches: Idem, vol. 2, pp. 711-715. 
war the Germans were very careful to take away from France all the ore bodies in Lorraine that appeared to have any value. In fact, the boundary set for Lorraine was decided upon by strategists after consultation with the metallurgist Stumm and the mining engineer Hauchecorne.

After 1878, when Thomas and Gilchrist discovered a method of converting high-phosphorus pig iron into steel, the value of the minette ores was greatly enhanced. French geologists urged prospecting for deeper ores east of the areas where mines were being worked and found that the greater and richer part of the ores of the Lorraine Basin actually remained to France.

Minette iron ore produced from 1871 to 1913.

[Metric tons.]

\begin{tabular}{|c|c|c|c|c|}
\hline Year. & $\begin{array}{l}\text { Lorraine } \\
\text { Annexée. }\end{array}$ & Luxemburg. & $\begin{array}{l}\text { French } \\
\text { Lorraine. }\end{array}$ & $\begin{array}{c}\text { Total } \\
\text { minette ore. }\end{array}$ \\
\hline 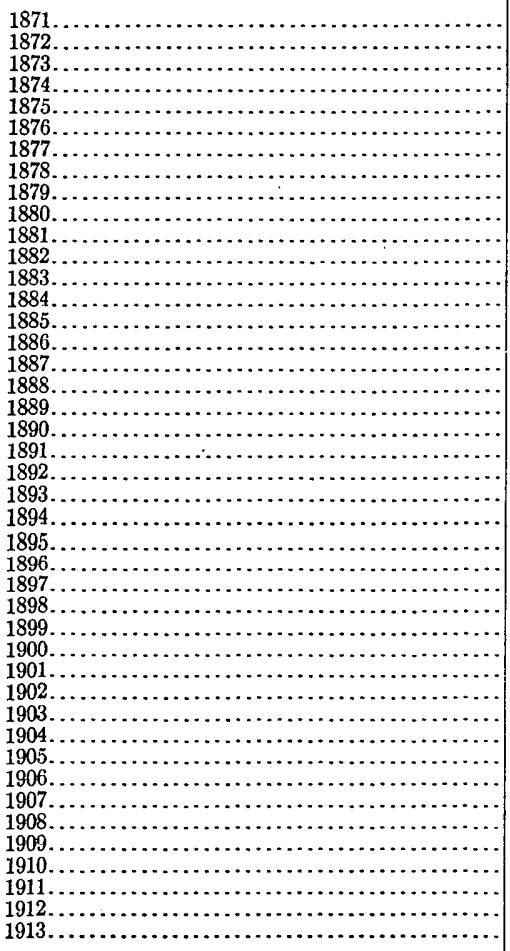 & $\begin{array}{r}364,000 \\
678,000 \\
860,000 \\
821,000 \\
744,000 \\
661,000 \\
678,000 \\
822,000 \\
830,000 \\
996,000 \\
1,096,000 \\
1,359,000 \\
1,644,000 \\
1,909,000 \\
2,153,000 \\
2,102,000 \\
2,471,000 \\
2,805,000 \\
2,959,000 \\
3,256,000 \\
3,126,000 \\
3,571,000 \\
3,607,000 \\
3,922,000 \\
4,222,000 \\
4,842,000 \\
5,361,000 \\
5,955,000 \\
6,973,000 \\
7,742,000 \\
7,595,000 \\
8,793,000 \\
10,683,000 \\
11,135,000 \\
11,968,000 \\
13,834,000 \\
14,102,000 \\
13,282,000 \\
14,443,000 \\
16,652,000 \\
17,743,000 \\
20,083,000 \\
21,136,000\end{array}$ & $\begin{array}{r}990,000 \\
1,174,000 \\
1,332,000 \\
1,443,000 \\
1,091,000 \\
1,197,000 \\
1,263,000 \\
1,408,000 \\
1,613,000 \\
2,173,000 \\
2,162,000 \\
2,539,000 \\
2,551,000 \\
2,448,000 \\
2,648,000 \\
2,361,000 \\
2,650,000 \\
3,262,000 \\
3,103,000 \\
3,359,000 \\
3,102,000 \\
3,370,000 \\
3,352,000 \\
3,958,000 \\
3,913,000 \\
4,759,000 \\
5,349,000 \\
5,349,000 \\
6,014,000 \\
6,171,000 \\
4,455,000 \\
5,130,000 \\
6,010,000 \\
6,348,000 \\
6,596,000 \\
7,229,000 \\
7,493,000 \\
5,801,000 \\
5,794,000 \\
6,263,000 \\
6,060,000 \\
6,511,000 \\
7,333,000\end{array}$ & $\begin{array}{r}505,000 \\
1,009,000 \\
1,289,000 \\
920,000 \\
976,000 \\
1,060,000 \\
1,126,000 \\
1,287,000 \\
1,343,000 \\
1,658,000 \\
1,796,000 \\
2,160,000 \\
2,140,000 \\
1,980,000 \\
1,612,000 \\
1,714,000 \\
1,953,000 \\
2,261,000 \\
2,413,000 \\
2,630,000 \\
2,735,000 \\
2,928,000 \\
2,810,000 \\
3,062,000 \\
3,084,000 \\
3,441,000 \\
3,804,000 \\
3,884,000 \\
4,106,000 \\
4,446,000 \\
3,842,000 \\
4,129,000 \\
5,282,000 \\
5,954,000 \\
6,400,000 \\
7,399,000 \\
8,738,000 \\
8,446,000 \\
10,684,000 \\
13,137,000 \\
14,858,000 \\
17,235,000 \\
19,629,000 \\
\end{array}$ & $\begin{array}{r}1,860,000 \\
2,861,000 \\
3,480,000 \\
3,183,000 \\
2,810,000 \\
2,917,000 \\
3,067,000 \\
3,517,000 \\
3,787,000 \\
4,828,000 \\
5,054,000 \\
6,058,000 \\
6,336,000 \\
6,338,000 \\
6,412,000 \\
6,177,000 \\
7,074,000 \\
8,329,000 \\
8,475,000 \\
9,246,000 \\
8,963,000 \\
9,870,000 \\
9,769,000 \\
10,942,000 \\
11,219,000 \\
13,041,000 \\
14,514,000 \\
15,188,000 \\
17,093,000 \\
18,360,000 \\
15,892,000 \\
18,053,000 \\
21,975,000 \\
23,437,000 \\
24,963,000 \\
28,463,000 \\
30,333,000 \\
27,529,000 \\
30,921,000 \\
36,052,000 \\
38,661,000 \\
43,829,000 \\
48,098,000\end{array}$ \\
\hline
\end{tabular}

Figures for 1871-1910 are those given by W. Kohlmann in Die neuere Entwicklung des lothringischen Eisenerzbergbaues: Stahl und Eisen, vol.31, pt. 1, p. 547, 1911. Figures for 1911, 1912, and 1913 from official statistics.

The table shows that the output of French Lorraine had far surpassed that of Luxemburg and was rapidly reaching that of German Lorraine (Lorraine Annexée) before the war began, in 1914. The 
comparative rates of increase in mining in these three regions is clearly shown in the accompanying diagram (fig. 15), which indicates that the progress of mining iron ore has been steadier in German

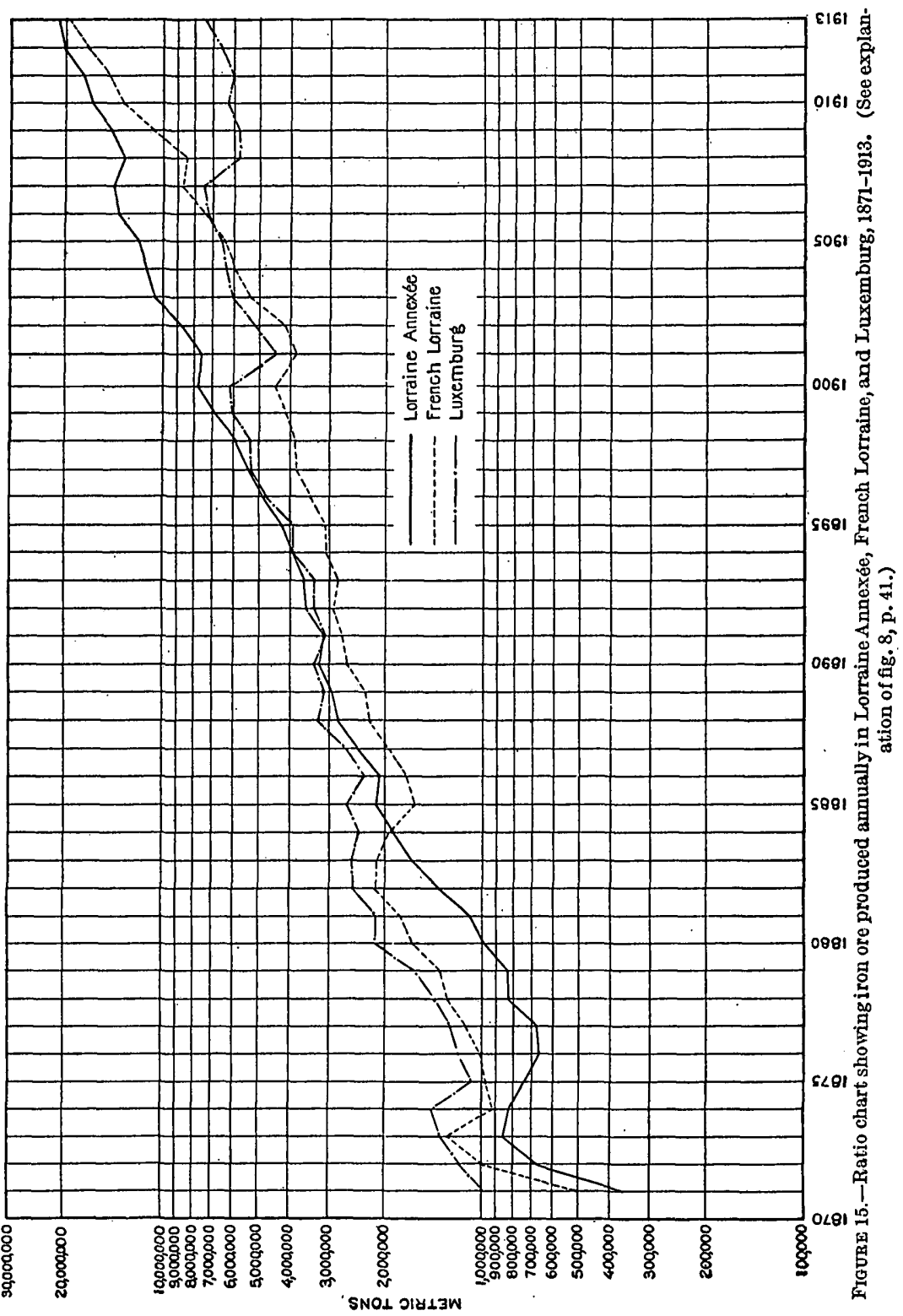

Lorraine than in either French Lorraine or Luxemburg. Indeed, Luxemburg appears to have lost more in recent bad years, such as 1900 and 1901 and 1907 and 1908, than either of the other regions. 


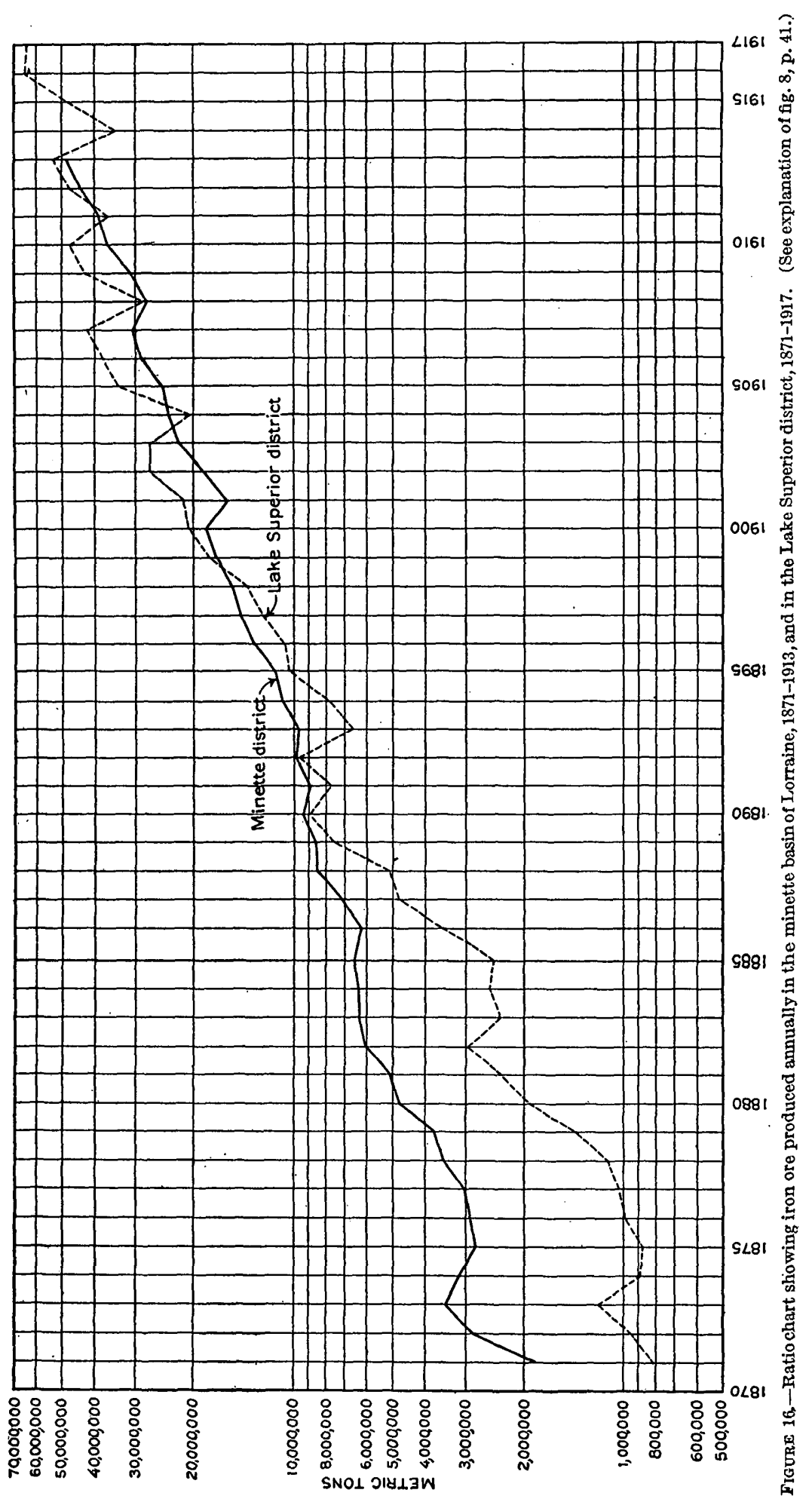


From 1908 to 1913 French Lorraine was rapidly gaining on German Lorraine, whereas Luxemburg, since her bad years 1907 and 1908, had only in 1913 regained her production of 1907.

In figure 16 the rate of increase of production in the Lorraine Basin is compared with that in the Lake Superior district. The curve for the Lorraine Basin is derived from the table given above. That for the Lake Superior district is derived from a table given by E. F. Burchard..$^{50}$ The figure shows that the average rate of increase in the Lake Superior district has been greater than that in the Lorraine Basin; also that the output of the Lake Superior district is subject to much wider fluctuations than that of the Lorraine Basin. The causes of these fluctuations are worthy of consideration by American economists.

In 1913 French Lorraine was producing much more ore than she needed for domestic consumption and was exporting the surplus to Belgium, Luxemburg, and Germany. The output of German Lorraine was handled almost entirely in furnaces within the German Customs Union. France had a surplus to export; Germany was an importer, and an increasingly heavy one, a fact that was undoubtedly recognized by the Germans before they started the war and that may even have increased their readiness to start it. It certainly affected their strategy, for their desperate assaults on the Verdun salient, which was a continual menace to their iron-mining regions, were probably due in part to their desire to safeguard their hold on those regions. Their plans and desires for the future are fully shown by the memoranda drawn up by the German Association of Metallurgists and Steel Makers and by P. Krusch's article in "Das neue Deutschland" of March 15, 1918. They all insist on the overwhelming value of the minette ore in the prosecution of the war and on the need of so "rectifying the frontier" as to include the Briey district, because of its importance for the "next" war.

How the French regard the iron ores of Lorraine is well shown in a recent paper by $\mathrm{L}$. Cayeux, ${ }^{51}$ whose temperamental aversion to accepting the really excellent estimates of the earlier German writers ${ }^{52}$ and whose shrewd, practical conclusion that it will be best for France to export some Lorraine ore to Germany ${ }^{53}$ reveal the typical French psychology. ${ }^{54}$

\footnotetext{
${ }^{30}$ Burchard, E. F., Iron ore, pig iron, and steel: U. S. Geol. Survey Mineral Resources 1917, pt. 1, p. 572, 1919.

sl Cajeux, L., Le minerai de Lorraine, Paris, 1918.

52 Idem, p. 25.

6s Idem, p. 36.

of The iron and related industries of the Lorraine Basin are considered in detail by Brooks and La Croix in Bulletin 703 of the U. S. Geological Survey.
} 


\section{EXTENT AND CHARACTER OF THE DEPOSITS.}

The minette ore fields lie in eastern France, in the Departments of Meurthe-et-Moselle and Lorraine, and extend into Luxemburg and

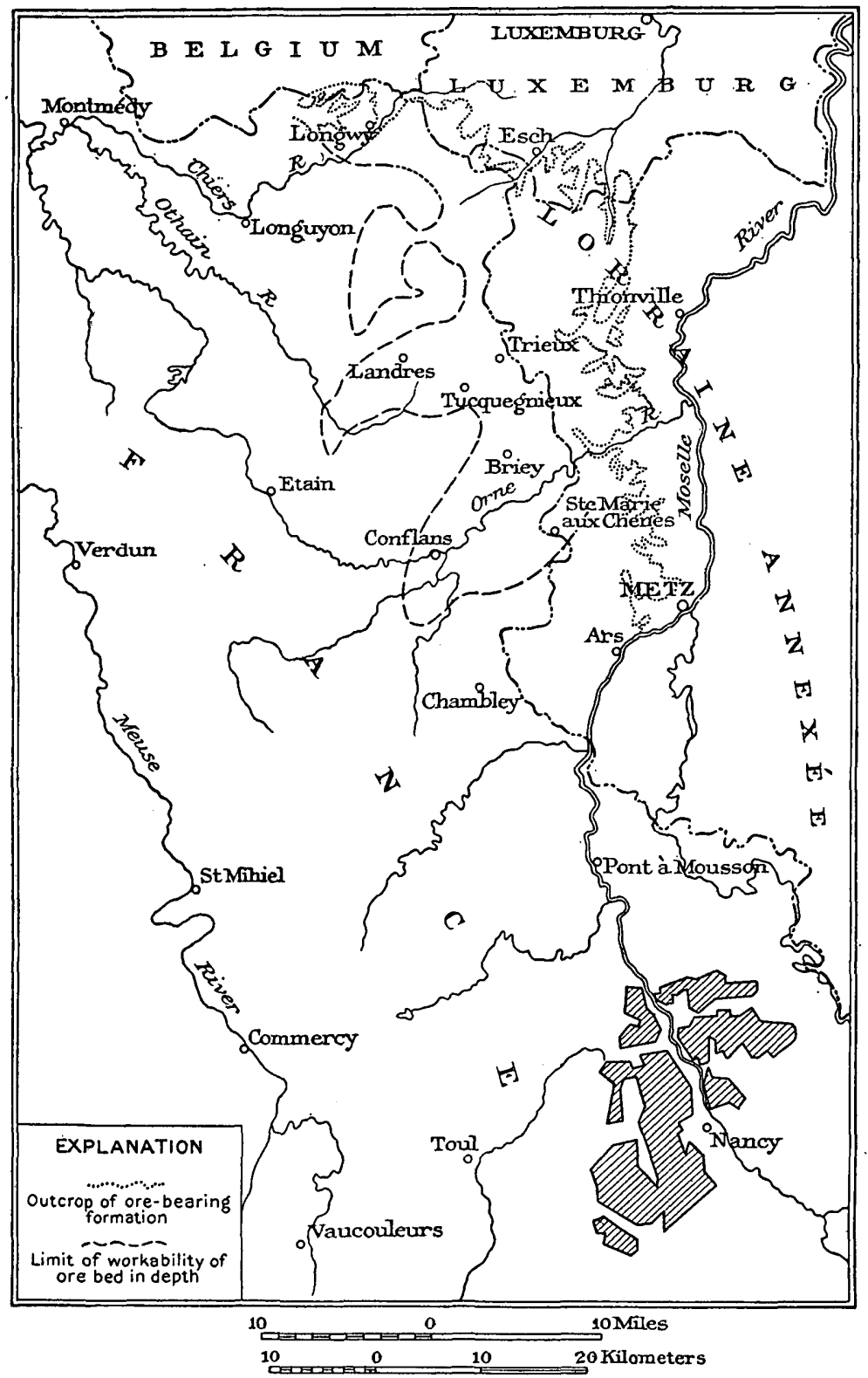

Figure 17.-Sketch map of the minette iron-ore basin, showing the position of the deposits, the FrancoGerman boundary of 1870 , and iron-mining concessions in the vicinity of Nancy.

the Belgian province of Luxemburg. (See fig. 17.) The main deposit extends southward from Belgium to a point 5 miles below Orne River, where the ores become too lean to be worth mining. The iron forma- 
tion continues to the south and near Nancy is again workable. The sinuous line indicating the western limit of ore on the sketch map is not the limit of the ore formation but represents the extent of the ore that is regarded as workable under present conditions. It may be extended considerably in the future. The eastern limit is the outcrop of the ore-bearing formation.

Of the recognized deposits an area of 3,600 hectares lies in Luxemburg and an area of 71,600 hectares in France. The Belgian part of the basin has been exhausted.

The deposits are sedimentary, lie in synclinal basins that pitch to the southwest, and are cut into blocks by faults that extend from northeast to southwest and from northwest to southeast. Most of the faults are of slight displacement and do not greatly affect the deposits, but the Crusnes fault has a throw of as much as 120 meters. These minor structural basins are themselves a part of the great Paris Basin, of which they form the eastern rim.

Mineralogically the ores are mainly oolitic brown ores, cemented by lime, clay, or sandy clay, but some siderite is present. The grains of oolite average about 0.25 millimeter in diameter and are composed predominantly of ferric hydrate but contain some hematite, iron silicate, and iron carbonate.

That they are sedimentary deposits seems to be fairly well established, though some geologists believe that they were formed by metasomatic replacement of calcareous oolites.

The ore is classed as calcareous or siliceous, according to the cement. The following analyses ${ }^{55}$ show the range in composition of the two types:

Chemical composition of minette ores.

\begin{tabular}{|c|c|c|}
\hline & Calcareous. & Siliceous. \\
\hline 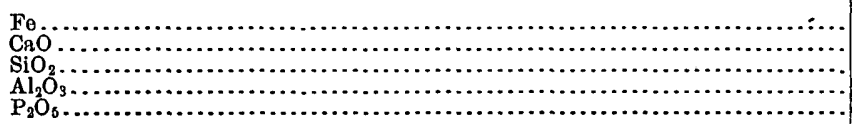 & $\begin{array}{r}26 \text { to } 40 \\
8 \text { to } 20 \\
4 \text { to } 8 \\
2 \text { to } 6 \\
1.5 \text { to } 2\end{array}$ & $\begin{array}{r}30 \text { to } 40 \\
4 \text { to } 10 \\
8 \text { to } 15 \\
2 \text { to } 8 \\
1.5 \text { to } 2\end{array}$ \\
\hline
\end{tabular}

The ore occurs as bedded masses that are almost entirely free from inclusions of barren material. The deposits are interbedded with clays, limestones, and sandstones of Jurassic age. The French place them at the top of the series, below the Lower Dogger, but the Germans regard them as the bottom member of the Lower Dogger.

The seven recognized ore beds vary considerably in thickness and in composition. At some places the beds include masses of ferruginous limestone, which are sorted out and used as a flux with siliceous

${ }_{65}$ Kohlmann, W., Die neuere Entwicklung des lothringischen Eisenerzbergbaues: Stahl und Eisen, vol. 31 , pt. 1, p. 415, 1911. 
ores. Between the ore beds lie beds of limestone, marl, and sandy marl. The following is a generalized section:

Hanging wall:

Section of minette ore beds.

Dense, impervious marl.

Red siliceous ore.

Middle calcareous ore series:

Red calcareous ore.

Yellow ore.

Gray ore.

Lower siliceous ore series:

Brown ore.

Black ore.

Green ore.

Footwall of sandy marl.

This section is at few places seen in its entirety, and even where a large part of it is present the mining is commonly limited to one of the beds because the others are not of exploitable thickness.

The following analyses ${ }^{56}$ shows the arerage composition of the more valuable beds:

Chemical composition of minette beds.

\begin{tabular}{|c|c|c|c|c|c|c|c|}
\hline & Fe. & $\mathrm{CaO}$. & MgO. & P. & $\mathrm{SiO}_{2}$ & $\mathrm{Al}_{2} \mathrm{O}_{3}$ & $\begin{array}{l}\mathrm{CO}_{2} \\
\mathrm{H}_{2} \mathrm{O}\end{array}$ \\
\hline 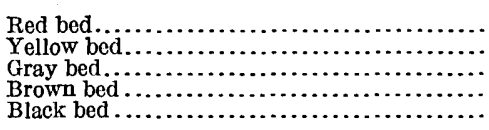 & $\begin{array}{l}40.4 \\
38.0 \\
31.8 \\
24.0 \\
39.7\end{array}$ & $\begin{array}{r}8.2 \\
9.8 \\
19.0 \\
8.6 \\
5.9\end{array}$ & $\begin{array}{r}0.5 \\
1.5 \\
.5 \\
2.0 \\
.5\end{array}$ & $\begin{array}{r}0.7 \\
.3 \\
.7 \\
.6 \\
.7\end{array}$ & $\begin{array}{r}9.6 \\
7.0 \\
7.0 \\
16.6 \\
15.1\end{array}$ & $\begin{array}{l}5.5 \\
4.2 \\
2.3 \\
6.5 \\
5.2\end{array}$ & $\begin{array}{l}14 \\
\dddot{22} \\
\dddot{14}\end{array}$ \\
\hline
\end{tabular}

The most valuable of these is the gray bed, which covers almost the entire district and reaches a maximum thickness of 7 meters.

The ore is mined by open cuts, adits, and shafts, the means chosen depending, in general, upon the depth of the ore below the surface of the ground. As most of the outcrops are in the eastern part of the area, formerly German, Germany had the advantage of working the more easily mined material. Lower costs of labor and a slightly higher average grade of ore made it possible for French ore to compete with German in spite of more costly methods of mining.

The minette ores owe their value to their proximity to the coal of Westphalia, the Saar, and Belgium; to the fact that they afford self-fluxing mixtures, and to the commercial value of the phosphatio slag formed in converting Lorraine pig iron to steel. The iron content of the ore smelted has been decreasing gradually, though this is not to be taken as indicating that the more recently developed and deeper-lying ore masses are of inferior grade, but rather

${ }^{66}$ Einecke, C., and Köhler, W., Die Eisenerzvorräte des deutschen Reiches: The iron-ore resources of the world (11th Internat. Geol. Cong.), vol. 2, p. 714. 
that now the fractions of the developed masses that are mined out are larger than formerly.

\section{RESERVES.}

The reserves of ore in the Lorraine Basin were very carefully estimated in 1911, as well as before and since that time. The estimates used here are taken from Kohlmann. ${ }^{57}$ The estimate he gives for the French part of the basin is a modification of that given by Villain. ${ }^{58}$

Iron ores in the Lorraine Basin in 1911.

[Millions of metric tons.]

\begin{tabular}{|c|c|c|c|}
\hline & $\begin{array}{l}\text { Calcareous } \\
\text { ore. }\end{array}$ & $\begin{array}{l}\text { Silliceous } \\
\text { ore. }\end{array}$ & Total. \\
\hline 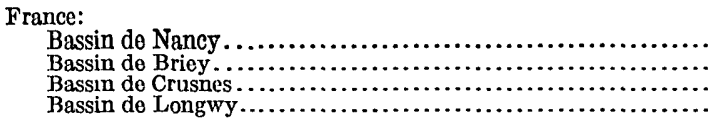 & 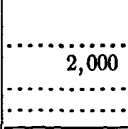 & $\begin{array}{r}200 \\
600 \\
300\end{array}$ & $\begin{array}{r}200 \\
2,000 \\
600 \\
300 \\
\end{array}$ \\
\hline Total in France. . & 2,000 & 1,100 & 3,300 \\
\hline 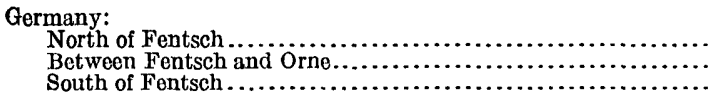 & $\begin{array}{l}863 \\
385 \\
180\end{array}$ & $\begin{array}{c}263 \\
150\end{array}$ & $\begin{array}{r}1,126 \\
385 \\
330\end{array}$ \\
\hline 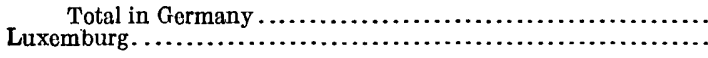 & $\begin{array}{r}1,428 \\
125\end{array}$ & $\begin{array}{l}413 \\
125\end{array}$ & $\begin{array}{r}1,841 \\
250\end{array}$ \\
\hline Total in Lorraine Basin. & 3,553 & 1,638 & 5,191 \\
\hline
\end{tabular}

The above estimates show evidence of careful consideration and conservative calculation. Only ore that met the metallurgic requirements of that time and that could profitably be extracted with the mining methods then in use was taken into consideration. Since that time there have been improvements in the methods of handling the ore and advances in metallurgic practice. The French estimates can also be increased, because the ore may, perhaps, be followed west of the area in which concessions have been granted.

After considering all the factors enumerated and studying all information available the estimates given on page 64 were adopted.

s7 Kohlmann, W., Dio neuere Entwicklung des lothringischen Eisenerzbergbaues: Stahl und Eisen, vol. 31, pt. 1, pl. 419, 1911.

68 Villain, M., Lo gisement de minerai de fer oolithique de la Lorraine: Annales des mines, 10th ser., vol. 1, pp. 113-322, 1902. 
Iron resources of the Lorraine Basin.

[Millions of metric tons.]

\begin{tabular}{|c|c|c|c|c|c|c|}
\hline & \multicolumn{2}{|c|}{ Known. } & \multicolumn{2}{|c|}{ Probable. } & \multicolumn{2}{|c|}{ Possible. } \\
\hline & Ore. & Iron. & Ore. & Iron. & Ore. & Iron. \\
\hline \multirow[t]{3}{*}{ 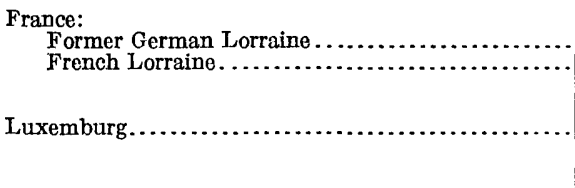 } & $\begin{array}{l}1,800 \\
3,000\end{array}$ & $\begin{array}{l}558 \\
990\end{array}$ & $\begin{array}{l}500 \\
750\end{array}$ & $\begin{array}{l}150 \\
225\end{array}$ & $\begin{array}{r}500 \\
1,000\end{array}$ & $\begin{array}{l}150 \\
300\end{array}$ \\
\hline & $\begin{array}{r}4,800 \\
200\end{array}$ & $\begin{array}{r}1,548 \\
60\end{array}$ & $\begin{array}{r}1,250 \\
70\end{array}$ & $\begin{array}{r}375 \\
21\end{array}$ & 1,500 & 450 \\
\hline & 5,000 & 1,608 & 1,325 & 396 & 1,500 & 450 \\
\hline
\end{tabular}

NORMANDY..$^{59}$

In northern France, in the old Province of Normandy, in the Departments of Orne, Calvados, and Manche (see Pl. VII), lie the ore deposits which rank second in importance to France. The history of iron making in Normandy is like that in other countries that have long been inhabited. Steel from ore mined in Normandy helped William the Conqueror to win the battle of Hastings. But gradually the forests used in making charcoal for smelting the ore approached exhaustion and laws were passed to conserve the remaining forests, so that the iron industry died and Norman ores were forgotten for many years. Then came the modern need of iron and the use of coal. But Normandy lacks coal, so the future value of its iron ores lies in their ability to compete with other ores in foreign markets. That they can so compete is shown by the fact that before the war the Germans had become heavily interested in the ore deposits of the district.

According to Cayeux the ores are all oolitic. The original oolite, which was composed of calcium carbonate, was replaced by siderite, and siderite is still the primary mineral, but where it lies near the surface it has been altered to oxides, and near Dielette ${ }^{60}$ it has been metamorphosed to form beds of hematite and magnetite.

The deposits, though of secondary origin, are intercalated in sedimentary beds, and their distribution is due to complex folds that have an east-west trend. Plate VII shows the location of

59 Bigot, A., L'exploitation des mines de fer de la Basse-Normandie: Rev. gén. sci. pures et appl., vol. 24, pp. 346-352, 1913. Bigot, A., Le bassin minière de la Basse-Normandie: Idem, pp. 258-263. Cayeux, L., Structure et origine probable du minerai de fer magnétique de Dielette: Compt. Rend., vol. 142, pp. 716-718, 1906. Cayeux, L., Coup d'œil sur les minerais de fer de la presqu'ile armoricaine: Soc. française de minéralogie Bull., vol.41, p. 134, Nos. 7, 8, July-December, 1918. Cayeux, L., Les minerais de fer oolithiques de France, Paris, 1909. Heurteau, C. E., Note sur le minerai de fer silurien de Basso-Normandie: Annales des mines, 10th ser., vol.11, pp.613-668, 19.07. Maulde, J. de, Les mines de fer et l'industrie métallurgique dans le Département du Calvados, Caen, 1916. Nicou, P., Les ressources de la France en minerais de fer: The iron-ore resources of the world (11th Internat. Geol. Cong.), vol. 1, pp. 15-20, Stockholm, 1910.

${ }^{\infty}$ Cayeux, L., Structure et origine probable du minerai de fer magnétique de Dielette: Compt. Rend., vol. 142, pp. 716-718, 1906 . 


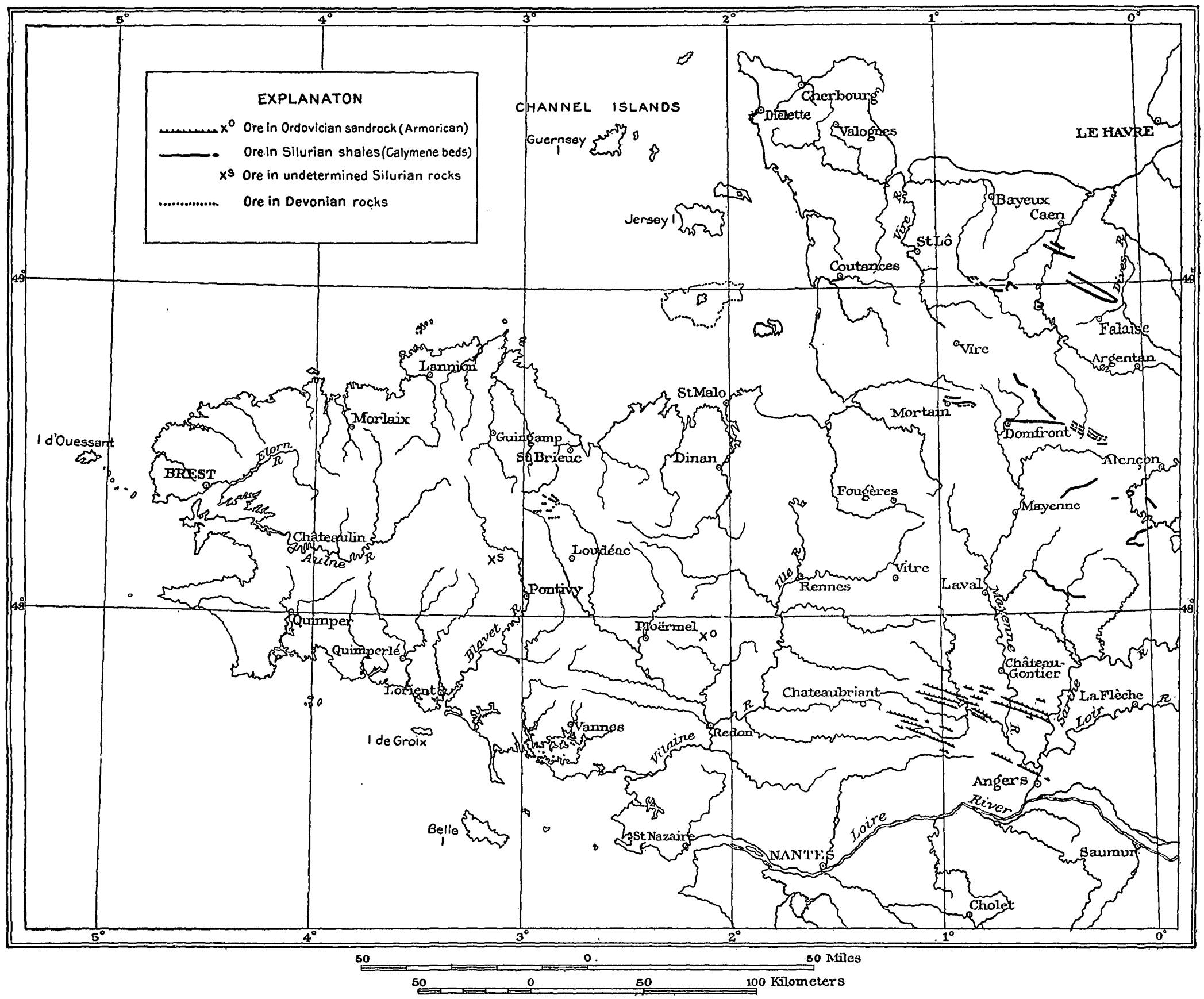

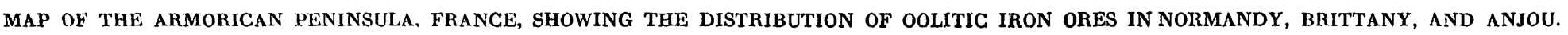


some of the deposits. The outcrops occur from Caen on the north to Domfront on the south and from Falaise on the east to the coast at Dielette on the west. The ore beds occur in stratified formations of Ordovician age, except at Dielette, where the age of the rocks is Darwin, and these formations belong to the folded early Paleozoic and ancient group of rocks that constitute the old land mass known as the Armorican Peninsula. This peninsula of northwestern France, the massif of south-central France, the western part of the Iberian Peninsula, and the Scandinavian massif are the four land masses in Europe that have stood above the level of marine invasions since early Paleozoic time.

According to $\mathrm{P}$. Nicou ${ }^{\text {a1 }}$ the reserve of the entire Armorican Peninsula amounts to about $220,000,000$ tons. Their estimates amount to 4,700,000,000 tons. An estimate by L. Cayeux ${ }^{\mathbf{6 2}}$ increases the estimate of available ore in the peninsula to $1,825,000,000$ tons. During years immediately preceding the war the Germans became much interested in these deposits, and German geologists made some studies of them that were published during the war. ${ }^{63}$

The average analysis of the ores of Normandy shows that they contain 47 per cent of iron, 12 per cent of silica, 3 per cent of alumina, and 0.6 to 0.7 per cent of phosphorus.

As the ores of Dielette are superior in grade to the ores of the rest of Normandy they were considered separately. They contain on an average 57 per cent of iron, 12 per cent of silica, and 0.25 per cent of phosphorus.

Iron resources of Normandy.

[Millions of metric tons.]

\begin{tabular}{|c|c|c|c|c|c|c|}
\hline . & \multicolumn{2}{|c|}{ Known. } & \multicolumn{2}{|c|}{ Probable. } & \multicolumn{2}{|c|}{ Possible. } \\
\hline & Ore. & Iron. & Ore. & Iron. & Ore. & Iron. \\
\hline $\begin{array}{l}\text { Dielette } \\
\text { Rest of Normandy } \ldots \ldots \ldots \ldots \ldots \ldots \ldots \ldots \ldots\end{array}$ & $\begin{array}{r}50 \\
175\end{array}$ & $\begin{array}{l}28 \\
77\end{array}$ & $\begin{array}{r}50 \\
1,000\end{array}$ & $\begin{array}{r}25 \\
400\end{array}$ & 2,000 & $\begin{array}{r}25 \\
800\end{array}$ \\
\hline
\end{tabular}

In this table the estimates made by Germans are purposely discounted, possibly without doing justioe to Krusch and Beyschlag, because it seemed to be to their advantage to overestimate rather than to underestimate.

ot Op. cit., p. 27.

or Cayeux, L., Coup d'œil sur les minerais de fer de la presqu'ile armoricaine: Soc. franç. minéralogio Bull., vol. 41, p. 134, 1918.

${ }^{63}$ Krusch, P., Das neue Deutschland, Mar. 15, 1918. 15945 ${ }^{\circ}-21-$ Bull. 706 -5 


\section{BRITTANY AND ANJOU. ${ }^{64}$}

Ore deposits similar to those of Normandy are found in somewhat younger rocks in Brittany and Anjou. This country forms the southern part of the Armorican Peninsula, and its geologic history is similar to that of Normandy. The location of this deposit is shown in Plate VII (in pocket).

The ores occur with sedimentary rocks of Silurian age, in part as intercalations and in part as surface deposits. They extend through the Departments of Maine-et-Loire, Loire-Inférieure, Morbihan, Vendée, Ille-et-Vilaine, and Mayenne. They are mostly brown ores and siderite, but locally ores of better than average grade contain hematite or magnetite.

The ores of Brittany and Anjou contain about 50 per cent of iron, 16 per cent of silica, 3 per cent of alumina, and from 0.3 to 0.75 per cent of phosphorus. Their composition varies greatly from place to place, and some of the ore contains sulphur.

An estimate made by Bellanger, ${ }^{65}$ though it is admittedly incomplete, was used as a basis for that given below.

Iron resources of Brittany and Anjou, France.

[Millions of metric tons.]

\begin{tabular}{|c|c|c|c|}
\hline & . & Ore. & Iran. \\
\hline $\begin{array}{l}\text { Known.... } \\
\text { Probable... } \\
\text { Possible... }\end{array}$ & & $\begin{array}{l}250 \\
500 \\
500\end{array}$ & $\begin{array}{l}115 \\
230 \\
230\end{array}$ \\
\hline
\end{tabular}

PYRÉNÉES-ORIENTALES. ${ }^{68}$

In the eastern Pyrenees, Province of Pyrénées-Crientales, near Canigou, as shown in figure 18, lie the ore deposits from which come most of the low-phosphorus iron ore produced in France. The deposits consist of lenses and veins of spathic ore or derived oxidation products in Silurian sediments. De Launay's description ${ }^{67}$ shows that the ore was deposited from solutions that were probably of hydrothermal origin. There is evidence of considerable replacement.

As marketed the ore contains about 54 per cent of iron, 3 to 4 per cent of manganese, 4 per cent of silica, and very little phosphorus.

\footnotetext{
64 Bellanger, E., Note sur l'importance probable du gisement ferrifère de l'Anjou: Annales des mines, 10th ser., vol. 20, pp. 452-456, 1911; Les minerais de fer de l'Anjou: La Nature, 1911. Cayeux, L., Coup d'œil sur les minerais de fer de la presqu'île armoricaine: Soc. franç. minéralogie Bull., vol. 41, p. 134, 1918. Nicou, P., Les ressources de la France en minerais de fer: The iron-ore resources of the world (11th Internat. Geol. Cong.), vol. 1, pp. 20-22, Stockholm, 1910.

65 Op. cit., p. 456 .

${ }^{66}$ Nicou, P., Les ressources de la France en minerais de fer: The iron-ore resources of the world (11th Internat. Geol. Cong.), vol. 1, pp. 22-27, Stockholm, 1910.

${ }^{67}$ Launay, L. de, Traité de métallogénie, gîtes minéraux et métallifères, vol. 2, pp. 386-392, Paris and Liége, 1913.
} 
The following estimate of the reserves is based on Nicou's estimate: Iron resources of Pyrénées-Orientales, France.

[Millions of metric tons.]

\begin{tabular}{|c|c|c|}
\hline & Ore. & Iron. \\
\hline 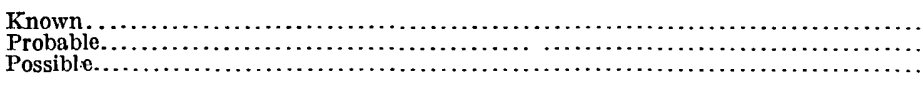 & $\begin{array}{l}30 \\
30 \\
30\end{array}$ & $\begin{array}{l}16.5 \\
16.5 \\
16.5\end{array}$ \\
\hline
\end{tabular}

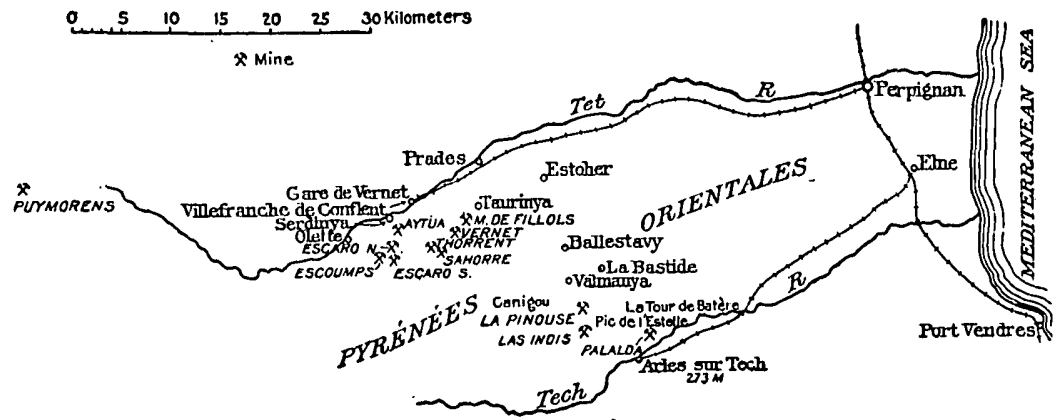

Figure 18.-Sketch map showing distribution of iron mines in the Province of Pyrénées-Orientales, France. (From "The iron-ore resources of the wordd.")

\section{HAUTE-MARNE. ${ }^{68}$}

The brown ores of the Department of Haute-Marne are intercalated at six horizons in lower Jurassic sediments. Some of this ore fills cavities, some is geoidal, and the top bed is oolitic. The mediumphosphorus ore now mined is taken from the oolitic bed. The analyses show approximate averages of 43 per cent of iron, 14 per cent of silica, 7 per cent of alumina, 2.5 per cent of manganese, and 0.4 per cent of phosphorus.

Figures given by Nicou indicate the resources tabulated below.

Iron resources of Haute-Marne.

[Millions of metric tons.]

\begin{tabular}{|c|c|c|}
\hline & Ore. & Iron. \\
\hline 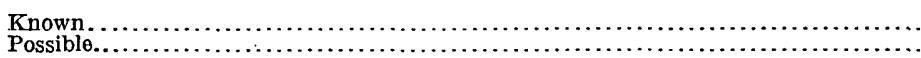 & $\begin{array}{l}13.5 \\
10.0\end{array}$ & $\begin{array}{l}5.5 \\
4.5\end{array}$ \\
\hline
\end{tabular}

In this estimate the bed now being mined is included in the "known" and the other beds in the "possible" reserve.

${ }_{68}$ Rigaud, F., Notice sur les minières de la Haute-Marne: Annales des mines, 7 th ser., vol. 14, pp. 9-62, 1878. Nicou, P., Les ressources de la France on minerais de fer: The Iron-ore resources of the world (11th Internat. Geol. Cong.), vol. 1, pp. 29-30, Stockholm, 1910. 
OTHER DEPOSITS.

According to official statistics 19 departments other than those mentioned furnished 335,000 metric tons of iron ore in 1913, and deposits are recorded in still other departments.

In Ariège and Basses-Pyrénées deposits similar to those of Pyrénées-Orientales produced about 61,000 tons of ore in 1913 . No definite estimate can be made of the quantity of ore left. These deposits can be credited with a reserve of probably 250,000 tons of metallic iron. The gossan deposits in the Department of Aude do not appear to be worth considering.

The Bordeaux Basin furnished 26,000 tons of ore from Lot, Lot-etGaronne, and Dordogne, and deposits are known in Charente and Haute-Garonne. The deposits in these Departments are brown ores, most of them carrying little phosphorus. They are of residual type and are probably not very extensive. They can be credited with probably 100,000 tons of iron.

Some deposits of iron ore are scattered along the edges of the massif in south-central France. Sedimentary deposits in the Department of Aveyron, at the southwest end of the massif, have produced 50,500 tons of high-phosphorus ore; other like deposits in Saône-etLoire, at the northeast end, produced 32,000 tons of high-phosphorus ore, and similar ore is found at Alliers. It is probably safe to count on 2,500,000 tons of iron from these deposits. In Ardèche and Hérault, on the southern edge of the massif, 27,000 tons of medium phosphatic iron ore were mined in 1913 . The deposits are approaching exhaustion and probably all that is left is about 250,000 tons of iron. In Indre, Vienne, Lozère, Tarn, and Gard about 80,300 tons of low-phosphorus ores have been mined, and because of their metallurgic desirability these ores will probably be mined to exhaustion. Gard, Tarn, and Indre appear to have considerable reserves and can be counted on for 2,500,000 tons of iron. Altogether probably $5,250,000$ tons of metallic iron may be extracted from the southcentral massif.

In southeastern France, in the Alpine districts of the Department of Isère, there are some gossan ores which have produced about 10,000 tons of low-phosphorus ores. In the mountains in the Department of Var there are brown ores, high in iron and medium phosphatic, which have a future. Nicou credits these deposits with a reserve of $3,000,000$ tons, which can be considered equivalent to $1,500,000$ tons of metallic iron. They produced 10,300 tons of ore in 1913.

The Departments of Jura and Haute-Saône, in the Jura Mountains, have produced 7,500 tons of ore. The ore is low in phosphorus but is also very low in iron.

There is some iron ore in the Paris Basin, in Cher, Nord, and Pas de Calais, but it is not of any importance as a reserve. 
The Departments that are of minor rank as compared with Lorraine, Normandy, Brittany and Anjou, and Pyrénées-Orientales show a combined probable reserve of $7,100,000$ tons of iron.

SUMMARY OF RESERVES.

France's total reserve of iron is estimated in the following table:

Iron resources of France.

[Millions of metric tons of iron. Compare PI. VI, in pocket.]

\begin{tabular}{|c|c|c|c|}
\hline & Known. & Probable. & Possible. \\
\hline \multirow[t]{2}{*}{ 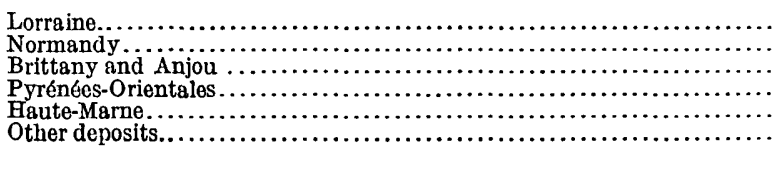 } & $\begin{array}{r}1,548.0 \\
105.0 \\
115.0 \\
16.5 \\
5.5 \\
\hdashline .1 .\end{array}$ & $\begin{array}{r}375.0 \\
425.0 \\
230.0 \\
16.5 \\
7.1\end{array}$ & $\begin{array}{r}450.0 \\
825.0 \\
230.0 \\
16.5 \\
4.5 \\
\end{array}$ \\
\hline & $1,790.0$ & $1,053.6$ & $1,526.0$ \\
\hline
\end{tabular}

\section{PRODUCTION AND CONSUMPTION.}

Figure 19 shows the rapidly accelerating growth of the production of iron ore in France prior to 1910. Details of the production in 1913, by Departments, from French official statistics, follow:

Iron ore produced in France in 1913, by Departments.

\begin{tabular}{|c|c|c|c|}
\hline Ardèche.. & $\begin{array}{r}\text { Metric tons. } \\
26,783\end{array}$ & Lot-et-Garonne.. & $\begin{array}{r}\text { Metric tons. } \\
33,479\end{array}$ \\
\hline Ariège & 36,569 & Lozère........... & 200 \\
\hline Aveyron..................... & 50,414 & Maine-et-Loire.. & 130,193 \\
\hline Basses-Pyrénées.............. & 23,507 & Manche............ & 61,388 \\
\hline Calvados................... & 388,923 & Mayenne.. & 3,000 \\
\hline Dordogne...... & 2,600 & Meurthe-et-Moselle. . & $19,978,937$ \\
\hline Gard........... & 31,998 & Orne.................. & 362,673 \\
\hline Haute-Marne . . . . . . . . . . & 57,714 & Pas de Calais.... & 15 \\
\hline Haute-Sâ̂ne............... & 1,500 & Pyrénées-Orientales.... & 333,778 \\
\hline Hérault. $\ldots \ldots \ldots \ldots \ldots, \ldots$ & 543 & Saône............... & 29,186 \\
\hline Ille-et-Vilaine . . . . . . . . . & 132,040 & Tarn............. & 11,253 \\
\hline Indre................... & 27,690 & Var................. & 10,31 \\
\hline Isère $\ldots \ldots, \ldots, \ldots, \ldots, \ldots$ & 9,968 & Vienne................... & 9,140 \\
\hline Jura & 5,946 & & \\
\hline 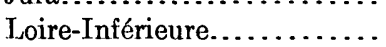 & 134,663 & & 0 \\
\hline Lot....................... & 23,352 & & \\
\hline
\end{tabular}

The production according to the major districts is shown below.

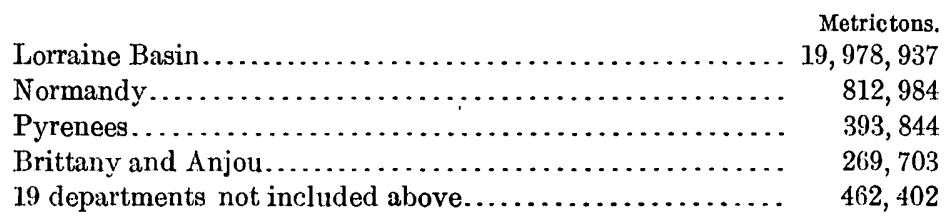


The production of iron ore in France in 1913 was 20.5 per cent and her consumption was 12 per cent of the European total. (See fig. 6, p. 28.)

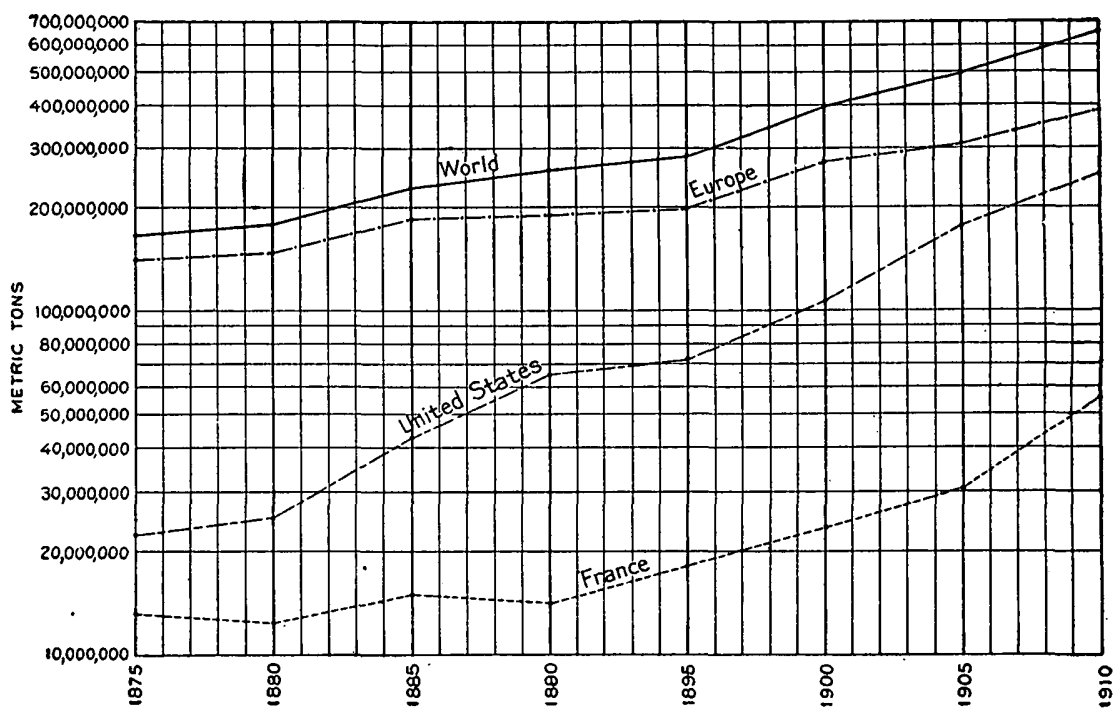

Figure 19.-Ratio chart showing iron ore produced during five-year periods ending 1875 to 1910 in France, Europe, the United States, and the world. (See explanation of fig. 8, p. 41.)

The progress of iron mining from 1894 to 1913 for France as a whole and for the Department of Meurthe-et-Moselle is shown in figure 20. Essentially all the product of Meurthe-et-Moselle has been minette ore from the Longwy, Briey, and Nancy basins. The future significance to France of controlling essentially all of the iron ore of

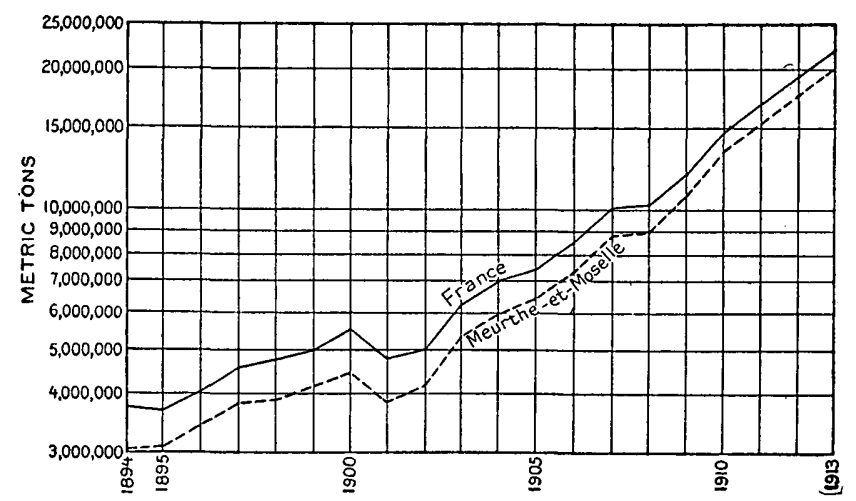

FIGURE 20.-Ratio chart showing iron ore produced annually in France and in the Department of Meurtheet-Moselle, 1894-1913. (See 3xplanation of fig. 8, p. 41.)

old Lorraine is indicated by the capacity of producing over $40,000,000$ tons of ore as demonstrated by the performance of 1913. What could France do with iron ore in such an amount as this? The extent 
to which the country has become an exporter of iron ore is shown in figures 5 (p. 27) and 21. Full control of the Saar Basin, the development of the Pont-à-Mousson field, the expansion of the production of Pas de Calais, and the increased use of friendly Belgian coal may take care of the greater part of the ore, but as none of this coal produces as good and as cheap coke as the coal of Westphalia, unless that coke is used the iron and steel produced will be proportionately more expensive than in the past-not a hopeful outlook for the ultimate consumer.

The shipment of ore to England and the return of coal has been suggested, ${ }^{09}$ but as this involves an added freight burden and a

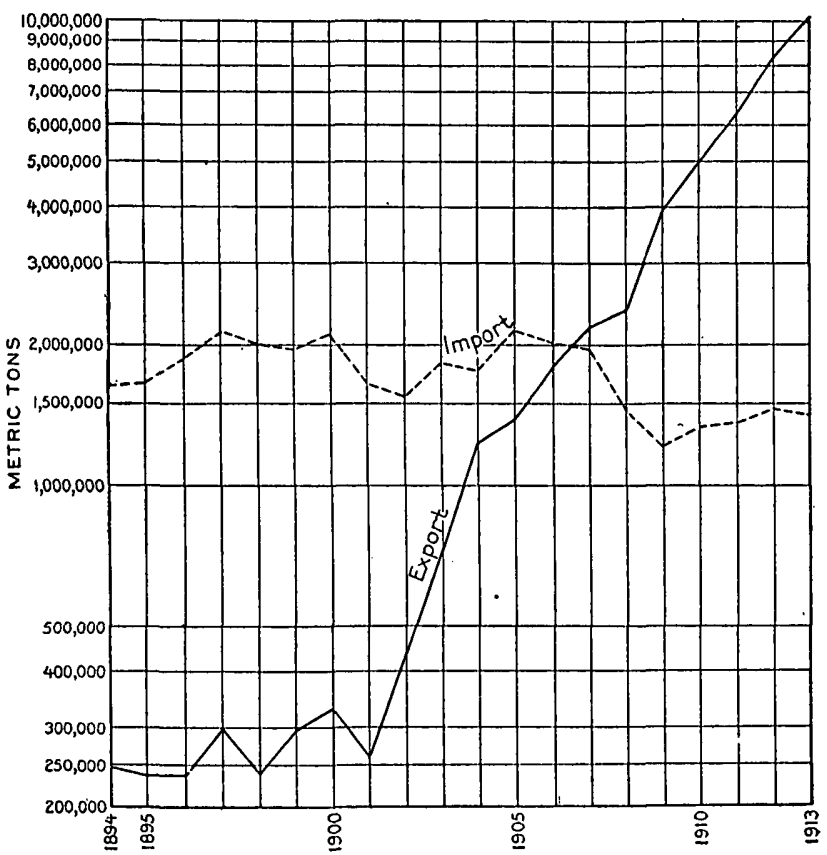

FIGURE 21.- Ratio chart showing iron ore exported and Imported annually by France, 1894-1913.

change in English smelting practice it does not appear to promise steel at a cost as low as could be attained by the use of Westphalian coal.

It may be possible for a time to compel the shipment of Westphalian coal to France without commensurate return of ore to Germany, assuming the rebuilding of destroyed steel plants and blast furnaces in France and Belgium and an expansion sufficient to take care of the iron ore formerly handled in Westphalia, but the enforced shipments without adequate exchange could last only during the term of Germany's punishment, and the assumption of the develop-

${ }^{60}$ Ferasson, L., La question du fer, Paris, Payot et Cie., 1918. 
ment of plants vastly beyond past performance may not be well founded. Assumptions of this sort are based on the development in France of a "flaire" for industrial expansion that seems contrary to the accepted genius of the French people. The logical though perhaps unpleasant course to follow is to resume as soon as possible an equitable interchange between Lorraine iron ore and Westphalian coal, and the fact that France realizes this is shown by a recent study made by Cayeux. ${ }^{70}$

The ore of Normandy was used to a greater extent during the war than ever before. If the French Government should follow a more liberal course in regard to mining concessions in this district it might be possible to build up a considerable export trade in ore with Great Britain, but the high-grade Brazilian ores probably offer a more economic source of supply for British furnaces. The low-phosphorus ores of the Pyrenees will continue to be sought in the future as in the past by makers of Bessemer steel.

The French iron industry seems assured of expansion in the near future, but it is not probable that France will develop a fuel-producing capacity comparable to her ore-producing capacity in spite of her. control of the Saar Basin. She should continue to be an exporter of iron ore. The policy of avoiding export by curtailing production would be somewhat in accord with French conservation tendencies, but in practice this policy would prevent France from taking the position in the iron-ore industry that her resources warrant.

\section{BELGTUM.}

\section{DISTRIBUTION, CHARACTER, AND EXTENT OF THE DEPOSITS.}

Although Belgium is able to attract much iron ore from abroad and ranked sixth in the list of producers of pig-iron in 1913, she ranked about twentieth among producers of iron ore in that year, with a production of approximately 150,000 tons.

The Belgium iron-ore deposits are of three types-bedded oolitic ores in Devonian rocks in Liége, Namur, and in Jurassic rocks in Luxemburg; vein deposits in Namur and Liége; and surficial brown ores in the Campine country of Antwerp and Limburg. The Belgian end of the Lorraine ore field is so nearly exhausted that it need not be considered.

Campine region.-Most of the iron ore produced in Belgium in recent years has been the high-phosphorus brown ores mined in the Campine region. The greater part of this ore was used for special purposes in Germany. The quantity still available has been estimated by Lespineux ${ }^{71}$ and the data given by him indicate that it 
contains "known" resources of metallic iron amounting to 2,500,000 metric tons and "probable" resources amounting to 2,500,000 metric tons.

Extensive deposits of iron ore are associated with the coal measures of the Campine field. They have been prospected by drilling, and Lambert ${ }^{72}$ discusses the possibility of utilizing them, but this possibility seems so remote that these ores have not been considered in calculating the reserves.

Namur-Liége district.-The bedded ores of Luxemburg have been practically exhausted, and those of the Namur-Liége district have been exhausted to a depth below which the underground water makes them so expensive to mine that they can not compete with the ores of the Lorraine Basin, which are imported from France. The vein deposits of the Namur-Liége district are not of much importance.

Several estimates of the amount of ore left in the Namur-Liége district have been made. A. Delmer ${ }^{73}$ estimated that some 351,000 ,000 metric tons of ore are still unmined. The geologist can accept this estimate, but the miner will probably never be able to work as far below water level as the geologist can estimate the iron content of a regular bedded deposit.

As very little of the ore can compete with other ores, because of the high cost of mining none of it is placed in the category of "known" ore as here defined. On the other hand it seems fair to take the $33,000,000$ metric tons which Delmer assumed to be workable as "probable" ore and to add double that amount for "possible" ore to allow for future developments in mining technology.

Iron resources of the Namur-Liége district.

[Millions of metric tons.]

\begin{tabular}{|c|c|c|}
\hline & Ore. & Iron. \\
\hline 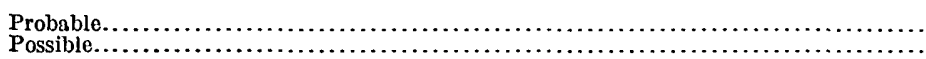 & $\begin{array}{l}33.0 \\
66.0\end{array}$ & $\begin{array}{l}11.6 \\
23.2\end{array}$ \\
\hline
\end{tabular}

The ore is an oolitic hematite in an argillaceous or calcareous cement. It averages 35 to 40 per cent of iron and contains only a medium amount of phosphorus.

72 Lambert, Guillaume, Découverte d'un puissant gisement de minerais de fer, etc., Brussels, 1904; critical review by B. Schulz-Briesen in Glückauf, vol. 41, pt. 1, pp. 37-42, 1905.

78 Delmer, A., La question du minerai de fer en Belgique: Annales des mines de Belgique, vol. 17, pp. 853-940; vol. 18, pp. 325-448, 1912-13. 
Iron resources of Belgium.

[Millions of metric tons of iron.]

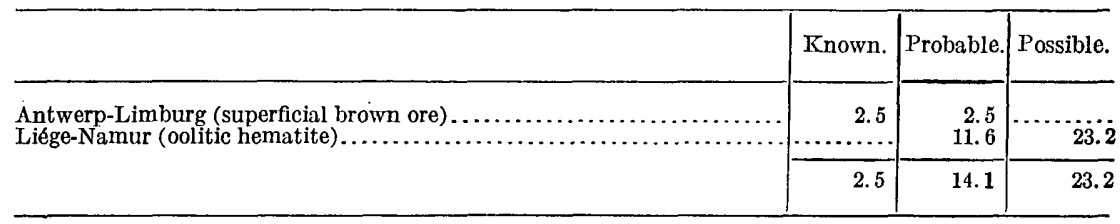

\section{PRODUCTION AND CONSUMPTION.}

As a producer of iron ore Belgium is nearly negligible. In 1913 she produced 150,000 tons of ore, and in the same year her blast furnaces consumed $7,100,000$ tons, equal to about 6.5 per cent of the total consumption in Europe. Of this ore over 6,500,000 tons came from the minette ore fields and the remainder from Spain and Sweden.

The iron industry of Belgium was originally based on the firm foundation of resources of domestic coal, but in recent years it has been cheaper to import from Germany much of the coal used rather than to depend entirely on domestic production. It will be to the advantage of Europe in general that Belgium should continue to draw on German coal, because it is the best and cheapest coal, but if political considerations should stop this normal trade, coal mining may be developed in Belgium to an extent sufficient to take care of her iron industry. The development of the Campine coal fields would have the additional advantage of making accessible the iron ores that are associated with the coal measures there.

\section{NETHERLANDS.}

The only iron ores in Holland are small superficial deposits of bog ore, which were once mined but are now entirely valueless. Holland has no iron industry but has some coal in the province of Limburg. It is reported that she is trying to start a factory to supply iron and steel for home consumption.

\section{IUXEMBURG.}

\section{DISTRIBUTION, CHARACTER, AND EXTENT OF THE DEPOSITS.}

The reserves of Luxemburg consist of a part of the ore of the Lorraine Basin described under the heading "France" (pp. 55-64). As only the edge of the basin lies in Luxemburg most of the ore is found near the surface and is mined open cast. As it is mined cheaply and can be used in self-fluxing mixtures, the ore is valuable in spite of its low grade. 
Iron resources of Luxemburg.

[Millions of metric tons.]

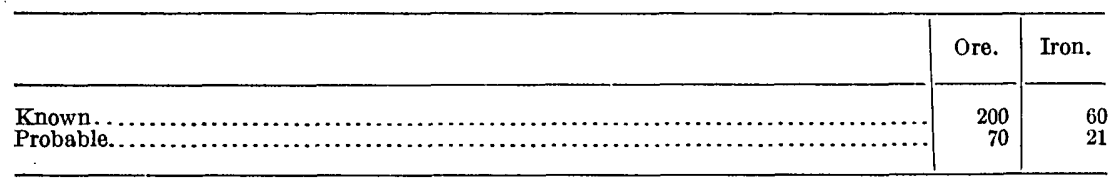

\section{PRODUCTION AND CONSUMPTION.}

The iron industry of Luxemburg has heretofore been bound up with that of the German Customs Union. Its gradual growth is shown by figure 15 (p.57). With her furnaces undamaged by war and aside from possible restrictions on imports of ore from France and of coal from Germany, there seems to be no reason why Luxemburg should not regain her former position as a producer of iron ore.

\section{GERMANY.}

\section{DISTRIBUTION, CHARACTER, AND EXTENT OF THE DEPOSITS.}

The inventory of the iron-ore deposits in Germany is probably more nearly adequate than that for any other country, the reports on which the estimates are based being both thorough and numerous. (See Pl. VIII, in pocket.) Those who made the estimates may differ in opinion as to the genesis of the ore-in fact, much of the German literature on the subject is devoted to more or less amicable disagreements-but the facts observed are so carefully recorded that the reader can safely draw his own conclusions.

The territorial rearrangements that affect the allocation of ore deposits are definitely outlined by the peace treaty. The uncertainties in regard to the boundary between West Prussia and Poland and the rearrangements that may be caused by a plebiscite in Silesia or the East Prussian districts can affect only amounts that are negligible in the sum total.

\section{SAAR VALLEY. ${ }^{74}$}

There is no large quantity of valuable iron ore in the district that has been taken from Germany to replace the destroyed coal fields of Pas de Calais. Some clay ironstone is associated with the coal, but it has no economic value, though it was used in the early days of the industry. ${ }^{75}$

\footnotetext{
71 Einecke, G., and Köhler, W., Die Eisenerzvorrïte des deutschen Reiches: K.-preuss. geol. Landes. anstalt Archiv für Lagerstättenforschungen, Feft 1, pp. 240-242, Berlin, 1910.

75 Hasslacher, A., Beitrïge zur ïlteren Geschichte des Eisenhüttenwesens im Saargebiete: Zeitschr. Berg-, Hütten- u. Salinenwesen preuss. St., vol. 44, pp. 75-97, 1896.
} 
WEST RHINE.

The territory west of the Rhine also contains little iron ore. Some brown ores are found in cavities in limestone near Aachen (Aix-la-Chapelle), and ore of the same sort in the Eifel district was the basis of an iron industry that can be traced back to ancient times. A little of this ore occurs also on the southern slope of the Soonwald. The production from the Aachener Kohlenkalkbezirk in 1913 was 3,722 tons.

Estimates made by Einecke and Köhler ${ }^{78}$ are tabulated below.

Iron resources of the region west of the Rhine.

[Millions of metric tons.]

\begin{tabular}{|c|c|c|c|c|c|c|}
\hline \multirow[t]{2}{*}{. } & \multicolumn{2}{|c|}{ Known. } & \multicolumn{2}{|c|}{ Probable. } & \multicolumn{2}{|c|}{ Possible. } \\
\hline & Ore. & Iron. & Ore. & Iron. & Ore. & Iron. \\
\hline \multirow{3}{*}{ 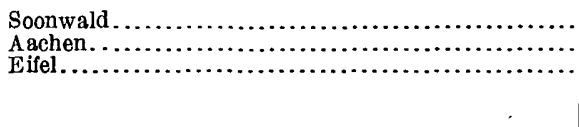 } & $\begin{array}{l}1.0 \\
3.0\end{array}$ & $\begin{array}{l}0.2 \\
1.1\end{array}$ & 0.30 & 0.1 & 0.5 & 0.2 \\
\hline & & & 5.00 & 1.9 & & \\
\hline & 4.0 & 1.3 & 5.30 & 2.0 & .5 & .2 \\
\hline
\end{tabular}

EAST RHINE.

The most valuable reserves remaining in German possession lie in the East Rhine region. The production in 1913 was 4,897,000 tons. The region is covered by the clause in the peace treaty forbidding fortifications. It will be taken up in detail by districts, from north to south.

Bergischer-Kalkberg district. ${ }^{77}$-The iron resources of the districts east of the Rhine consist of brown ores that were deposited in cavities in limestone. The Bergischer-Kalkberg district produced about $1,500,000$ metric tons of ore in the 50 years prior to 1913 , and its resources are not great. Einecke and Köhler's estimate shows that it can be credited with the reserve indicated below.

Iron resources of the Bergischer-Kalkberg district.

[Millions of metric tons.]

\begin{tabular}{|r|r|r|r|r|r|}
\hline \multicolumn{2}{|c|}{ Known. } & \multicolumn{2}{|c|}{ Probable. } & \multicolumn{2}{c|}{ Possible. } \\
\cline { 2 - 5 } Ore. & Iron. & Ore. & Iron. & Ore. & Iron. \\
\hline 3.5 & 1.4 & 5.5 & 2.2 & 4 & 1.6 \\
\hline
\end{tabular}

75 Op. cit., pp. 244-271.

"7 Einecke, G., and Köhler, W., op. cit., pp. 200-212. 


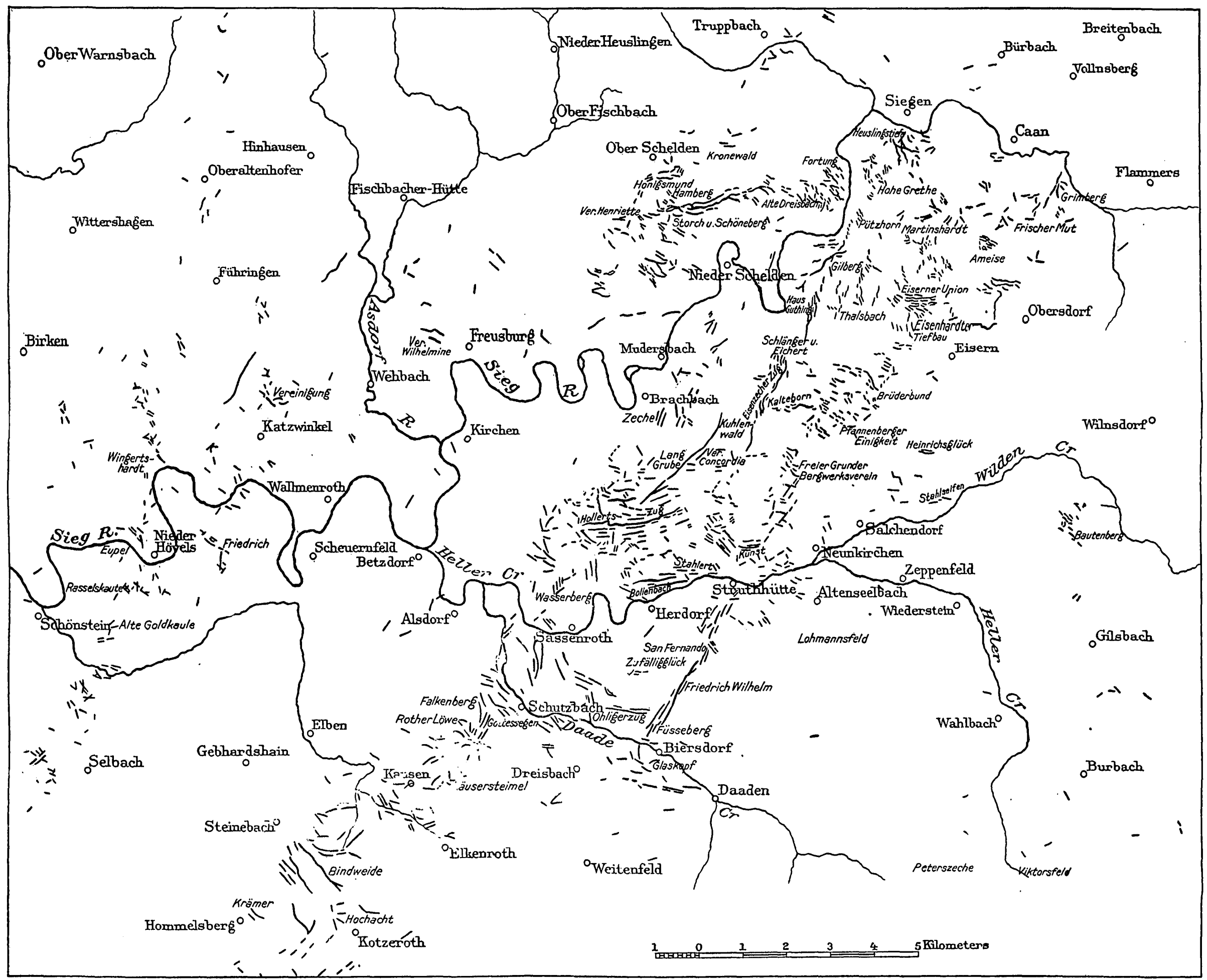

MAP SHOWING DISTRIBUTION OF THE SIDERITE DEPOSITS OF SIEGERLAND, GERMANY. 
Siegerland district. ${ }^{78}$-The ore of the Siegerland district is probably the most valuable in Germany. It is a very excellent grade of carbonate ore occurring in veins in Lower Devonian rocks. The distribution of the vein system is shown in Plate IX. The ore contains 38 to 40 per cent of iron, 6 to 9 per cent of manganese, and on roasting yields metal averaging 60 per cent and an earthy residue of 12 per cent.

The reserves have been very carefully estimated in considerable detail by Einecke and Köhler..$^{70}$

\section{Iron resources of the Siegerland district.}

[Millions of metric tons.]

\begin{tabular}{|c|c|c|}
\hline & Ore. & Iron. \\
\hline $\begin{array}{l}\text { Known } \\
\text { Probable } \\
\text { Possible. }\end{array}$ & $\begin{array}{r}116 \\
50 \\
50\end{array}$ & $\begin{array}{l}42.92 \\
18.5 \\
18.5\end{array}$ \\
\hline
\end{tabular}

Lahn-Dill district. ${ }^{80}$-South of the Siegerland district lie the valuable deposits of the Lahn and Dill synclines. The ore is predominantly sedimentary hematite, which is supposed to have been deposited from iron-bearing vapors and solutions of volcanic origin beneath the sea. ${ }^{81}$ The ores in the Dill syncline are siliceous; those in the Lahn syncline are somewhat calcareous. Their content of iron is variable, averaging 48 per cent, according to Einecke and Köhler, though German official statistics show that as mined it is about 42 per cent.

Besides the hematite there are brown ores derived from it. The location of the deposits of both types is shown in Plate $X$. The estimate of reserves given by Einecke and Köhler ${ }^{82}$ is tabulated on page 78.

78 Einecke, G., and Köhler, W., op. cit., pp. 159-200. Bornhardt, W., Über die Gangverbältnisse des Slegerlandes und seine Umgebung: K.-preuss. geol. Landesanstalt Archiv für Lagerstättenforschungen, Heft 2, 1910. Lotz, H., Beltrag zur Kenntnis vom Alter der Siegerländer Erzgänge: Zeitschr. prakt. Geoogle, vol. 15, pp. 251-253, 1907. Resow, W., Das Ganggebietes des der "Eisenzecher Zuges": Zeltschr. prakt. Geologie, vol. 16, pp. 305-328, 1908.

10 Op. cit., p. 182.

${ }^{80}$ Beyschlag, F., Krusch, P., and Vogt, J. H. L., Die Lagerstätten der nutzbaren Mineralien und Gesteine, 2 vols., p. 1072, Stuttgart, F. Enke, 1913. Ennecke, G., and Köhler, W., op. cit., pp. 92-149.

81 Hatzfeld, C., Die Roteisensteinlager bel Fachingen an der Lahn: Zeitschr. prakt. Geologie, vol. 14, pp. 361-365, 1906. Krecke, F., Sind die Roteisensteinlager des nassauischen Devons primäro oder sckundäre Bildungen? Zeitschr. prakt. Geologic, vol. 12, pp. 348-355, 1904. Lotz, H., Dio Dillenburger Rotund Magneteisenerze: Deutsche geol. Gesell. Zeitschr., vol. 54, pp. 139-141, 1902. Rose, —-, Zur Frage der Entstehung der nassauischen Roteisensteinlager: Zeitschr. prakt. Geologie, vol. 16, pp. 497-501,1908. Harbort, E., Zur Frage nach der Entstehung gewisser devonischer Roteisenerzlagerstätten: Neues Jahrb., 1903, Band 1, pp. 179-192.

82 Op. cit., pp. 114-126. 
Iron resources of the Lahn and Dill synclines.

[Millions of metric tons.]

\begin{tabular}{|c|c|c|}
\hline . & Ore. & Iron. \\
\hline 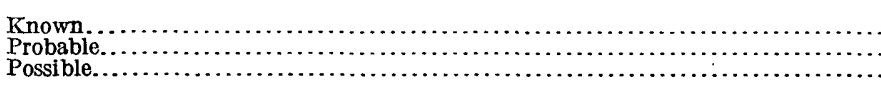 & $\begin{array}{c}166.0 \\
92.25 \\
100.00\end{array}$ & $\begin{array}{l}68.7 \\
36.9 \\
400\end{array}$ \\
\hline
\end{tabular}

Westerwald-Taunus-Vogelsberg district. ${ }^{83}$-Tertiary brown iron ores fill cavities in limestones in the Taunus and Vogelsberg hills and in the Westerwald region. Although not comparable in amount to larger deposits, they are a source of considerable ore of fair grade.

Iron reserves of the Taunus, Vogelsberg, and Westerwald regions.

[Millions of metric tons.]

\begin{tabular}{|c|c|c|}
\hline & Ore. & Iron. \\
\hline 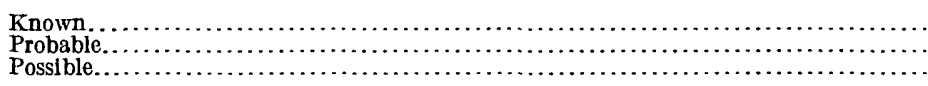 & $\begin{array}{r}15.7 \\
1.2 \\
15.3\end{array}$ & $\begin{array}{l}4.7 \\
0.4 \\
3.8\end{array}$ \\
\hline
\end{tabular}

Spessart. ${ }^{84}$-There is one other valuable group of deposits of iron ore in the East Rhine district-the metasomatic carbonate ores in the "Zechstein" formation of northwestern Spessart. The ores are easily mined and beneficiated, so that they are a cheap source of iron, although they contain only about 33 per cent of iron. A content of manganese amounting to 8 to 16 per cent adds to their value.

The estimate given by Einecke and Köhler ${ }^{85}$ covers only the ore that is immediately available, so that in the estimate below an arbitrary figure has been added for "possible" ore.

Iron resources of Spessart.

[Millions of metric tons.]

\begin{tabular}{|c|c|c|}
\hline & Ore. & Iron. \\
\hline 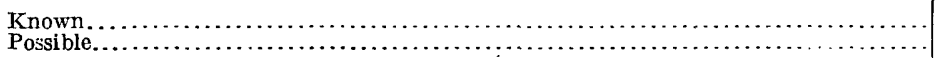 & $\begin{array}{l}3.5 \\
3.5\end{array}$ & $\begin{array}{l}1.2 \\
1.2\end{array}$ \\
\hline
\end{tabular}

83 Einecke, G., and Köhler, W., op. cit., pp. 216-232, 270-278, 636-666. Beyschlag, F., Die Eisenerze des Vogelberges: Zeitschr. prakt. Geologic, 1897, pp. 337-338. Bodifee, —, Über die Genesis der Eisen- und Manganerzvorkommen im Taunus: Zeitschr. prakt. Geologie, vol. 15, pp. 309-316, 1907. Chelius, C. R. L., Eisen und Mangan im Grossherzogtum Hessen, etc.: Zeitschr. prakt. Geologie, vol. 12. pp. 356-362, 1904. Delkeskampf, R., Die technisch nutzbaren Mineralien und Gesteine des Taunus: Zeitschr. prakt. Geologie, vol. 11, pp. 265-276, 1903. Münster, H., Die Brauneisenerzlagerstätten des Seen- und Ohmtals am Nordrand des Vogelgebirges: Zeitschr. prakt. Geologie, vol. 13, p $\rho .242-258,413,1905$. Vierschilling, A., Die Eisen- und Manganerzlagerstätten im Hunsrück und Soonwald: Zeitschr. prakt. Geologie, vol. 18, pp. 393-431, 1910.

84 Einecke, G., and Köhler, W., op. cit., pp. 480-590. Bücking, H., Der nordwestliche Spessart: K.preuss. geol. Landesanstalt A bh., neue Folge, Heft 12, p. 148, 1892.

op. cit., p. 489. 


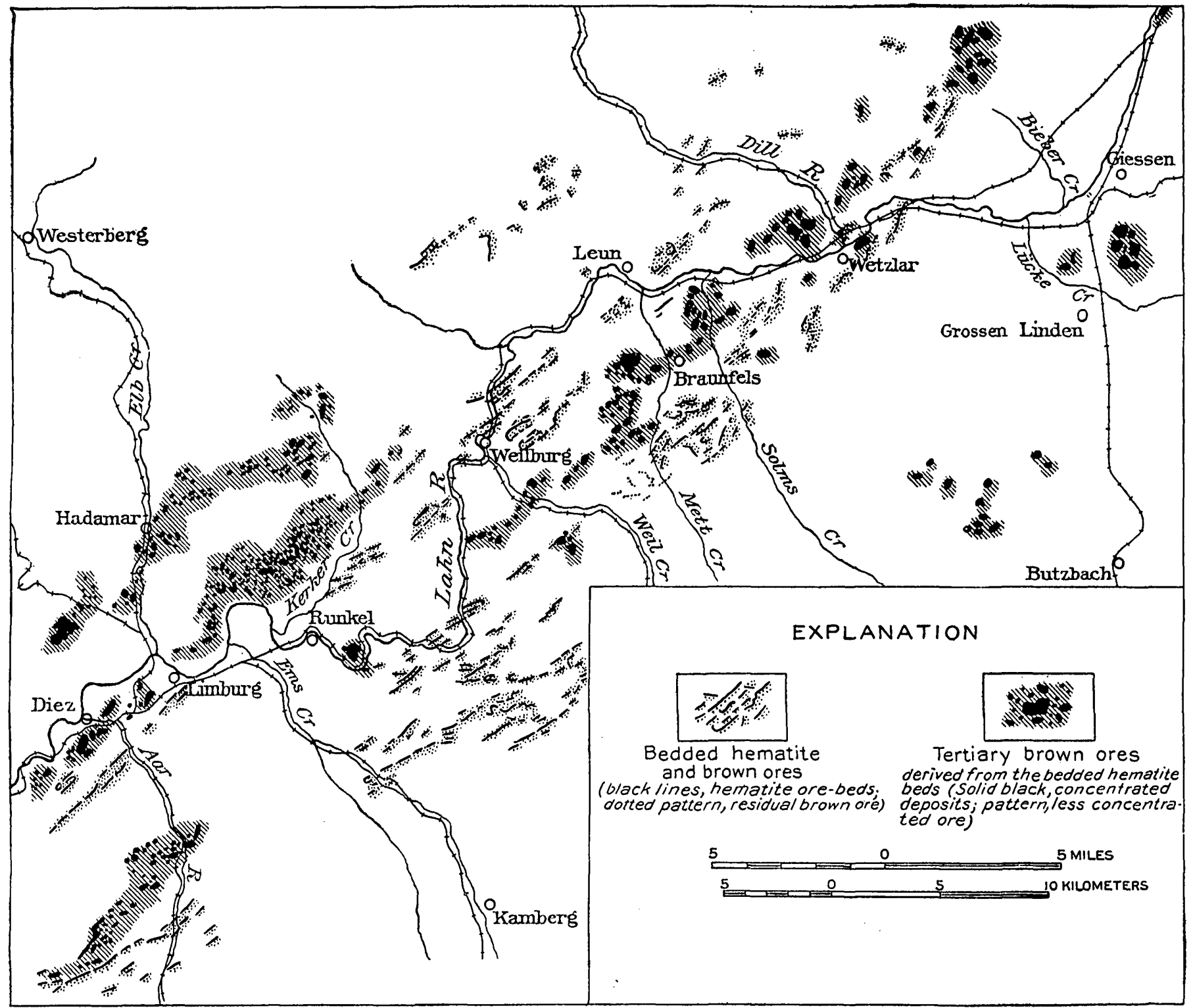

MAP SHOWING DISTRIBUTION OF IRON-ORE DEPOSITS IN THE LAHN-DILL DISTRICT, GERMANY. 
Summary.-The following figures sum up the reserves of metallic iron in the entire East Rhine district.

Iron resources of the East Rhine district.

[Millions of metric tons of iron.]

\begin{tabular}{|c|c|c|c|}
\hline • & Known. & Probable. & Fossible. \\
\hline 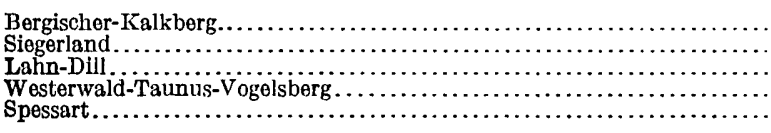 & $\begin{array}{r}1.4 \\
42.9 \\
68.7 \\
4.7 \\
1.2\end{array}$ & \begin{tabular}{r|r}
2.2 \\
18.5 \\
36.9 \\
0.4
\end{tabular} & $\begin{array}{r}1.6 \\
18.5 \\
40.0 \\
3.8 \\
1.2\end{array}$ \\
\hline & 118.9 & 58.0 & 65.1 \\
\hline
\end{tabular}

WESER DISTRICT.

Throughout the hills that form the middle part of the drainage basins of the Weser and the Ruhr, extending from Duisburg on the west eastward nearly to Magdeburg and southward to a point below Cassel, there are deposits of iron ore.

Salzgitter-Iselde region. ${ }^{80}$-The most valuable of the deposits of ore in the Weser district lie in the northern foothills of the Harz Mountains, in the Salzgitter-Iselde region in two synclines in Cretaceous rocks.

The deposits, which are of sedimentary origin, consist of brown iron-ore conglomerate cemented in places by oolitic material, and form sedimentary beds 20 to 30 meters thick. Their outcrop has been traced for 21 kilometers.

The ore is high in phosphorus and contains about 30 per cent of iron, as mined, and 12 per cent of moisture. Roasting gives a product whose iron content is about 40 per cent.

Einecke and Köhler, ${ }^{87}$ in calculating the reserves, considered only the ores immediately available and contented themselves with saying that the possibilities were "very considerable." Their figures were used for the "known" and "probable" ore, but the estimate of "possible" ore is based on the dimensions of the deposits given in their account.

Iron resources of the Salzgitter-Iselde region.

[Millions of metric tons.]

\begin{tabular}{|c|c|c|}
\hline & Ore. & Iron. \\
\hline 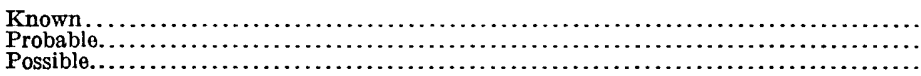 & $\begin{array}{r}248 \\
30 \\
1,000\end{array}$ & $\begin{array}{r}74.4 \\
9.0 \\
300.0\end{array}$ \\
\hline
\end{tabular}

80 Einecke, G., and Köhler, W., op. cit., pp. 350-390.

87 Idem., p. 387. 
Harz Mountains ${ }^{8}$ - In the Harz Mountains there are many deposits of iron ore. The most extensive are the deposits of hematite and those of brown ores derived from it near Elbingerode and Hüttenrode. They are sedimentary deposits and are similar to the LahnDill ores in occurrence. There are also sedimentary hematite ores in the Devonian rocks of the Upper Harz and carbonate veins in the southern Harz.

Iron resources of the Harz Mountains

[Millions of metric tons.]

\begin{tabular}{|c|c|c|}
\hline & Ore. & Iron. \\
\hline 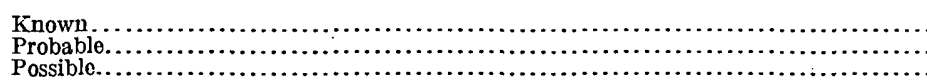 & $\begin{array}{l}20.5 \\
22.1 \\
55.0\end{array}$ & $\begin{array}{r}9.2 \\
8.9 \\
21.8\end{array}$ \\
\hline
\end{tabular}

Kellerwald-Sauerland region.-In the southern part of the Weser district there is a continuation of the ore deposits of the Lahn-Dill district. The ores are hematite and brown ores derived from hematite in Devonian sediments. ${ }^{80}$

Iron resources of the Kellerwald-Sauerland region.

[Millions of metric tons.]

\begin{tabular}{|c|c|c|}
\hline . & Ore. & Iron. \\
\hline $\begin{array}{l}\text { Known.......... } \\
\text { Possible........... }\end{array}$ & $\begin{array}{l}4 \\
8\end{array}$ & $\begin{array}{l}1.1 \\
2.2\end{array}$ \\
\hline
\end{tabular}

Lower Hesse.90-Ore of a different type is found at Mardorf Zwesten and Schieffelborn, in Lower Hesse. It is residual pisolitic brown ore called "bohnerz."

\begin{tabular}{|c|c|c|}
\hline . & Ore. & Iron. \\
\hline 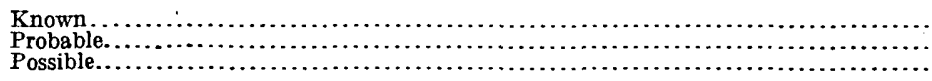 & $\begin{array}{l}1.5 \\
1.0 \\
2.0\end{array}$ & $\begin{array}{r}0.6 \\
.3 \\
.7\end{array}$ \\
\hline
\end{tabular}

Bentheim-Ochtrup-Ottenstein region. ${ }^{91}$-In the northwest corner of the Weser district some clay ironstone ores lie in thin seams in Cretaceous clays. They are not worked at present, but slight changes

${ }^{88}$ Ermisch, K., Die Knollengrube bei Lauterberg am Harz: Zeitschr. prakt. Geologie, vol. 12, pp. 160-172, 1904. Einecke, G., and Köhler, W., op. cit., pp. 390-431.

89 Einecke, G., and Köhler, W., op. cit., p. 428.

o0 Idem, pp. 472-480.

91 Krusch, P., Die Eisenerzvorkommen der untern Kreide im Westen des Beckers von Münster, etc.: Glückauf, vol. 54, pp. 261-268, Apr. 27, 1918. Willert, -, Das Toneisensteinvorkommen von Ahaus und Koesfeld [Bentheim-Ochtrup-Ottenstein]: Glückauf, vol. 44, pt. 1, pp. 304-309, 1908. Einecke, G., and Köhler, W., op. cit., pp. 278-301. 
in practice might make them available, so they can not be neglected as a reserve. In fact, German experts have lately been giving these ores renewed attention in the hope of finding a way to use them. The reserve figures given below are based on the estimate made by Einecke and Köhler. ${ }^{22}$

Iron resources of the Bentheim-Ochtrup-Ottenstein region.

[Millions of metric tons.]

\begin{tabular}{|c|c|c|}
\hline & Ore. & Iron. . \\
\hline $\begin{array}{l}\text { Probable } \ldots \ldots \ldots \ldots \ldots \\
\text { Possible.................... }\end{array}$ & $\begin{array}{r}15 \\
200\end{array}$ & $\begin{array}{r}4.5 \\
60.0\end{array}$ \\
\hline
\end{tabular}

Teutoburger Wald and Wesergebirge areas.-There are many iron-ore deposits in the Teutoburger forest, but only a few of them are worth noting. The brown ores of Hüggel and the carbonate ores of Schafberg and the brown ores derived from them are now mined. Besides these some clay ironstones occur in the Wittekind formation, and a ferruginous limestone, which contains 18 per cent of iron and is used as a flux, occurs in the Wesergebirge district.

The estimates of Einecke and Köhler ${ }^{93}$ indicate the reserves tabulated below.

Iron resources of the Teutoburger Wald and Wesergebirge areas.

[Millions of metric tons.]

\begin{tabular}{|c|c|c|}
\hline & Ore. & Iron. \\
\hline 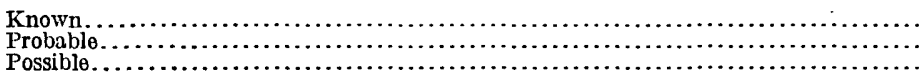 & $\begin{array}{r}20.5 \\
23.5 \\
100.0\end{array}$ & $\begin{array}{r}7.2 \\
7.8 \\
18.0\end{array}$ \\
\hline
\end{tabular}

Oolitic ores.-Besides the deposits specially mentioned, there occur through the Weser district small islands of oolitic ore similar to the minette ores of Lorraine. ${ }^{94}$ These ores occur in islands of the same Jurassic horizon as the Lorraine ores. Although the individual occurrences are small the aggregate reserve is considerable.

Iron resources in oolitic ores in the Weser district.

[Millions of metric tons.]

\begin{tabular}{|c|c|c|}
\hline & Ore. & Iron. \\
\hline 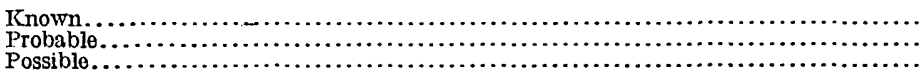 & $\begin{array}{r}20 \\
25 \\
100\end{array}$ & $\begin{array}{r}6.4 \\
8.0 \\
32.0\end{array}$ \\
\hline
\end{tabular}

92 Op. cit., p. 298.

${ }^{93}$ Idem, p. 347.

94 Idem, pp. 492-527. 15945-21-Bull. $706-6$ 
Summary of the Weser district.-The quantity of iron in the Weser district is summarized below.

Iron resources of the Weser district.

[Millions of metric tons of iron.]

\begin{tabular}{|c|c|c|c|}
\hline & Known. & $\begin{array}{c}\text { Prob- } \\
\text { able. }\end{array}$ & $\begin{array}{l}\text { Pos- } \\
\text { sible. }\end{array}$ \\
\hline 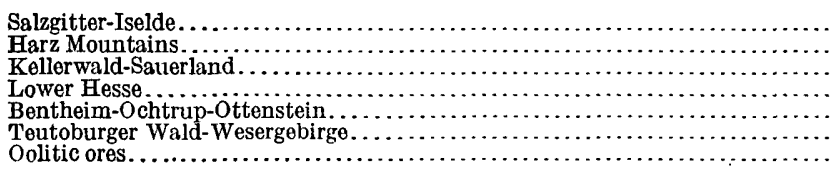 & $\begin{array}{r}74.4 \\
9.2 \\
1.1 \\
0.6 \\
7.2 \\
6.4\end{array}$ & $\begin{array}{r}9.0 \\
8.9 \\
0.3 \\
4.5 \\
7.8 \\
8.0\end{array}$ & $\begin{array}{r}300.0 \\
21.8 \\
2.2 \\
0.7 \\
60.0 \\
18.0 \\
32.0\end{array}$ \\
\hline & 98.9 & 38.5 & 434.7 \\
\hline
\end{tabular}

NORTH AND CENTRAL GERMANY. ${ }^{95}$

Throughout the plains of north and central Germany there are deposits of bog iron which in 1913 yielded 36,350 tons of ore. Many of those in the northwestern part are exhausted, as are also those in Upper Silesia. Some of them have gone to Poland with the territory in Posen and West Prussia. An estimate of what remains to Germany is given below.

Iron resources of north and central Germany.

[Millions of metric tons.]

\begin{tabular}{|c|c|c|}
\hline & Ore. & Iron. \\
\hline $\begin{array}{l}\text { Known } \\
\text { Probable } \\
\text { Possible } \ldots \ldots \ldots \ldots \\
\text { Pow }\end{array}$ & $\begin{array}{l}8 \\
8 \\
8\end{array}$ & $\begin{array}{l}2.4 \\
2.4 \\
2.4\end{array}$ \\
\hline
\end{tabular}

THURINGIA. ${ }^{96}$

In the older formations of the Thuringian forest there are several kinds of iron deposits. In the Cambrian rocks at Schmiedefeld ${ }^{07}$ there are contact-metamorphic deposits of magnetite in limestone next to granite. In the Silurian of the eastern part of the forest there are large beds of oolitic chamosite. ${ }^{98} \quad$ Einecke and Köhler describe the ore as a somewhat argillaceous and siliceous carbonate.

\footnotetext{
95 Finecke, G., and Köhler, W., op. cit., pp. 527-530. Eisenerze in Schlesien und Posen: Zeitschr. prakt. Geologie, vol, 14, p. 62, 1906.

${ }_{96}$ Einecke, G., and Köhler, W., op. cit., pp. 431-472. Beyschlag, F., Die Erzlagerstätten der Umgebung von Kamsdorf in Thüringen: K. preuss. geol. Landesanstalt Jahrb., 1888, pp. 329-377. I.oretz, H., Der Zechstein in der Gegend von Blankenburg und Königsee (Thüringerwald): K.-preuss. geol. Landesanstalt Jahrb., 1889, pp. 221-245. Lowag, J., Mangan und Eisenerzvorkommen im Thüringerwalde: Oesterr. Zeitschr. Berg- u. Hüttenwesen, vol. 50, pp. 608-611, 623-625, 635-636, 1902. Russwurm, —, Neue Aufschlüsse von Magneteisenerz im Thüringerwalde: Glückauf, vol. 43, pt. 1, pp. 163-164, 1907.

${ }^{97}$ Schlegel, Karl, Das Magneteisenerzlager vom Schwarzen Krux bei Schmiedefeld: Deutsch. geol. Gesell. Zeitschr., vol 54, pp. 24-55, 1902.

98 Zalinski, E. R., Untersuchungen über Thuringit und Chạmọsit ạus Thuụringen: Neues Jahrb., Beỉ. lage Band, vol. 19, pp. 40-84, 1904,
} 
De Launay (after Loretz) ${ }^{99}$ says that it is composed of oolitic grains of chamosite, with some thuringite, cemented by iron carbonate and lime carbonate. After it is roasted the ore is of about 45 per cent grade and high in phosphorus. Unlike other German ores it contains a little titanium dioxide (1.4 to 1.8 per cent).

The production of iron ore in the Thüringerwald in 1913 was 280,200 tons.

Iron resources of the Thuringian forest.

[Millions of motric tons.]

\begin{tabular}{|c|c|c|}
\hline & Ore. & Iron. \\
\hline 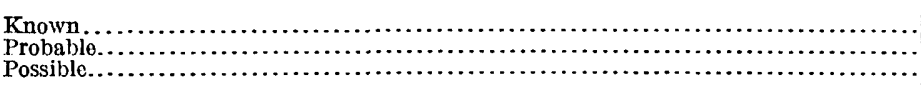 & $\begin{array}{r}52.0 \\
52.3 \\
105.0\end{array}$ & $\begin{array}{l}15.9 \\
13.5 \\
27.3\end{array}$ \\
\hline
\end{tabular}

BAVARIA AND WÜRTTEMBERG. ${ }^{1}$

In the Jurassic sediments of the Swabian and Bavarian Alps there are brown ores of several types. The location of some of the deposits is shown in figure 22 . They are partly intercalated oolites, partly

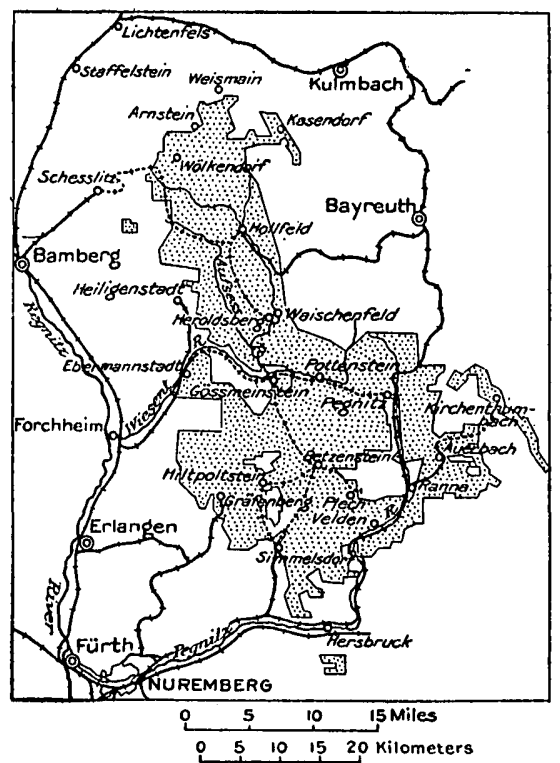

Frgure 22.-Sketch map showing areas of developed iron ore in the Franconian Alps, Bavaria. (From Einecke, G., and Köhler, W., op. cit.)

${ }^{93}$ Loretz, H., Der Zechstein in der Gegend von Blankenburg und Königsee (Tharingerwald): K.-preuss. geol. Anstalt Jahrb., 1889, pp. 221-245.

1 Einecke, G., and Köhler, W., op. cit., pp. 590-631. Fluhr, R., Die Eisenerzlagerstätten Württembergs: Zeitschr. prakt. Geologie, vol. 16, pp. 1-23, 1908. Holzapfel, E., Die Eisenerzvorkommen in der Fränkischen Alb: Glückauf, vol. 46, pt. 1, pp. 341-350, 1910. Rothpletz, A., Über die Amberger Erzformation: Zeitschr. prakt. Geologie, vol. 21, pp. 249-260, 1913. Schmidt, A., Württomberg's Erzbergbau in der Vergangenheit: Glückauf, vol. 43, pt.2. pp. 1034-1042,1607. 
replacement deposits, and to some extent are of residual origin. These ores have been receiving considerable attention in recent years and bid fair to become one of the most important of Germany's reserves. They are of immense extent and their possible value seems very large in spite of the fact that they contain too much silica for general use. The production in 1913 was 498,900 tons.

Iron resources of Bavaria and Württemberg.

[Millions of metric tons.]

\begin{tabular}{|c|c|c|}
\hline & Ore. & Iron. \\
\hline 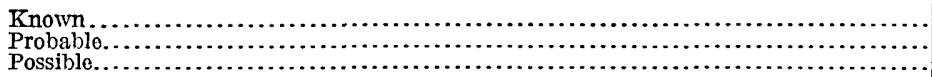 & $\begin{array}{r}42 \\
250 \\
1,100\end{array}$ & $\begin{array}{r}17.9 \\
92.0 \\
382.0\end{array}$ \\
\hline
\end{tabular}

SCHMIEDEBERG. ${ }^{2}$

At Schmiedeberg, in the part of Silesia left to Germany, lies a high-grade deposit of magnetite ore of igneous origin.

Iron resources of Schmiedeberg, Germany.

[Millions of metric tons.]

\begin{tabular}{|c|c|c|}
\hline & Ore. & Iron. \\
\hline Rnown & $\begin{array}{l}0.6 \\
2.0\end{array}$ & $\begin{array}{l}0.3 \\
1.0\end{array}$ \\
\hline
\end{tabular}

SUMMARY OF GERMAN IRON RESERVES.

The iron resources of Germany are summarized by districts below.

Iron resources of Germany.

[Millions of metric tons of iron. Compare Fl. VIII, in pocket.]

\begin{tabular}{|c|c|c|c|}
\hline & Known. & Probable. & Possible. \\
\hline \multirow[t]{2}{*}{ 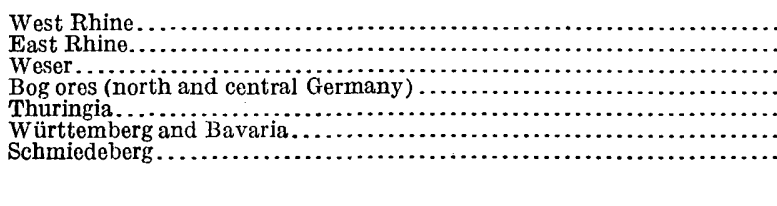 } & $\begin{array}{r}1.3 \\
118.9 \\
98.9 \\
2.4 \\
15.9 \\
17.9 \\
.3\end{array}$ & \begin{tabular}{r|r}
2.0 \\
58.0 \\
38.5 \\
2.4 \\
13.5 \\
92.0 \\
1.0
\end{tabular} & $\begin{array}{r}0.2 \\
65.1 \\
434.7 \\
27.4 \\
27.3 \\
382.0\end{array}$ \\
\hline & 255.6 & 207.4 & 911.7 \\
\hline
\end{tabular}

\section{PRODUCTION AND CONSUMPTION.}

The steady increase in the production of iron ore in the German Customs Union, which advances at a somewhat slower rate than that of the United States but faster than Europe as a whole, is shown in figure 23.

\& Berg, G., Die Magneteisenerzlager von Schmiedeberg: K.-preuss. geol. Landesanstalt Jahrb., 1902,pp. 201-266. Einecke, G., and Köhler, W., op. cit., pp. 572-576, 
The slowly increasing relative importance as well as the predominant position of the minette ores of Lorraine Annexée is shown in figure 24 .

In 1913 the production of iron ore in Germany and Luxemburg together amounted to 33 per cent and the consumption to 43.5 per cent of the total in Europe. Of the ore produced in the German Customs Union Luxemburg produced 20.5 per cent, Lorraine Annexée 59 per cent, and the rest of Germany 20.5 per cent.

The latest available statistics (those for 1912) show that of the total ore consumed Luxemburg used 19.1 per cent, German Lorraine 24.5 per cent, Prussia 53.7 per cent, Bavaria 0.9 per cent, and the rest of Germany 1.8 per cent. The last three items, representing the consumption of new Germany, aggregate 66.4 per cent.

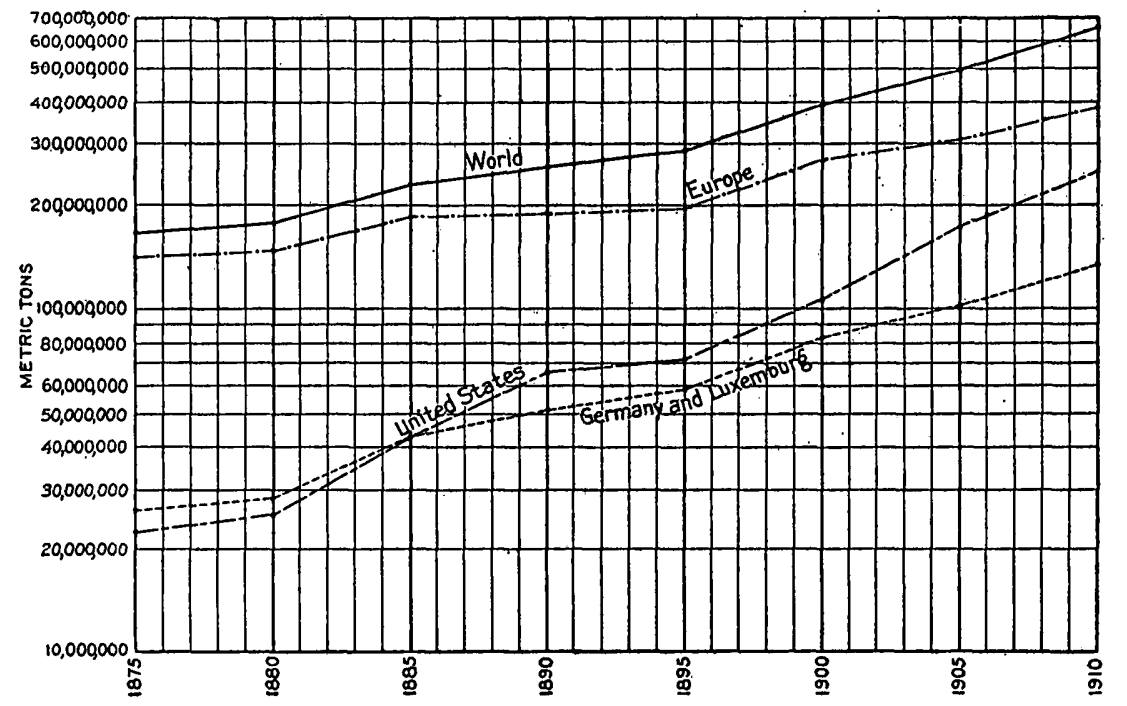

Figure 23.-Ratio chart showing iron ore produced during flve-year periods ending 1875 to 1910 in the German Customs Union, Europe, the United States, and the world. (See explanation of fig. 8, p. 41.)

The indicated capacity of the German Republic to produce iron ore is only 20.5 per cent of the capacity of the former German Customs Union, whereas its indicated capacity of consumption is 56.4 per cent of the capacity of the former German Customs Union. Thus, in order to continue the iron and steel industry of the territory now remaining at the same rate as before the war, Germany must import a much larger proportion of the ore required than in the past. If artificial barriers are erected against this importation the iron industry of Germany will decline and ul timate consumers in other countries will lose a source of cheap iron and steel. 
Germany's reserves of ore still appear to be fairly extensive, but she has no iron-ore producing districts that rank with those that have been lost. The following table, based on official statistics, ${ }^{3}$

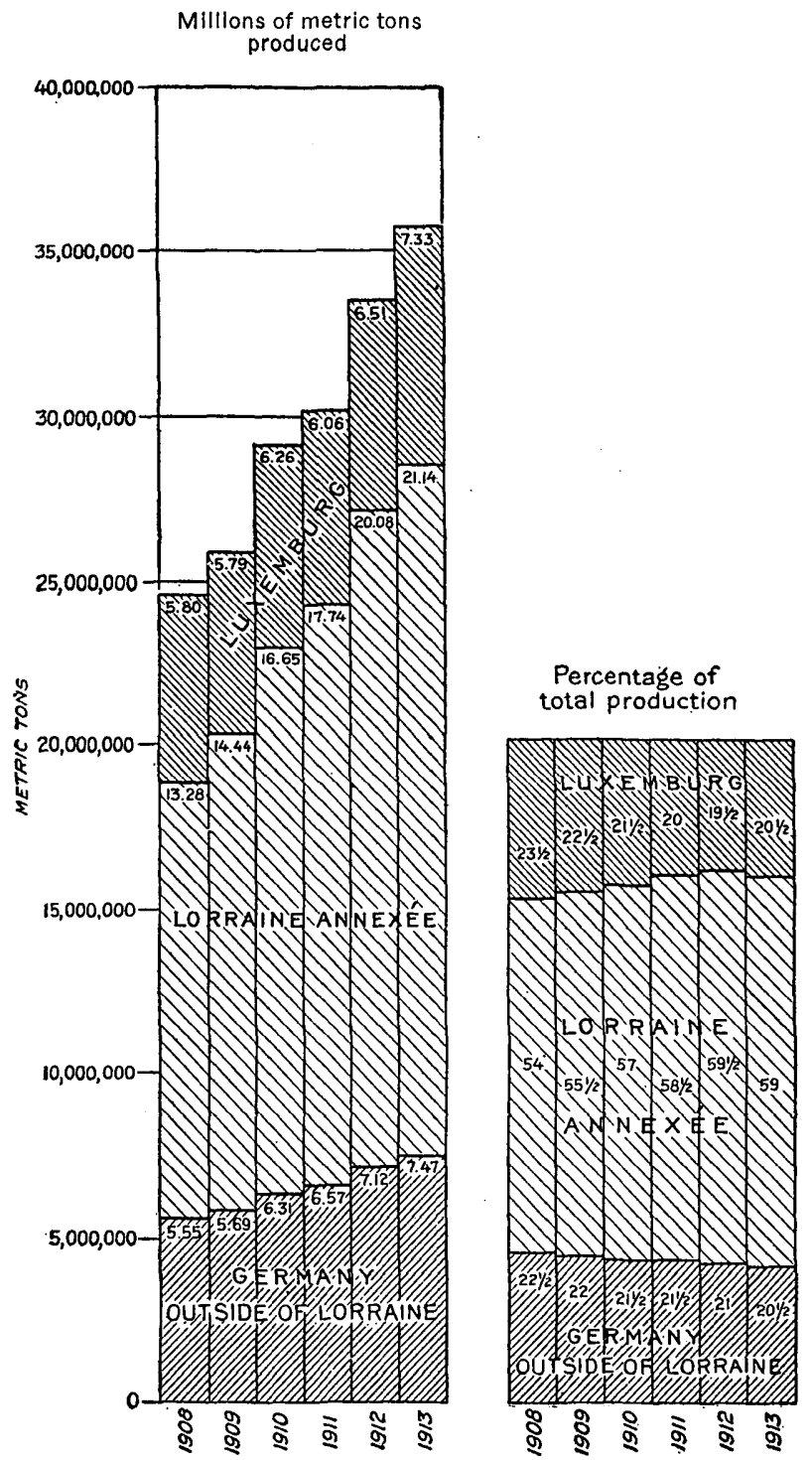

FIGURE 24,-Diagrams showing iron ore produced annually in the German Customs Union, 1908-1913, and the quantities and proportions contributed by Luxemburg, Lorraine Annexée, and German mines outside of Lorraine.

shows the quantity of iron in the ore mined per man per year in the remaining districts of Germany:

Vierteljahrshefte zur Statistik des deutschen Reichs. 
Metric tons of iron in iron ore mined per man per year in certain districts in Germany.

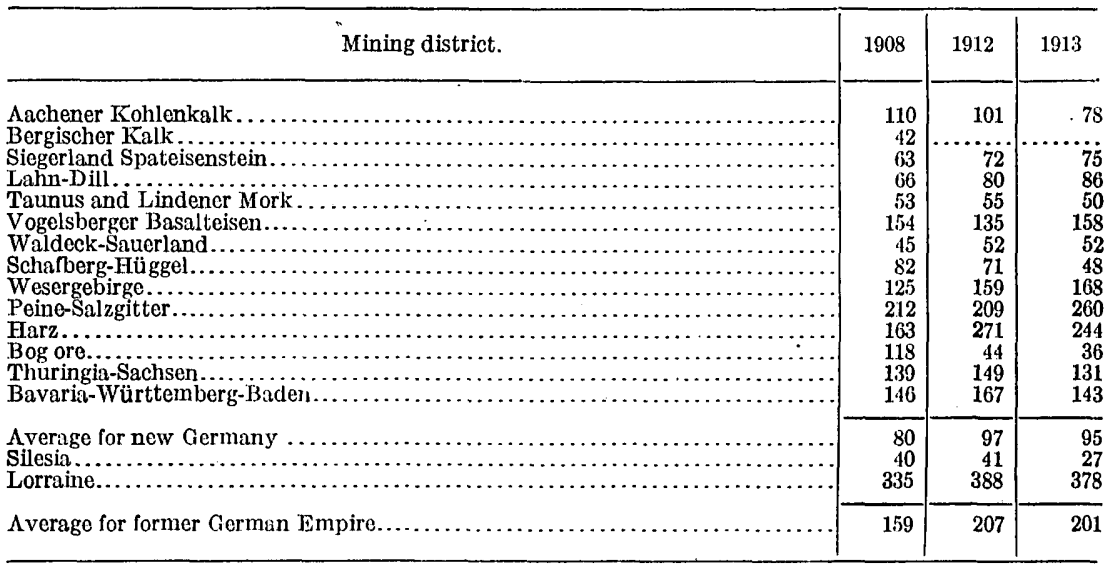

In spite of all that Germany has lost and the poor sort of ore that remains she has, in the coking coal of Westphalia, in her undamaged furnaces, and in her known genius for work, resources that assure her a strong position in the world's iron and steel industry. The near future, with formidable economic barriers and with markets dulled by social unrest and domestic disturbance, may be very dark, but enmity and social unrest can not prevail forever against Europe's need of iron.

\section{SWITZERLAND. 4}

\section{DISTRIBUTION, CHARACTER, AND EXTENT OF THE DEPOSITS.}

The iron ores of Switzerland are of more interest to the historian than to the economist, for most of the deposits are so situated that they can not be exploited economically. (See Pl. VIII, in pocket.)

Jura Mountains. ${ }^{5}$-In the Jura Mountains of western Switzerland are found the so-called "Bohnerze"-pisolitic ores derived from Mesozoic iron-bearing limestones by superficial disintegration during the Eocene epoch. They are low-grade, slightly titaniferous ores which contain 42 per cent of iron after washing. In 1910 this ore was being mined near Delsberg at the rate of about 6,500 tons a year.

It is difficult to estimate the reserves of ore of this type, because its occurrence is extremely irregular. C. Schmidt ${ }^{6}$ says that about $1,000,000$ tons are known. As transportation is not considered another million may be estimated as "possible."

ه Schmidt, C., Bericht über die Eisenerzvorräte der Schweiz: The iron-ore resources of the world (11th Internat. Geol. Cong.), vol. 1, pp. 105-141, Stockholm, 1910. Hotz, W., Die Lagerstiitten der nutzbaren Mineralien in der Schweiz: Zeitschr. prakt. Geologie, vol. 17, pp. 29-42, map, 1909.

6 Fleury, E., Le fer et le terrain sidérolithique dans le Jura bernois: Soc. fribourgeoise sci. nat. Bull., vol. 12, pp. 29-33, 1904; abstract in Inst. Min. Eng. Trans., vol. 29, pp. 690-691, 1904-1905.

o Schmidt, C. [Mining in Canton Wallis], reviewed in Zeitschr. prakt. Geologie, vol. 11, pp. 205-208, 1803. 
Iron resources of the Jura Mountains, Switzerland.

[Millions of metric tons.]

\begin{tabular}{|c|c|c|}
\hline & Ore. & Iron. \\
\hline $\begin{array}{l}\text { Known.... } \\
\text { Possible... }\end{array}$ & $\frac{1}{1}$ & $\begin{array}{r}0.4 \\
.4\end{array}$ \\
\hline
\end{tabular}

Mont Chemin. - In the metamorphic rocks of Mont Chemin, a part of the mass of Mont Blanc, particularly in the marble, there are lenses of magnetite and hornblende. The material is of rather good grade but is negligible as a reserve.

Avers. ${ }^{8}$ - In the Triassic limestone and associated porphyry of the valley of Avers there are intercalated beds of siderite and hematite. They are of only historical importance.

Gonzen. ${ }^{2}-J u r a s s i c$ sedimentary ores, which, singularly, lack oolitic structure, are found near Gonzen. They are of good grade, are more or less manganiferous, but are insignificant in quantity.

Chamoson and Erzegg-Planplatten. ${ }^{10}$-Jurassic ores also occur at Chamoson and in the Erzegg-Planplatten area. They are oolitic and siliceous. The ore minerals are chamosite and siderite. Their average iron content is 30 per cent.

Iron resources of Chamoson and of the Erzegg-Planplatten area.

[Millions of metric tons.]

\begin{tabular}{|c|c|c|}
\hline & Ore. & Tron. \\
\hline 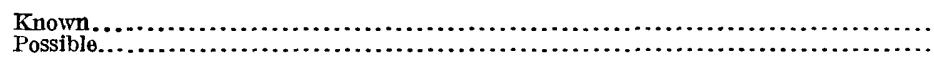 & $\begin{array}{l}2.5 \\
2.5\end{array}$ & $\begin{array}{r}0.8 \\
.8\end{array}$ \\
\hline
\end{tabular}

Other deposits.-There are many small and inaccessible deposits in Switzerland that together can be considered as affording a possible reserve of a million tons of iron.

Summary for Switzerland.-The quantities of iron in the ore deposits of the region indicated are summarized below:

Iron resources of Switzerland.

[Millions of metric tens of iron.]

\begin{tabular}{|c|c|c|}
\hline & Known. & Possible. \\
\hline 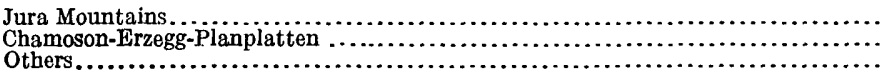 & $\begin{array}{r}0.4 \\
.8 \\
\cdots\end{array}$ & $\begin{array}{l}0.4 \\
.8 \\
1.0\end{array}$ \\
\hline & 1.2 & 2.2 \\
\hline
\end{tabular}

7 Schmidt, C. [Mining in Canton Wallis], reviewed in Zeitschr. prakt. Geologie, vol. 11, pp. 205-208, 1903.

8 Heim, A., Über die Erze des Avers und Oberhalbsteintal in Graubinden (abstract): Geol. Centralbl., vol. 1, p. 740, 1901.

- Wencélius, A., Eisen und Manganerzgruben der Schweiz: Berg- u. Hüttenm. Zeitung, vol. 62, pp. 541$545,1903$.

10 Idem. 


\section{PRODUCTION AND CONSUMPTION.}

Switzerland mines no iron ores, and her deposits are so inaccessible that she is not likely to develop an iron-mining industry.

\section{ITALY."}

\section{DISTRIBUTION, CHARACTER, AND EXTENT OF THE DEPOSITS.}

Italy is nearly self-supporting as to iron ore. She obtains most of her ore from the island of Elba. (See Pl. XI, in pocket.)

$E l b a .^{12}$ - The famous high-grade, low-phosphorus ores of Elba occur in metamorphic rocks of pre-Silurian to Eocene age. According to De Launay ${ }^{13}$ the ores are vein and metasomatic deposits associated with granitic intrusives. Later metamorphism has tended to make them appear more complex. The ore minerals are oxides (magnetite, hematite, and ferric hydrates) near the surface and contain increasing amounts of sulphides with increase in depth.

The reserves were estimated at 7,500,000 tons in 1904. From 1904 until January 1, 1909, 1,240,000 tons were mined. Since then about 500,000 tons a year has been mined, or about 6,250,000 tons from 1904 to 1919 , so that about $1,250,000$ tons are left in the deposits. Allowing for development work there are probably about 2,500,000 tons of ore containing $1,100,000$ tons of iron on the island that fall into the class of "known" ores.

Sardinia. ${ }^{14}$-According to recent information, examinations stimulated by war needs have proved that $6,000,000$ tons of ore occur in Sardinia, in the Nurra district, at the north end of the island. These ores are sedimentary and oolitic. Their average content of iron is about 45 per cent, so that it seems fair to credit the deposits with probable reserves amounting to $6,000,000$ metric tons of ore containing 2,700,000 tons of iron.

At Ogliastra, between the Bay of Orosei and the Gulf of Cagliari, there are bedded deposits of brown ore. Their value is doubtful.

At San Leone there are veins of magnetite which are supposed to contain 875,000 tons of good ore, and near Iglesias there is a bed of brown ore and magnetite which contains about 60,000 tons.

Altogether the deposits in Sardinia can be credited with a "probable" reserve of about $3,333,000$ tons of iron.

11 Aichino, Giovanni, Note sur les ressources en minerai de fer de l'Italie: The iron-ore resources of the world (11 th Internat. Geol. Cong.), vol. 1, pp. 93-105, Stockholm, 1910.

1 Capacci, C., The iron mines of the island of Elba: Iron and Steel Inst. Jour., 1911, No. 2, pp. 412-450, with map. Poech, F., Die Eisenindustrie auf der Insel Elba: Oesterr. Zeitschr. Berg- u. Hüttenwesen, vol. 51, pp. 365-371. 1903. Sevieri, V., Analyses of Elba ore: Rassegna mineraria, vol. 14, pp. 101-102.

${ }^{18}$ Launay, L. de, Gites mineraux et metallifères, vol. 2, pp. 400-408, Faris, Ch. Béranger,1913.

14 Duenkel, - - Berichte über eine im Jahre 1000 ausgeführte Bereisung der Insel Sardinien und einiger anderer Bergreviere Italiens: Zeitschr. Berg-, Hütten- u. Salinenwesen preuss. St., vol. 50, pp. 622-668, 1902. Testa, L., The iron-ore deposits of Sardinia: Iron and Steel Inst. Jour., 1911, No. 2, pp. 364-379 
Val d'Aosta. ${ }^{15}$ - In the Val d'Aosta, in the Piedmont country near the French border, there are lenses of magnetite in serpentine, which very clearly seem to have been formed by magmatic segregation. The ore is of extremely high grade and is low in phosphorus.

Recent estimates place the reserves of ore at $1,000,000$ tons for the deposits of Traversella and 5,000,000 tons for those at Cogne. The total for Val d'Aosta can be taken as 3,600,000 metric tons of metallic iron.

Bergamo-Brescia. ${ }^{16}$ - - In the Brembana Valley there are replacement veins in beds of siderite. They have furnished low-phosphorus ore for many years, but as the Italian Metallurgical Association estimates the reserve at only 20,000 tons they may be dismissed as unimportant.

Central Italy. ${ }^{17}$-Brown ores are found in Central Italy, in the Versilia district, at Campiglia Maritimma, at Massa Maritimma Orbetello, and at Tolfa.

They are credited with a reserve of $2,000,000$ tons of ore, or about 800,000 tons of metal.

Miscellaneous.-Iron ore is reported to occur at Stilo, ${ }^{18}$ in southern Italy, and at Monte Peloritani, in Sicily. ${ }^{19}$ Its quantity does not seem to be large.

Summary for Italy.-The quantities of metallic iron in the deposits of Italy are summarized below.

Iron resources of Italy.

[Millions of metric tons of iron. Compare Pl. $\dot{X} I$, in pocket.]

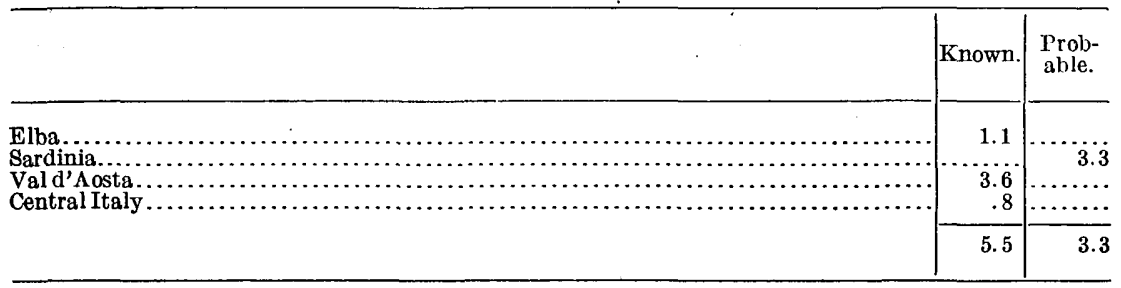

15 Catani, R., The iron-ore deposits of Piedmont: Iron and Steel Inst. Jour., 1911, No. 2, pp. 353-363. Bonney, T. G., The magnetite mines near Cogne: Geol. Soc. London Quart. Jour., vol. 59, pp. 55-63, 1903. Müller, F. C., Die Erzlagerstätten von Traversella im Piemont: Zeitschr. prakt. Geologie, vol. 20, pp. 209-240 (with geologic map), 1912. Peters, F., La Valée d'Aoste et ses principaux gites métallifères: Rev. univ. mines, vol. 39-40, pp. 97-116, 1912.

${ }^{16}$ Calvi, G., The production of iron ores in the.Brembana Valley: Ir on and Steel Inst. Jour., 1911, No. 2, pp. 380-389.

17 Ciampi, A., The iron-ore deposits of central Italy: Iron and Steel Inst. Jour., 1911, No. 2, pp. 390-408. Ristori, G., I giacimenti limonitici (Campiglia Marittima): Soc. toscana sci. nat. Atti, vol. 20, pp. 60-75, 1904 .

${ }^{18} \mathrm{La}$ Valle, G., On the iron-ore deposits of southern Italy and Sicily: Iron and Steel Inst. Jour., 1911, No. 2, pp. 409-411.

${ }^{19}$ Lotti, B., Die geologischen und tektonischen Verhältnisse der Erzlagerstätten Nordost-Siziliens: Zeitschr. prakt. Geologie, vol. 15, pp. 62-66, 1907. 


\section{PRODUCTION AND CONSUMPTION.}

Since the beginning of the twentieth century Italy's production of iron ore has been increasing at a rate consonant with that of the United States and has been ahead of the European rate. Both her production and her consumption of iron ore amount to about 0.5 per cent of the total European consumption and production. In addition she utilizes large quantities of scrap iron and imported pig iron, so that she produces about twice as much steel as pig iron. By the use of electro-metallurgy she is building up the iron industry in her mountain Provinces to an extraordinary degree.

Italy shows what can be done by energetic industry without large domestic reserves. The fuel she uses for her metallurgic work is of foreign origin except as she uses heat generated by electricity, and as she has not enough ore she imports pig iron to supply her needs.

Statistics of the iron industry in Italy in $1919 .{ }^{20}$

\begin{tabular}{|c|c|}
\hline Iron ore produced. & $\begin{array}{r}\text { Metric tons. } \\
603,116\end{array}$ \\
\hline Pig iron produced. & 385,340 \\
\hline Steel produced.... & 846,085 \\
\hline Coal (anthracite and lignite) produced. & $701,081$. \\
\hline Coal imported.. & $10,834,008$ \\
\hline Coke produced. & $1,336,382$ \\
\hline Pig iron imported. . . . . . . . & 221,688 \\
\hline Iron and steel scrap imported. . . . . . & 326,231 . \\
\hline Iron ore imported............ & 8,026 \\
\hline Iron ore exported $\ldots \ldots \ldots \ldots \ldots \ldots \ldots \ldots \ldots \ldots \ldots \ldots \ldots \ldots \ldots \ldots$ & 9,660 \\
\hline Pig iron exported.$\ldots \ldots \ldots \ldots \ldots \ldots \ldots \ldots \ldots \ldots \ldots \ldots \ldots$ & 555 \\
\hline Scrap exported $\ldots \ldots \ldots \ldots \ldots \ldots \ldots \ldots \ldots \ldots \ldots \ldots \ldots \ldots \ldots \ldots$ & 6,895 \\
\hline
\end{tabular}

Recent changes in the map of Europe do not affect Italy's supply of ore, but unless there is a change in the present ominous state of the coal industry in Great Britain she must look to Germany or to the United States to supply her deficiency of coal.

\section{NORWAY. ${ }^{21}$}

\section{DISTRIBUTION, CHARACTER, AND EXTENT OF THE DEPOSITS.}

The iron-ore deposits of Norway (see Pl. XII, in pocket) are difficult to classify. Whatever may have been their origin they are composed of minerals that are formed deep in the earth's crust-magnetite, or magnetite and hematite. Those in which ilmenite is found with

20 Mineral Industry, 1915.

${ }^{21}$ Vogt, J. H. L., Die Eisenerzvorräte Norwegens: The iron-ore resources of the world (11th Internat. Geol. Cong.), vol. 2, pp. 603-621, Stockholm, 1910. Launay, I. de, L'origine etles caractères des gisements defer scandinaves: Annales des mines, vol. 4, pp. 49-106, 109-211, 1903. Nicou, P., Etude sur les minerais de fer scandinaves: Annales des mines, vol. 19, pp. 85-174, 177-240, 249-378, 1911. Sjögren, H., The geological relations of the Scandinavian iron ores: Am. Inst. Min. Eng. Trans., vol. 38, pp. 766-836, 1907. Vogt, J. H. L., Norges Jernnalinforekomster: Norges geol. Undersökelse, No. 51, pp. 1-225, 1910. 
magnetite are associated with gabbros, diabases, and nepheline syenites. They are clearly of igneous origin. The small deposits of southern Norway are of contact-metamorphic origin.

Most of the Norwegian ores occur in a complex of metamorphosed early Paleozoic rocks. The ore minerals are magnetite and hematite and the gangue contains garnet and vesuvianite. Deep-seated metamorphism has in part determined the form and the mineral composition of the deposits and has obscured or concealed their mode of origin. They are probably sedimentary deposits like the Clinton iron ores, as Sjögren ${ }^{22}$ suggests, but the evidence submitted is not sufficient to eliminate the possibility that they were formed by replacement. Whatever may have been their origin they have passed through the deep-seated zone.

The ores are classified commercially according to their content of iron. Those that contain less than 48 per cent (average about 35 per cent) are classed as "concentrating" ores; those that contain more than 48 per cent are classed as direct smelting ores.

The larger deposits are found throughout northern Norway, and a group of smaller deposits in the Christiania district produces ore that is used in local smelters.

Concentrating ores of northern Norway. ${ }^{23}$-The concentrating ores are magnetite and hematite disseminated in metamorphic rocks.

In estimating the reserves the large bodies of concentrating ore that can be mined by open cut were classed as "known," and the smaller bodies or the deeper parts of larger bodies were classed as "probable" and "possible" reserves, according to the time at which they might be mined, whether in the near or the more distant future. The figures given are based on estimates made by Vogt ${ }^{24}$ or on more recent private reports.

Iron in concentrating ores of northern Norway.

[Millions of metric tons of iron.]

\begin{tabular}{|c|c|c|c|}
\hline & Known. & Probable. & Possible. \\
\hline \multirow[t]{2}{*}{ 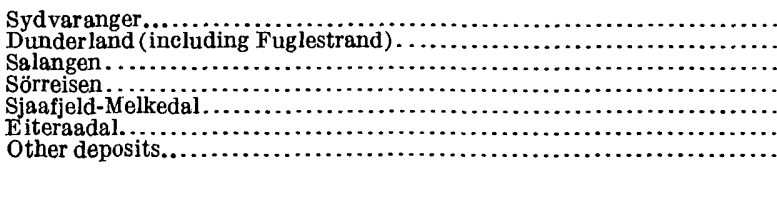 } & $\begin{array}{r}36.0 \\
31.5 \\
7.5\end{array}$ & 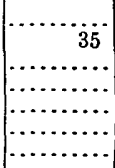 & $\begin{array}{r}135.0 \\
105.0 \\
12.0 \\
15.0 \\
6.0 \\
4.5 \\
10.0\end{array}$ \\
\hline & 75 & 35 & 287.5 \\
\hline
\end{tabular}

The "other deposits" include those at Tromsösund, Öksfjord on Hindö, Bogen-i-Ofoten, and Näverhaugen.

${ }^{22}$ Sjögren, H., The geological relations of the Scandinavian iron ores: Am. Inst. Min. Eng. Trans., vol. 38, pp. 766-836, 1907.

s3 Vogt, J. H. L., Die regional-metamorphosierten Eisenerzlager im nördlichen Norwegen: Zeitschr. prakt. Geologie, vol. 11, pp. 24-28, 59-65, 1903.

84 Op. cit. (The iron-ore resources of the world, vol. 2), pp. 603-621. 
Direct smelting ores of northern Norway.-Mineralogically and genetically the direct smelting ores are similar to the concentrating ores but can be smelted without previous beneficiation.

Iron in direct smelting ores of northern Norway.

[Millions of metric tons of iron.]

\begin{tabular}{|c|c|c|c|}
\hline . & Known. & Probable. & Possible. \\
\hline \multirow[t]{2}{*}{ 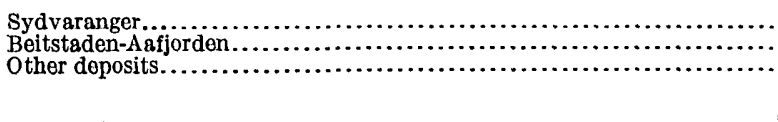 } & $\begin{array}{r}2.1 \\
4.1 \\
.1\end{array}$ & $\begin{array}{r}3.1 \\
8.3 \\
.2\end{array}$ & $\begin{array}{r}4.2 \\
11.0 \\
.4\end{array}$ \\
\hline & 6.3 & 11.6 & 15.6 \\
\hline
\end{tabular}

The location of the important Sydvaranger deposits is shown in figure 25. Among the "other deposits" are those of Melövar and Bjarkö, Kaljord, Lunkenfjord, and smaller deposits on the Lofoten-Vesteraalen islands.

Titaniferous ore.-There are in Norway many small deposits of workable ore that are at present unavailable because they contain from 3 to 40 per cent of titanium dioxide. The largest deposit is at Selvaag, in the Lofoten Islands. The total "possible" reserve of ore of this class amounts to $17,500,000$ metric tons of metallic iron.

"Purple ore."-The deposits of iron and copper sulphides at Sulitjelma produce on roasting, as a by-product, an iron ore which contains 62 per cent

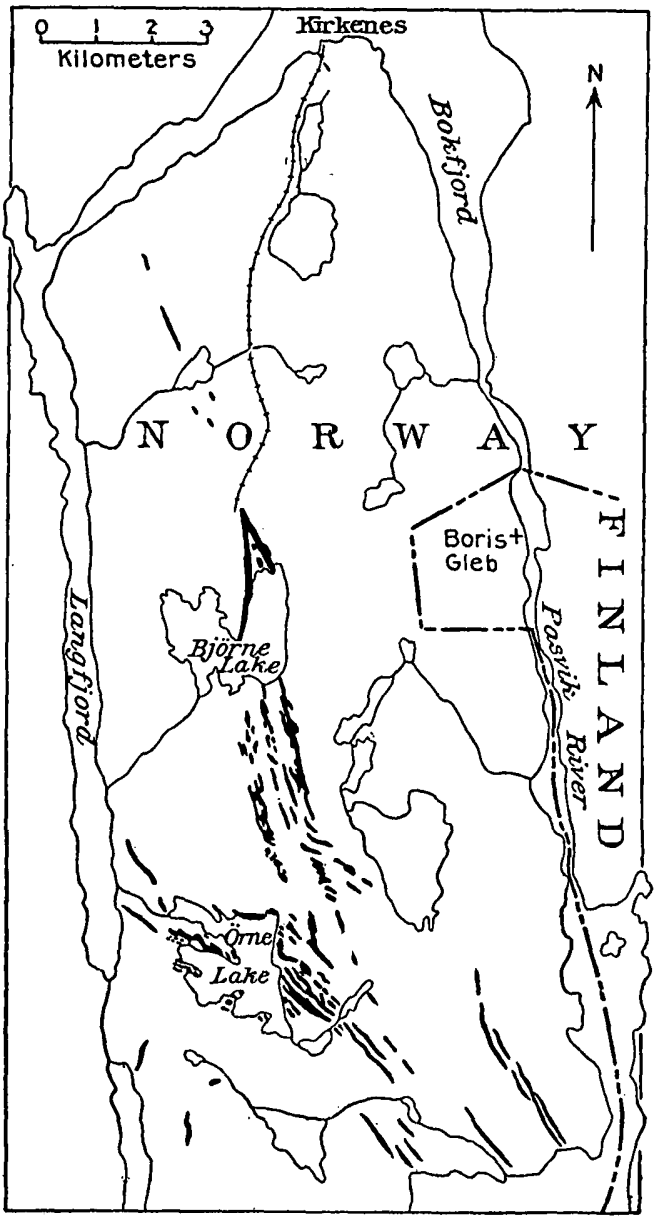

Fraure 25.-Map of iron-ore fields of Sydvaranger, Norway. (After Beyschlag, Krusch, and Vogt, 1910.) of iron and is used in the blast furnace. The iron in these deposits, estimated in metric tons, may be classified as known, 3,100,000; probable, 7,400,000; possible, 6,200,000. 
Southern Norway.-In southern Norway, in the Christiania district at Fehn, Kragerö, Nissedal, and Arendal, there are several small deposits of direct smelting ores. The ore contains about 50 per cent of iron and some phosphorus. The ore minerals are magnetite and hematite. They are contact deposits or replacement lodes and are of igneous origin.

Vogt's figures, which have been used here, show resources in metric tons of metallic iron as follows: Known, 1,400,000; probable, $2,400,000$; possible, $3,300,000$.

Summary for Norway.-Estimates of the quantities of metallic iron in the deposits of iron ore in Norway are given below.

Iron resources of Norway.

[Millions of metric tons of iron. Compare Pl. XII, in pocket.]

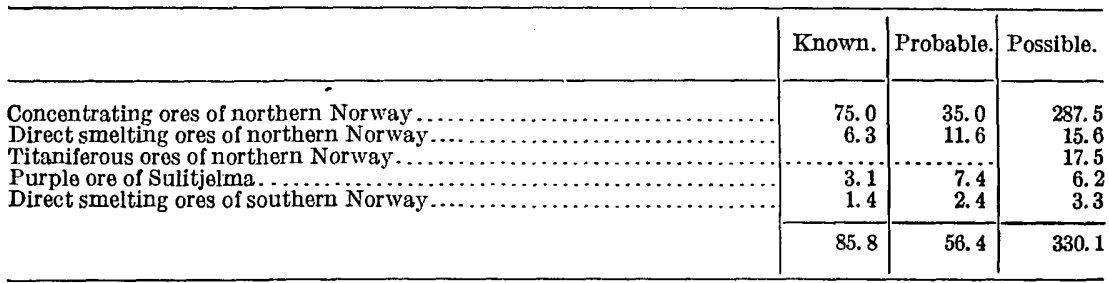

\section{PRODUCTION AND CONSUMPTION.}

Norway exports practically all the iron ore she produces, which amounts to about 0.5 per cent of the total European output. As she lacks coal she can establish an iron industry only by electrometallurgy. Her ores have not been mined to the extent that they appear to warrant, and their future development will probably be rapid.

\section{SWEDEN. ${ }^{25}$}

\section{DISTRIBUTION, CHARACTER, AND EXTENT OF THE DEPOSITS.}

The iron-ore deposits of Sweden lie in three geographic regionsin Swedish Lapland, or northern Sweden; in central Sweden; and at Taberg, in southern Sweden. (See Pl. XII, in pocket.)

${ }_{25}$ Lundbohm, Hjalmar, Petersson, Walfr., and Tegengren, F. R., The iron-ore resources of Sweden: The iron-ore resoutres of the world (11th Internat. Geol. Cong.), vol. 2, pp. 551-603, Stockholm, 1910. Launay, L. de, L'origine et les caractères des gisements de fer scandinaves: Annales des mines, vol. 4, pp. 49-106, 109-211, 1903. Sjögren, H., The geological relations of the Scandinavian iron ores: Am. Inst. Min. Eng. Trans., vol. 38, pp. 766-836, 1907. Guinchard, J., Sweden, 2d ed., 1914. Nordenström, G., The most prominent and characteristic features of Swedish iron mining: Iron and Steel Inst. Jour., 1898, No. 2, pp. 35-76. Spackeler, _-, Schwedens Eisensteinbergbau: Glückauf, vol. 45, pp. 473-481, 509-515, 545-550, 594-603, 632-638, 669-672, 1909. Winchell, H. V., Swodish mines and mining: Min. and Sci. Press, vol. 102, pp. 35-38, 1911. 


\section{NORTHERN SWEDEN. ${ }^{26}$}

The iron ores of Swedish Lapland (see fig. 26) form the largest reserve of magnetite in Europe, probably in the world. They are found in igneous rocks and in metamorphic rocks of igneous origin. The ores occurin lenticularmasses, in dikelike forms, and in bands that alternate with bands of apatite rocks from which they may be easily separated. They are associated with syenitic rocks.

The genesis of the ores has been a subject of discussion among geologists for many years. It has been described as sedimentary metamorphic by Herdsman ${ }^{27}$ as pneumatolytic hydrothermal by Bäckström, ${ }^{28}$ and as magmatic by Högbom, ${ }^{29}$ whose view has been supported and enlarged upon by many others. The bulk of the evidence points clearly to their

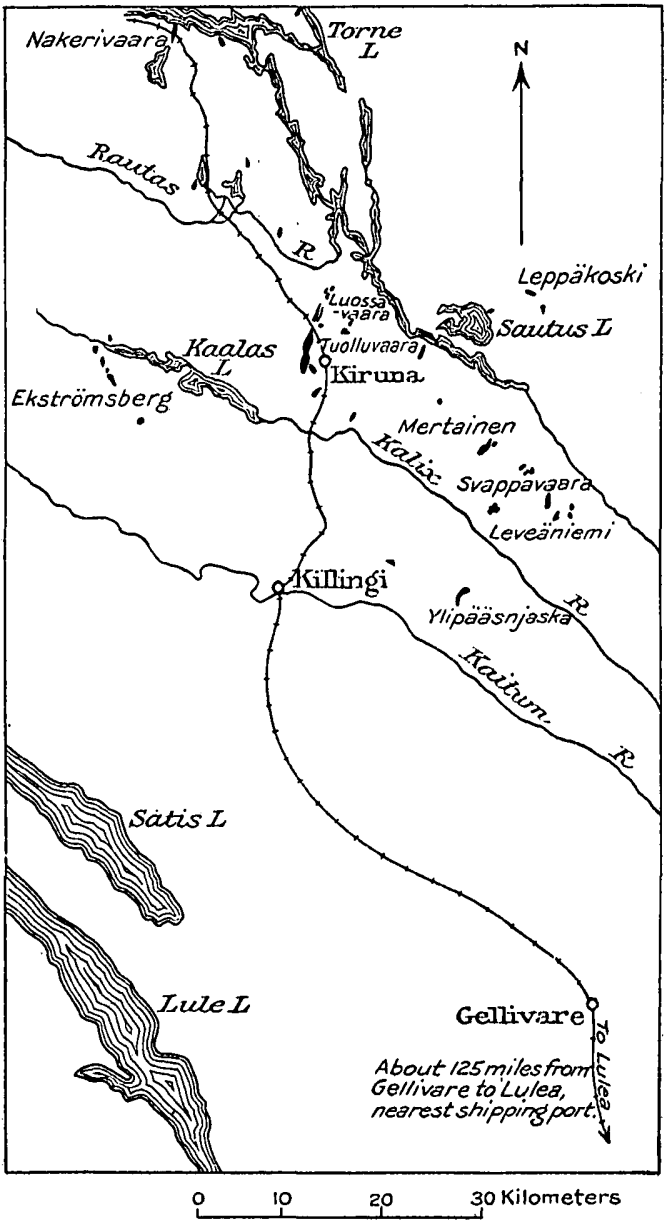
magmatic origin. The Figure 26.-Sketch map showing distribution of iron-ore deposits presence of some tourof northern Swoden. (After E. C. Eckel, 1914.)

maline, of specularite, and of apatite indicates that the ore is a segregation of the pegmatitic rather than of the basic type.

20 Daly, R. A., Origin of the iron ores at Kiruna, Stockholm, 1915. Fermor, L. I.., On the origin of the iron ores of Swedish Lapland: Iron and Steel Inst. Jour., 1911, No. 2, pp. 113-122. Ceijer, P., Igncous rocks and iron ores of Kirunavaara, Luossavaara, and Tuollavaara, Stockholm, 1910. Geljer, P., Studies on the geology of the iron ores of T.apland: Geol. Fören. Stockholm Förh., 1912.

${ }^{27}$ Herdsman, W. H., On the organic origin of the sedimentary ores of iron and of their metamorphosed forms, the phosphoric magnetites: Iron and Steel Inst. Jour., 1911, No. 1, p. 476.

${ }_{28}$ Lundbohm, H., Sketch of the geology of the Kiruna district: Cong. geol. intarnat., 11e sess., Guide des excursions, No. $5,1910$.

${ }^{99}$ Högbom, quoted by Stutzer, O., The geology and origin of the Lapland ores: Irgn and Steel Inst, Jour., 1907, No. 2, p. 141, 
O. Stutzer, ${ }^{30}$ in a very able thesis, maintains that the ore and apatite and the associated syenitic rocks are intrusive. Geijer ${ }^{31}$ maintained until recently that they are extrusive, but in his latest article $^{32}$ on the subject he records more recent observations that have caused him to alter his opinion and to agree that the ores are intrusive.

Metamorphism has been an agent in the formation of most of the deposits, especially at Gellivare, where its effects are more clearly evident.

The ore is of high grade, containing 62 per cent of iron, and the greater part of it contains from 1 to 2 per cent of phosphorus. The ore at Luossavaara, Leveäniemi, and Mertainen contains less phosphorus. That at Ruoutevare contains so much titanium that it is considered as only a "possible" reserve.

Iron resources of northern Sweden.

[Millions of metric tons.]

\begin{tabular}{|c|c|c|c|c|c|c|}
\hline & \multicolumn{2}{|c|}{ Known. } & \multicolumn{2}{|c|}{ Probable. } & \multicolumn{2}{|c|}{ Possible. } \\
\hline & Ore. & Iron. & Ore. & Tron. & Ore. & Iron. \\
\hline \multirow[t]{2}{*}{ 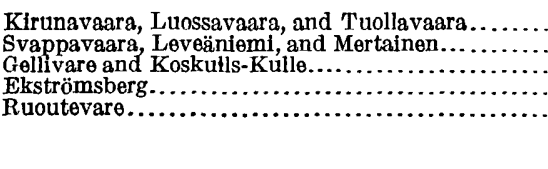 } & $\begin{array}{r}365 \\
50 \\
129 \\
20\end{array}$ & $\begin{array}{r}226.3 \\
31.1 \\
82.7 \\
12.8\end{array}$ & $\begin{array}{r}420.0 \\
35.8 \\
127.5 \\
20.0\end{array}$ & $\begin{array}{r}260.4 \\
21.3 \\
81.6 \\
12.8\end{array}$ & $\begin{array}{r}840.0 \\
61.7 \\
115.7 \\
40.0 \\
12.0\end{array}$ & $\begin{array}{r}520.8 \\
35.8 \\
74.0 \\
25.2 \\
4.8\end{array}$ \\
\hline & 564 & 352.9 & 603.3 & 376.1 & $1,069.4$ & 660.6 \\
\hline
\end{tabular}

CENTRAL SWEDEN. ${ }^{33}$

The ores of central Sweden occur as lenses and stocks of magnetite in schists and gneisses. Their geology is complex. They are probably ores of magmatic derivation, like those of northern Sweden, but have migrated farther from the parent magma and have undergone greater metamorphism.

A map in the atlas of "The iron-ore resources of the world" 34 shows 66 deposits in Sweden, of which that at Grängesberg, the largest, is shown in detail in the accompanying map (fig. 27). Swedish statistics include still others that are not shown on the map.

\footnotetext{
${ }^{30}$ Stutzer, O., Die Eisenerzlagerstätten "Gellivare" in Nordschweden: Zeitschr. prakt. Geologie, vol. 14, pp. 137-140, 1906. Stutzer, O., Die Eisenerzlagerstätten bei Kiruna: Zeitschr. prakt. Geologie, vol. 14, pp. 65-71, 140-142, 1906. Stutzer, O., The geology and origin of the Lapland iron ores: Iron and Steel Inst. Jour., 1907, No. 2, pp. 106-207.

81 Geijer, P., Igneous rocks and iron ores of Kirunavaara, Luossavaara, and Tuollavaara, Stockholm, 1910.

${ }^{82}$ Geiger, P., Recent developments at Kiruna: Sveriges geol. Undersökning Årsbok 12, pt. 5, 1918.

s8 Johansson, H. E., The Grängesberg iron ores: Cong. géol. internat., 11 ${ }^{\mathrm{e}}$ sess., Guide des excursions, No. 32, 1910. Kukuk, —, Die mittelschwedischen Erzlagerstätten; Glückauf, vol. 47, pt. 1, pp. 820-827, 861-870, 905-914, 1911. Petersson, W., Die Erzfelder von Norberg: Cong. geol. internat., 11 ० sess., Guide des excursions, No. 29, 1910. Sjögren, H., The Persberg mining field: Idem, No. 34. Sjögren, H., The Längban mining field: Idem, No. 33.

31 Tegengren, F. R., [The iron-ore resources of] central and southern Sweden: The iron-ore resources of the world (11th Internat. Geol. Cong.), pp. 586-597, Stockholm, 1910.
} 


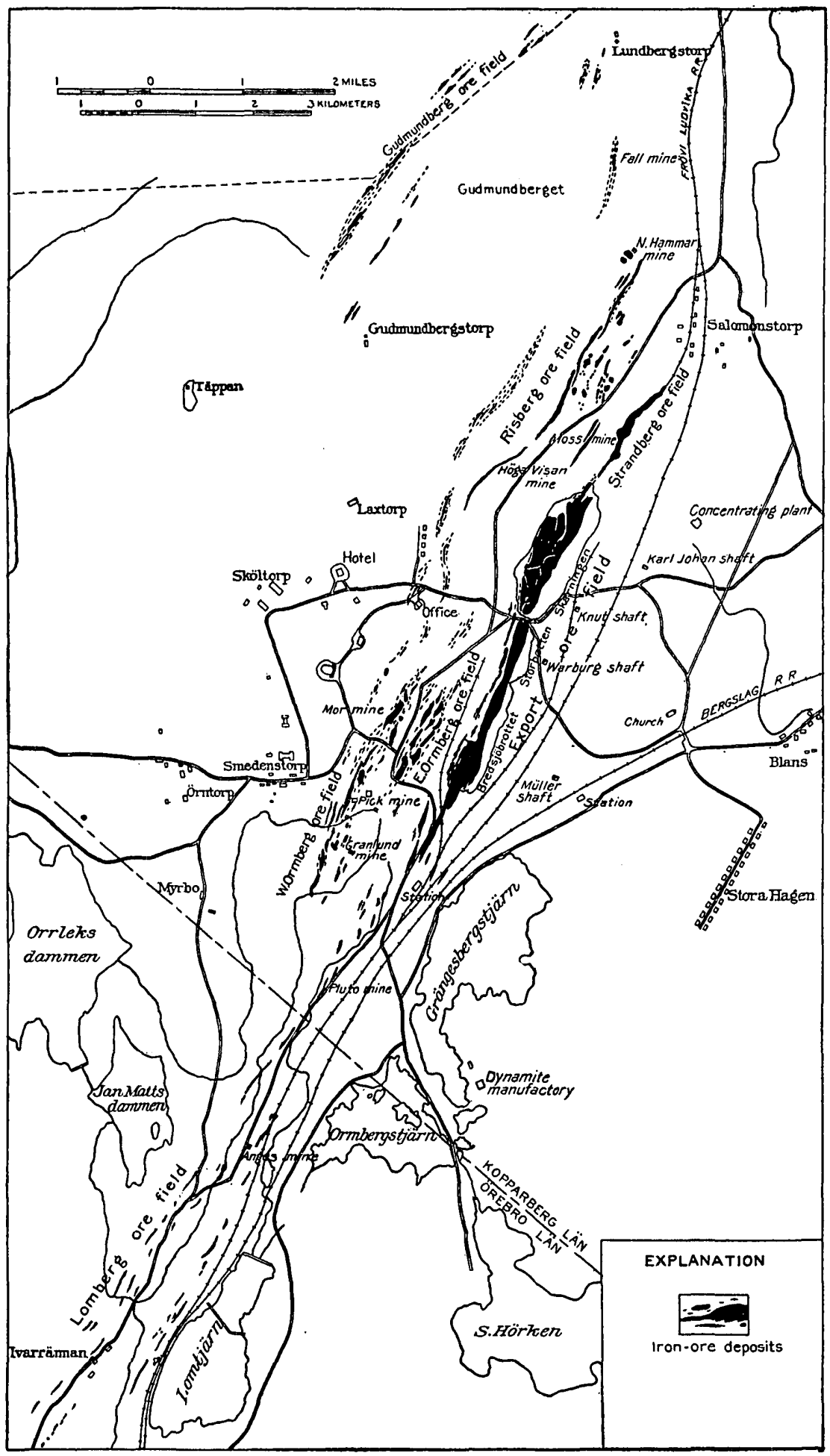

Frgure 27. $\rightarrow$ Map of the iron-ore field at Grängesberg, central Sweden. (From "The iron-ore resources $15945^{\circ}-21-$ Bull. 706 of the world.") 
The ore in the largest deposits contains much phosphorus, but that in many of the smaller deposits contains less. About one-third of the ore is concentrating ore and about two-thirds is direct smelting ore.

From figures given by Tegengren (185,000,000 tons) and from the official statistics of the production in 1916 the iron content of these deposits has been figured as 90,000,000 tons "known." As there are many undeveloped bodies, and as certain producing areas were not considered by Tegengren, 60,000,000 tons more may be classed as "possible."

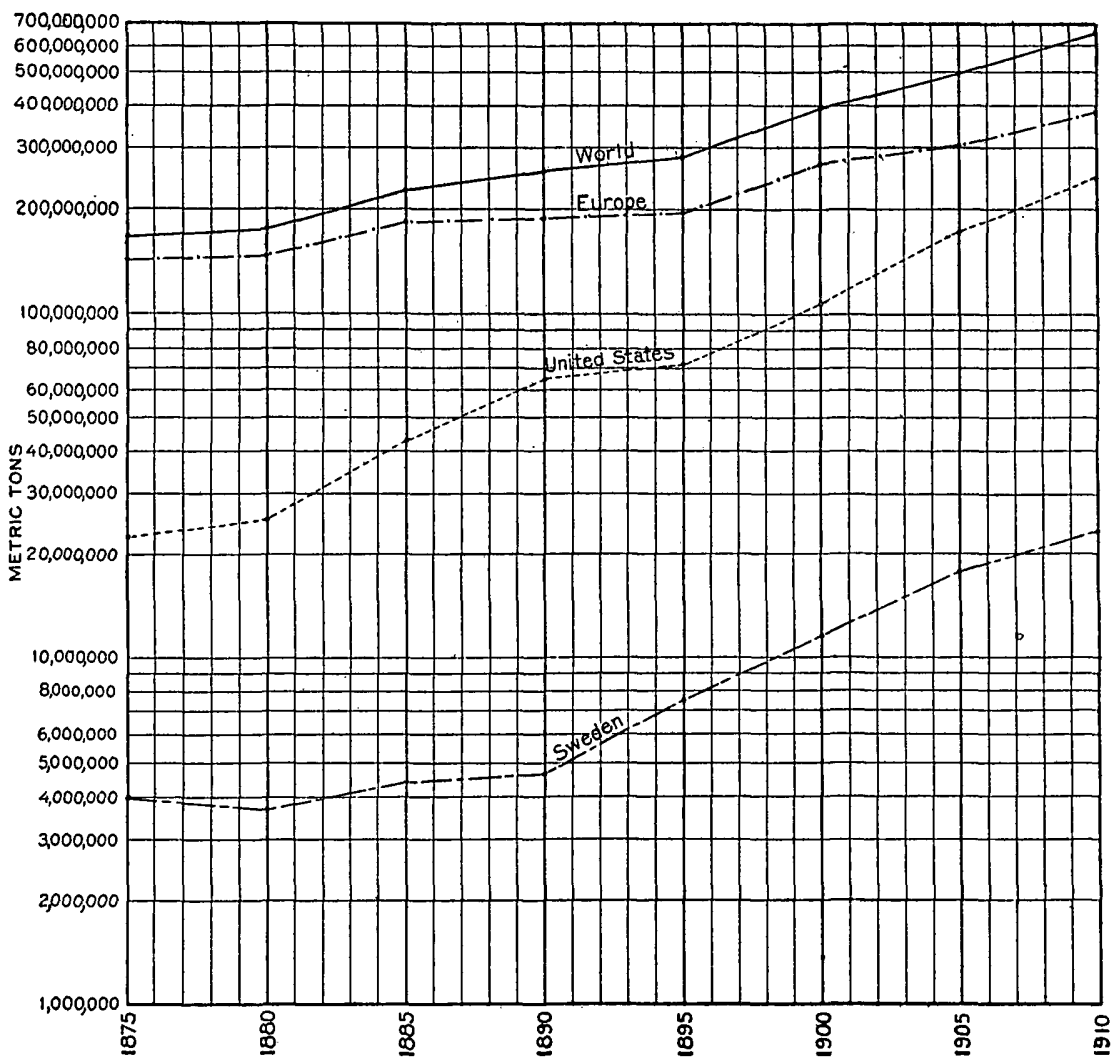

Figure 28.-Ratio chart showing iron ore produced during five-year periods ending 1875 to 1910 in Sweden, Europe, the United States, and the world. (See explanation-of fig. 8, p. 41.)

\section{SOUTHERN SWEDEN.}

In southern Sweden, at Taberg, there is a deposit of concentrating ore of titaniferous magnetite, which is made up of segregated masses of the basic type. Owing to its content of titanium it is not now available, so it is put down as a "possible" reserve containing $50,000,000$ metric tons of ore carrying $9,000,000$ metric tons of iron. 
SUMMARY FOR SWEDEN.

The metallic iron in the iron-ore deposits of Sweden is estimated in the table below.

Iron resources of Sweden.

[Millions of metric tons of iron. Compare Pl. XII, in pocket.]

\begin{tabular}{|c|c|c|c|}
\hline & Known. & Probable. & Possible. \\
\hline \multirow[t]{2}{*}{ 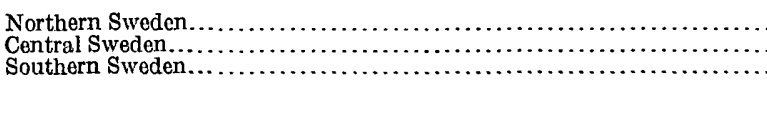 } & $\begin{array}{r}352.9 \\
90.0\end{array}$ & $\begin{array}{r}376.1 \\
\cdots \cdots \cdots \cdots \\
\cdots \cdots \cdots \cdots \\
\end{array}$ & $\begin{array}{r}660.6 \\
60.0 \\
9.0 \\
\end{array}$ \\
\hline & 442.9 & 376.1 & 729.6 \\
\hline
\end{tabular}

PRODUCTION AND CONSUMPTION.

As shown in the accompanying ratio chart (fig. 28), Sweden has had a steadily increasing production of iron ore. Her production of pig iron also has been increasing, but at a slower rate, though in recent years the introduction of electrometallurgy has accelerated the rate considerably. In 1913 Sweden produced 7 per cent of the iron ore mined in Europe and consumed only 1 per cent of it. With her very great reserves she should be an exporter, for she has much more ore than she needs for domestic use. Through her control of the railroads Sweden has strictly regulated the exportation of iron ores. She has set a definite schedule of the amount of ore which may be exported each year and will doubtless make the mining companies abide by it. This control is designed to conserve a natural resource that can be used in exchange for coal she requires from Great Britain and Germany.

\section{FINLAND.}

\section{DISTRIBUTION, CHARACTER, AND EXTENT OF THE DEPOSITS.}

The greater part of Finland is a massif of ancient crystalline rocks covered with glacial débris. At the extreme north end of the country and on its southwestern fringes there are some early Paleozoic formations. The Finnish territory is physiographically a part of the Scandinavian massif, and the history of the primary iron ores of Finland is the same as the history of those of Norway and Sweden. ${ }^{35}$ (See Pl. XIII, in pocket.)

In northern Finland, near Kittilä, ${ }^{36}$ there are large deposits of concentrating iron ore in metamorphic rocks. The mineral is magnetite. The ore generally contains little iron, but in some of the deposits, such as those at Sydvaranger, there are pockets of ore of

${ }^{85}$ [Finland's economic ore deposits, as taken from consular reports]: Zeitschr. prakt. Geologic, vol. 15, pp. 294-302, 1907. Trustedt, O., Die Eisenerzvorräte Finnlands: The iron-oro resources of the world (11th Internat. Geol. Cong.), vol. 1, pp. 547-551, Stockholm, 1910.

${ }^{36} \mathrm{Keene}, \mathrm{A}$. F., unpublished information. 
better grade. Two bands, 300 to 500 meters wide, have been traced for 12 kilometers. Though they are 180 kilometers from the nearest railroad the properties at Kittilä are said to have been sold for $15,000,000$ kroner (about $\$ 4,000,000$ ).

The only statement available ${ }^{37}$ as to the extent of the deposits says there are "exhaustless quantities" of ore, a statement which obviously affords no ground for an estimate.

In central Finland, in the "lake country," are the so-called "lake ores," which are brown bog ores containing 35 per cent of iron and generally considerable phosphorus.

Here also reliable estimates are lacking, though the deposits appear to be extensive.

In southern Finland, at Jussarö ${ }^{38}$ on the Gulf of Finland, and at Pitkäranta, ${ }^{39}$ near Lake Ladoga, there are ore bodies of the igneous type. Those at Jussarö are lenses of magnetite, which pitch under the Gulf of Finland and have been explored by magnetic surveys. At Pitkäranta the ore is probably of contact-metamorphic type and consists of magnetite of concentrating grade. The ore contains 1.3 per cent of sulphur.

Iron resources of Finland.

[Millions of metric tons.]

\begin{tabular}{|c|c|c|c|c|c|c|}
\hline & \multicolumn{2}{|c|}{ Known. } & \multicolumn{2}{|c|}{ Probable. } & \multicolumn{2}{|c|}{ Possible. } \\
\hline & Ore. & Iron. & Ore. & Iron. & Ore. & Iron. \\
\hline \multirow[t]{2}{*}{$\begin{array}{l}\text { Jussarö...... } \\
\text { Pitkäranta.. }\end{array}$} & 13.5 & 3.6 & 30 & $\begin{array}{c}11.4 \\
\cdots \cdots\end{array}$ & $\ddot{7}$ & 1.9 \\
\hline & 13.5 & 3.6 & 30 & 11.4 & 7 & 1.9 \\
\hline
\end{tabular}

Because of lack of information probably only a very small part of Finland's iron ore has been estimated. More ore bodies of the Kittilä type may perhaps be discovered in northern Finland by further prospecting, for the country is similar to that of northern Norway, in which such ores are so generally distributed.

\section{PRODUCTION AND CONSUMPTION.}

The lake ores have heretofore been utilized for a local industry and the primary ores of the north may be exploited hereafter, but as Finland lacks coal there is no reason to suppose that she will ever develop an extensive iron industry.

\footnotetext{
${ }^{37}$ Min. Jour. (London), vol. 87, pp. 375-376, 1909.

${ }^{38}$ Tiegerstedt, A. F., Fennia [Finnish Geog. Soc. Bull.], vol. 14, No. 8, 19 pp., 1898.

${ }^{89}$ Trustedt, O., Die Erzlagerstätten von Pitkäranta am Ladoga-See: Comm. Geol. de Finlande Bull. $19,1907$.
} 


\section{THE BALTIC STATES.}

Esthonia, Latvia, and Lithuania are composed of low, flat-lying ground, which lies within an area that was once covered by glaciers. No deposits of iron ores have been reported from them, and it seems as if the only deposits they are likely to contain would be surficial bog ores of small extent.

\section{POLAND. ${ }^{40}$}

\section{DISTRIBUTION, CHARACTER; AND EXTENT OF THE DEPOSITS.}

Location of mineral lands.-New Poland (see Pl. XIII, in pocket) covers territory whose geologic structure ranges from that of the flat-lying young formations of the northern plains and marshes through that of the gently folded Mesozoic and Paleozoic rocks of central and southern Russian Poland to the mountain structure of the Karpathians. Poland's most valuable mineral resources lie in the Dombrova coal basin and the Triassic lead and zinc basin in its southwestern part. Next in value are the iron ores in the Mesozoic and Paleozoic rocks of Russian Poland. The mountainous regions of the northern slopes of the Karpathians are singularly lacking in mineral wealth, probably because the Tertiary rocks of which these slopes are composed were deposited under conditions that were adverse to the formation of sedimentary mineral deposits and because no later intrusions have introduced metalliferous solutions.

The eastern limits of new Poland have not been definitely fixed, but as no important iron ores are reported from the doubtful areas their determination does not affect the total reserve.

Triassic ores. ${ }^{41}$-In southwestern Poland lies the Triassic (Muschelkalk) basin, which is mostly in Silesia and partly in Russian Poland and Galicia. The iron ores are gossans that overlie the zino and lead ores, to which this area owes much of its value.

Jurassic and bog ores. ${ }^{42}$-Directly northwest of the Triassic area, in Jurassic sediments, there are sedimentary spathic ores with brown ore, derived from them. These ores average between 30 and 35 per cent of iron and have furnished a considerable supply to local furnaces. Toward the northeast, in the Kielce district, ${ }^{43}$ ores of the same sort at the same and lower horizons are found.

\footnotetext{
10 Iron-oro resources of the world (11th Internat. Geol. Cong.), vol. 1, pp. 173-174, 494-501, Stockholm, 1910.

4 Bartonec, F., Über die erzführenden Triasschichten Westgaliziens: Oesterr. Zeitschr. Berg- u. Hüttenwesen, vol. 50, pp. 645-650, 664-669, 1906. Tietze, E., Die geognostischen Verhältnisse der Gegend von Krakau: K.-k. geol. Reichsanstalt Jahrb., vol. 37, p. 423, 1887.

6 Bartonec, F., UUber die geologisch-montanistischen Verhältnisso des südöstlichen Teiles von Polen: Oesterr. Zeitschr. Berg- u. Hüttenwesen, vol. 62, pp. 726-729, 1914.

43 Doborzynski, S., [Iron ore in the Kielce district]: Creol. Centralblatt, vcl. 2, pp. 262, 686, 1902.
} 
In the estimates given below the gossan ores have been left out of account.

Jurassic iron ores of Poland.

[Millions of metric tons.]

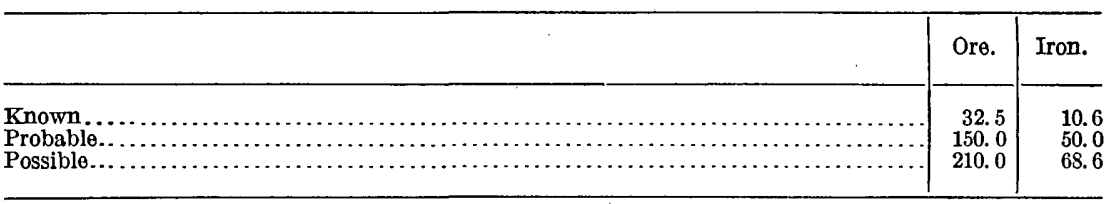

Besides the Jurassic ores Poland will be able to count on some of the bog ores that formerly belonged to Germany. The amount has been taken arbitrarily as one-fifth of the former German supply.

Bog iron ores of Poland.

[Millions of metric tons.]

\begin{tabular}{|c|c|c|}
\hline & Ore. & Iron. \\
\hline 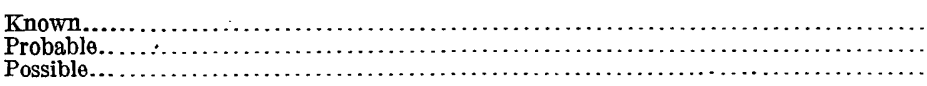 & $\begin{array}{l}2 \\
2 \\
2\end{array}$ & $\begin{array}{r}0.6 \\
.6 \\
.0\end{array}$ \\
\hline
\end{tabular}

Iron resources of Poland.

[Millions of metric tons of iron.]

\begin{tabular}{|c|c|c|c|}
\hline & Known. & Probable. & Possible. \\
\hline \multirow[t]{2}{*}{ 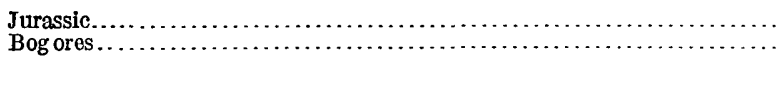 } & $\begin{array}{r}10.6 \\
.6\end{array}$ & $\begin{array}{r}50.0 \\
.6\end{array}$ & $\begin{array}{r}68.6 \\
.6\end{array}$ \\
\hline & 11.2 & 50.6 & 69.2 \\
\hline
\end{tabular}

\section{PRODUCTION AND CONSUMPTION.}

In 1913 Russian Poland produced a little over 300,000 tons of iron ore. The territory added to it from Germany and Austria to form new Poland has added a little to the productive capacity of new Poland, but none of the iron deposits are far from the line that lies between economic availability and worthlessness. Slight economic changes might easily make it wiser for Poland to draw her iron ore from foreign sources rather than to mine her own ore.

\section{AUSTRIA.}

\section{DISTRIBUTION, CHARACTER, AND EXTENT OF THE DEPOSITS.}

The new Austria (see Pl. XIV, in pocket) lies in the eastern Alpine ranges and except a small northern part is entirely mountainous. As might be expected in such an area there are numerous small deposits of iron ore, but the only large deposits are the Erzberg of Styria and the Hüttenberg of Carinthia.

The Styrian Erzberg is world famous for the excellent quality of the iron ore mined there and has supplied iron since the earliest 
historical times. The location of the main deposits is shown in figure 29. The ores in both the Styrian district and in the Hüttenberg district of Carinthia appear to be siderite and brown ores resulting from its decomposition. According to most recent reports, ${ }^{44}$ the carbonate has been formed as metasomatic replacement of Devonian and older limestones. The older reports regard the deposits as syngenetic-that is, as formed by sedimentation at the time the inclosing rocks were formed.

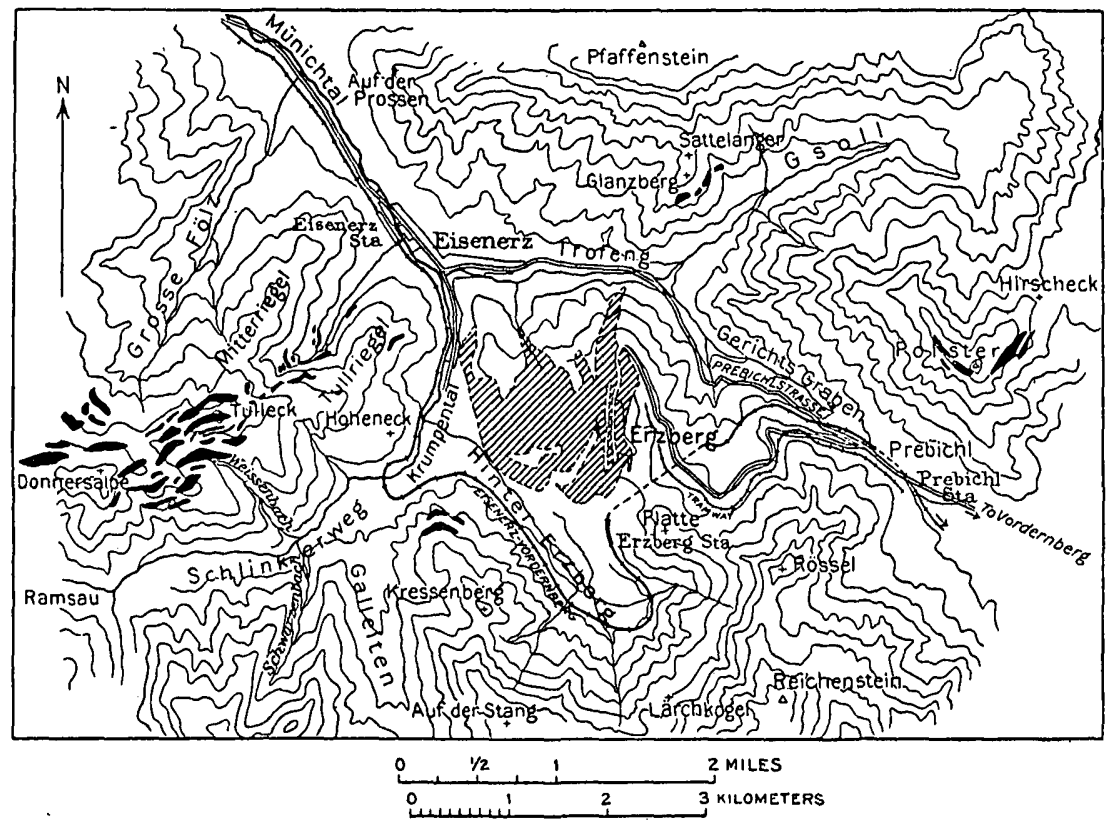

Figure 29.-Map showing deposits of iron ore in the vicinity of Erzberg, Styria, Austria. (From "The iron-ore resources of the world.")

The ores are of rather low grade, but simple roasting gives a product containing 50 per cent of iron. They are very desirable because of their freedom from sulphur and phosphorus.

In the estimate of reserves given below about half of the low-grade, "rohwand" ores, as they are called, were classified as "possible."

Iron resources of Austria.

[Millions of metric tons.]

\begin{tabular}{|c|c|c|c|c|c|c|}
\hline & \multicolumn{2}{|c|}{ Known. } & \multicolumn{2}{|c|}{ Probable. } & \multicolumn{2}{|c|}{ Possible. } \\
\hline & Ore. & Iron. & Ore. & Iron. & Oro. & Jron. \\
\hline \multirow[t]{2}{*}{ 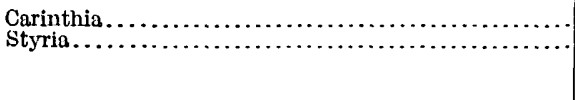 } & $\begin{array}{r}7.0 \\
210.0\end{array}$ & $\begin{array}{r}3.2 \\
73.5\end{array}$ & $\begin{array}{r}7.0 \\
18.0\end{array}$ & $\begin{array}{l}3.2 \\
6.3\end{array}$ & 150.0 & 300 \\
\hline & 217. 0 & 76.7 & 25.0 & 9.5 & 150.0 & 30.0 \\
\hline
\end{tabular}

44 Launay, L. de, Gîtes minêraux et mótallifères, vol. 2, pp. 396-399, Paris, Ch. Bêranger, 1913. 


\section{PRODUCTION AND CONSUMPTION.}

In 1913 the production of iron ore in what is now the Austrian Republic amounted to about 2,000,000 tons. Most of the ore was utilized in domestic furnaces. Hereafter Austria will be largely dependent on foreign sources for fuel. Formerly she shipped much of her ore to Trieste and imported coal from England for smelting it. Now that she has access to the sea only through foreign territory she may find it better to import coal from Silesia. The Austrian iron ores are so desirable that there will always be a demand for them and some way will be found to utilize them.

\section{CZECHO-SLOVAKIA.}

\section{DISTRIBUTION, CHARACTER, AND EXTENT OF THE DEPOSITS.}

Czecho-Sovakia is fortunate in containing within her borders all the essentials for a successful iron industry. It is a large, level, interior country, fit for agriculture, bordered by mountains, and cut by northeastward-trending ranges that contain an abundance of iron and corl. (See Pl. XIV, in pocket.)

\section{BOHEMIA.}

The location of the numerous Bohemian iron-ore deposits is shown in Plate XV, which is a generalized reproduction of map 12 of the atlas accompanying the volume on the iron resources of the world issued by the Eleventh International Geological Congress. The most extensive and productive area of iron-ore deposits lies in central Bohemia, in the Brda Mountains, where beds of oolitic hematite and of the iron silicate chamosite are intercalated in Silurian sediments. The ores are of low grade, containing an average of about 35 per cent of iron, 13 per cent of silica, and 1.5 to 2 per cent of phosphorus.

The estimate of these ores given by Uhlig ${ }^{45}$ is very comprehensive. The known ore, $35,000,000$ tons, can be considered as averaging 35 per cent of iron and so credited with 12,400,000 metric tons of metallic iron. The "probable" ore, which is estimated on geologic data, amounts to $222,000,000$ tons. In order to allow for a possible decrease in the grade of ores with increase in depth this can be taken as containing 30 per cent of iron and credited with $66,600,000$ metric tons of iron. There remain about 70,000,000 metric tons of undeveloped ores in the possession of companies other than the one making the report. In consideration of the large area occupied by outcrops of these ores the estimate seems low, and for that reason the "pos-

${ }^{45}$ Uhlig, V., Die Eisenerzvorrïte Oesterreichs: The iron-ore resources of the world (11th Internat. Geol. Cong.), vol. 1, pp. 151-153, Stockholm, 1910. 


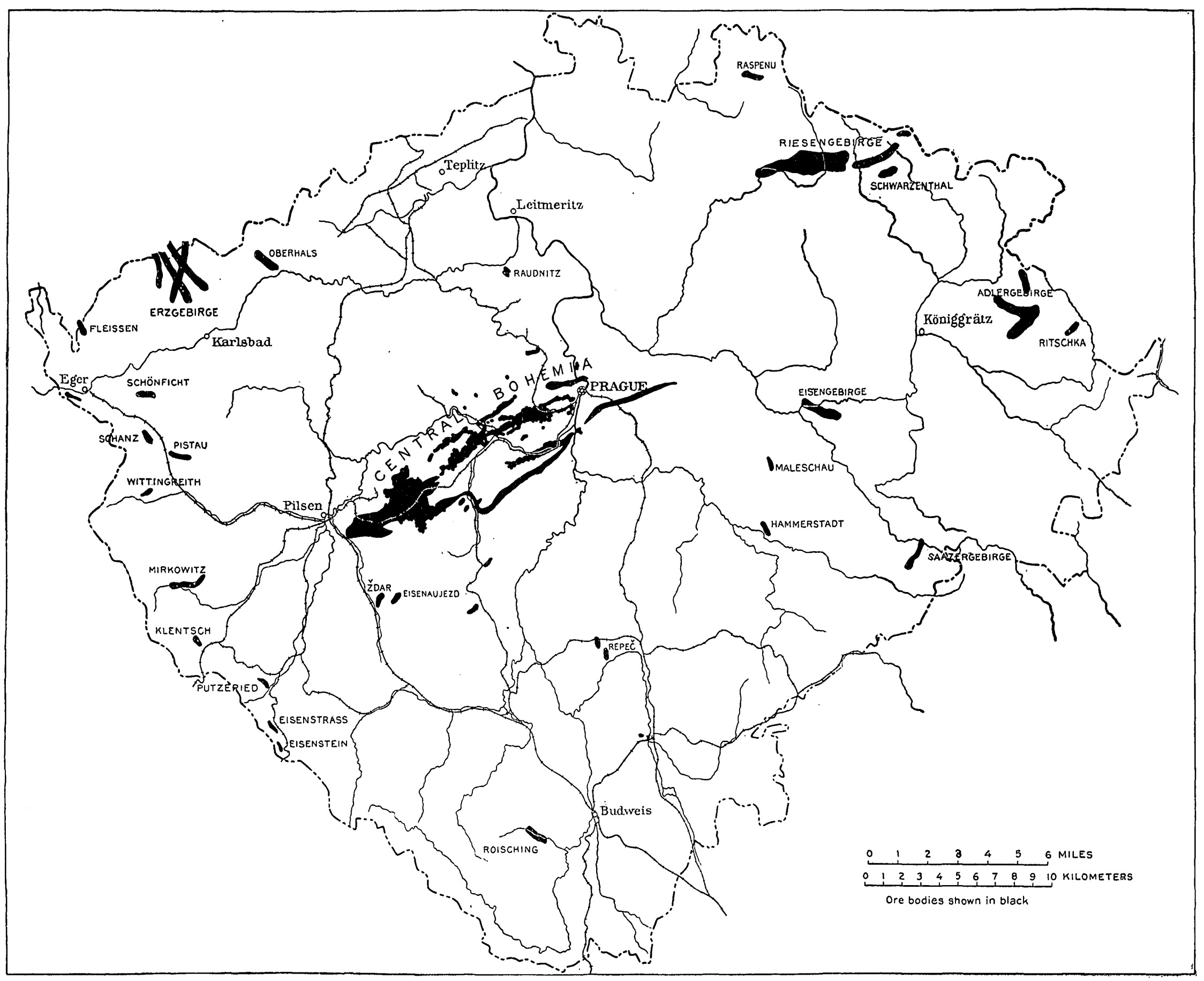

MAP OF BOHEMIA SHOWING DISTRIBUTION OF THE PRINGIPAL IRON-ORE DEPOSITS. 
sible" ore is given as $100,000,000$ metric tons containing $30,000,000$ metric tons of iron.

The numerous small deposits of iron ore in Bohemia, consisting of brown ores, hematite, and magnetite, have been described in concise tabular form by Uhlig. ${ }^{48}$ None of these deposits have produced ore recently and no statement as to their content of ore or of iron is available, but they form a possible reserve that can not be entirely neglected. They are credited in the "possible" class with 25,000,000 metric tons of iron.

Iron resources of Bohemia.

[Millions of metric tons of iron.]

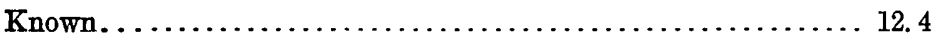

Probable......................................66.6

Possible...................................... 55.0

The iron ores of Moravia have been described and estimated by Kretschmer. ${ }^{47}$ The larger deposits lie in the March Valley and in the foothills of the Sudetic Mountains. Those in the valley consist of bedded ores in Devonian rocks; those in the foothills are mostly pre-Cambrian magnetites and brown ores derived from them and from amphibolite rocks that accompany them.

The entire Moravian reserve of iron amounts to less than 5 per cent of the world's production of pig iron in 1913. As Moravia has become a part of Czecho-Slovakia its iron reserve will be merely a small addition to the Bohemian reserves. But Moravia contains some of the richest coking coal of the Dombrova Basin, and though its production of iron ore in 1912 amounted to only 6,268 tons, it produced in that year 507,653 tons of pig iron.

\section{RUTHENIA.}

The iron-ore deposits in Ruthenia were of considerable importance before the war, as they contributed a large supply to the Moravian and Silesian furnaces. The most productive district is that of Szepes-Gömör, ${ }^{48}$ on the southern slope of the Karpathians, whose location is shown in figure 30 . The ore consists of veins and masses

40 Uhlig, V., Die Eisenerzvorräte Oesterreichs, Eisenerzvorkommen Böhmens: The iron-ore resources of the world (11th Internat. Geol. Cong.), vol. 1, pp. 145-149, Stockholm, 1910.

${ }^{7}$ Kretschmer, Franz, Die Erzvorräte der wichtigsten Eisenerzlagerstätten Mährens: Tho iron-ore rosources of the world (11th Internat. Geol. Cong.), vol. 1, pp. 161-171, Stockholm, 1910. Kretschmer, F., Die Sinterbildung vom Eisenerzbergbau Quittein nächst Müglitz (Müihren): K.-k. geol. Reichsanstalt. Jahrb., vol. 52, pp. 353-494, 1902.

48 Loczy, Ludwig von, and Papp, Karl von, Die im ungarıschen Staatsgebiete vorhandenen Eisenerzvorräte: The iron-ore resources of the world (11th Internat. Geol. Cong.), vol. 1, pp. 178-223, Stockholm, 1910. 
of spathic iron ore in a complex series of metamorphic rocks. A small part of the ore mined comes from brown ores derived from the primary carbonates. The ores are genetically connected with intrusions of quartz porphyry.

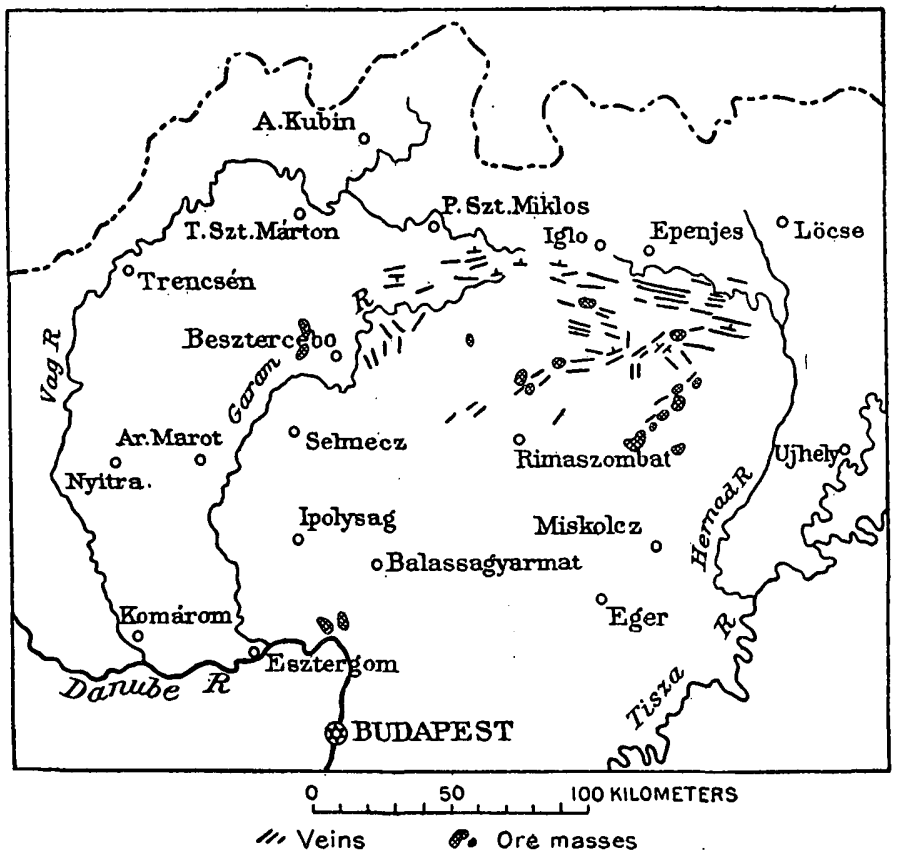

FIGURE 3n.-Map showing deposits of iron ore in the Szepes-Gömör district, Ruthenia, Czecho-Slovakia. (From "The iron-ore resources of the world.")

According to an estimate made by Von Papp $^{49}$ the ores can be tabulated as indicated below.

Iron resources of Ruthenia.

[Millions of metric tons of ore.]

Known.......................................... 26. 1

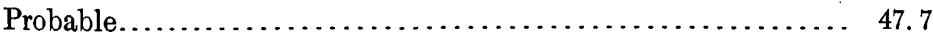

Possible....................................... 18.0

Of this ore the "known" and "probable" averages about 38 per cent and the "possible" is ore of lower grade, which for safety can be reckoned as containing 20 per cent of iron. In terms of metallic iron the "known" reserves are 9,900,000 metric tons, and the "probable" reserves are 18,200,000 metric tons.

The ore contains little phosphorus, and roasting increases its iron content to about 53 per cent and makes it commercially desirable.

9 Papp, Karl von, op. cit., p. 223. 
SUMMARY OF CZECHO-SLOVAK RESERVES.

The metallic content of the iron ores in Czecho-Slovakia is shown in the table below.

Iron resources of Czecho-Slovakia.

[Millions of metric tons of iron.]

\begin{tabular}{|c|c|c|c|}
\hline & Known. & $\begin{array}{l}\text { Prob- } \\
\text { able. }\end{array}$ & Possible. \\
\hline \multirow[t]{2}{*}{$\begin{array}{l}\text { Bohemia... } \\
\text { Ruthenia.. }\end{array}$} & $\begin{array}{r}12.4 \\
9.9\end{array}$ & $\begin{array}{l}66.6 \\
18.2\end{array}$ & $\begin{array}{r}55.0 \\
3.6\end{array}$ \\
\hline & 22.3 & 84.8 & 58.6 \\
\hline
\end{tabular}

PRODUCTION AND CONSUMPTION.

In 1913 Czecho-Slovak territory produced about 2,500,000 metric tons of iron ore. With her large coal resources, of which the best coking coals of the Dombrova Basin are a part, she should be able to utilize her own resources to the fullest extent, together with so much of the Swedish magnetite ores as are necessary for making a good smelting mixture with the central Bohemian ores. The future of the iron industry in Czecho-Slovakia is very promising.

\section{HUNGARY.}

The old Hungary was rich in iron ores. The loss of the SzepesGömör, Banat, and Hunyad districts leaves the new Hungary without any deposits except a few small scattered ones on the Karpathian slopes. Coal is also lacking within the new State, so that there is no reason to expect a Hungarian iron industry.

\section{PRODUCTION AND CONSUMPTION IN THE AUSTRO- HUNGARIAN EMPIRE.}

Though Austria-Hungary has ceased to exist, a brief résumé of her position in 1913 is necessary in the study of Europe as a whole. The resources over which the old empire had control are shown in the following table:

Iron resources of the Austro-Hungarian Empire.

[Millions of metric tons of iron. Compare PI. XIV, in pocket.]

\begin{tabular}{|c|c|c|c|c|}
\hline & Known. & $\begin{array}{l}\text { Prob- } \\
\text { able. }\end{array}$ & Possible. & Type of ore predomtnating. \\
\hline \multirow[t]{2}{*}{ 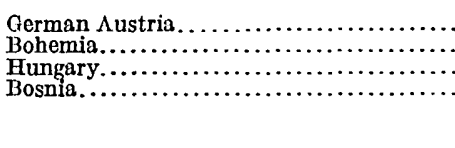 } & $\begin{array}{r}76.7 \\
12.4 \\
12.4 \\
9.5\end{array}$ & $\begin{array}{r}9.5 \\
66.6 \\
26.7 \\
8.0\end{array}$ & $\begin{array}{r}30.0 \\
55.0 \\
7.6 \\
16.0\end{array}$ & \multirow[t]{2}{*}{$\begin{array}{l}\text { Siderite. } \\
\text { Chamosite and hematite. } \\
\text { Spathic and brown ores. } \\
\text { Siderite and hematite. }\end{array}$} \\
\hline & 111.0 & 110.8 & 108.6 & \\
\hline
\end{tabular}


The accompanying ratio chart (fig. 31 ) shows the progress of iron mining in Austria and Hungary and in the Austro-Hungarian Empire as compared with the United States, Europe, and the world. It shows that the increase since 1880 has been consonant with the normal world increase.

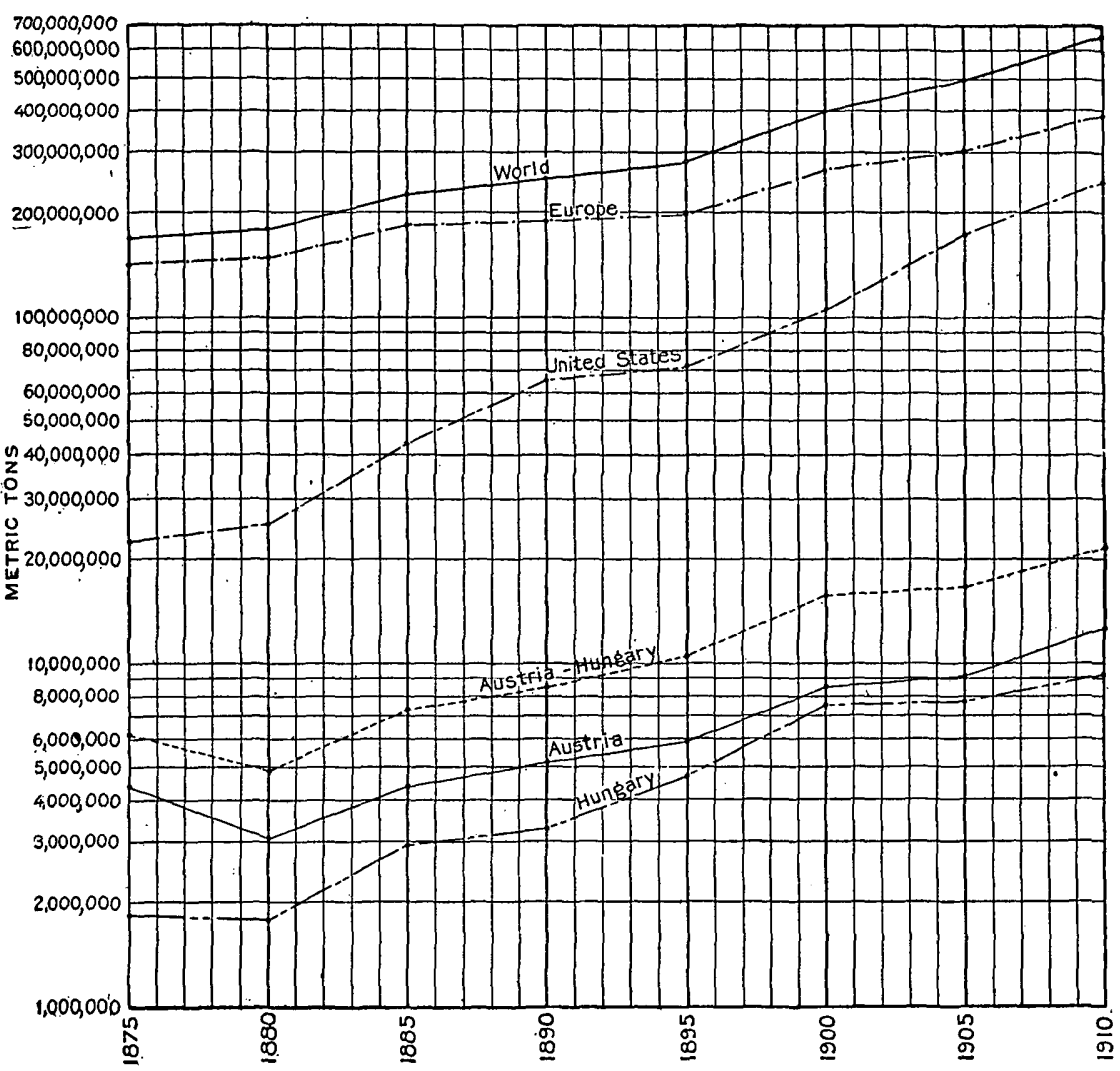

FIGURE 31.-Ratio chart showing iron ore produced during five-year periods ending 1875 to 1910 in the Austro-Hungarian Empire, Austria, Hungary, Europe, the United States, and the world. (See explanation of fig. 8, p. 41.)

In 1913 Austria-Hungary produced 5,318,531 metric tons of iron ore, divided as follows:

Austria

Metric tons.

Hungary

$3,039,324$

Bosnia.

$2,059,076$

Allocation of the output of the Empire for 1913 to the political divisions of 1919 aftords the result shown in the following table: 
Iron ore produced in countries that formed the Austro-Hungarian Empire, 1913.

\begin{tabular}{|c|c|c|}
\hline & Per cent. & Metric tons. \\
\hline 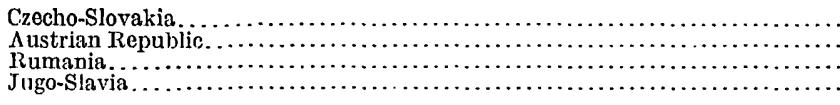 & $\begin{array}{r}47 \\
37 \\
12 \\
4\end{array}$ & $\begin{array}{r}2,500,000 \\
1,960,000 \\
640,000 \\
220,000\end{array}$ \\
\hline
\end{tabular}

In 1913 Austria-Hungary imported 14 per cent of the iron ore she consumed in her blast furnaces. Her production amounted to 5 per cent of the European total and her consumption to 5.5 per cent. (See figs. 5 and 6 , pp. 27, 28.)

As a result of the reconstruction Czecho-Slovakia will be in the best position to establish an iron and steel industry. She has more than enough coal within her borders to make her independent, and she has the iron ores of central Bohemia, the March Valley, and SzepesGömör-sufficient to supply her needs for some time to come.

The Austrian Republic, in the Styrian Erzberg and Carinthian Hüttenberg, also has a supply of excellent ore, but she is dependent on other countries for coke.

\section{THE BALKAN STATES.}

The only one of the Balkan States that had any but a small unreported local iron-ore industry in 1913 was Greece. Rumania and Jugo-Slavia get some of the deposits that contributed to make up the Austro-Hungarian total in 1913, but neither will have a large iron industry. (See Pl. XVI, in pocket.)

\section{BULGARIA.}

\section{Distribution, ChaRaCter, AND EXTENT OF THE DEPOSITS.}

The Bulgarian deposits are so very small that they can never be regarded as of more than local importance. They have been described by Scott, ${ }^{50}$ Muset, ${ }^{51}$ and Vankov. ${ }^{52}$

Bedded deposits of hematite are reported at Breznik and Kremikovci and lenses of magnetite at Krumovo and Rudin-Kamak. Also some slag that contains 50 per cent of iron is left from ancient workings at Samakov.

According to Vankov, ${ }^{53}$ the Bulgarian reserve amounts to $1,450,000$ metric tons, of which 950,000 metric tons is slag. The reserve has been estimated as containing probably 700,000 metric tons of iron.

${ }^{50}$ Scott, J.. K., Notes on some Bulgarian mineral deposits: Inst. Min. and Met. Trans., vol. 22, pp. 597$615,1913$.

51 Muzet, A., L'industrie minérale dans les Balkans: Soc. ind. min. Bull., vols. 14-15, pp. 113-151, 1911.

52 Vankov, Lazar, Die Eisenerzlagerstätten im Königreich Bulgarien: The iron-ore resources of the world (11th Internat. Geol. Cong.), vol. 1, pp. 331-339, Stockholm, 1910.

${ }^{\text {ss Idem, p. } 339 .}$ 
PRODUCTION AND CONSUMPTION.

There are no figures to show the production of iron ore in Bulgaria and nothing on which to base an expectation of a future iron industry there.

\section{GREECE. ${ }^{54}$}

DISTRIBUTION, CHARACTER, AND EXTENT OF THE DEPOSITS.

The principal deposits of iron ore in Greece are the chromiferous ores in the Laurium Peninsula near Lake Kopais and on the islands of Euboea and Skyro. They are closely associated with Cretaceous serpentines, and the one point on which most geologists who have studied the deposits are agreed is that the ores were derived from the serpentine.

According to Nottmeyer ${ }^{55}$ these ores were deposited in a shallow sea on the serpentine from hydrothermal solutions. Scott ${ }^{56}$ regards the ores as segregations in the serpentine, fissure deposits in limestone, or contact deposits between Jimestone and serpentine. Habets ${ }^{57}$ regards them as original segregations from peridotite magma which were enriched by metasomatism during serpentinization of the peridotite.

The ore is described as consisting of nodules or shotlike grains of "brown hematite" cemented by a binder of more hydrated, softer amorphous ore. In places the ore shows a thinly banded structure. It usually occurs on top of serpentine and is covered by later limestone.

The ore is so very similar to Cuban lateritic and New Caledonian residual ores in occurrence and type that it is thought by the writer to be of the same origin-that is, the ores are regarded as due to weathering, essentially in place.

Deprat's studies in Euboea ${ }^{58}$ and Lepsius's work in Attica ${ }^{50}$ show that the serpentines are derived from basic igneous rocks intruded into Cretaceous limestones. These igneous rocks suffered dynamic metamorphism, which in places caused a rearrangement of their minerals and produced some schistosity. This schistosity might be preserved after serpentinization and lateritization and might give some of the ore a banded structure, whereas the ore formed from

54 Vallindas, K., Geol. Centralbl. vol. 9, pp. 425-426 (abstract), 1917. Scott, H. K., Iron and Steel Inst. Jour., 1913, No. 1, pp. 447 et seq. Cottrell, - (U. S. consul), Mining industry of Cyclades: Min. Jour., vol. 75, p. 661, 1903. Habets, A., and Bonanos, N., Rev. univ. des mines, vol. 21, pp. 129-148, 1908. Reports on iron deposits in foreign countries, Board of Trade, London, 1905. Nottmeyer, Max, Die Eisenerzvorräto Griechenlands: The iron-ore resources of the world (11th Internat, Geol. Cong.), vol. 1, pp. 341-349, Stockholm, 1910.

65 Op. cit., p. 345.

${ }^{56}$ Scott, H. K., Iron and Steel Inst. Jour., 1913, No. 1, pp. 447 et seq.

${ }^{67}$ Habets, A., and Bonanos, N., Rev. univ. mines, vol. 21, pp. 129-148, 1908.

${ }^{68}$ Deprat, J., Etude géologique de l'île d'Eubée, 217 pp., maps and photographs, Besançon, 1904.

59 Lepsius, R., Geologie von Attika, Berlin, 1893. 
massive serpentine by lateritization-that is, by weathering in place-would be granular, an explanation that is borne out by the sharp contacts between the ore and the limestone and the more indefinite contacts between the ore and the serpentine, noted by Scott. The occurrence of the ore in fissures in limestone could be accounted for by assuming migrating solutions during or after lateritization. A careful physiographic and paleogeographic study would be necessary to test the hypothesis advanced.

The estimates of the reserves are not very definite. Nottmeyer says there are $75,000,000$ to $100,000,000$ metric tons in the Laurium district. The ore contains about 45 per cent of iron, 2 per cent of chrome, and from 0.01 to 2.20 per cent of phosphorus.

Iron resources of Greece.

[Millions of metric tons.]

\begin{tabular}{|c|c|c|}
\hline & Ore. & Iron. \\
\hline 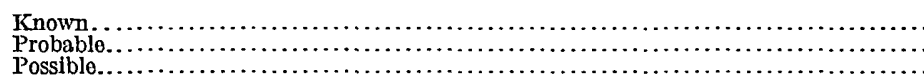 & $\begin{array}{l}40 \\
40 \\
50\end{array}$ & $\begin{array}{l}18.0 \\
18.0 \\
22.5\end{array}$ \\
\hline
\end{tabular}

Besides the deposits described there are small deposits of iron ore on some of the islands south of Greece.

On Zea there are some highly manganiferous ores near Spathi. They contain 49 per cent of iron and 22 per cent of manganese. On Syra there are some slightly manganiferous ores, and on Cerigo, Thermia, and Serpho there are deposits of hematite. Though some of these small deposits have been mined no estimates of their content of ore are available and they are not included in the reserves.

PRODUCTION AND CONSUMPTION.

Greece produces about 300,000 tons of chromiferous iron ore, which is used in European furnaces. As she lacks coal she has not and proably will not have an important iron industry.

RUMANIA. ${ }^{60}$

DISTRIBUTION, CHARACTER, AND EXTENT OF THE DEPOSITS.

The information concerning deposits of iron ore in Rumania is very scanty. The greater part of Rumania is plains country of a type in which one would scarcely expect to find any kind of ore, but in the hilly region of Dobrudja ore has been reported, and in the foothills of the Transylvanian Alps magnetite lenses in schist are said to occur between Podeni and Obirsa. Brown ores in limestone

${ }^{60}$ Poni, P., Études sur Ies minéraux de la Roumanie: Univ. Jassy Annales sci., vol. 1, pp. 15-148, 1901. 
are found on Mount Dirmoxa. So far as known there are no estimates of the reserves.

The most extensive ore deposits that Rumania gains by the accession of territory from Hungary are those of the Banat and Hunyad districts, in the Siebenbürgen country, whose location is shown in figure 32. These deposits ${ }^{61}$ consist of beds of spathic ore, which is altered to brown ore near the surface. There are some small bodies of magnetite in the district, but they are of very little value.

The carbonate and brown ores of the Hunyad district have been carefully studied by Von Papp, ${ }^{62}$ and according to his estimate the district can be credited with "known" resources of 3,700,000 metric

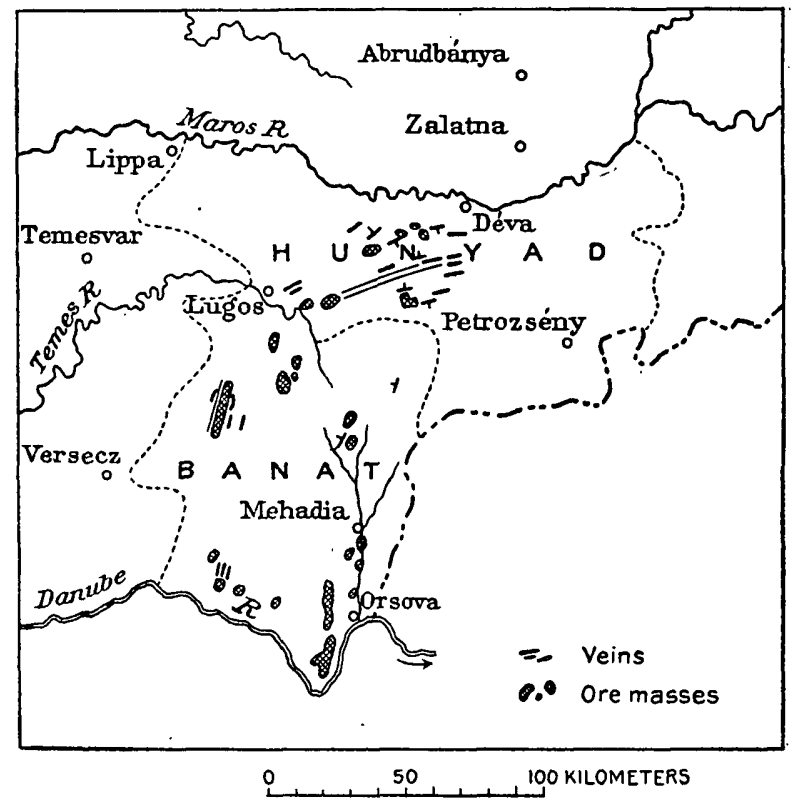

FIGURE 32.-Map showing deposits of iron ore in the Banat and Hunyad districts, Rumania.

tons of ore and "probable" resources of 13,300,000 metric tons. The ore averages about 44 per cent of iron and from 0.04 to 0.1 per cent of phosphorus. The estimate gives no information on which to base possible reserves, except to say that there are some $3,800,000$ metric tons of jasper and flinty ores which are not now available, and as they do not seem likely to become available they are omitted. In terms of metallic iron the district can be credited with "known" resources of 1,500,000 metric tons and with "probable" resources of $5,500,000$ metric tons.

61 Loczy, Ludwig von, and Papp, Karl von, Die im ungarischen Staatsgebiete vorhandenen Eisenvorräte: The iron ore resources of the world (11th Internat. Geol. Cong.), vol. 1, pp. 245-262, Stockholm, 1910.

${ }^{62}$ Idem, p. 262 . 
Besides the Hunyad district there are smaller deposits of iron ore all along the inner side of the Karpathian arc in the mountains of Siebenbürgen and on the northern and western planes of the Transylvanian Alps. These scattered deposits produced about 175,000 tons of ore a year in pre-war days, most of it from the complex mineral region of the Banat. No one of these districts is sufficiently large to be shown on the map by more than a cross. In the aggregate they can be counted on for "known" resources in metallic iron amounting to $1,000,000$ metric tons, "probable" resources amounting to $3,000,000$ metric tons, and "possible" resources amounting to $4,000,000$ metric tons.

Another part of former Austria-Hungary that is now mapped as a part of Rumania is the Bukowina ${ }^{63}$ Jakubeny, in the southern Bukowina, used to be the seat of a considerable iron industry. There seems to be very little prospect of reviving the industry under present conditions, although there undoubtedly are scattered small deposits in the neighboring parts of the Karpathians.

Iron resources of Rumania.

[Millions of metric tons of iron.]

\begin{tabular}{|c|c|c|c|}
\hline & Known. & Probable. & Possible. \\
\hline \multirow[t]{2}{*}{ 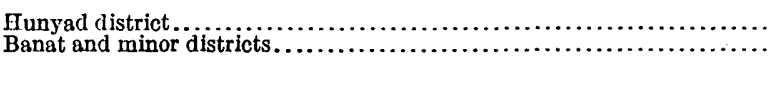 } & $\begin{array}{l}1.5 \\
1.0\end{array}$ & $\begin{array}{l}5.5 \\
3.0\end{array}$ & \\
\hline & 2.5 & 8.5 & 4 \\
\hline
\end{tabular}

PRODUCTION AND CONSUMPTION.

Details of the production of iron ore in Hungary are not available, so that it is not known how much of the production of Hungary should be allocated to deposits that have been given to Rumania, but the figure is probably not very large. However, next to Greece, Rumania, of all the Balkan States, has the best opportunity to develop an ironore industry, though she lacks the fuel for smelting on a large scale.

\section{JUGO-SLAVIA.}

Until the Adriatic question and the future of Albania have been decided the boundaries of the new Jugo-Slar State can not be definitely fixed. (See Pl. XVI, in pocket.) The only deposit of iron ore that will be affected by the settlement of these questions is that at Rubigo, in Albania (see p. 115), but as it seems to be a small

Waul, C. M., and Walther, B., Grundzüge der Geologie der Bukowina: K.-k. geol. Reichsanstalt Jahrb., vol. 26, p. 261, 1876. $15945^{\circ}-21-$ Bull. $706-8$ 
deposit its allocation will not seriously affect the estimate of iron-ore reserves.

SERBIA.

Milojkovitch ${ }^{64}$ states that there are many deposits of iron ore in Serbia and foresees a brilliant future for iron-ore mining in that country, but the information he gives is accompanied by no data that make it possible to estimate the reserves.

Vranja.-At Vranja, near the headwaters of Morava River, northeast of Uskup, there are masses of magnetite in crystalline schists. In this area there are also deposits of lead, iron, and copper sulphides, which were formerly mined, but the association throws doubt on the value of the magnetite deposits.

Suvo Rudishte.-In the orystalline schists of western Serbia near Suvo Rudishte there are a number of deposits of magnetite. The ore appears to contain much iron, but it contains also considerable sulphur. These small, scattered deposits can never be more than a source of supply for a small local industry.

Papratishte.-At Papratishte there is a hill on which hematite and brown ore lie between serpentine and Cretaceous limestone. The resemblance of the deposits to those in Greece near Lake Kopais suggests that this deposit may have future value.

Ralja and Guberevaz.--In northern Serbia, south of Belgrade, there are deposits of oolitio sedimentary ores, which contain much iron and considerable chromium. They appear to be valuable, but the information concerning them is so meager that it gives no idea of their extent.

Majdanpek ${ }^{65}$-The iron gossan of the deposits of pyrite and chalcopyrite at Majdanpek is useful as a flux but is scarcely of much value as an iron ore.

CROATIA AND SLAVONIA.

Croatia and Slavonia, which were once parts of Austria-Hungary but now form parts of Jugo-Slavia, contain few deposits of iron ore. There are some bedded brown ores and deposits of siderite near Tergove, ${ }^{60}$ in Croatia, as well as brown ores near the boundary of Carinthia and Bosnia. They form only a small reserve, which has not been oalculated.

\footnotetext{
64 Milojkovitch, J. A., Die Eisenerzvorkommen in Serbien: The Iron-ore resources of the world (11th Internat. Geol. Cong.), vol. 1, pp. 311-329, Stockholm, 1910.

${ }^{65}$ Wendeborn, B. A., Die Kupfererz und Limonit Lagerstätten von Majdanpek: Zeitschr. prakt. Geologie vol. 20, pp. 266-280, 1912.

$6_{6}$ Loczy, L. von, and Papp, K. von, Die im ungarischen Staatsgebiete vorhandenen Eisenerzvorräte (11th Internat. Gool. Cong.), vol. 1, pp. 275-278, Stockholm, 1910.
} 


\section{BOSNIA AND HERZEGOVINA. ${ }^{67}$}

There are several small deposits of iron ore in Bosnia and Herzegovina, most of them of little value at present, though the vast amount of slag in the dumps indicates that they were once the sources of a large industry.

The ore deposits of the district of Vares, northeast of Serajevo, in Bosnia, are still valuable. They consist of bodies of hematite and siderite, of metasomatic origin, deposited in limestones that now form part of a series of greatly metamorphosed sedimentary rocks.

Iron resources of the district of Vares, Bosnia.

[Millions of metric tons.

\begin{tabular}{|c|c|c|}
\hline & Ore. & Iron. \\
\hline 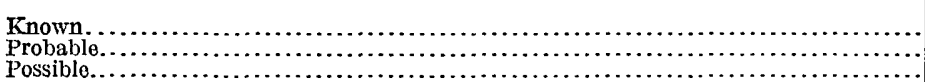 & $\begin{array}{l}21 \\
20 \\
40\end{array}$ & $\begin{array}{r}9.5 \\
8.0 \\
16.0\end{array}$ \\
\hline
\end{tabular}

This district is the only one in Jugo-Slavia whose reserves have been estimated, so that the figure for Vares and for Jugo-Slavia as a whole is the same. If applied to Jugo-Slavia this figure is obviously incorrect, but as there is no information on which to estimate the quantity of oro in the other deposits mentioned any additional figure would be an arithmetic expression of a mere guess.

In 1912 Bosnia and Herzegovina produced altogether about 200,000 tons of ore that was utilized in the furnaces of Trieste or in the home production of charcoal iron. There is no reason why this production should not be continued.

Jugo-Slavia lacks the coal that a more extensive domestic iron industry would require.

\section{ALBANIA.}

Iron ore is reported to occur near Rubigo, in Albania, but no information as to type or extent has been found.

\section{TURKEY IN EUROPE. ${ }^{68}$}

There is little available information regarding the iron ores of European Turkey, and they are believed to be of slight value. An investigation of coal deposits near Rodosto disclosed the occurrence of iron ore, and there is said to be magnetite sand and "schistose magnetite" at Samakov. The reserves are considered negligible.

or Katzer, F., Die TIsenerzlagerstiitten Bosniens und der Herzegowina: Berg-u. Hüttenm. Jahrb., vols. 57,58 , and $59,1909-1911$.

${ }^{63}$ Nottmeyer, Max, Die Eisenvorrïte der Turkei: The iron-ore resources of the world (11th Internat. Geol. Cong.), vol. 1, pp. 352-353, Stockholm, 1910. 


\section{RUSSTA.}

DISTRIBUTION, CHARACTER, AND EXTENT OF THE DEPOSITS.

\section{AREA CONSIDERED.}

The one thing certain about Russia seems to be that it will not have the same boundaries in the future that it had in 1913 . Finland can be accepted as a definite state, and in the present connection the boundaries of Poland are sufficiently established to permit its treatment as a definite state, particularly as the uncertainty in regard to its eastern boundary includes an area that lacks iron ore. The old Lett provinces of the Baltic contain no iron ore.

On the other hand, the vast territory that makes up the rest of old Russia also seems liable to subdivision. The differences between central and northern Russia and the Ukraine seem to be too great to permit peaceful fusion. The diverse interests of the Ural region, the Caucasus, and the Crimea may cause the formation of new political entities, but as they have not yet sufficiently risen out of the mists of civil strife to be clearly outlined they can be treated here only as geographic expressions.

In studying Russia reliance was placed chiefly on the work of Bogdanowitsch. ${ }^{69}$ Articles in Russian had to be studied through résumés in other languages or through the excellent short abstracts in the Geologisches Centralblatt.

\section{NORTHERN RUSSIA. ${ }^{70}$}

Lodes of hematite in diorite, brown sedimentary ores, and bog ores are reported from the Government of Olonetz. (See Pl. XVII, in pocket.) There is little information about them, but they are said to be unimportant.

\section{CENTRAL RUSSIA. ${ }^{71}$}

Metasomatic brown ores are reported from the Governments of Kaluga, Tula, Rjasan, Orel, Kursk, Voronezh, and Tambof. (Sce $\mathrm{Pl}$. XVIII, in pocket.) The ore contains about 40 per cent of iron. About 286,000 tons of it was produced in 1912. The estimates made by Bogdanowitsch form the basis for the figures given below.

\footnotetext{
${ }^{69}$ Bogdanowitsch, K., Die Eisenerze Russlands: The iron-ore resources of the world (11th Internat. Geol. Cong.), vol. 1, pp. 363-544, Stockholm, 1910.

${ }^{70}$ Schepowalnikoff, A., [Ore deposits of Tulomosersk district, Government of Olonetz]: Geol. Centralbl., v01. 2, p. 547 (abstract), 1902; [The ore deposits of Lake Tulmo, Government of Olonetz]: Geol. Centralbl., vol. 3, p. 327 (abstract), 1903. Bogdanowitsch, K., op. cit., pp. 516-518.

71 Bogdanowitsch, K., op. cit., pp. 485-494. Ernst, A., Die Kohlen und Eisenerzlagerstätten des centralen Russlands: Berg- u. Hüttenm. Zeitung, No. 50, 1900. Bogdanow, D., [Iron-ore deposits in Effremow district, Government of Tula]: Geol. Centralbl., vol. 3, p. 6 (abstract), 1903. Kobetski, J., [OnIwnian Iron ore, Government of Kursk]: Geol. Centralbl., vol. 3, pp. 35-36 (abstract), 1903,
} 
Iron resources of central Russia.

[Millions of metric tons.]

\begin{tabular}{|c|c|c|c|c|c|c|}
\hline \multirow{2}{*}{, } & \multicolumn{2}{|c|}{ Known. } & \multicolumn{2}{|c|}{ Probable. } & \multicolumn{2}{|c|}{ Possible. } \\
\hline & Ore. & Iron. & Ore. & Iron. & Ore. & Iron. \\
\hline \multirow[t]{2}{*}{ 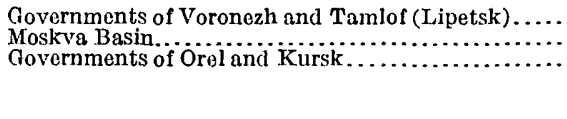 } & $\begin{array}{r}300 \\
50\end{array}$ & $\begin{array}{r}120 \\
20\end{array}$ & $\begin{array}{r}400 \\
50\end{array}$ & $\begin{array}{r}160 \\
20\end{array}$ & $\begin{array}{r}400 \\
75 \\
37\end{array}$ & $\begin{array}{r}160.0 \\
30.0 \\
14.1\end{array}$ \\
\hline & 350 & 140 & 450 & 180 & 512 & 201.1 \\
\hline
\end{tabular}

\section{SOUTHERN RUSSIA. ${ }^{72}$}

Krivoi Rog.-The most famous deposits of iron ore in Russia (see PI. XIX, in pocket) are those of Krivoi Rog, in southern Russia. $^{73}$ They are found in greatly metamorphosed schists and, according to Bogdanowitsch, are of similar origin to the ores of the Lake Superior region-that is, they are metamorphosed sediments. Their age has not been definitely established but is thought to be pre-Cambrian.

The ore mineral is hematite and the gangue is quartz. The ore contains 50 to 70 per cent of iron, but ore containing less than 56 per cent of iron is not mined. The content of phosphoric acid varies from 0.01 to 0.06 per cent.

The estimates available show considerable differences of opinion. An estimate made by Szymanowski ${ }^{74}$ in 1903 gives 57.5 million tons. An estimate made by Bogdanowitsch ${ }^{75}$ in 1910 gives 86,700,000 tons, and an estimate made by C. R. King ${ }^{76}$ in 1914 gives $206,000,000$ tons.

Iron resources of Krivoi Rog, Russia.

[Millions of metric tons.]

\begin{tabular}{|c|c|c|}
\hline & Ore. & Iron. \\
\hline 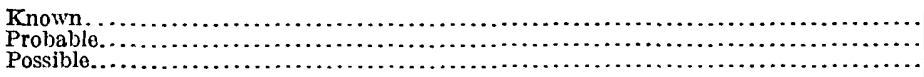 & $\begin{array}{r}50 \\
50 \\
100\end{array}$ & $\begin{array}{l}31 \\
31 \\
62\end{array}$ \\
\hline
\end{tabular}

74 King, C. R., Russia-its future as a coal and iron producer: Eng. Mag., vol. 48, pp. 481-492, 1915. The Russian iron industry and the Ukraine: Stahl u. Eisen, No. 12, 1918 (abstract in Chem. Industry, Feb. 28, 1919). Simmersbach, Bruno, Die südrussischen Eisenerzfelder von Krivoi Rog und Kertsch: Oesterr. Zeitschr. Berg- u. Hüttenwesen, vol, 62, pp. 253-257, 272-275, 288-291, 303-305, 1914. Bogdanowitsch, K., op. cit., pp. 501-516.

${ }^{73}$ Szymanowski, M., Krivoi-Rog: Soc. ind. min. Bull., vol. 14, 3d ser., pp. 1385-1459, 1900.

14 Szymano:vski, M., [Krivol Rog iron-ore reserves]: Geol. Centralbl., vol. 3, p. 35 (abstract), 1903.

76 Op. cit., p. 505.

${ }^{86} \mathrm{King}, \mathrm{C} . \mathrm{R}$, op. cit. 
Donetz.-In the Donetz Basin, ${ }^{77}$ east of Krivoi Rog, there are pockets of brown ore which at one time gave rise to great hopes and exaggerated estimates, but the hopes were disappointed and the ores are at present of little or no importance.

Kosak Mogila.-North of the Sea of Azof, at Kosak Mogila, ${ }^{78}$ there are small deposits of magnetite and hematite in metamorphic schists. Whether development might make them valuable is open to question. They appear to be of a type that is of great value in other countries:

Kerch.-On the east end of the Kerch peninsula ${ }^{79}$ there are extensive beds of oolitic ore, which are underlain by limestone of good fluxing quality. They contain 40 to 45 per cent of iron, about 2 per cent of manganese, 15 per cent of silica, and 1.3 per cent of phosphorus.

Iron resources of Kerch, Russia.

[Millions of metric tons.]

\begin{tabular}{|c|c|c|}
\hline & Ore. & Iron. \\
\hline $\begin{array}{l}\text { Known } \\
\text { Probable } \\
\text { Possible. }\end{array}$ & $\begin{array}{l}100 \\
250 \\
200\end{array}$ & $\begin{array}{r}40 \\
100 \\
80\end{array}$ \\
\hline
\end{tabular}

Summary of southern Russia.-The quantities of metallic iron in the iron-ore deposits in southern Russia are summarized bolow.

Iron resources of southern Russia.

[Millions of metric tons of iron.]

\begin{tabular}{|c|c|c|c|}
\hline & Known. & Probable. & Possible. \\
\hline \multirow[t]{2}{*}{ 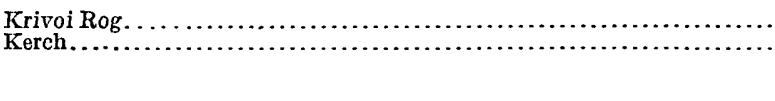 } & $\begin{array}{l}31 \\
40\end{array}$ & $\begin{array}{r}31 \\
100\end{array}$ & $\begin{array}{l}62 \\
80\end{array}$ \\
\hline & 71 & 131 & $\overline{142}$ \\
\hline
\end{tabular}

\section{CAUCASUS. ${ }^{80}$}

The only deposit in the Caucasus region concerning which reliable information is available is that at Daschkiessan, south of Elizabetopol, in Transoaucasia. (See Pl. XIX, in pocket.) It appears to be a contact-metamorphio deposit of high grade. The iron content of the ore is 62 per cent.

${ }^{n}$ Bogdanowitsch, K., op. cit., pp. 511-513.

${ }^{78} \mathrm{Idem}, \mathrm{p} .511$.

${ }^{79}$ Zeidler, R. [Kerch iron-ore district]: Geol. Centralbl., vol. 3, p. 5, 1903. Bayard, M., Note sur les gisements de minerais de fer des presqu'iles de Kertch et de Taman: Annales des mines,'9th ser., vol. 15, pp. 505-522, 1899.

${ }^{80}$ Besborodko, N., Über oine neue Chromeisenerzlagerstätten am nördlichen Kaukasus und ihre mineralogischen Verhältnisse: Noues Jahrb., Beilage Band, vol.34, pp. 783-798, 1912. Terpigorew, A. [Magnet. ite deposit of Daschkiessan, in the Caucasus]: Geol. Centralbl., vol. 3, p. 7 (abstract), 1903. 
Iron-ore resources of the Caucasus.

[Millions of metric tons.]

\begin{tabular}{|c|c|c|}
\hline & Ore. & Iron. \\
\hline 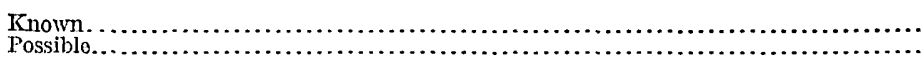 & $\begin{array}{l}10 \\
30\end{array}$ & $\begin{array}{r}6.2 \\
18.6\end{array}$ \\
\hline
\end{tabular}

URAL MOUNTAIN REGION. ${ }^{81}$

In the Ural Mountains and their foothills there are deposits of many kinds of iron ore and their descriptions give the impression that there is still much to learn about them. They will be taken up in order from north to south.

Bogoslovski estate. ${ }^{82}$-Most of the ore on the Bogoslovski estate is of igneous origin and appears to consist of contact-metamorphic bodies. The ore minerals are hematite and magnetite, which contain from 40 to 60 per cent of iron and 0.04 to 0.1 per cent of phosphorus.

Although there is plenty of ore for local production the reserve is small. (See Pl. XVII, in pocket.)

\section{Iron resources of the Bogoslovski estate, Russia.}

[Millions of metric tons.]

\begin{tabular}{|c|c|c|}
\hline & Ore. & Iron. \\
\hline $\begin{array}{l}\text { Known } \\
\text { Probable. } \\
\text { Possible.... }\end{array}$ & $\begin{array}{l}2 \\
1 \\
1\end{array}$ & $\begin{array}{r}1.0 \\
.5 \\
.5\end{array}$ \\
\hline
\end{tabular}

Troisk. ${ }^{83}$-At Troisk, on the western slopes of the Ural Mountains, there are contact-metamorphic deposits of iron ore. No data as to grade are at hand. The reserves, which consist of 3,000,000 metric tons of ore, are taken arbitrarily as containing 1,500,000 metric tons of iron. (See Pl. XVIII.)

Perm and Viatka. ${ }^{84}$-In the governments of Perm and Viatka, west of the Ural Mountains, there are argillaceous deposits of siderite of sedimentary origin. They cover large areas and furnish considerable ore to near-by smelters. They are of low grade in the crude state (22 per cent of iron), but they make good ores when roasted. (See Pl. XVIII.)

81 Boguanowitsch, K., op. cít., pp. 364-485. Preston, T. H., The Urals and their mineral wealth: Min. Mag., vol. 14, pp. 197-201 (with map), 1916.

${ }^{89}$ Keene, A. F., unpublished information. Fedorow, E., and Nikitin, W., [The Bogoslovski mining district]: Geol. Centralbl,, vol. 2, pp. 326-327 (abstract), 1902. Ouspensky, L., [On Bogoslovski]: Geol. Centralbl., vol. 3, p. 36, 1903. Shockley, W., The Bogoslovski mining estate: Am. Inst. Min. Eng. Trans., vol. 39, pp. 274-302, 1908.

\&s Duparc, L., and Mrazec, L., Sur le mineral de fer de Troisk (Oural du Nord): Compt. Rend., vol. 136, pp. 1409-1411, 1903. Mrazec, L., and Duparc, L., Über dio Brauneisensteinlagerstïtten des Bergreviers von Kisel im Ural (Kreis Solikamsk des permschen Gouvernements): Oesterr. Zcitschr. Berg- u. Hüttenwesen, vol. 51, pp. 711-715, 735-740, 1903.

84 Bogdanowitsch, K., op. cit., pp. 472-477. 
Iron resources of Perm and Viatka, Russia.

[Millions of metric tons.]

\begin{tabular}{|c|c|c|}
\hline & Ore. & Iron. \\
\hline 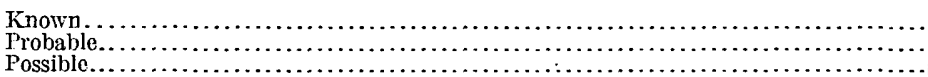 & $\begin{array}{l}20 \\
20 \\
20\end{array}$ & $\begin{array}{l}4 \\
4 \\
4\end{array}$ \\
\hline
\end{tabular}

Gora Blagodat-Nizhni Tagilsk region. ${ }^{85}$-Concentrating ores occurring in gabbro and containing 27 per cent of iron, oolitic hematite ores containing 37 per cent of iron, and high-grade magnetite ores containing 55 per cent of iron are found in the Gora Blagodat-Nizhni Tagilsk region. Most of the reserve is of the type last named. (See Pl. XVIII.) The estimate given below is based on the details given by Bogdanowitsch.

Iron resources of Gora Blagodat-Nizhni Tagilsk region.

[Millions of metric tons.]

\begin{tabular}{|c|c|c|}
\hline & Ore. & Iron. \\
\hline 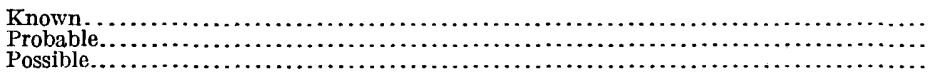 & $\begin{array}{l}10 \\
10 \\
10\end{array}$ & $\begin{array}{l}5.0 \\
5.0 \\
4.5\end{array}$ \\
\hline
\end{tabular}

Versk Isetsk. ${ }^{86}$-There are metasomatic deposits of brown ore and hematite in the central Ural region. (See Pl. XVIII.) The brown ores contain about 50 per cent of iron and 0.11 per cent of phosphorus; the hematite contains 56 to 60 per cent of iron and little phosphorus. The estimate given below is based on private reports.

Iron resources of the central Ural region.

[Millions of metric tons.]

\begin{tabular}{|c|c|c|}
\hline & Ore. & Iron. \\
\hline $\begin{array}{l}\text { Known.... } \\
\text { Probable.. }\end{array}$ & $\begin{array}{r}6.5 \\
11.5\end{array}$ & $\begin{array}{l}3.3 \\
5.8\end{array}$ \\
\hline
\end{tabular}

Alapaievsk district.-East of the Ural region, but still in European Russia, in the Alapaievsk district, there are extensive beds of metasomatic brown ores. (See Pl. XVIII.) Bogdanowitsch's sketches indicate that the ore is of surficial origin. It contains about 44 per cent of iron.

${ }^{85}$ Loewinson-Lessing, F., [On the magnetite deposit of Gora Blagodat]: Geol. Centralbl., vol. 12, p. 170 (abstract), 1909.

${ }^{88}$ Nikitin, V. [On the geology of Versk-Isetzk]: Com. géol. Mém. 22, 1907. Russian with French abstract. 
Iron resources of the Alapaievsk distrist, Russia.

[Millions of metric tons.]

\begin{tabular}{|c|c|c|}
\hline & Ore. & Iron. \\
\hline 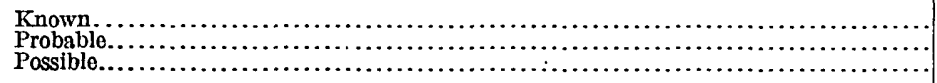 & $\begin{array}{l}30 \\
70 \\
50\end{array}$ & $\begin{array}{l}13.2 \\
28.0 \\
20.0\end{array}$ \\
\hline
\end{tabular}

Bilimbaievsk.-Ores similar to those of Alapaiersk occur in the Ural region in the Bilimbaievsk area. The reserve amounts to $1,000,000$ metric tons of ore, containing 500,000 metric tons of iron.

Sissert estate. ${ }^{87}$-There are 38 deposits of iron ore on the Sissert estate. They are magnetite and brown ores. From company reports the "known" reserve is estimated at 1,000,000 metric tons of metallic iron, and the "possible" reserve at 2,500,000 metric tons. This estate includes the famous Kyshtim copper mines. (See Pl. XVIII.)

Ufalievski district.-Reports indicate that the Ufalievski district, in the central Ural region, contains every kind of iron ore known in the Ural Mountains. It is credited with 3,000,000 metric tons of iron, but this estimate is very likely to prove too low.

Bakalsk district. ${ }^{88}$-Scattered deposits of brown ore occur in the Bakalsk district, in the southern part of the Ural region. (See Pl. XVIII.) The ore averages about 50 per cent of iron.

Iron resources of the Bakalsk district.

[Millions of metric tons.]

\begin{tabular}{|c|c|c|}
\hline & Ore. & Iron. \\
\hline 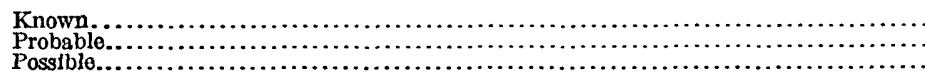 & $\begin{array}{l}26 \\
26 \\
10\end{array}$ & $\begin{array}{r}13 \\
13 \\
5\end{array}$ \\
\hline
\end{tabular}

Magnitnaia Gora. ${ }^{80}$-Magnitnaia Gora, a famous jron mountain, lies on the east slope of the southern Ural range. (See Pl. XVIII.) The main ore body is a segregation of magnetite and hematite in gabbro. The estimate below includes some highly titaniferous ores and some brown ores in the Kussinskaja district.

${ }^{87}$ Keene, A. F., unpublished information.

${ }^{88}$ Bauermann, $\mathrm{H}$. [On the iron-ore deposits of the Ural: Iron and Steel Inst. Jour., 1898, No. 1, pp. 134145. Koniouchevsky, L. [Geologic study in Bakalsk region]: Geol. Centralbl., vol. 4, p. 310 (abstract) 1904.

${ }^{89}$ Morozewicz, J., Die Eisenerzlagerstätten des Magnetberges (Magnitnaia Gora) im südlichen Ural und ihre genesis: Min. pet. Mitt., vol. 23, pp. 113-152, 225-262, 1904. 
Iron resources of Magnitnaia Gora and the Kussinskaja district

[Millions of metric tons.]

\begin{tabular}{|c|c|c|}
\hline . & Ore. & Iron. \\
\hline 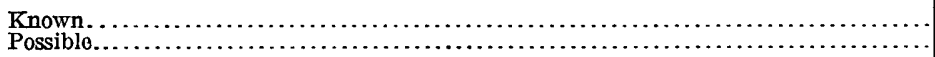 & $\begin{array}{l}25 \\
25\end{array}$ & $\begin{array}{l}11.3 \\
11.3\end{array}$ \\
\hline
\end{tabular}

Summary of the Ural Mountain region.-In the subjoined summary of the iron resources of the Ural Mountains the reserves given are probably low. The excellent and complete report of Bogdanowitsch presents a multitude of geologic details, and its estimates of the reserves that could be checked by those in other reports have almost always proved to be moderate. Many deposits are mentioned for which no estimates are made.

Iron resources of the Ural Mountain region.

[Millions of metric tons of iron.]

\begin{tabular}{|c|c|c|c|}
\hline & Known. & $\begin{array}{l}\text { Prob- } \\
\text { able. }\end{array}$ & Possible. \\
\hline 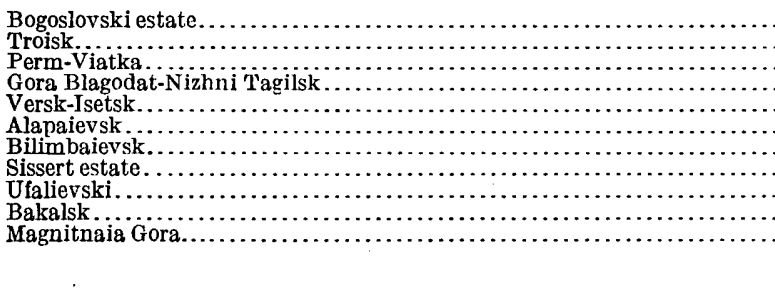 & \begin{tabular}{r}
1.0 \\
\hdashline .0 \\
5.0 \\
3.3 \\
13.2 \\
.5 \\
1.0 \\
\hdashline 13.0 \\
11.3 \\
52.3
\end{tabular} & \begin{tabular}{r}
0.5 \\
1.5 \\
4.0 \\
5.0 \\
5.8 \\
28.0 \\
$\ldots \ldots . .$. \\
\hdashline$\ldots .0$ \\
3.0 \\
13.0 \\
$\ldots \ldots .$. \\
60.8
\end{tabular} & 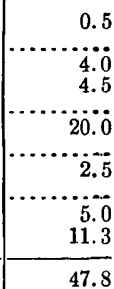 \\
\hline
\end{tabular}

SUMMARY OF RUSSIA.

The quantities of iron in the deposits in the subdivisions of Russia here considered are tabulated below.

Iron resources of Russia.

[Millions of metric tons of iron.]

\begin{tabular}{|c|c|c|c|}
\hline & Known. & $\begin{array}{l}\text { Prob- } \\
\text { able. }\end{array}$ & Possible. \\
\hline 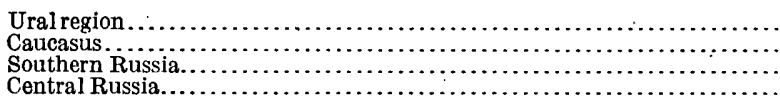 & $\begin{array}{r}52.3 \\
6.2 \\
71.0 \\
140.0\end{array}$ & $\begin{array}{r}60.8 \\
6.2 \\
131.0 \\
180.0\end{array}$ & $\begin{array}{r}47.8 \\
18.6 \\
142.0 \\
204.1\end{array}$ \\
\hline . & 269.5 & 378.0 & 412.5 \\
\hline
\end{tabular}




\section{PRODUCTION AND CONSUMPTION.}

The development of an iron industry in Russia has been adversely affected by political conditions since 1900 . The ratio curve of production for the period preceding 1900 (see fig. 33) shows a steady increase, but since then there has been practically no increase, and for the five-year period ending 1915 there was probably a very large decrease.

The bases of an iron industry-coal, iron, and a population capable of using finished products-undoubtedly exist in Russia. Southern

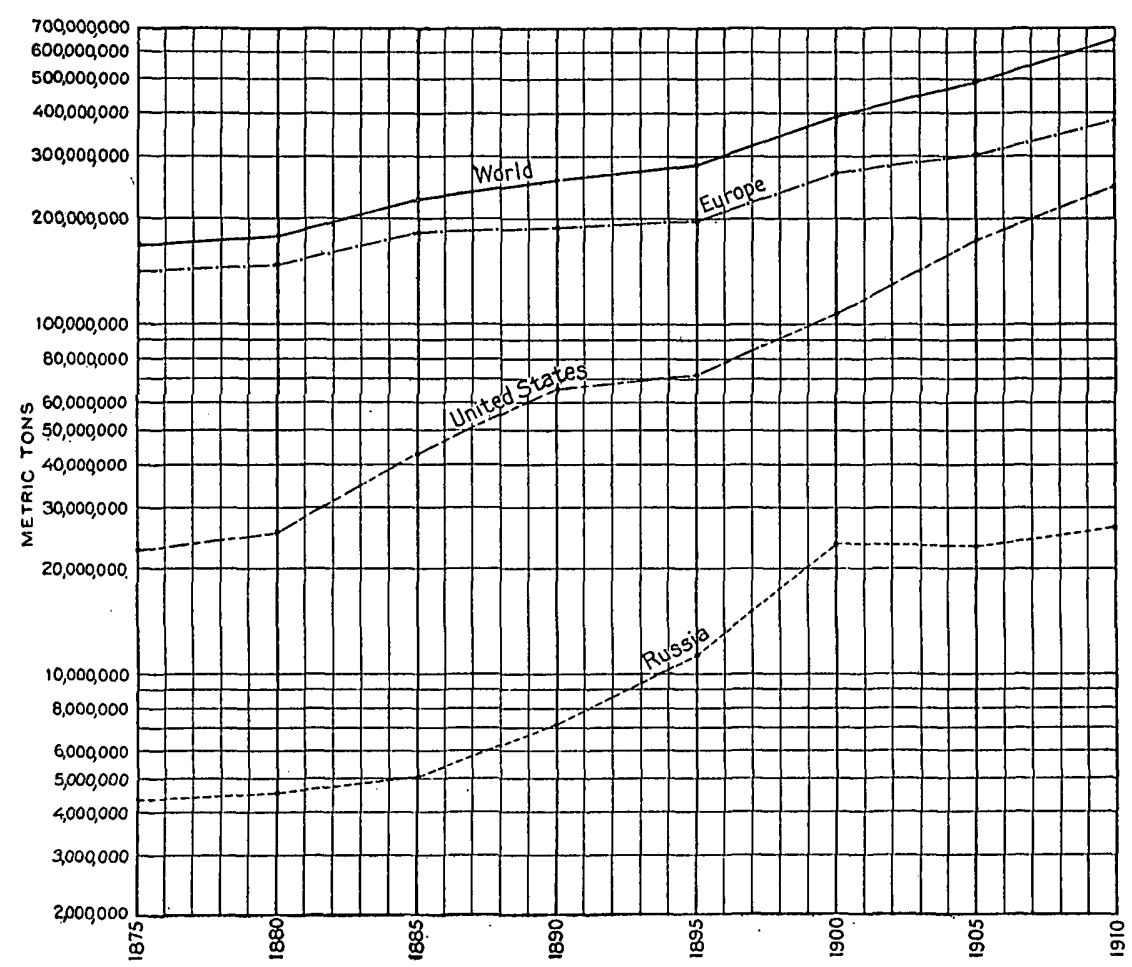

FIGURE 33.-Ratio chart showing iron ore produced during five-year periods ending 1875 to 1910 in Russia, Europe, the United States, and the world. (See explanation of fig. 8, p. 41.)

Russia, including the country of the "Little Russians" (Ukrainians) and the Crimea, is particularly fortunate. The iron ores of Krivoi Rog and Kerch and the Donetz coal basin are in this region, and the independent farm system of its black-earth belt makes the region a less fertile field for political agitation than central Russia, with its communal farming aggregates, and offers a more ready and more intelligent market for finished products. However, for some time to come politics rather than industry will dominate the former Empire of the Czars, and its future is not easy to foretell. 


\section{BIBLIOGRAPHY.}

The books and articles listed in this bibliography comprise a part of the material consulted. Many articles that were found to be unreliable or that were proved to be written for purposes of "propaganda" have been omitted. Owing to the shortness of the time available the literature issued prior to 1900 was not examined so thoroughly as that of later date.

\section{WORKS OF A GENERAL NATURE.}

GENERAI ARTICLES ON RESERVES.

EckeL, E. C., Iron ores, McGraw-Hill Book Co., 1914.

Study of "occurrence, valuation, and control" of iron ores. Contains summaries of many estimates and much detail on American ores and an excellent discussion of the reserves of foreign countries.

Great Britain, Board of Trade, Reports on iron deposits in foreign countries. L̇ondon, 1905.

Compilation of information from diplomatic and consular officers.

Great Britain, Department of Scientific and Industrial Research, Advisory CouncIL, Report on the source and production of iron and other metalliferous ores used in the iron and steel industry, London, 1918.

Most recent compilation. Gives excellent résumé of more important occurrences.

I International Geological Congress, The iron-ore resources of the world, 2 vols. and atlas, Stockholm, 1910.

Comprehensive and detailed study of the iron-ore reserves of the world by many authors, cited individually below. Used as basis for the greater-part of this work.

11th session, Compt. rend., 1910.

Discussion of and additional notes to "The iron-ore resources of the world." Törneвонм, A. E., Eisenvorräte der Welt: Glückauf, vol. 41, pp. 1542-1546, 1905.

Abstract of Törnebohm's report to Swedish Parliament, which instigated the making of estimates for the International Geological Congress in 1910. Törne- ' bohm overestimated the relative importance of Swedish iron ores.

DISCUSSIONS OF QUESTIONS OF RESERVE BASED ON WORK OF TENTH INTERNATIONAL GEOLOGICAL CONGRESS.

Beyschlag, F., Mitteilungen über die Eisenerzvorräte der Welt: Int. Kongress für Bergbau, etc., Düsseldorf, Berichte über prakt. Geologie, pp. 13-22, 1910.

Boker, H. E., Glückauf, vol. 47, pp. 420-427, 457-466, 499-507, 1911.

Critical study and review of Einecke and Köhler on German resources in particular and of "The iron-ore resources of the world" and of the discussions at the 11th session of the International Geological Congress at Stockholm, 1910.

CAMpbell, H. H., Iron-ore reserves of the world: Iron Age, vol. 99, pp. 51-53, 1917.

Calculates that reserves will last 800 years at present rate of production but will be exhausted in 1990 if production increases at present rate.

KRUSCH, P., Zeitschr. Berg-, Hütten- u. Salinenwesen preuss. St., vol. 62, pp. 176$216,1914$.

Critique of "The iron-ore resources of the world," p. 194. Says comparison of countries based on work of International Geological Congress is impossible because economic features were not taken into account. 
The iron-ore resources of the world: Zeitschr. prakt. Geologie, Bergwirtschaftliche Mitteilungen, vol. 18, 1910.

Beyschlag, F., on reserves, pp. 209-217.

Lindman, A., on policy, particularly Sweden, pp. 217-220.

Kemp, J. F., on future, pp. 220-224.

De Launay, L., review and future, pp. 224-228.

\section{TEXTBOOKS ON GEOLOGY OF IRON ORES IN GENERAL.}

Beyschlag, F., Krusch, P., and Vogt, J. H. L., Die Lagerstätten der nutzbaren Mineralien und Gesteine, 2 vols., Stuttgart, F. Enke, 1913.

Consulted for geology of some of the European deposits.

Lapparent, A. de, Traité de géologie, 5th ed., Paris, Masson et Cie.,1906.

Used for historical geology and paleogeographic maps.

Launay, de L., Gîtes minéraux et métallifères, 3 vols., Paris, Ch. Béranger, 1913.

Excellent for discussions of geology of most European deposits.

Irndgren, Watidemar, Mineral deposits, McGraw-Hill Book Co., 1913.

Consulted for geology of iron ores in general.

\section{ARTICLES ON DIFFERENT PHASES OF IRON-ORE GEOLOGY.}

Bencke, A., Neue Ausschauungen über die Entstehung des oolithischen Eisenerzes: Oesterr. Zeitschr. Berg- u. Hüttenwesen, vol. 22, pp. 297-299, 1914.

Excellent discussion of formation of oolitic ores.

Clarke, F. W., The data of geochemistry, 3d ed.: U. S. Geol. Survey Bull. 616, 1916.

Consulted forochemistry of iron ores and the quantity of iron in earth's crust.

KRUSCF, P., Primäre und secundäre metasomatische Prozesse auf Erzlagerstätten: Zeitschr. prakt. Geologie, vol. 18, pp. 165-180, 1910.

Considers contact metasomatism, vein metasomatism, metasomatic deposits in modern sense, and oxidation and cementation metasomastism, and gives classification.

LEITH, C. K., Use of geology in iron-ore exploration: Econ. Geology, vol. 7, pp. 662$675,1912$.

Posnjak, E., and Merwin, H. E., The hydrated ferric oxides: Am. Jour. Sci., 4th ser., vol. 47 , pp. 311-348, 1919.

Latest laboratory work on "brown ores." Changes entire conception of earlier ideas on limonite series.

Sosman, R. B., and Hostetrer, J. C., The ferrous iron content and magnetic susceptibility of some artificial and natural oxides of iron; zonal growth in hematite and its bearings on the origin of certain iron ores: Am. Inst. Min. Eng. Trans., vol. 58 , pp. 409-433, 433-444, 1917.

Study of relation between $\mathrm{Fe}_{2} \mathrm{O}_{3}$ and $\mathrm{Fe}_{3} \mathrm{O}_{4}$, more especially as they occur in ore deposits of igneous origin.

Vogt, J. H. I., Untersuchungen über die Ausscheidungen von Titan-Eisenerzen in basischen Eruptivgesteinen: Zeitschr. prakt. Geologie, vol. 8, pp. 233-242, 370382, 1900; vol. 9, pp. 9-20, 180-186, 289-296, 327-340, 1901.

Studies of basic segregations.

Über Manganwiesenerz und über das Verhältniss zwischen Eisen und Mangan in den See- und Wiesenerzen: Zeitschr. prakt. Geologie, vol. 14, pp. 21.7-233, 1906. On the origin of bog iron ores.

Über magmatische Ausscheidungen von Eisenerz im Granit: Zeitschr. prakt. Geologie, vol. 15 , pp. 86-89, 1907.

Excellent article on the mode of formation of deposits of igneous origin associated with acidic rocks, 
GENERAL STATISTICAL SOURCES.

Roush, G. A., editor, Mineral Industry, McGraw-Hill Book Co.

Gives export and import as well as production statistics.

Sveriges Officiella Statistik, Bergshantering, 1916.

European production statistics since 1871 in one table. Used for rate diagrams.

United States Geological Survey, Mineral Resources of the United States.

- Consulted for figures of production, more especially used for making diagram of growth of Lake Superior production.

BIBLIOGRAPHY.

Iron and Steel Institute Journal, London.

Annotated bibliography in volumes from 1900 to 1917 furnished references that served as basis for much of the work.

\section{AUSTRIA.}

Badermann, H., The Erzberg of Eisenerz (Styria): Iron and Steel Inst. Jour., 1907, No. 3, pp. 27-36.

General description.

BuAss, J., Über ein Eisenerzvorkommen im Stubaithale: Zeitschr. prakt. Geologie, vol. 8, pp. 369-370, 1900.

Description of some magnetite-hematite deposits at base of Triassic dolomites near Neustift, south of Innsbruck, Austrian Alps. No reserves.

Canaval, R., Das Eisensteinvorkommen zu Kohlbach an der Stubalpe (Steiermark): Berg- u. Hüttenm. Jahrb., vol. 52, pp. 145-158, 1904.

History with review of discussion of genesis.

- Natur und Enstehung der Erzlagerstätten am Schneeberg in Tirol: Zeitschr. prakt. Geologie, vol. 16, pp. 479-483, 1908.

A discussion of genesis, true veins, and metasomatic replacements.

HörHAGER, J., Das Eisensteinvorkommen bei Neumarkt in Obersteier: Oesterr. Zeitschr. Berg- u. Hüttenwesen, vol. 51, pp. 337-339, 1903.

History and general description of abandoned deposit of magnetite-hematite at contact of limestone and mica schist.

HuMphrey, W. A., Über einige Erzlagerstätten in der Umgebung der Stangalpe: K.-k. geol. Reichsanstalt Jahrb., vol. 55, pp. 349-368, 1905.

Includes geologic description of iron-ore deposits in Styria and Carinthia, Austria.

JонN, C. V., and Eichleiter, C. F., Arbeiten aus dem chemischen Laboratorium der K.-k. geol. Reichsanstalt, 1901-1903: K.-k. geol. Reichsanstalt Jahrb., vol. 53,

- pp. 480-514, 1903; vol. 57, pp. 403-436, 1907.

Analyses of many samples including iron ores.

KestraneK, W., The Austrian iron industry during the last twenty-five years: Iron and Steel Inst. Jour., 1907, No. 3, pp. 10-24.

Austria short of coking coal. Bohemian reserves of low phosphorus giving out.

NAGEL, O., Iron-ore output at the Styrian Erzberg: Iron Age, vol. 94, pp. 482-484, 1914.

Reserve $206,000,000$ tons rich ore (about 38 per cent), $157,000,000$ tons lean ore (less than 25 per cent). Good description and pictures; mostly mining methods.

Redurich, K. A., Die Eisensteinbergbaue der Umgebung von Payerbach-Reichenau

(Nieder-österreich): Berg- u. Hüttenm. Jahrb., vol. 55, pp. 267-294, 1907.

Description, history, and geology of some deposits that were abandoned in 1902 and 1903.

Über das Alter und die Enstehung einiger Erz- u. Magnetitlagerstätten der steierischen Alpen: K.-k. geol. Reichsanstalt Jahrb., vol. 53, pp. 285-294, 1903.

Argument for epigenetic origin. 
Singewald, J. T., The Erzberg in Styria: Eng. and Min. Jour., vol. 92, pp. 22-24, 1911.

Quotes 200,000,000 tons estimate. Good résumé of the work of others.

Statistik des Auswärtigen Handels des Oesterreich Ungarisches Zollgebietes.

Used for statistical information.

Statistik des Bergbaues in Osterreich, Vienna. Official statistics.

VACEK, M., Skizze eines geologischen Profils durch den steierischen Erzberg: K.-k. geol. Reichsanstalt Jahrb., vol. 50, p. 23, 1900.

Gives data on age of deposits. Not in accord with other authors, who disagree with his idea that some of the ore beds are Permian.

\section{BELGIUM.}

Delmer, A., La question du minerai de fer en Belgique: Annales des mines de Belgique, vol. 17, pp. 853-940; vol. 18, pp.325-448, 1912-13.

Complete with maps. Covers the subject very thoroughly.

KerLback, K., Die Eisenerzlagerstätten des belgischen Kempenlandes: Glückauf, vol. 54, No. 24 (with map), June 15, 1918; abstract in Soc. Ind. Chem. Jour., vol. 37, p. $342 \mathrm{R}, 1918$.

Brings out two types of ore-brown ores of "altalluvial" or diluvial origin and "Raseneisenerze" of "jungdiluvial" origin.

Iambert, Guillaume, Découverte d'un puissant gisement de minerais de fer, etc., Brussels, 1904.

Maps, sections, bore holes, and analyses of the iron ores in the Campine coal basin.

Schulz-Briesen, B., Glückauf, vol. 41, pt. 1, pp. 37-42, 1905.

Critical review of article by Lambert cited above. The black-band ores in the Campine coal fields are of better grade than the ore of the Staffordshire fields. Ore is deep and probably workings would be wet.

Statistique des industries extractives, etc.

Official statistics.

\section{BULGARIA.}

Muzet, A., L'industrie minérale dans les Balkans: Soc. ind. min. Bull., vols. 14-15, 1911.

Maps showing Serbian and Bulgarian mineral deposits. Short description of deposits, laws, and general condition of the industry.

Scoтr, H. K., Notes on some Bulgarian mineral deposits: Inst. Min. and Met. Trans., vol. 22, pp. 597-615, 1913.

VAN Kov, L., Die Eisenerzlagerstätten im Königreich Bulgarien: The iron-ore resources of the world (11th Internat. Geol. Cong.), vol. 1, pp. 331-339, Stockholm, 1910.

Good details, estimate, and map.

\section{CZECHO-SLOVAKIA.}

Вӧскн, H., Die geologische Verhältnisse des Vashegy, des Hradek und der Umgebung Dieser [Comitat Gömör].

$\Lambda$ good detailed description of the occurrence of siderite veins with limonite capping. Contains maps and sections.

Katzer, F., Zur Genesis der Zbuzaner Eisenerzlager, Böhmen: Oesterr. Zeitschr. Berg- u. Hüttenwesen, vol. 53, pp. 390-391, 1905.

Argument for genesis of deposit near Dobric by removal of calcium carbonate from spathic limestone; taken from K.-k. geol. Reichsanstalt Verh. No. 2, 1905. 
Kretschmer, F., Die Eisenerzlagerstätten des Mährischen Devon: K.-k. geol. Reichsanstalt Jahrb., vol. 49, pp. 29, 1899.

Detailed study.

Die Sinterbildung vom Eisenerzbergbau Quittein nächst Müglitz (Mähren):

K.-k. geol. Reichsanstalt Jahrb., vol. 52, pp. 353-494, 1902.

Mineralogy.

Lóczy, Ludwig von, and PAPP, KARL voN, Die im ungarischen Staatsgebiete vorhandenen Eisenerzvorräte: The iron-ore resources of the world (11th Internat. Geol. Cong.), vol. 1, pp. 178-223, Stockholm, 1910.

Sснмпт, L. von, Zur Entwickelungsgeschichte des Maramaroser Bergbaues: Oesterr. Zeitschr. Berg- u. Hüttenwesen, vol. 50, pp. 219-224, 1902.

Historical review of mining in Maramaros, on south slope of Karpathians, in eastern Hungary (eastern part of Czecho-Slovakia).

Tietz, E., Die geognostischen Verhältnisse der Gegend von Landskron und Gewitsch. [northeastern Bohemia]: K.-k. geol. Reichsanstalt Jahrb., vol. 51, pp. 317-730, 1901.

General areal geology with an occasional reference to occurrences of iron ore.

Vort, F. W., Geognostische Schilderung der Lagerstättenverhältnisse von Dobschau in Ungarn [Szepes-Gömör]: K.-k. geol. Reichsanstalt Jahrb., vol. 50, pp. 695-727, 1900.

Bibliography. Pure geology.

Weber, K. A., Der Eisenerzbergbau Ungarns: Glückauf, vol. 50, pp. 1193-1203, 1238-1249, 1914.

Accepts statements of reserves in "The iron-ore resources of the world." Gives excellent brief description of industry and occurrence in Szepes-Gömör, KrassoSzöreny (Banat), and Hunyad. Says others amount to only 2 per cent.

FINLAND.

Tiegerstedt, A. F., Magnetiska undersökningar i trakten af Jussarö: Fennia [Finnish Geog. Soc. Bull.], vol. 14, No. 8, pp. 1-19, 1898.

German abstract. Maps. Describes magnetic survey resulting in establishing existence of large submarine ore bodies near Jussarö.

Trustedt, O., Die Erzlagerstätten von Pitkäranta am Ladoga-See: Comm. géol. Finlande Bull. 19, 1907.

A 333-page monograph on the geology of the deposits.

Finland's economic ore deposits, as taken from consular reports: Zeitschr. prakt. Geologie, vol. 15, pp. 294-302, 1907.

No iron industry in northern part. Iron ore most important wealth. Lake ores scattered and impure. Wälimäki (Pitkäranta?) only mine operating on good ore. Good historical notes and industrial review.

Notes on iron-ore deposits near Kittelä (Finland): Min. Jour., vol. 87, pp. 375-375, 1909.

Journalistic article of uncertain value.

\section{FRANCE.}

Anser, H., Die oolitische Eisenerzformation deutsches Lothringen: Zeitschr. prakt. Geologie, vol. 9, pp. 81-94, 1901.

Maps, sections, good description from various points of view, and a careful study of the origin of the ore.

Barlly, L., Exploitation du minerai de fer oolithique de la Lorraine: Annales des mines, 10th ser., vol. 7, pp. 5-55, 1905.

Description and discussion of Lorraine ịnon industry, with ạn interesting diagrammatiç forescașțt, 
Beltanger, E., Les minerais de fer de l'Anjou: La Nature, 1911.

Description of deposits.

Note sur l'importance probable du gisement ferrifère de l'Anjou: Annales des mines, 10th ser., vol. 20, pp. 452-456, 1911.

Discusses geology and economics of Anjou ore. Estimates exploitable ore at $1,000,000,000$ tons, considering only ore carrying 44 per cent of iron or more as exploitable.

Broot, A., Le bassin minière de la Basse-Normandie: Rev. gén. sci. pures et appl., vol. 24, pp. 258-263, 1913.

Geology with maps and sections. A comprehensive and detailed study.

L'exploitation des mines de fer de la Basse-Normandie: Rev. gén. sci. pures et appl., vol. 24, pp. 346-352, 1913.

Mining in Normandy.

Burchard, E. F., Iron ore, pig iron, and steel in 1917: U. S. Geol. Survey Mineral Resources, 1917, pt. 1, pp. 557-603, 1918.

Source of statistics on production of Lake Superior iron ore. Used for diagram to compare output of Lorraine and of Lake Superior regions.

Cayeux, L., Structure et origine probable du minerai de fer magnétique de Dielette: Compt. Rend., vol. 142, pp. 716-718, 1906.

Genesis of Dielette ore, which is regarded as of contact-metamorphic origin or more probably of contact-metamorphic superimposed on sedimentary origin.

Les minerais de fer oolithiques de France, Paris, Ministère des travaux publics, 1909.

Study of ores of Normandy as published to date.

Le minerai de Lorraine, Paris, 1918.

A description of the Lorraine ore field and a discussion of its future. With the conclusion that it is to the advantage of France to mine the ores of Normandy and Brittany-Anjou for export to England and to continue exporting Lorraine ores to Westphalia there can be no quarrel, but some of the data on which the conclusion is based and the animadversions on German estimates are open to question. The remark that ores of the Armorican peninsula form a reserve comparable to that of the Lorraine field is worth noting.

Coup d'œil sur les minerais de fer de la presqu'île armoricaine: Soc. franç. min. Bull., vol. 41, p. 134, 1918.

A new estimate of the iron ores of the Normandy-Brittany-Anjou oolitic ores. Raises estimate from the $220,000,000$ tons of "The iron-ore resources of the world" to $1,824,500,000$ tons.

Ferasson, L., La question du fer, Paris, Payot et Cie., 1918.

The Franco-German problem. Much excellent information on the iron industry and an interesting study of future conditions.

Grossouvre, Albert De, Gisements de fer en grains du centre de la France: Annales des mines, 8th ser., vol. 10, pp. 311-418, 1886 .

Geologic study, with considerable history but few economic data.

GuILLET, LÉon, La métallurgie française, son passé, son avenir, 208 pp., Soc. ing. civ., April-June, 1918.

Study of past and future in French metallurgy. Many comparative diagrams. An exhortation for industrial combination and a plea for a "reasonable" protective tariff.

Heurteau, C. E., Note sur le minerai de fer silurien de Basse-Normandie: Annales des mines, 10th ser., vol. 11, pp. 613-668, 1907.

Description and good discussion of economic features.

$15945^{\circ}-21-$ Bull. $706 \longrightarrow 9$ 
Kohlmans, W., Die Minnetteablagerung des Iothringischen Jura: Stahl und Eisen, vol. 22 , pt. 1, p. 493,1902 .

Detailed geologic study.

Die neuere Entwicklung des lothringischen Eisenerzbergbaues: Stahl und Eisen, vol. 31, pt. 1, pp. 413-424, 469-479, 544-556, 1911.

A complete study of mining, geology, and reserves, with map and statistical tables. This is the most thorough study of the Lorraine Basin that was available. KRECKE, F., Eisenerz und Kohle in Französisch-Lothringen: Glückauf, vol. 46, pt. 1, pp. 4-9, 1910.

Description of iron ore in Lorraine and of borings for coal in Pont-à-Mousson, a continuation of the Saar Basin.

KruSch, P., Das neue Deutschland, March 15, 1918.

Original article was not available. Comment following is based on French translation. Article on allocation of raw materials for German iron industry. Estimates 4,700,000,000 tons of ore for Normandy. Interesting as part of wartime literature giving German point of view.

Lrnch, M. C., Why France needs the Briey Basin: Iron Trade Rev., vol. 60, p. 924, 1917.

Translation from article by a French expert. Shows possible realinement of iron ore, iron, and steel industry in France and Germany as the result of war.

Masse, R., Contribution à l'étude géologique des gîtes minerais de la Normandie: Annales des mines, 10th ser., vol. 1, pp. 581-609, 1902.

Largely a study of geologic structure.

MAulde, J. DE, Les mines de fer et l'industrie métallurgique dans le Département du Calvados, Caen, 1916.

A historical study with a map.

Mercey, N. DE, Sur l'origine du minerai de fer hydroxydé en Bray: Compt. Rend., vol. 127, pp. 1245-1248, 1898.

A note upon the age and mode of formation. No economic data.

Merz, V., Das Vorkommen der oolitischen Eisenerze in Lothringen und Luxemburg: Stahl und Eisen, vol. 10, pp. 677-690, 1890.

Gives some early cost data.

Mutroun, F., German wiles gain Normandy ore: Iron Trade Rev., vol. 62, p. 1311, 1918.

Says there are $5,000,000,000$ tons of ore immediately available in Normandy. Quotes Krusch's estimate of 4,700,000,000 tons. Gives 45 per cent as average grade. A propagandist article, chiefly of interest as a sign of the times.

Nicou, P., Les ressources de la France en minerais de fer, Paris, 1911.

Same account as in "Iron-ore resources of the world," except for a few additional economic data.

- The iron-ore deposits of eastern and western France: Iron and Steel Inst. Jour., 1914, No. 2, pp. 131-164.

Brief description with maps.

Oentert, D. P., Sur les minerais de fer ordoviciens de la Basse-Normandie et du Maine: Compt. Rend., vol. 146, pp. 516-517, 1908.

Brief review of information on Normandy ore.

Peyre, —-, Sur le gisement de fer Palmesalade: Soc. ind. min. Bull., 2d ser., vol. 13, pp. 5-32, 1884.

Good brief description and discussion of economic and genetic questions.

Pralon, L., Note sur le minerai de fer carbonaté en Normandie, etc.: Annales des mines, 9th ser., vol. 19, pp. 125-148, 1901.

Geology and technology. 
Rigaud, F., Notice sur ıes minières de la Haute-Marne: Annales des mines, 7th ser., vol. 14 , pp. 9-62, 1878 .

Geology and mining of the Jurassic oolitic ores of Haute-Marne. Gives cost data.

Statistique de l'industrie minérale, 1913, Paris, Ministère des travaux publics, etc., Direction des mines, 1917.

Official statistics.

VillaIn, M., Le gisement de minerai de fer oolithique de la Lorraine: Annales des mines, 10th ser., vol. 1, pp. 113-322, 1902.

Comprehensive study that has been the source of most of the French articles on Lorraine. Villain's map has been used by Nicou, Cayeux, and others. Details on Briey field. Made French estimate.

\section{GERMANY.}

BAumLer, — Über das Vorkommen von Eisensteine im westfälischen Steinkohlengebirge: Zeitschr. Berg-, Hütten- und Salinenwesen preuss. St., vol. 1.7, pp. 426-478, 1869.

Exhaustive article with analyses and map.

BerG, G., Die Magneteisenerzlager von Schmiedeberg: K.-preuss. geol. Landesanstalt Jahrb., 1902, pp. 201-266.

Geology of Schmiedeberg region and deposits. Presents a theory that ore was formed by the "Auswanderung" of silica from basic igneous rock as a contactmetamorphic effect leaving a concentration of magnetite.

BeyschlaG, F., Die Erzlagerstätten der Umgebung von Kamsdorf in Thüringen: K.preuss. geol. Landesanstalt Jahrb., pp. 329-377, 1888.

Geology of the siderite veins near Kamsdorf, with brief treatment of history and economic features.

—Die Eisenerze des Vogelberges: Zeitschr. prakt. Geologie, 1897, pp. 337-338.

Description of occurrence and method of working.

- Karte der nutzbaren Lagerstätten Deutschlands: K.-preuss. geol. Landesanstalt Jahrb.

Maps giving outlines of mineral areas and outcrops of deposits, and data on production.

Bцомеке, C., Die Gang- und Erzvorkommen des Schwarzwaldes: Zeitschr. prakt. Geologie, 1894, pp. 414-418.

Geologic description.

Boprfes, - U Über die Genesis der Eisen- und Manganerzvorkommen im Taunus:

Zeitschr. prakt. Geologie, vol. 15, pp. 309-316, 1907.

Shows deposits to be of either metasomatic or sedimentary origin.

BorNHARDT, W., Über die Gangverhältnisse des Siegerlandes und seine Umgebung: K.-preuss. geol. Landesanstalt Archiv für Lagerstättenforschungen, Heft 2, 19:?

A 415-page monograph on the Siegerland veins.

BÜcking, H., Der nordwestliche Spessart: K.-preuss. geol. Landesanstalt Abh., nev: Folge, Heft 12, p. 148, 1892.

A geologic bulletin, with only a brief discussion of the ore deposits.

Cheurus, C. R. L., Eisen und Mangan im Grossherzogtum Hessen: Zeitschr. rrakt. Geologie, vol. 12, pp. 356-362, 1904.

Description of occurrence and of the economic conditions.

Denkeskampr, R., Die technisch nutzbaren Mineralien und Gesteine des Taunus:

Zeitschr. prakt. Geologie, vol. 11, pp. 265-276, 1903.

Description of ores and statistics of production. 
EnNecke, G., and KöhleR, W., Die Eisenerzvorräte des deutschen Reiches: K.preuss. geol. Landesanstalt Archiv für Lagerstättenforschungen, Heft 1, Berlin, 1910.

Data used in "The iron-ore resources of the world". given in a much more comprehensive form. The most complete study of the country available.

ERmisch, K., Die Knollengrube bei Lauterberg am Harz: Zeitschr. prakt. Geologie, vol. 12, pp. 160-172, 1904.

A study of the economic geology of the Lauterberg district. Analyses and mine plans.

Flunr, R., Die Eisenerzlagerstätten Württembergs: Zeitschr. praltt. Geologie, vol. 16, pp. 1-23, 1908.

Geology, economics, and history of iron ores of Württemberg.

Freise, F., Zur Entwicklungsgeschichte des Erzbergbaues in den deutschen Rheinlanden: Zeitschr. prakt. Geologie, vol. 15, pp. 1-19, 1907.

History of mining in the Rhine country prior to the Thirty Years' War. Of interest to the historian only.

Frohwein, E., Beschreibung des Bergreviers Dillenburg, Bonn, 1885.

Comprehensive report, covering occurrences, geology, and statistics.

Hanrmann, —, Die Eisenerze des Hüggelś bei Osnabrück: Zeitschr. prakt. Geologie, vol. 17, pp. 343-353, 1909.

Geology and mining, with estimates.

HARBort, E., Zur Frage nach der Entstehung gewisser devonischer Roteisenerzlagerstätten: Neues Jahrb., 1903, Band 1, pp. 179-192.

A valuable and clear contribution to the theories of genesis of these ores.

Hasslachen, A., Beiträge zur älteren Geschichte des Eisenhüttenwesens im Saargebiete: Zeitschr. Berg-, Hütten- u. Salinenwesen preuss. St., vol. 44, pp. 75-97, 1896.

Saar iron works now depending on Lorraine ores were started on ores from Saar coal measures. First mentioned in 1430 . Traces historj to nineteenth century.

HatzFeld, C., Die Roteisensteinlager bei Fachingen an der Lahn: Zeitschr. prakt. Geologie, vol. 14, pp. 361-365, 1906.

Geology and origin of Devonian ores of Lahn district.

HolzapFex, E., Die Eisenerzvorkommen in der Fränkischen Alb: Glückauf, vol. 46, pt. 1, pp. 341-350, 1910.

Describes geology and occurrence briefly. Gives ownership. Estimates a reserve of $1,500,000,000$ tons. . Ore can generally be mined by open cut. Average of 300 analyses shows 38.5 per cent iron and over 20 per cent silica. Full discussion of genesis.

JÜNGST, - Die Manganeisenerzvorkommen der Grube Elisenhöhe bei Bingerbrück: Glückauf, vol. 43, pt. 2, pp. 993-998, 1907.

Description and discussion of geology.

Krockmann, F., Die eluvialen Brauneisenerze der nördlichen Fränkischen Alb bei Hollfeld in Bayern: Stahl und Eisen, vol. 28, pt. 2, pp. 1913-1919, 1908.

Description of occurrence and discussion of genesis.

Über kontaktmetamorphe Magnetitlagerstätten: Zeitschr. prakt. Geologie, vol. 12, pp. 73-85, 1904.

A biased article, trying to show that most contact-metamorphic deposits are of syngenetic origin. Peculiar rather than valuable.

KNACKstedt, E., Geol. u.. Bergmännisches vom Harzburger Eisenstein: Berg- u. Hüttenm. Zeitung, vol. 61, pp. 169-172, 181-185, 1902.

Description of geology and mining of the Jurassic ores in the Harz Mountains. More geology than mining. 
KöвRICH, E., Die Eisenerzlagerstätten in Oberhessen, die heutigen Aufschlüsse und ihre zukünftige Bedeutung: Stahl und Eisen, vol. 34, pt. 1, pp. 393-399, 445449, 1914.

An excellent description of economics and geology of the iron-ore occurrences in Upper Hesse. Map and illustrations.

Kollmann, F., Die Erzlagerstätten für Thomas Roheisen in Hannover und Braunschweig: Stahl und Eisen, vol. 6, pt. 2, pp. 787-788, 1886.

An early description of the Salzgitter and Iselde districts. Has historical value and shows importance of Thomas process.

Krahmann, M., Über Lagerstätten-Schätzungen im Ausschluss an eine Beurteilunğ der Nachhaltigkeit des Eisenerzbergbaues an der Lahn: Zeitschr. prakt. Geologie, vol. 12, pp. 329-348, 1904.

A plea for a study of reserves and a suggested method.

Krecke, F., Sind die Roteisensteinlager des nassauischen Devons primäre oder sekundäre Bildungen? Zeitschr. prakt. Geologie, vol. 12, pp. 348-355, 1904.

Answers his question in favor of primary origin.

KRUPP, OTto, Die Versorgung der niederrheinisch-westfälischen Hochofenwerke mit Eisenerz und die schwedische Eisenerzfrage: Stahl und Eisen, vol. 31, pp. 486-490, 1911; Glückauf, vol. 47, pt. 1, pp. 114-124, 160-167, 201-206, 1911.

Discussion with statistics and diagrams of the Swedish ore export question. Gives forecast of future. Shows dependence of German furnaces on Sweden.

Krusch, P., Der Südrand des Beckens von Münster: K.-preuss. geol. Landesanstalt Jahrb., 1908, pt. 2, pp. 1-110.

Geology of part of coal basin, with a few remarks on the associated clay iron stones.

___ Die Eisenerzvorkommen der untern Kreide im Westen des Beckens von Münster: Glückauf, vol. 54, pp. 261-268, 1918.

Description of deposits. Written to arouse interest in these large and at present idle ore deposits. Does not show that it is feasible to work them now.

—— Die Einteilung der Erz: Zeitschr. prakt. Geologie, vol. 15, pp. 129-139, 1907.

Brief discussion of the mineralogy of ore deposits, and the significance of the minerals as criteria of the method of formation.

Loretz, H., Der Zechstein in der Gegend von Blankenburg und Königsee am Thüringer Walde: K.-preuss. geol. Landesanstalt Jahrb., vol. 10, pp. 221-245, 1892.

Notes on the Zechstein formation, with only a brief reference to ore deposits.

Lorz, H., Die Dillenburger Rot- und Magneteisenerze: Deutsch. geol. Gesell. Zeitschr., vol. 54, pp. 139-141, 1902.

Beitrag zur Kenntnis vom Alter der Siegerländer Erzgänge: Zeitschr. prakt. Geologie, vol. 15, pp. 251-253, 1907.

Lowag, J., Mangan und Eisenerzvorkommen im Thüringerwalde: Oesterr. Zeitschr. Berg- u. Hüttenwesen, vol. 50, pp. 608-611, 623-625, 635-636, 1902.

Geologic description. Ascribes origin to solutions rising from below.

Mruroun, F., An iron girdle vs. a belt of gold: Iron Trade Rev., vol. 60, pp. 1030-1031, 1917.

Written under the influence of war. Credits Normandy-Anjou with 10,000,000,000 to $20,000,000,000$ tons of ore.

MÜNsTER, H., Die Brauneisenerzlagerstätten des Seen- und Ohmtals am Nordrand des Vogelgebirges: Zeitschr. prakt. Geologie, vol. 13, pp. 242-258, 413, 1905.

Description and discussion of origin leading to the theory that the ores are of $\mathbf{a}$ hydrothermal rather than an old lateritic type.

Resow, W., Das Ganggebiet des "Eisenzecher Zuges": Zeitschr. prakt. Geologie, vol. 16, pp. 305-328, 1908.

Study of Siegerland vein deposits. 
Riemand, W., Das Vorkommen der devonischen Eisen- und Manganerze in Nassau: Zeitschr. prakt. Geologie, 1894, pp. 50-57.

Geologic description.

Rose, - Z Zur Frage der Entstehung der nassauischen Roteisensteinlager: Zeitschr. prakt. Geologie, vol. 16, pp. 497-501, 1908.

Note on the discussion as to the origin of the Devonian ores of the Lahn district.

Rothpletz, A., Über die Amberger Erzformation: Zeitschr. prakt. Geologie, vol. 21, pp. 249-260, 1913.

Geology, with special stress on geologic history.

Russwurm, —, Neue Aufschlüsse von Magneteisenerz im Thüringerwalde: Glückauf, vol. 43, pt. 1, pp. 163-164, 1907.

Brief note on Schmiedefeld deposits.

SchlEgEL, KARL, Das Magneteisenerzlager vom Schwarzen Krux bei Schmiedefeld im Thüringer Wald: Deutsch. geol. Gesell. Zeitschr., vol. 54, pp. 24-55, 1902.

Geology of a contact-metamorphic magnetite deposit.

Sснмптт, A., Württemberg's Erzbergbau in der Vergangenheit: Glückauf, vol. 43, pt. 2, pp. 1034-1042, 1907.

Gives the rise and fall of ore exploitation in Jurassic and Bohnerz deposits.

Stutzer, O., Über die Entstehung und Einteilung der Eisenerzlagerstätten: Zeitschr.

Berg-, Hütten- u. Salinenwesen preuss. St., vol. 54, pp. 301-304, 1906.

Classification of iron ores. Excellent except that lateritic ores have been given no part in the classification.

Venator, W., Die Bedeutung der Siegerländer Eisenerzvorkommen für die Versorgung der deutschen Eisenindustrie: Stahl und Eisen, vol. 27, pt. 1, pp. 127-131, 1907.

Vierschming, A., Die Eisen- und Manganerzlagerstätten im Hunsrück und Soonwald: Zeitschr. prakt. Geologie, vol. 18, pp. 393-431, 1910.

Description of occurrences and mines, with discussion of geology.

Vouxz, H., Die Bergwerks- und Hüttenverwaltung des oberschlessischen IndustrieBezirks, Kattowitz, 1892.

A historical and statistical guide.

Werveke, L. von, Magneteisen in Minetten: Zeitschr. prakt. Geologie, 1895, p. 97; 1896, p. 68.

Brief note on occurrence and possible mode of formation, which the author ascribes to interaction of ferric hydrate and thuringite.

Wrese, T., Die nutzbaren Eisensteinlagerstätten im Wesergebirge bei Minden: Zeitschr. prakt. Geologie, vol. 11, pp. 217-230, 1903.

Geology, ore deposits, and genesis.

Das Vorkommen von oolithischen Roteisensteinen im Wesergebirge bei Minden, Giesen, 1903.

Description of deposits and interesting discussion of theories of genesis.

WruERT, — Das Toneisensteinvorkommen von Ahaus und Koesfeld [BentheimOchtrup-Ottenstein]: Glückauf, vol. 44, pt. 1, pp. 304-309, 1908.

Brief description. Detailed discussion of costs. His conclusion is that if the value of roasted clay ore is 15 to 16 marks or less these deposits can not be worked.

ZALINSKI, E. R., Untersuchungen über Thuringit und Chamosit aus Thüringen:

Neues Jahrb., Beilage Band, vol. 19, pp. 40-84, 1904.

A scientific investigation of origin and mineralogy.

Basic steel and the war: Iron Age, p. 586, Sept. 5, 1918.

An editorial on the importance of the basic steel industry in the war. 
Bavarian ores: Soc. Ind. Chem. Jour., vol. 37, p. 342 R, 1918 (abstract from Iron and Coal Trade Rev., Aug. 9, 1918).

Bavarian ores increasing in importance, chiefly in Upper Palatinate and Upper Franconia. In 1904 production was 180,342 tons; in 1913, 485,254 tons. Reserve, $150,000,000$ to $200,000,000$ metric tons.

Die schwedische Erzausfuhrfrage im deutschen Reichstage: Stahl und Eisen, vol. 27, pp. 25-29, 1907.

A discussion in the Reichstag of the export regulations of Swedish ore. Germany's need for more ore is stated.

Eisenerze in Schlesien und Posen: Zeitschr. prakt. Geologie, vol. 14, p. 62, 1906.

Notice of an intention to resume production of bog ores.

Note on Sweden's latest regulation: Stahl und Eisen, vol. 27, pt. 1, pp. 533-534, 1917. Vierteljahrshefte zur Statistik des deutschen Reichs.

Official statistics of Germany and Luxemburg.

\section{GREECE.}

Condelda, A., La Grèce, géologique et minéralogique, Paris, 1878.

Volume prepared for Paris Exposition.

[Mineral deposits and industry of Greece]: Annales des mines, 10th ser., vol. 2, p. 478, 1902.

Abstract of a conference at Sylloque. Brief with few details.

Cotrelu, - (U. S. consul), Mining industry of Cyclades: Min. Jour., vol. 75, p. 661. 1904.

Syra of small importance. Serpho exported 166,662 tons in 1903; 50 per cent iron, slightly manganiferous; $1,000,000$ tons reserve. Zea, several small deposits, 50 per cent iron, manganiferous. Thermia exported 41,650 tons in 1.903 from three deposits.

Deprat, J., Étude géologique de l'île d'Eubée, 217 pp., maps and photographs, Besançon, 1904.

Geologic study. No ore deposits.

Habets, A., and Bonanos, N., Rev. univ. mines, vol. 21, pp. 129-148, 1908.

Brief description of geologic occurrence of iron ores in Greece. Metasomatism and segregation supposed to account for them.

LEPsius, R., Geologie von Attika, Berlin, 1893.

A study of metamorphism, with special reference to Greek marbles. Contains petrographic descriptions of serpentines and rocks from which they are derived.

Scotr, H. K., Iron and Steel Inst. Jour., 1913, No. 1, p. 447.

Article with map and description of chromiferous iron ore of Kopais district and some comparisons with Cuban ores of lateritic type and some data on other deposits of chromite. Mentions Greek mining law. Useful article.

Valimndas, K., [Geology of iron-ore deposits of Serpho]: Geol. Centralbl., vol. 9, pp. 425-426, 1907 (abstract).

\section{ITALY.}

Bonacossa, A., [Geological and mineral note on Brosso deposits]: Geol. Centralbl., vol. 2, p. 232, 1902 (abstract by V. Novarese).

Note on geology, especially genesis.

Bonney, T. G., The magnetite mines near Cogne: Geol. Soc. London Quart. Jour., vol. 59, pp. 55-63, 1903.

Argument for genesis by differentiation.

$\mathrm{C}_{\Delta L V I}, \mathrm{G}$., The production of iron ores in the Brembana Valley: Iron and Steel Inst. Jour., 1911, No. 2, pp. 380-389.

A brief description of the Bergamo-Brescia district from the economist's viorpoint with a plea for its development. 
CapaCcr, C., The iron mines of the island of Elba: Iron and Steel Inst. Jour., 1911, No. 2, pp. 412-450, map.

Interesting historical data. Brief general geology. Details of occurrences. Discussion of genesis. Mining methods, statistics. An excellent article.

Catani, R., The iron-ore deposits of Piedmont: Iron and Steel Inst. Jour., 1911, No. 2, pp. 353-363.

Good general economic description, more especially of Cogne.

- The applications of electricity in the metallurgical industry of Italy: Iron and Steel Inst. Jour., 1911, No. 2, pp. 215-239.

Description and discussion.

Ciampi, A., The iron-ore deposits of central Italy: Iron and Steel Inst. Jour., 1911, No. 2, pp. 390-408.

Excellent description with a little of geology but mostly economics. Short bibliography.

CrIDA, A., Le miniere di Traversella: La metallurgia italiana, vol. 3, No. 5, pp. 231-239. Descriptive and economic.

Dompe, L., and Puccr, F. S., The present state of the iron industry in Italy: Iron and Steel Inst. Jour., 1911, No. 2, pp. 239-306.

An excellent detailed description and optimistic view of the future.

Duenkel, - Bericht über eine im Jahre 1900 ausgeführte Bereisung der Insel Sardinien und einiger anderer Bergreviere Italiens: Zeitschr. Berg-, Hütten- u. Salinenwesen preuss. St., vol. 50, pp. 622-668, 1902.

A long and apparently thorough description.

LоттI, B., Die geologischen und tektonischen Verhältnisse der Erzlagerstätten Nordost. Siziliens: Zeitschr. prakt. Geologie, vol. 15, pp. 62-66, 1907.

Describes some magnetite-blende deposits in phyllite in northeastern Sicily.

Müller, F. C., Die Erzlagerstätten von Traversella im Piemont: Zeitschr. prakt. Geologie, vol 20, pp. 209-240, with geologic map, 1912.

Comprehensive geologic study of the district and its ore deposits.

Novarese, V., Die Erzlagerstätten von Brosso und Traversella im Piemont: Zeitschr. prakt. Geologie, vol. 10, pp. 179-187, 1902.

Economic geology; no statistics.

Peters, F., La Vallée d'Aoste et ses principaux gîtes métallifères: Rev. univ. mines, vols. 39-40, pp. 97-116, 1912.

Good article on genesis and general geology of the deposits.

Poech, F., Die Eisenindustrie auf der Insel Elba: Oesterr. Zeitschr. Berg- u. Hüttenwesen, vol. 51, pp. 365-371, 1903.

Description, geology, and statistics.

Priehausser, M., Die Nickelmagnetkieslagerstätten von Varallo-Sesia, Prov. Novara: Zeitschr. prakt. Geologie, vol. 17, pp. 104-116, 1909.

Another case of magmatic differentiation with lodelike forms difficult to explain.

RIstorI, G., I giacimenti limonitici (Campiglia Marittima): Soc. toscana sci. nat. Atti, vol. 20, pp. 60-75, 1904.

Description of extensive low-grade limonite deposits. Possible economic value in future.

Sevierr, V., Analyses of Elba ore: Rassegna mineraria, vol. 14, pp. 101-102; Quoted and discussed by G. Martin in Oesterr. Zeitschr. Berg- u. Hüttenwesen, vol. 51, pp. 329-330, 1903.

Testa, L., The iron-ore deposits of Sardinia: Iron and Steel Inst. Jour., 1911, No. 2, pp. 364-379.

Good descriptive article. Needs a map. 
I A VAlle, G., On the iron-ore deposits of southern Italy and Sicily: Iron and Steel Inst. Jour., 1911, No. 2, pp. 409-411.

A purely geologic article.

"reivista del servizio minerario, 1913.

Official statistics.

JUGO-SLAVIA.

Beck, H., Lias bei Vares in Bosnien: K.-k. geol. Reichsanstalt Jahrb., vol. 53, pp. 473-480, 1903.

Discussion of paleontologic data in regard to the ore-bearing beds.

Hörhager, J., Das Erzrevier von Beslinac-Trgove in Croatien: Oesterr. Zeitschr. Berg- u. Hüttenwesen, vol. 51, pp. 87-90, 104-109, 1903.

Description of copper, lead, and zinc deposits. No reserves. Figures that it takes from 30,000 to 40,000 years to oxidize 1 meter of siderite.

Katzer, F., Die Eisenerzlagerstätten Bosniens und der Herzegowina: Berg- u. hüttenm. Jahrb., vol. 58, pp. 1-19, 1910.

Introduction gives historical data and shows primitive methods of industry. A complete study of many deposits, but only his brief article in "The iron-ore resources of the world" was used.

KrrTL, E., Geologie der Umgebung von Sarajevo, Bosnia: K.-k. geol. Reichsanstalt Jahrb., vol. 53, pp. 515-748, 1904.

Contains brief description of manganese deposits "am Ozren" and "bei Kulansoic."

Muzet, A. I., L'industrie minérale dans les Balkans: Soc. ind. min. Bull., vols. 14-15, pp. 113-151, 1911.

Serbia and Bulgaria. Maps showing ore deposits. Short description of deposits, laws, and general condition of industry.

Wendeborn, B. A., Die Kupfererz und Limonit Lagerstätten von Majdanpek: Zeitschr. prakt. Geologie, vol. 20, pp. 260-280, 1912.

Good description and history with a comprehensive bibliography.

\section{NORWAY.}

Everding, H., Reisebericht über eine Studienreise durch dir wichtigsten Erzgebiete Skandinaviens: Berg- u. hüttenm. Zeitung, vol. 62, pp. 3-10, 17-22, 33-36, 45-47, 57-60, 69-72, 1903.

Notes of a journey through Scandinavian mining districts. Contains some information on Sulitjelma and Dunderland.

Geijer, P., Contribution to the geology of the Sydvaranger iron-ore deposits: Geol. Foren. Stockholm Forh., 1911.

Geissed, H. L., The iron-ore deposits of Dunderland, Norway: Eng. News, vol. 43, pp. 276-277, 1900 .

Description with analyses and estimates of reserve and mining costs. Says that no less than $840,000,000$ tons may be available and that $200,000,000$ tons represent ore carrying from 55 to 65 per cent of iron.

Henrickson, G., The iron ores of Sydvaranger, Christiania, 1904.

Sundry geological problems, Christiania, 1906.

Geological notes, Christiania, 1910.

Discusses metamorphism.

LAUnAY, L. DE, L'origine et les caractères des gisements de fer scandinaves: Annales des mines, vol. 4, pp. 49-106, 109-211, 1903.

Description of geology of deposits and a theory of genesis as sedimentary deposits. 
Louis, H., Report to the Dunderland Iron Ore Co. (Ltd.), May 3, 1902: Iron and Steel Inst. Jour., 1902, No. 1. pp. 416-417 (abstract).

Gives some of the economic features of the Dunderland deposits.

Nicou, P., Étude sur les minerais de fer scandinaves: Annales des mines, vol. 19, pp. 85-174, 177-240, 249-378, 1911.

An extensive and thorough study of the mining, concentrating, and transportation of Swedish ores and descriptions of Swedish and Norwegian occurrences.

Srmmersbach, B., Die Eisenerzlagerstätten in Südvaranger, Finnmarken: Zeitschr.

Berg-, Hütten- u. Salinenwesen preuss. St., vol. 53, pp. 19-21, 1905.

A review of Henrickson's work. Gives good brief description.

Sjögren, H., The geological relations of the Scandinavian iron ores: Am. Inst. Min.

Eng. Trans., vol. 38, pp. 766-836, 1907.

An important contribution to the geology of the Scandinavian ores.

Smrth, H. H., Extensive iron-ore deposits, Trondhjem, Norway (Beitstaden-Aafjorden): Min. Jour., vol. 86, pp. 325-326, 1909.

A brief description with several analyses and a small map. Rather optimistic.

VoGт, J. H. L., Norges Jernnalinforekomster: Norges geol. Undersökelse, No. 51, pp. 1-225, 1910:

Iron-ore resources of Norway. Complete description in Norwegian. Basis for most of the estimates.

- Die regional-metamorphosierten Eisenerzlager im nördlichen Norwegen:

Zeitschr. prakt. Geologie, vol. 11, pp. 24-28, 59-65, 1903.

Description of Dunderland and Ofoten deposits. Considerable economics.

Development of theory that ores are original sedimentary deposits.

- Über den Export von Schwefelkies und Eisenerz aus Norwegischen Häfen:

Zeitschr. prakt. Geologie, vol. 12, pp. 1-7, 1904.

Über die Rödsand-Titaneisenerzlagerstätten in Norwegen: Zeitschr. prakt.

Geologie, vol. 18, pp. 59-67, 1910.

$A$ valuable contribution to the study of magmatic differentiation.

WENDEBoRn, B. A., Über die Eisenerzlagerstätten in Sydvaranger: Berg- u. hüttenm.

Zeitung, vol. 63, pp. 597-598, 1904.

Woodbridge, D. E., Mining and concentrating the Sydvaranger iron ores: Eng.

Mag., vol. 43, pp. 9-21, 1912.

A well-illustrated description of the Sydvaranger mining and milling methods.

- The Sydvaranger iron mines: Eng. and Min. Jour., vol. 92, pp. 260-264, 1911.

General descriptive article with pictures.

Norges Bergverksdrift, Kristiania, Det Statistiske Centralbyraa.

Official statistics. Annual.

The South Varanger iron-ore deposits, Norway: Engineering, vol. 93, p. 481, 1912.

Brief note on methods of working employed at Sydvaranger.

The South Varanger iron-ore deposits and separating and briquetting plants: Engineering, vol. 90, pp. 383-386, 1910.

Description of deposits and of installation of the machinery. Map.

POLAND.

Bartonec, F., Über die erzführenden Triasschichten Westgaliziens: Oesterr. Zeitschr.

Berg- u. Hüttenwesen, vol. 54, pp. 645-650, map, 1906.

Geologic article looking toward development of Austrian end of the Silesian mineral basin.

- Über die geologisch-montanistischen Verhältnisse des südöstlichen Teiles von

Polen: Oesterr. Zeitschr. Berg- u. Hüttenwesen, vol. 63, pp. 726-729, 1914.

An excellent article on the geology of southwestern Poland. 
Dobonzynski, S., [Iron ore in the Kielce district]: Geol. Centralbl., vol. 2, pp. 262, 686,1902 (abstract).

Brief review of article by Doborzynski on iron ore near Kielce, north of Olkusk. Deals mostly with genesis. Ore carries 40 to 50 per cent of iron. Occurs as "Klüftenfülling" in Jurassic.

Tretze, E., Die geognostischen Verhältnisse der Gegend von Krakau: K.-k. geol. Reichsanstalt Jahrb., vol. 37, p. 423, 1887.

Good geologic maps.

\section{PORTUGaL.}

[See Spain.]

\section{RUMANIA.}

Nopcsa, F., Zur Geologie der Gegend zwischen Gyulafehervar, Deva, Ruszkabanya und der rumänischen Landersgrenze: K.-ungar. geol. Anstalt Mitt. Jahrb., vol. 14, No. 4, pp. 93-276, 1905.

Geology of area in which lies the Hunyad district. Nothing about the ores except that they exist.

Paul, C. M., and Walther, B., Grundzüge der Geologie der Bukowina: K.-k. geol. Reichsanstalt Jahrb., No. 26, p. 261, 1876.

Geology and location of some iron deposits in Bukowina.

Poni, P., Études sur les minéraux de la Roumanie: Univ. Jassy Annales sci., vol. 1, pp. 15-148, 1901.

In describing minerals tells a little about their sources.

ScHÖPPE, W., Über kontaktmetamorphe Eisen-Mangan-Lagerstätten am Aranyos Flusz, Siebenbürgen: Zeitschr. prakt. Geologie, vol. 18, pp. 309-339, 1910.

A carefully worked out article on some unusual deposits, with a good discussion of the contact-metamorphic theories.

Weber, K. A., Der Eisenerzbergbau Ungarns: Glückauf, vol. 50, pp. 1193-1203, 1238-2149, 1914.

Brief description of larger Hungarian deposits, including the Hunyad and Banat, which now belong to Rumania.

\section{RUSSIA.}

GENERAL ARTICLES.

BALL, S. H., and Low, B., Metal mining in Russia: Eng. and Min. Jour., vol. 103, pp. 403-417, map, 1917.

General data on mining in Russia. Some statistics of production and much economic information. Place iron-ore reserve of Ural region at 135,000,000 tons. Give much data on ownership. Crimean reserves, $450,000,000$ tons, 40 per cent ore; Poland reserves, $300,000,000$ tons, 40 per cent ore.

Bogdanowitsch, K., Die Eisenerze Russlands: The iron-ore resources of the world (11th Internat. Geol. Cong.), vol. 1, pp. 363-544, Stockholm, 1910.

General review of the principal branches of the mining and metallurgical industries Petrograd, Gornago Department, 1915.

Source of statistics on Russian production.

King, C. R., Russia-its future as a coal and iron producer: Eng. Mag., vol. 48, pp. 481-492, 1915.

Review of situation in Russia, with a good many figures and an optimistic outlook for the future. Shows greatest familiarity with southern Russia.

Neumark, Dr., Die russische Kohlen- und Roheisen Industrie: Stahl und Eisen, vol. 21, pp. 62-68, 110-122, 1901.

An excellent review, with many statistical data. Particularly thorough in regard to southern Russia. 


\section{NORTHERN RUSSIA.}

Bogdanowitsch, K., Die Eisenerze Russlands: The iron-ore resources of the world (11th Internat. Geol. Cong.), vol. 1, pp. 516-518, Stockholm, 1910.

Schepowalnikoff, A., [The ore deposits of Lake Tulmo, Government of Olonetz]: Geol. Centralbl., vol. 3, p. 327, 1903 (abstract).

Iron ores are in veins several decimeters to 4 meters thick in silicified and dolomitized limestones.

- [Ore deposits of Tulomosersk district, Government of Olonetz]: Geol. Centralbl., vol. 2, p. 547, 1902 (abstract).

Very blef review. Hematite between dolomitized and silicified limestone.

CENTRAL RUSSIA.

Bogdanow, D., [Iron-ore deposits in Effremow district, Government of Tula]: Geoı. Centralbl., vol. 3, p. 6, 1903 (abstract).

Brief review. Deposits carry 38 to 55 per cent of iron. Metasomatic ferric hydrates on altered limestone along Tanj River.

BogdaNowitsch, K., op. cit., pp. 485-494.

Ennst, A., Die Kohlen und Eisenerzlagerstätten des centralen Russlands: Berg- u. hüttenm. Zeitung, No. 50, 1900.

Description of Moscow coal fields and iron ores of Tula-Jelez and Orel-Kromy.

Karakasch, N., [Some iron-ore deposits in the Shisdrink district, Government of Kaluga]: Geol. Centralbl., vol. 2, p. 136, 1902 (abstract).

On a deposit of brown ore and siderite in central Russia. Shows ore to be extensive but gives no idea of grade or thickness.

Koветzкі, J., [On Iwnian iron ore, Government of Kursk]: Geol. Centralbl., vol. 3, pp. 35-36, 1903 (abstract).

Deposits contain $380,000,000$ poods ( $6,220,000$ metric tons) ferric hydrates in 7 to 70 inch bed. Iron, 50 to 55 per cent; phosphorus, 0.4 to 0.68 per cent; sulphur, less than 0.28 per cent; manganese, up to 1.34 per cent.

Krasnopolsky, A., [Iron ore in Jeletsk district, Government of Orel]: Geol. Centralbl., vol. 3, p. 36, 1903 (abstract).

Brown ore in clay. Too low grade for much use.

Samojlow, J., [On the formation and paragenesis of the iron ores of central Russia]: Geol. Centralbl., vol. 1, p. 358, 1901 (abstract).

Review of Russian article.

\section{SOUTHERN RUSSIA.}

Bayard, M., Note sur les gisements de minerais de fer des presqu'îles de Kertch et de Taman: Annales des mines, 9th ser., vol. 15, pp. 505-522, 1899.

Historical and geologic note.

Besвorodкo, N., Ü̉ber eine neue Chromeisenerzlagerstätten am nördlichen Kaukasus und ihre mineralogischen Verhältnisse: Neues Jahrb., Beilage Band, vol. 34, pp. 783-798, 1912.

A mineralogic study of a serpentine-chromite-nickel deposit in southern Kuban area, 12 kilometers south of Psemjonowka.

Koвetzki, J., [On iron and coal of Iwanow, Government of Ekaterinoslaw]: Geol. Centralbl., vol. 3, p. $8,1903$.

Limonite interbedded with anthracite. Ore reserve over $1,000,000,000$ poods $(16,400,000$ metric tons). Iron, 46 to 61 per cent; sulphur, 0.08 to 0.3 per cent; lime, 0.2 to 2.2 per cent; insoluble, 5.3 to 32.9 per cent.

Monkofski, C., Krivoi Rog (partial translation by A. Foniakoff): Rev. univ. mines, vol. 12, pp. 72-105, 1905.

Pure geology. 
Piotrowski, L., [Iron ore in Don Basin]: Geol. Centralbl., vol. 3, p. 35, 1903 (abstract).

Ore consists of siderite "nests" in green gypsum-bearing clay. Hydrochemical ore formed by action of $\mathrm{FeSO}_{4}$ on limestone. No idea of extent.

Popov, S., Zeitschr. Kryst. Min., vol. 52, pp. 606-614, 1913.

A study of the minerals of the Kerch Peninsula.

Simmersbach, B., Die südrussischen Eisenerzfelder von'Krivoi Rog und Kertsch: Oesterr. Zeitschr. Berg- u. Hüttenwesen, vol. 62, pp. 253-257, 272-275, 288-291, 303-305, 1914.

Covers iron industry of entire country in introductory part. Very thorough study of Krivoi Rog with estimate of $55,160,000$ tons (based on Symanowski). Much less information on Kerch.

Sokolow, N., Iron ore in Pokrovsk property of Grand Duke Michael: Com. géol. Bull., vol. 19, pp. 407-421, 1900.

Brief résumé in French. Iron deposit at southwestern extremity of Government of Ekaterinoslav, at confluence of Bazalouk and Dnieper.

Szymanowskr, M., [Krivoi Rog iron-ore reserves]: Geol. Centralbl., vol. 3, p. 35, 1903 (abstract).

Figures Krivoi Rog at 3,500,000,000 poods (57,300,000 tons). Rubin gives review of Krivoi Rog literature.

Krivoi Rog: Soc. ind. min. Bull., 3d ser., vol. 14, pp. 1385-1459, 1900.

A complete detailed study. Contains bibliography. Figures reserves at $57,000,000$ tons of ore carrying about 60 per cent of iron.

Terpigorew, A., [Magnetite deposit of Daschkiessan, in the Caucasus]: Geol. Centralbl., vol. 3, p. 7, 1903 (abstract); Zeitschr. prakt. Geologie, vol. 13, pp. 116-117, 1905 (longer review, with sketches).

Estimates 5,000,000,000 poods (81,900,000 tons) in Daschkiessan, 900,000,000 poods (14,700,000 tons) in Gez-Dasch. Iron 62 to 68 per cent, silica 5 per cent, with much calcite. At 5 versts from these are unexplored deposits whose reserves probably equal "several milliard poods." The review in Zeitschr. prakt. Geologie ends by saying that these are the only reliable ("zuverlässige") deposits of iron ore in the Caucasus.

Thiess, F., Die Erzgruben von Krivoi Rog: Oesterr. Zeitschr. Berg.- u. Hüttenwesen, vol. 55, pp. $608-609,1907$.

Brief description, principally of industrial features, drawn from Russian sources.

Winda, - , [Iron ores of coast of Black Sea]: Geol. Centralbl., vol. 3, p. 36, 1903 (abstract).

Clay ironstone and brown ores. Abstract does not show what part of Black Sea coast is being discussed.

ZEIDLER, R., [Kerch iron ore district]: Geol. Centralbl., vol. 3, p. 5, 1903.

Gives reserve of $7,100,000,000$ poods (116,300,000 tons) and does not cover entire area.

The Russian iron industry and the Ukraine: Stahl und Eisen, No. 12, 1918; abstract in Chem. Industry, Feb. 28, 1919.

Krivoi Rog reserve 500,000,000 tons. Kerch reserve 500,000,000 tons. Donetz Basin and Kosak-Mogila of no importance. Other industrial data for 1912.

URAL REGION.

Bauermann, H., On the iron-ore deposits of the Ural: Iron and Steel Inst. Jour., 1898, No. 1, pp. 134-145.

Description of mining, with photographs and a plan of Bakal district.

Duparc, L., and Mrazec, L., Sur le minerai de fer de Troitsk (Oural du Nord): Compt. Rend., vol. 136, pp. 1409-1411, 1903.

Details of geology at Osamka mine at Troitsk, near Koswa. 
Fedorow, E., and Nikitin, W., [The Bogoslovski mining district]: Geol. Centralbl., vol. 2, pp. 326-327, 1902 (abstract).

The original is apparently a monograph on the geology and ore deposits of the district.

Koniouchevsky, L., [Geologic study in Bakalsk region]: Geol. Centralbl., vol. 4, p. 310, 1904 (abstract).

Fixes age of deposits in Devonian. No data on size given in abstract.

Geologic study of Zigaza and Komarovo iron deposits: Com. géol. Mém., No. 21, 1906 (Russian and French abstract).

Geologic study. Quotes estimate of 2,000,000 tons for Komaroskov district, 580,000 tons for Zigazinsky, and 180,000 tons for Bachkirsky.

Loewinson-Lessing, F., [On the magnetite deposit of Gora Blagodat]: Geol. Centralbl., vol. 12, p. 170, 1909 (abstract).

Geologic description.

[On the magnetite deposit of Wyssokaja, in the Ural region]: Geol. Centralbl., vol. 8, p. 411, 1906 (abstract).

A discussion of genesis. Concludes that ore is contact metamorphic.

Morozewicz, J., Die Eisenerzlagerstätten des Magnetberges (Magnitnaia Gora) im südlichen Ural und ihre Genesis: Min. pet. Mitt., vol. 23, pp. 113-152, 225-262, 1904; abstract in English in Inst. Min.-Eng. Trans., vol. 29, pp. 679-681; abstract in German in Zeitschr. prakt. Geologie, vol. 15, p. 90, 1907.

Very complete study, both petrographic and geologic. Interesting presentation of hydrothermal theory.

Mrazec, L., and Duparc, L., Über die Brauneisensteinlagerstätten des Bergreviers von Kisel im Ural (Kreis Solikamsk des permschen Gouvernements): Oesterr. Zeitschr. Berg- u. Hüttenwesen, vol. 51, pp. 711-715, 735-740, 1903.

Detailed descriptions of geology and mining.

Nikitrs, V., On the geology of Versk-Isetzk: Com. géol. Mém. 22, 1907 (Russian with French abstract).

Mostly geology and petrography (excellent photomicrographs), with a description of metalliferous deposits.

Ouspensky, L., [On Bogoslovski]: Geol. Centralbl., vol. 3, p. 36, 1903 (abstract).

Geologic data. Original article in Jour. des mines (Russian), No. 11, pp. 125-166, 1900.

Preston, T. H., The Urals and their mineral wealth: Min. Mag., vol. 14, pp. 197-201, map, 1916.

General and brief review, giving mostly historical and industrial data.

Shockley, W., The Bogoslovski mining estate: Am. Inst. Min. Eng. Trans., vol. 39, pp. 274-302, 1908.

General article. Estimated iron-ore reserve of $8,000,000$ tons hematite and limonite 30 to 66 per cent iron in basin deposits, 13 to 65 feet thick, 200 to 650 feet wide, 500 to 1,600 feet long. A bout 10,000 tons chrome iron ore mined since 1805 . Tables of weights and measures.

Smirnow, N., [Magnitnaia Gora of the Schaitanske district]: Geol. Centralbl., vol. 12, p. 171, 1909 (abstract).

Considers Magnitnaia as segregation of titaniferous magnetite from gabbroic magma. This is not the Magnitnaia Gora of the southern Ural region.

Terpigorew, A., [Distribution of iron ores of Ssulinskiron works]: Geol. Centralbl., vol. 3, p. 6, 1903 (abstract); Zeitschr. prakt. Geologie, vol. 13, p. 115, 1905 (better and longer review).

Iron ores are metasomatic ferric hydrates. Can not make estimate because of irregular nature of ore bodies. 
ZEmiatschensky, P., [On the genesis of some of the Ural ore deposits]: Geol. Centralbl., vol. 2, p. 685, 1902 (abstract).

Deals especially with the genesis of the metasomatic deposits in clay slates.

Jour. Chem. Ind., February 15, 1919, p. 47 R; from Zeitschr. Chemie, November 29, 1918.

Gives following estimates on reserves: Alapaievsk district-Sinitschihinske group, 400,000,000,000 poods (6,600,000,000 tons); Syrjanover group, 1,000,000,000,000 poods $(16,400,000,000$ tons); Alapaievsk group, 1,200,000,000,000 poods $(19,700,000,000$ tons). Average iron, 45 per cent. Deposits in Governments of Rjasan, Vladimir, and Nizhni Novgorod are extensive and of high metal content. Deposits at Lepesk in Government of Tambov are exceedingly valuable.

\section{SPAIN AND PORTUGAL.}

Adams, F. D., Notes on the iron-ore deposits of Bilbao: Canadian Min. Inst. Jour., vol. 4, pp. 196-204, 1901.

Good brief description with map and photographs.

Adaro, L. DE, and Junquera, G., Criaderos de hierro de Âsturias: Inst. geol. Mem., vol. 2, 1916.

One volume of text and one of maps. Part of a series of comprehensive and detailed articles on iron-ore deposits of Spain. De Adaro is the author, but owing to his death it was necessary for Junquera to revise the original for publication.

Amlburg, J., Die nutzbaren Mineralien Spaniens und Portugals: Zeitschr. prakt. Geologie, vo'. 15, pp. 183-210, 1907.

Good, fairly comprehensive article.

Brovgh, B. H., The iron-ore mines of Biscay: Cassier's Mag., vol. 23, pp. 697-709, 1902-3.

A well-written, carefully worked out semipopular article. Good photographs.

Bulmer, G. H., The Alquife iron-ore mines, in the south of Spain (Granada): Inst. Civil Eng. Proc., vol. 159, pp. 312-314, 1905.

Brief description, mostly of mining.

DANN, E., Die Eisenerzlager und die Eisenindustrie von Bilbao: Stahl und Eisen, vol. 33, pp. 1181-1185, 1232-1236, 1913.

Gives location and geology of the deposits and a review of past history. Forecasts a future of 15 to 20 years. Gives details of ore handling. Very good article.

FabreaA, P., A study of the iron-ore deposits of Almería, translated by C. V. Haines from Rev. minera, vol. 58, pp. 266-269, 284-288: Min. Jour., vol. 82, pp. 5, 44-45, 78-79, 114-115, 1907.

Written by a truly Spanish scholar, therefore it takes us from cosmogenesis to date. The translation is good. The economic and industrial part is clear. Estimates $50,000,000$ tons.

Frrcks, F., Über einige Lagerstätten der Provinz Almería in Spanien: Zeitschr. prakt. Geolgie, vol. 14, pp. 142-1.50, 233-236, 1906.

Contains short description of some of the iron deposits.

Grulman, F., Malaga magnetites: Inst. Min. Met. Trans., vol. 20, p. 447, 1911.

Interesting discussion of origin.

Gounot, A., Métallurgie du fer dans les Asturies: Soc. ind. min. Bull., 4th ser., vol. 3, pp. 749-783, 1904.

On Spanish metallurgy. Contains some descriptions of ore.

F 205, 1912.

An interesting geologic study. 
JонN, - - Die Eisenerzlagerstätten von Bilbao und ihre Bedeutung für die zukünftige Eisenerzversorgung Grossbritanniens und Deutschlands: Glückauf, vol. 46, pt. 2, pp. 2002-2013, 2045-2052, 1910.

A complete study with many sections and a map. Gives geography, geology, and study of reserves, as well as economic and statistical review and forecast. Reserve, $50,500,000$ tons. Says present production rate will last only 10 or 11 years, and suggests need of new source of similar ore for Great Britain and Germany.

Jones, J. A., Development and working of minerals in the Province of León, Spain: Inst. Min. Eng. Trans., vol. 20, pp. 420-441, 1901.

Pages $430-440$ contain a brief note on iron deposits.

The Devonian iron ores of Asturias: Inst. Min. Eng. Trans., vol. 18, pp. 279$292,1900$.

A study with analyses and descriptions of the formations. Appears to have been written by a stratigrapher rather than a man accustomed to mining geology. Kindelan, V., and Ranz, Manuel, Los criaderos de hierro de Guadalajara y Teruel: Inst. geol. Mem., vol. 3, 1918.

Detailed monograph with excellent maps. Part of series in course of publication, on Spanish iron ores.

Lozano, R. S., Datos geológico-mineros de la Provincia de Cáceres: Com. mapa geol. Bol., vol. 26, pp. 205-219, 1899.

Description of geology and mining.

Mackay-Heriot, E., The Bilbao iron mines: Eng. and Min. Jour., vol. 76, pp. 510 $512,1903$.

Description of deposits. Most emphasis on ore and method of occurrence. Some mining. Good general article.

Mallada, L., Datos geológico-mineros de varios criaderos de hierro de España: Com. mapa geol. Bol., vol. 26, pp. 152-203, 1899.

Description of some of the mines and ore deposits of Spain. Not so good as the recent work of the Spanish Survey.

McBride, H. A., Production of iron ore in Spain: Mines and Minerals, vol. 31, pp. 577-580, 1911.

A brief description of the iron-ore deposits of Spain and Portugal. Gives a complete set of figures for Spanish reserves.

Nicou, P., and Schuumberger, C., L'industrie minière et métallurgique dans les Asturies: Annales des mines, 10th ser., vol. 7, pp. 203-260, 1905.

Notes of a trip. Covers general geologic and geographic description of Oviedo and the coal and iron mining, with shorter discussion of metallurgic situation.

Pruz, R., Die Erzlagerstàten von Cartagena in Spanien: Zeitschr. prakt. Geologie, vol. 16, pp. 177-190, 1908.

Description of deposits of lead, zinc, and iron, with review of geology and of economic data.

Schmidr, C., and Preiswerk, H., Die Erzlagerstätten von Cala, Castillo de las Guardas, and Aznalcollar, in der Sierra Morena: Zeitschr. prakt. Geologie, vol. 12, pp. 225-238, 1904.

Geology of magnetite and pyrite deposits.

Simmersbach, B., Der Eisenerzreichtum Spaniens: Glückauf, vol. 41, pt. 2, pp. 1377-1382, 1905.

Gives distribution of deposits, analyses, and statistics of production.

Teicharäber, —- Eisenerzvorkommen in Galicien, Spanien: Stahl und Eisen, vol. 24, pp. 332-334, 1904.

A general and somewhat journalistic description of some deposits in Lugo.

Werneke, — Eisenerze im südlichen Portugal: Zeitṣchr. prakt. Geologie, vol. 10, pp. 151-152, 1902.

Brief geologic note on Villa de Frades deposits, in Alemtejo. 
Yarza, De R., Additional data on iron-ore reserves of southern Spain: Cong. géol. internat., $11^{\circ}$ sess.; Compt. rend., pp. 297-306, 1910.

YsASSI, V. DE (edited by A. S. Callen), The iron mines of the Sierra Menera district of Spain: Am. Inst. Min. Eng. Trans., vol. 53, pp. 84-89, 1915.

Descriptive article. Says more ore than present estimate of $1,00,000,000$ tons is to be expected.

Estadística minera de España (annually), Departamento de Fomento, Consejo de Mineria.

Official statistics.

\section{SPITZBERGEN.}

Conway, Sir Martin, The political status of Spitzbergen: Geog. Jour., London, vol. 53 , No. 2, p. 83.

Gives good historical review. H. G. Ponting in discussion speals of mineral wealth. Good iron ore near Recherche Bay (mountain several miles long and 1,500 feet high, "mostly" iron ore). Much good coal. W. S. Bruce in discussion says Gulf Stream keeps western and northern part warm all the year. Sir Aubrey Strahan, in further discussion, says the working of coal and iron mine would be difficult. Mentions report by G. C. Lloyd published by Department of Industrial and Scientific Research, 1917; 2d ed., 1918. Lloyd says none of the ironore deposits are good enough for profitable development. Högbom in 1914 says ore contains only 10 to 20 per cent of iron.

\section{SWEDEN.}

Äkerman, R., Outlines of the development of the Swedish iron industry: Iron and Steel Inst. Jour., pp. 7-35, No. 2, 1898.

A review with considerable statistical data.

ARLT, Hans, Geologie der Eisenerzlagerstätte von Kiruna und Gellivare: Glückauf, vol. 47 , pp. $765-777,1911$.

Account of trip of International Geological Congress in 1910. Excellent description of deposits and review of genetic theories. Gives reserves.

BärtuING, R., Die nordschwedischen Eisenerzlagerstätten: Zeitschr. prakt. Geologie, vol. 16, pp. 89-108, 1908.

Gives summary of export regulations. Many analyses, production, and reserve data. Good economic study.

Birkinbine, J., Scandinavian iron ores: Iron Age, vol. 85, pp. 986-987, 1910.

Brief general description.

DALY, R. A., Origin of the iron ores at Kiruna, Stockholm, 1915.

A contribution to the study of the genesis of the Kiruna ores.

Everding, H., Reisebericht über eine Studienreise durch die wichtigsten Erzgebiete Skandinaviens: Berg- u. huttenm. Zeitung, vol. 62, pp. 3-10, 17-22, 33-36, 45-47, 57-60, 69-72, 1903.

Pyrite deposits, Röros, Sulitjelma, Falun, central Sweden, Dunderland, Kongsberg. Not of any great importance so far as original material on iron is concerned.

Fermor, L. L., On the origin of the iron ores of Swedish Lapland: Iron and Steel Inst. Jour., 1911, No. 2, pp. 113-122.

A geologic discussion. Contribution to question of genesis.

Geijer, P. A., Igneous rocks and iron ores of Kirunavaara, Luosssavaara, and Tuollavaara, Stockholm, 1910.

Comprehensive and authoritative monograph with maps.

- Igneous rocks and iron ores of Kirunavaara, Luossavaara, and Tuollavaara:

Econ. Geology, vol. 5, pp. 699-718, 1910.

Author's abstract of monograph.

$15945^{\circ}-21-$ Bull. $706-10$ 
GerJer, P. A., Recent developments at Kiruna: Sveriges geol. Undersökning Årsbok 12 , pt. 5, 25 pp., 1918.

Geijer's latest contribution. On the strength of his most recent observations he changes his ideas and regards the ores as of intrusive origin.

- Studies on the geology of the iron ores of Lapland: Geol. Fören. Stockholm Förh., 1912.

Additional contribution to genetic discussion.

Guinchard, J., Sweden, 2d ed., 1914.

Historical and statistical handbook by order of Swedish Government.

Hecker, —- Bericht über eine im Sommer 1903 nach den Eisenerzvorkommen an des Ofotenbahn ausgeführte Studienreise: Zeitschr. Berg-, Hütten- u. Salinenwesen preuss. St., vol. 52, pp. 61-85, 1904.

General descriptive article, well illustrated.

Herdsman, W. H., On the organic origin of the sedimentary ores of iron and of their metamorphosed forms, the phosphoric magnetites: Iron and Steel Inst. Jour., 1911, No. 1, p. 476.

Illustrates extreme application of a man's pet theory.

Нӧявом, A. G., The Gellivare iron mountain: Cong. géol. internat., $11^{\mathrm{c}}$ sess., Guide des excursions, No. 4, 1910.

Description and geology. Maps and sections.

JoHansson, H. E., The Grängesberg iron ores: Idem, No. 32, 1910.

Description and geology. Maps and sections.

The Flogberget iron mines: Idem, No. 30, 1910.

Description and geology. Maps and sections.

KuкUк, - Die mittelschwedischen Erzlagerstätten: Glückauf, vol, 47, pt. 1, pp. 820-827, 861-870, 905-914, 1911.

Account of International Geologic Congress trip in 1910. Excellent presentation of geology. Also gives reserves and some mining.

LAUNAY, L. DE, L'origine et les caractères des gisements de fer scandinaves: Annales des mines, vol. 4, pp. 49-106, 109-211, 1903. .

Description of geology of deposits and advancement of the theory that they are metamorphosed sediments.

Lundвонm, H., On the iron-ore deposits of Kirunavaara and Luossavara: Iron and Steel Inst. Jour., 1898, No. 2, pp. 111-130, map.

Description of the deposits.

Sketch of the geology of the Kiruna district: Cong. géol. internat., $11^{\mathrm{e}}$ sess., Guide des excursions, No. 5, 1910.

Description and geology; maps and sections.

Miluer, W. G., Eleventh International Geological Congress, Sweden, 1910: Canadian Min. Jour., vol. 31, pp. 591-598, 1910.

General description of deposits visited.

Nicou, P., Étude sur les minerais de fer scandinaves: Annales des mines, vol. 19, pp. 85-174, 174-240, 249-378, 1911.

An extensive and thorough study of the mining, concentrating, and transportation of Swedish ores and description of Swedish and Norwegian deposits.

Nondenström, G., The most prominent and characteristic features of Swedish iron mịning: Iron and Steel Inst. Jour., 1898, No. 2, pp. 35-76, map.

Excellent general description of occurrences and methods of prospecting and mining.

Osbonn, C. S., Iron ores of Arctic Lapland: Lake Superior Min. Inst. Jour., vol. 9, pp. 94-113, 1903.

A summary of Lundbohm's report. Maps of Gellivare and Kirunavaara. 
Peterson, H., Über die Eisenerze Lapplands: Oesterr. Zeitschr. Berg- u. Hüttenwesen, vol. 51, pp. 742-743, 1903.

Summary of a Swedish paper. Describes ores and comments on magnetometric surveys.

Petersson, W., Die Erzfelder von Norberg: Cong. géol. internat., $11^{\circ}$ sess., Guide des excursions, No. 29, 1910.

Description, analyses, and map.

SJöGren, H., The Längban mining field: Cong. géol. internat., $11^{\circ}$ sess., Guide des excursions, No. 33, 1910.

Description and geology. Maps and sections.

The Persberg mining field: Idem, No. 34, 1910.

Description and geology. Maps and sections.

Spackeler, - - Schwedens Eisensteinbergbau: Glückauf, vol. 45, pp. 473-481, 509-515, 545-550, 594-603, 632-638, 669-672, 1909.

Full title is "Sweden's iron-ore mining from technical, social, and industrial viewpoint, its future and development." A thorough study from a German viewpoint.

Stutzer, 0., Die Eisenerzlagerstätten "Gellivare" in Nordschweden: Zeitschr. prakt. Geologie, vol. 14, pp. 137-140, 1906.

Discussion of geology concluding that Gellivare is a metamorphosed Kirunavaara.

Die Eisenerzlagerstätten bei Kiruna: Zeitschr. prakt. Geologie, vol. 14, pp. 65-71, 140-142, 1906.

Contribution to discussion of origin. Very strong argument in favor of magmatic differentiation. Good references and brief review of other theories.

The geology and origin of the Lapland iron ores: Iron and Steel Inst. Jour., 1907, No. 2, pp. 106-207.

Comprehensive article with excellent maps and sections. An English edition of the author's studies which have appeared in various German publications. Has good bibliography.

Wrikinson, W. F., Iron-ore mining in Scandinavia: Inst. Min. Met. Trans., vol. 13, pp. 489-508, 1904.

Description as results of a brief visit, with particular interest in problems of transportation.

Winchelt, H. V., Swedish mines and mining: Min. and Sci. Press, vol. 102, pp. 35-38, 1911.

General article. Considerable historical information.

Woodbridge, D. E., Iron mining in Scandinavia: Eng. and Min. Jour., vol. 91, pp. 1255-1260, 1911.

Good general article.

Zsigmondy, A., Über den schwedischen Eisenerzbergbau: Oesterr. Zeitschr. Berg- u. Hüttenwesen, vol. 51, pp. 279-285, 300-303, 1903.

Description of mines from observations made on a brief trip.

Bergshantering, Sveriges Officiella Statistik, Stockholm, Kommers Kollegium.

Official statistics, published annually.

\section{SWITZERLAND.}

Fleury, E., Le fer et le terrain sidérolithique dans le Jura bernois: Soc. fribourgeoise sci. nat. Bull., vol. 12, pp. 29-33, 1904; abstract in Inst. Min. Eng. Trans., vol. 29, pp. 690-691, 1905.

Pisolitic iron ores at base of upper Eocene. Interstratified. 60 per cent ferric oxide, 13 per cent silica, 15 per cent alumina. 
Herm, A., Über die Erze des Avers und Oberhalbsteintal in Graubinden: Geol. Centralbl., vol. 1, p. 740, 1901 (abstract).

Old siderite workings. Insufficient quantity for exploitation. Irregular hematite lenses in Triassic marble; never pay to work. Manganese ore; good but not enough to pay.

Helbling, R., [Mont Chemin ore deposits]: Oesterr. Zeitschr. Berg- u. Hüttenwesen, vol. 51, p. 169, 1903 (abstract).

Geology.

Hотz, W., Die Lagerstätten der nutzbaren Mineralien in der Schweiz: Zeitschr. prakt. Geologie, vol. 17, pp. 29-42, map, 1909.

Gives reserve figures. Total less than 2,500,000 tons of iron.

Sснмidт, C., Mining in Canton Wallis: Zeitschr. prakt. Geologie, vol. 11, pp. 205-208, 1903.

From 300,000 to 400,000 cubic meters of 30 per cent ore near Chamoson. Hematite, magnetite, and iron silicate. Mont Chemin, 100,000 cubic meters of 50 per cent iron ore. Simplon Pass, magnetite in small bodies in limestone.

Wencélius, A., Eisen and Manganerzgruben der Schweiz: Berg- u. hüttenm. Zeitung, vol. 62, pp. 541-545, 629-631; vol. 63, pp. 217-219, 1903.

Most comprehensive review of following deposits: ${ }^{\circ G o n z e n, ~ 1,500,000 ~ m e t r i c ~}$ tons ore, 800,000 metric tons iron; Erzegg, minimum 842,000 metric tons iron; probable, 2,456,000 metric tons iron; possible, 4,854,000 metric tons iron; Planplatten, 68,000 tons iron probable; Delsberg, can not be estimated.

\section{TURKEY.}

Dominian, L., Mining in Turkey: Eng. and Min. Jour., vol. 78, pp. 184-186, 1904. General article.

NotTmeyer, Max, Die Eisenvorräte der Turkei: The iron-ore resources of the world (11th Internat. Geol. Cong.), vol. 1, pp. 352-353, Stockholm, 1910.

\section{UNITED KINGDOM.}

Department of Scientific and Industrial Research, Advisory Council, Report on the sources and production of iron [etc.], pp. 1-37, London, 1918.

A revision of the information contained in "The iron-ore resources of the world," with later data.

JùnGST, E., Eisenerzversorgung Grossbritanniens: Glückauf, January 8, 1915, p. 42. Many tables. Good discussion.

Louis, HenRy, The iron-ore resources of the United Kingdom of Great Britain and Ireland: The iron-ore resources of the world (11.th Internat. Geol. Cong.), vol. 2, pp. 623-641, Stockholm, 1910.

Excellent summary of the British resources as seen by the geologist.

Summary of progress of the Geological Survey of Great Britain, London, pp. 6-7, 1917. Used for data on reserve.

Mines and Quarries (blue book).

Official statistics, published annually. 


\section{INDEX.}

A.

Acknowledgments for aid.

Alava Province, Spain, deposit in ............ 3

Albania, deposits in.................... 115

Alemtejo Province, Portugal, deposits in.... 44

Almería Province, Spain, deposits in ........ 39-40

Anjou, France, deposits in.

deposits in, map showing.

Armorican Peninsula. Sce Anjou, Brittany, and Normandy.

Asia, resources of ....................... 30

Austria, production and consumption by.... 104 resources of......................... 102-104

bibliography of................ 126-127 map showing................ In pocket.

Austro-Hungarian Empire, production and consumption in............ 105-109

resources of.................. 107

B.

Badajoz. Province, Spain, deposits in........ Balkan States, map of, showing ore reserves................... In pocket.

Banat district, Rumania, deposits in . .... 112-113

Bavaria, deposits in ..................... 83 84

Belgium, production and consumption by... $\quad 74$ resources of........................... 72-74

bibliography of................. 127 map showing............... In pocket.

Bentheim region, Germany, deposits in..... 80-81 Bergischer district, Germany, deposits in .... 76-77

Bibliography........................ 124-148

Bilbao, Spain, deposits near . ............. 33-34

Blast furnaces, low output of.............. 27-28

Bliss, Eleanora F., acknowledgment to...... 17

Bog ores, distribution of................... 24 origin of ............................. 14, 15

Bohemia, Czecho-Slovakia, deposits in..... 104-105 deposits in, map showing............. 104

Bosnia, Jugo-Slavia, deposits in........... 115

Brembana Valley, Italy, deposits in........ 90

British Isles, map of, showing ore resources.................... In pocket.

Brittany, France, deposits in.............. 66 deposits in, map showing............... 64

Bukowina, Rumania, deposits in........... 113

Bulgaria, resources of................... 109-110 reseurces of, hibliography of.......... 127

c.

Cáceres Province, Spain, deposit in

Campine region, Belgium, deposits in
Carboniferous sedimentary ores, distribution

of . ...................... 23, 48-49

Caucasus region, Russia, deposits in ....... 1i $8-119$

Chamosite, composition of................ 13

Charcoal, decreasing use of.................. 16

Cost of production, factors in ............ 27-29

Christiania district, Norway, deposits in.... 92,94

Chromiferous ores, occurrence of .......... 24,110

Cleveland district, England, deposits in..... 45-46

Coal, coking, dependence of iron industry on.. 15-

16,29

in Belgium .................... 74

in Czecho-Slovakia................ 107

in France........................ 71

in Moravia....................... 105

in the United Kingdom........... 55

Composition of iron-bearing minerals....... 13

Consumption, conditions affecting .......... 26-29

percentage of, by countries............. 25

See also Production and consumption under the several countrics.

Continents, resources of, compared......... 29-31

Countries, rank of, in ownership of iron

resources.................... 18-22

Cordillera, Cantabrian, deposits in......... 31-34

Cornwall, England, deposits in ........... 50

Cretaceous sedimentary ores, distribution of.. 24

Croatia, Jugo-Slavia, deposits in........... 114

Cumberland, England, deposits in......... 49

Czecho-Slovakia, deposits acquired by ....... 17

production and consumption by......... 107

resources of....................... 104-107

bibliography of ................... 127-128

map showing................ In pocket.

D.

Definitions of terms...................... 12

Denmark, map of .................... In pocket. Deposits formed by igneous agencies, origin of. 13-14 Deposits formed by surficial agencies, origin

of............................ 14-15

Devon, England, deposits in............. $\quad 50$

Devonian sedimentary ores, distribution of .. 23

Dielette, France, deposits at.............. 65

Dill district, Germany, deposits in......... 77-78

deposits in, map showing.............. $\quad 78$

Distribution, geographic, summary of........ 17-22

geologic, summary of . ............... 22-24

E.

Ebro River, Spain, deposits west of......... 35-36

Elba, deposits on...................... $\quad 89$ 
Page.

Electro-metallurgy, increasing use of...... 16,91, 99 England. See United Kingdom.

Erzberg, Austria, deposits near ........... 102-103 Esthonia, map of .................. In pocket possibility of ore in .................. 101

Europe, map of, showing ore resources.. In pocket. Exports of ore, proportion of, to consumption. 26-27

\section{F.}

Finland, consumption by ............... 100 resources of. ......

bibliography of .................. 128 map showing................ In pocket.

Flux, distribution of..................... 16

France, commercial policy for ............. 71-72

consumption by ...................... 70

deposits acquired by ................. 17

minor deposits in ...................... $68-69$

production in........................ $69-72$

resources of.......................... 55-72

bibliography of................ 128-131

map showing................ In pocket.

rank in......................... 18

Future of the iron industry ............... $\quad 29$

\section{G.}

Gabbros, iron ores associated with

Geology of iron ores, bibliography of

Germany, consumption by.............. 84-87 importance of Lorraine ores to........... 58 north and central, deposits of........... 82 production by........................ 84-87 resources of......................... $75-87$ bibliography of................. 131-1.35 map showing............... In pocket. rankin......................... 18,21

Gerona Province, Spain, deposits in ....... 35

Glauconite, composition of .............. 13

Gloucester, England, deposits in............ 51

Goethite, composition of.................. 13

Grängesberg, Sweden, ore field at........... 96

Granada Province, Spain, deposits in....... 39

Granitic rocks, iron ores associated with ..... 14, 15

Great Britain. ' See United Kingdom.

Greece, resources of ...................... 110-111

resources of, bibliography oi............. 135

map showing ................ In pocket.

Guadalajara Provinre, Spain, deposits in .... 36-37

Guipuzcoa Province, Spain, deposits in..... 34-35

\section{H.}

Harz Mountains, Germany, deposits in...... Haute-Marne Department, France, deposits

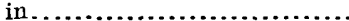

Hematite, composition of.................... Herzegovina, Jugo-Slavia, deposits in........ Hesse, Lower, Germany, deposits in......... Holland. See Netherlands.

Huelva Province, Spain, deposits in.........

Huesca Province, Spain, deposits in........

Hungary, deposits in.................... 107 deposits in, map showing.......... In pocket. Hunyad district, Rumania, deposits in .... 112-113 Hüttenberg district, Austria, deposits in .. 102-103
I.

Page.

Igneous rocks, iron ores in. ............13-14, 15 Imports of ore, proportion of, to consumption. $\quad 27$ Inverness, Scotland, deposits in........... 48 Ireland, deposits in..................... 51

Iselde region, Germany, deposits in......... 79

Italy, central, deposits in ................ 90 production and consumption by........ 91 resources of......................... 89-91 bibliography of.................. 135-137 map showing................ In pocket.

J.

Jaén Province, Spain, deposits in........... 38

Jugo-Slavia, deposits acquired by............ 17 resources of....................... 113-115 bibliography of ................. 137 map showing................ In pocket. Jura Mountains, Switzerland, deposits in.... 87-88 Jurassic sedimentary ores, locations of ....... 23-24

$\mathrm{K}$.

Kalkberg district, Germany, deposits in..... 76-77 Kellerwald region, Germany, deposits in..... $\quad 80$ Kent, England, deposits in............... 51

Kerch, Russia, deposits in................ 118

Known ore, definition of.................. 12

Krivoi Rog, Russia, deposits in........... 117

\section{L.}

Labor, cheapness of..................... 28-29

Lahn district, Germany, deposits in ........ 77-78 deposits in, map showing.............. 78

Lake Superior district, United States, production in .................... 58

Lancaster, England, deposits in ............ 49

Lapland, Swedish, deposits in............ 95-96

Latvia, map of ..................... In pocket. possibility of ore in................... 101

Leicester, England, deposits in ............ 47

Leon Province, Spain, deposits in.......... 32

Lerida Province, Spain, deposits in......... 35

Liége district, Belgium, deposits in......... 73

Limitations of the report . ............... 11-12

Limonite, composition of ................ 13

Lincoln, England, deposits in............. 46-47 deposits in, map showing.............. 48

Lithuania, map of.................... In pocket. possibility of ore in ................. 101

Lofoten Islands, Norway, deposits on........ 93.

Logroño Province, Spain, deposits of....... 35 .

Lorraine Annexée, consumption in......... 85. production in................... 56-57, 85,86 .

Lorraine, French, deposits in.............60-63

Lorraine, France and Germany, production in ............................ 55-59 resources of.........................6 63-64

Lugo Province, Spain, deposits in.......... 31

Luxemburg, deposits in............. 61, 74-75 production in.................... 56,75,86

M.

Magnetite, composition of ................ 13 deep-seated, distribution of............... 24 mode of occurrence of.................. 14 
Malaga Province, Spain, deposits in. ........ Map of the ironstone districts of Northampton and Lincoln, England.......

Map showing distribution of oolitic iron ores in Normandy, Brittany, and Anjou, France................ siderite deposits of Siegerland, Germany.. resources of iron in Austria, Hungary, and Czecho-Slovakia........ In pocket. in Bohemia....................... 104 in Europe................... In pocket.

in Finland, Poland, west-central Russia, Esthonia, Latvia, and Lithuania................ In pocket.

in France, Belgium, and Netherlands.................... In pocket. in Germany and Switzerland... In pocket. in Italy .................. In pocket. in Norway, Sweden, and Denmark.................... In pocket. in Portugal .................. In pocket.

in Russia, central.............. In pocket. northern................. In pocket. southern................. In pocket.

in Spain ..................... In pocket.

in the Balkan States........... In pocket.

in the British Isles............. In pocket.

in the Lahn-Dill district, Germany........................

in Vizcaya Province, Spain......... 34 Mesozoic ores, distribution of, in Great Britain........................ $45-48$

Minerals, iron, composition of.............. 13

Minette ores, bedding of ................... 62

composition of ....................... 61,62

value of........................... 62

See also Lorraine and Luxemburg.

Mining, output per man in............... 27

Moncorvo, Portugal, deposits near......... 42-43 Moravia, deposits in..................... 105

Murcia Province, Spain, deposits in......... 40

\section{N.}

Namur district, Belgium, deposits in...... 73 Navarra Province, Spain, deposits in...., ... 34-35 Netherlands, iron ore and coal in........... 74 map of....................... In pocket. Normandy, France, deposits in...........64-65 deposits in, map showing.............. 64

North America, resources of ............. 29-30

Northampton, England, deposits in........ 48 deposits in, map showing.............. 48

Norway, ores of, nature and origin of..... 91-92,93 resources of......................... 91-94 bibliography of................. 137-138 map showing............... In pocket.

\section{o.}

Oceania, resources of ...................... Ochtrup region, Germany, deposits in....... 80-81 Odemira, Portugal, deposits near........... 44 Ordovician sedimentary ores, distribution of. $\quad 23$ Ore, definition of ......................... 12

Origin of iron ores...................... 13-15 Ottenstein region, Germany, deposits in .... 80-81 Oviedo Province, Spain, deposits in
Ownership of iron deposits, changes in...... 17-18 Oxford, England, deposits in............. 47

\section{P.}

Percentage of iron resources, by countries.... 18-22 Phosphorus, content of, in ores of Belgium... 72,73 content of, in ores of Czecho-Slovakia.. 194,106 in ores of Finland............... 100 in ores of Italy .................... 89,90 in ores of Russia............ 118, 119, 120 in ores of Sweden................96,98 in ores of the Woser district, Germany $\quad 79$ influence of, on Lorraine ores........ 55-56,62 low, ores, distribution of............... 24 Pliocene sedimentary ores, distribution of ... 24 Poland, deposits acquired by .............. 17, 18 production in....................... 102 resources of........................ 101-102

bibliography of ................ 13\&-139 map showing............... In pocket.

Political divisions, changes in............ 17-18

Porto de Moz, Portugal, deposits at......... 44

Portugal, production of.................. $\quad 45$ resources of.......................... 42-45 bibliography of ................ 143-145 map showing................. In pocket.

Possible ore, definition of .................. 12 Pre-Cambrian sedimentary ores, distribution of. ........................ 22-23

Probable ore, definition of ................ 12

Production, cost of..................... 27-29 percentage of, by countries............ 25 See also Production and consumption under the several countries.

"Purple ore," occurrence of. ................ 24, 93 Pyrenees Mountains, deposits in........... $34-35$ Pyrénées-Orientales Province, France, ores of...................... $66-67$ R.

Replacement deposits, distribution of...... $\quad 24$ origin of ............................. 14, 15

Rhine, deposits west of ................. 76

Roumania, deposits acquired by........... 17 resources of ....................... 111-113 bibliography of .................. 139

Russia, central, map showing deposits in. In pocket. central, rank of ...................... 18, 21 geographical divisions of.............. 18 northern, map showing deposits in. In pocket. southern, map showing deposits in. In pocket. production and consumption in........ 123 resources of......................... 116-123 bibliography of ................. 130-143 rank of ......................... 21 west - central, map showing deposits in

In pocket.

Ruthenia, Czecho-Slovakia, deposits in.... 105-107 Rutland, England, deposits in............ 47

\section{S.}

Saar Valley, Germany, iron minerals in.... 75 Salzgitter region, Germany, deposits in...... 79 Santander Province, Spain, deposits in ..... 32-33 São Thiago de Cacem, Portugal, deposits near $\quad 44$ 
Saragossa Province, Spain, deposits in Page.

Sardinia, deposits on

Sauerland region, Germany, deposits in....

Schmiedeberg, Germany, deposit at.......

Scope of the report.

$11,16-17$

Sedimentary formations, iron ores in.... . 13, 14-15

Serbia, Jugo-Slavia, deposits in............. 114

Serra dos Monges, Portugal, deposits in..... 44

Seville Province, Spain, deposits in........ 38

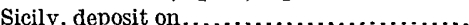

Siderite, composition of.................

Siegerland district, Germany, deposits in ....

deposits in, map showing.

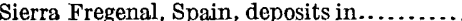

Sierra Guadalupe, Spain, deposit in.........

Sierra Menera, Spain, deposits in.......... 36-37

Sierra Morena, Spain, deposits in........... 37-39

Silesia, Germany, deposit in ............. 84

Silurian sedimentary ores, distribution of.... 23

Slavonia, Jugo-Slavia, deposits in.......... 114

Somerset, England, deposits in........... 51

Soria Province, Spain, deposits in.......... 35

Sources of information. .............. 9, 11, 17

South America, resources of............. $\quad 30$

Spain, consumption by.................

production by $\ldots \ldots \ldots \ldots \ldots \ldots \ldots \ldots \ldots \ldots .41-42$

resources of......................... 31-40

bibliography of................ 143-145

map showtng............... In pocket.

rank of ........................... 18, 21

Spencer, A. C., acknowledgment to........ 17

Spessart, Germany, deposits at............ 78

Spitzbergen, deposits on................ 55

deposits on, bibliography of ............. 145

Summary of the report................ 17-31

Sweden, production and consumption by.... 99

resources of. ....................... 94-99

bibliography of .............. 145-147

map showing............... In pocket.

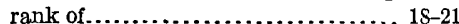

titaniferous ores of ................ 96,98

Switzerland, resources of............... 87-89

resources of, bibliography of........... 147-148

map showing ............ In pocket.

Sydvaranger, Norway, deposits in........ 92,93
$\mathrm{T}$

Page.

Taberg, Sweden, deposits at............. 98

Taunus Hills, Germany, deposits in....... 78

Terms, definitions of . ................... 12

Teruel Province, Spain, deposits in........ 36-37

Teutoburger Wald, Germany, deposits in.... 81

Thuringia, Germany, deposits in . ......... 82-83

Titanium, occurrence of, in iron ores........ 12 ,

$14,24,93,96,98,121$

Ton, metric, use of . .................. 12

Transportation, relation of, to cost of production...................... 28

Turkey, deposits in.................... 115

deposits in, bibliography of.......... $\quad 148$

U.

Umpleby, Joseph B., acknowledgment to... 17 preface by ..................... 9

United Kingdom, consumption by........ 52-55 production by ................... 52-55

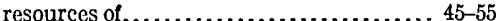

bibliography of................. 148

map showing................. In pocket.

rank in ....................... 18-21

summary of . ................... 52

Ural Mountain region, Russia, deposits in. 119-122

Uses of knowledge of foreign mineraldeposits. $\quad 9$

Utilization of iron ores, materials needed for. . 15-16

\section{$\mathrm{V}$}

Vald'Aosta, Italy, deposits of ........... 90

Vein deposits, distribution of.............. 24

Vidal, L. M., cited....................... 33

Vizcaya Province, Spain deposits in....... 33-34

deposits in, map showing........... In pocket.

Vogelsberg Hills, Germany, deposits in..... 78

W.

Wales, resources of . ............... 48-49,51

War, World, relation of Lorraine ores to.... 58

Weser district, Germany, deposits in ....... 79-82

Wesergebirge, Germany, deposits in....... 81

Westerwald district, Germany, deposits in.. $\quad 78$

Wilts, England, deposits in............... 51

World, resources of .................... 30-31

Württemberg, Germany, deposits in....... 83-84 